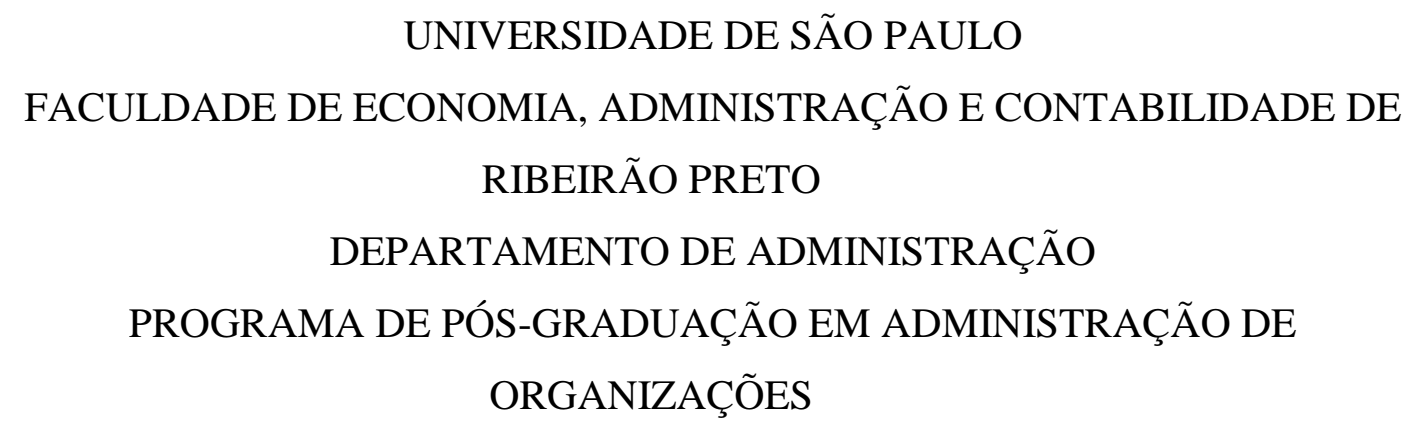

Larissa Mayer Munhos

Diagnóstico da experiência de produtores de cana-de-açúcar do interior de São Paulo na perspectiva do ecossistema do cliente

ORIENTADOR: PROF. DR. MARCOS FAVA NEVES

RIBEIRÃO PRETO

2019 
Prof. Dr. Vahan Agopyan

Reitor da Universidade de São Paulo

Prof. Dr. André Lucirton Costa

Diretor da Faculdade de Administração, Economia e Contabilidade de Ribeirão Preto

Prof. Dr. Jorge Henrique Caldeira de Oliveira

Chefe do Departamento de Administração

Prof. Dr. João Luiz Passador

Coordenador do Programa de Pós-Graduação em Administração de Organizações 
Larissa Mayer Munhos

Diagnóstico da experiência de produtores de cana-de-açúcar do interior de São

Paulo na perspectiva do ecossistema do cliente

Dissertação apresentada ao Programa de PósGraduação em Administração de Organizações da Faculdade de Economia, Administração e Contabilidade de Ribeirão Preto da Universidade de São Paulo para obtenção do título de Mestre em Ciências. Versão Original.

ORIENTADOR: PROF. DR. MARCOS FAVA NEVES

\section{RIBEIRÃO PRETO}


Autorizo a reprodução e divulgação total ou parcial deste trabalho, por qualquer meio convencional ou eletrônico, para fins de estudo e pesquisa, desde que citada a fonte.

\section{Catalogação da publicação}

Faculdade de Economia, Administração e Contabilidade de Ribeirão Preto, Universidade de São Paulo

FICHA CATALOGRÁFICA

Munhos, Larissa Mayer

Diagnóstico da experiência de produtores de cana-de-açúcar do interior de São Paulo na perspectiva do ecossistema do cliente. Ribeirão Preto, 2019.

197 p. il.

Dissertação de Mestrado apresentada à Faculdade de Economia, Administração e Contabilidade de Ribeirão Preto / USP.

Área de Concentração: Marketing Organizacional

Orientador: Prof. Doutor Marcos Fava Neves

1. Diagnóstico da experiência do cliente. 3. Perspectiva do ecossistema do cliente 3 . Produtor de cana-de-açúcar 
MUNHOS, L. M. Diagnóstico da experiência de produtores de cana-de-açúcar do interior de São Paulo na perspectiva do ecossistema do cliente. 2019. 196 f. Dissertação (Mestrado em Ciências) - Faculdade de Economia, Administração e Contabilidade de Ribeirão Preto, Universidade de São Paulo, Ribeirão Preto, São Paulo, 2019.

Aprovado em:

\section{Banca Examinadora}

Prof. Dr.

Instituição:

Assinatura:

Prof. Dr.

Instituição:

Assinatura:

Prof. Dr.

Instituição:

Assinatura: 


\section{AGRADECIMENTOS}

Ao meu marido Alexandre, por todo amor, incentivo, apoio e compreensão. Obrigada por ser a minha fonte de equilíbrio, força e motivação.

Ao meu filho Matias, pelo amor e pela energia que me inspiraram. Obrigada pelas horas abdicadas da minha presença, em tão tenra idade.

Aos meus pais, pela educação e pelos valores que me trouxeram até aqui. Obrigada por não terem medido esforços para me proporcionar uma formação excelente.

Ao meu orientador Prof. Dr. Marcos Fava Neves, pela oportunidade de aprendizado e crescimento. Obrigada pelos direcionamentos e por ser uma referência como profissional, sempre compartilhando conhecimentos e experiências.

Aos produtores de cana-de-açúcar entrevistados, pela disposição e entusiasmo ao contribuir com suas experiências.

As organizações Orplana e Socicana pela disponibilidade em participar desta tese.

Ao gestor executivo da Orplana, Celso Albano de Carvalho, pelas inúmeras conversas e compartilhamento de conhecimentos, fundamentais para a construção deste trabalho.

Ao gestor executivo da Socicana, Rafael Bordonal Kalaki, pela colaboração com a pesquisa e pelas excelentes contribuições para o desenvolvimento do trabalho.

Aos membros da banca pelas orientações e pelas contribuições.

A Universidade de São Paulo e Faculdade de Economia, Administração e Contabilidade de Ribeirão Preto, pela oportunidade e conhecimento.

Aos professores e colegas do Programa de Pós-Graduação em Administração de Organizações pelo compartilhamento de conhecimentos e experiências, que foram extremamente importantes nesta jornada de aprendizado.

Aos funcionários do Departamento de Pós-Graduação em Administração de Organizações pela disponibilidade e apoio.

A Coordenação de Aperfeiçoamento de Pessoal de Nível Superior (CAPES) pela concessão da bolsa de mestrado, auxiliando financeiramente parte deste estudo.

Finalizo destacando que, sem todas estas interações e trocas humanas, esta jornada não teria me proporcionado tamanho aprendizado e crescimento. 


\section{RESUMO}

MUNHOS, L. M. Diagnóstico da experiência de produtores de cana-de-açúcar do interior de São Paulo sob a perspectiva do ecossistema do cliente. 2019. 196 f. Dissertação (Mestrado em Ciências) - Faculdade de Economia, Administração e Contabilidade de Ribeirão Preto, Universidade de São Paulo, Ribeirão Preto, São Paulo, 2019.

A heterogeneidade do mundo dos produtores de cana-de-açúcar, em seus diferentes níveis de profissionalização e gestão, pode revelar caminhos para elevar a eficiência do setor. Este estudo visa complementar os esforços da Orplana, Organização dos Produtores de Cana-de-Açúcar da Região Centro-Sul do Brasil, para compreender as distintas realidades dos produtores de canade-açúcar e obter um ganho de inteligência para o setor. $\mathrm{O}$ objetivo da pesquisa foi mapear as experiências de produtores de distintos portes e níveis de verticalização na perspectiva do seu ecossistema, identificando oportunidades para os agentes do setor, incluindo os próprios produtores, repensarem suas ações e suas interações, visando melhorar a competitividade da cadeia sucroenergética. A metodologia adotada envolveu técnicas de pesquisa qualitativas e diagramas de visualização para mapear as percepções e as interações dos produtores ao longo dos processos que realizam para alcançar seus objetivos. A técnica de construção de personas foi utilizada para representar as experiências de produtores de três diferentes perfis. As oportunidades foram identificadas a partir de pontos de dor, boas práticas, percepções distintas entre produtores ou ainda a partir de percepções de possibilidades de melhoria e inovação. Dentre os principais destaques, está a oportunidade de os produtores se unirem para realizarem atividades em conjunto, reduzindo custos e aumentando o domínio sobre suas operações. Oportunidades também envolveram insatisfações dos produtores com o ritmo das inovações tecnológicas, com destaque para questões de mecanização do plantio e desenvolvimento varietal. Uma série de boas práticas adotadas pelos produtores, de natureza tecnológica, gerencial e organizacional, foram apontadas como oportunidades ao servirem de referências para outros produtores. Finalmente, foram identificadas oportunidades para as associações e cooperativas do setor reavaliarem seus serviços no processo de profissionalização dos produtores, além de seu papel como agente facilitador da organização de ações coletivas. A relevância desta pesquisa está relacionada à adaptação e combinação de técnicas e ferramentas identificadas na literatura sobre diagnóstico da experiência do cliente ao contexto do produtor rural, contribuindo, ao mesmo tempo, com um caso prático no contexto B2B. Adicionalmente, os mapas da experiência gerados neste estudo podem ser usados como ferramentas de gestão por empresas do setor para criar uma visão compartilhada entre seus colaboradores, propiciando a geração de ideias para inovar.

Palavras Chave: Diagnóstico da Experiência do Cliente, Perspectiva do Ecossistema do Cliente, Produtor de cana-de-açúcar 


\begin{abstract}
MUNHOS, L. M. Diagnosis of the experience of sugarcane producers in the interior of São Paulo from the perspective of the customer ecosystem. 2019. $195 \mathrm{f}$. Dissertação (Mestrado em Ciências) - Faculdade de Economia, Administração e Contabilidade de Ribeirão Preto, Universidade de São Paulo, Ribeirão Preto, São Paulo, 2019.

The heterogeneity of the world of sugarcane producers, in their different professional and managerial levels, can be used to point out ways to increase the efficiency of the sector. This study aims to complement the initiative of Orplana, the Organization of Sugarcane Producers in the Central-Southern Region of Brazil, to understand the realities of producers and to obtain gains of intelligence for the sector. The objective of the research was to map the experiences of producers of different sizes and verticalization levels, adopting the perspective of their ecosystem, identifying opportunities for the agents of the sector, including the producers themselves, to rethink their actions and their interactions, aiming to improve the competitiveness of the sugarcane chain. The methodology involved qualitative research techniques and visualization diagrams to map the perceptions and interactions of producers throughout the processes they carry out to achieve their objectives. The persona technique was used to represent the experiences of producers of three different profiles. Opportunities have been identified from pain points, good practices, distinct perceptions among producers and from perceptions about possibilities for improvement. Among the highlights is the opportunity for producers to take collective actions, thereby reducing costs and increasing control over their operations. Opportunities also involved producer's dissatisfaction with the pace of technological innovations, in special mechanized planting and varietal development. Several practices adopted by the producers, of technological, managerial and organizational character, were pointed out as opportunities, by serving as references to other producers. Lastly, opportunities were identified for associations and cooperatives to re-evaluate their services, as well as their role as an agent facilitating organization of collective actions. The relevance of this research is related to the adaptation and combination of techniques and tools identified in the literature on the diagnosis of the customer experience to the context of the rural producer, contributing, at the same time, to a practical case in the B2B context. Additionally, the experience maps developed through this research, can be used as tools by companies in the industry to create a shared vision among their employees, enabling the generation of ideas to innovate their offerings. In addition, the experience maps generated in this study can be used as management tools by companies in the industry to create a shared vision among their collaborators, enabling the generation of ideas to innovate.
\end{abstract}

Finally

Key Words: Customer Experience Diagnosis, Customer Ecossystem Perspective, Sugarcane Producer 


\section{LISTA DE ILUSTRAÇÕES}

Figura 1 - Modelo de desenvolvimento de serviços orientado para a co-criação de valor.......27

Figura 2 - Componentes do Desenho de Serviço Multinível..................................................29

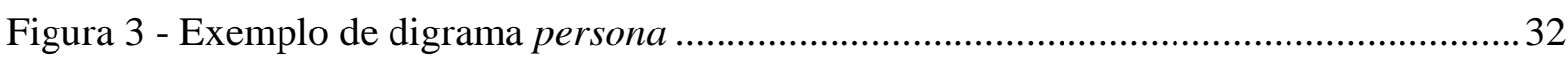

Figura 4 - Exemplo de um blueprint de serviço ................................................................. 35

Figura 5 - Exemplo de mapa da jornada com a representação da persona no topo. ................. 35

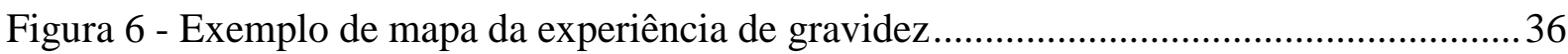

Figura 7 - Construção de persona que representa o segmento criança ....................................37

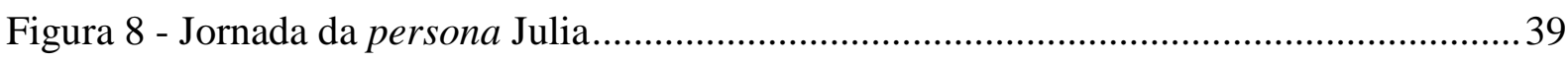

Figura 9 - Critérios de classificação dos produtores de cana-de-açúcar por porte ....................48

Figura 10 - Estratificação dos produtores registrados no sistema ATR da região centro-sul do

Brasil.

Figura 11 - Identificação dos segmentos de produtores de cana-de-açúcar segundo o nível de verticalização

Figura 12 - Análise comparativa da cana adquirida pela indústria conforme sua origem, custo final, graus de eficiência e controles operacionais.

Figura 13: Mapeamento dos processos do produtor de cana-de-açúcar ..................................54

Figura 14 - Ilustração de uma curva de maturação...................................................................57

Figura 15 - Modelo esquemático do sistema de Meisoi na reforma do canavial.

Figura 16 - Serviços mais oferecidos pelas associações e percentual de associações que os oferecem .. 80

Figura 17 - Análise comparativa para construção das personas 142

Figura 18 - Persona que representa o Produtor Integral / Grande 145

Figura 19 - Persona que representa o Produtor Intermediário / Grande 146

Figura 20 - Persona que representa o Produtor Básico / Pequeno 147

Figura 21 - Mapeamento da Experiência de Produtor Integral / Grande. 150

Figura 22 - Mapa da Experiência do Produtor Intermediário / Grande. 151

Figura 23 - Mapa da Experiência do Produtor Pequeno / Básico 152

Figura 24: Análise comparativa das experiências mapeadas. 153 


\section{LISTA DE QUADROS}

Quadro 1 - Principais características dos produtores entrevistados

Quadro 2 - Levantamento das percepções dos produtores relacionadas ao Planejamento

Agrícola

Quadro 3 - Levantamento percepções dos produtores relacionadas à Organização de Recursos

Quadro 4 - Levantamento das percepções dos produtores relacionadas à Produção de Mudas

Quadro 5 - Levantamento das percepções dos produtores relacionadas à Conservação e Preparo do Solo 104

Quadro 6 - Levantamento das percepções dos produtores relacionadas ao Plantio 108

Quadro 7 - Levantamento das percepções dos produtores relacionadas aos Tratos Culturais 111

Quadro 8 - Levantamento das percepções dos produtores relacionadas ao CCT.....

Quadro 9 - Levantamento das percepções dos produtores relacionadas à Comercialização.. 120

Quadro 10 - Levantamento das percepções dos produtores relacionadas ao Planejamento e Gestão de Resultados

Quadro 11 - Levantamento das percepções dos produtores relacionadas às Adequações à Legislação.

Quadro 12 - Levantamento das percepções dos produtores relacionadas à Governança e Sucessão

Quadro 13 - Levantamento das percepções dos produtores relacionadas à Atuação Integrada entre Produtores

Quadro 14 - Quadro comparativo sobre as percepções positivas e negativas levantados nas entrevistas

Quadro 15 - Consolidação das oportunidades identificadas para cada Persona e identificação dos agentes do setor envolvidos 


\section{Sumário}

1 INTRODUÇÃ

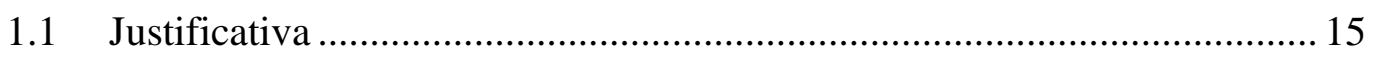

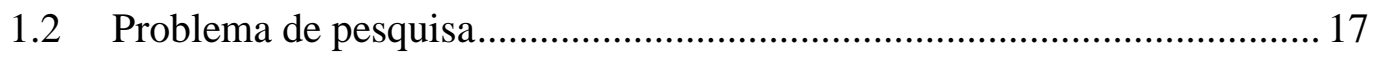

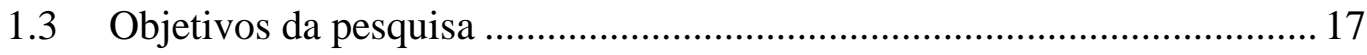

1.4 Organização do Trabalho ……………………………………………...... 18

2 GESTÃO DA EXPERIÊNCIA DO CLIENTE ..............................................19

2.1 Conceito de Experiência do Cliente........................................................... 19

2.1.1 Perspectiva Diádica Firma-Cliente …………………………………..... 19

2.1.2 Perspectiva da Co-criação em Rede.............................................................20

2.1.3 Perspectiva do Ecossistema do Cliente ……………………………….......21

2.2 Gerenciamento da Experiência do Cliente.................................................. 22

2.2.1 Diagnóstico da Experiência do Cliente ………………………………....24

3 ASPECTOS METODOLÓGICOS...........................................................................40

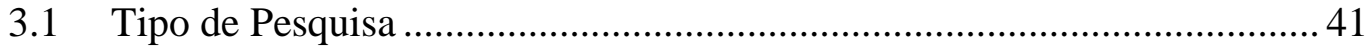

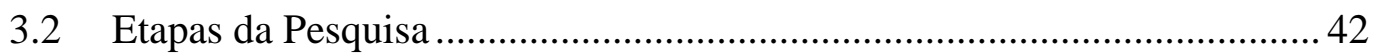

3.2.1 Alinhamento da intenção …………………………………………..... 42

3.2.2 Mapeamento dos processos dos produtores ...............................................4 43

3.2.3 Levantamento das percepções dos produtores .............................................4 43

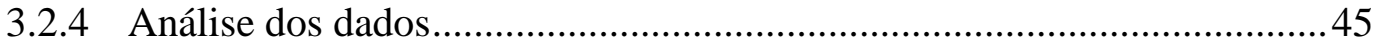

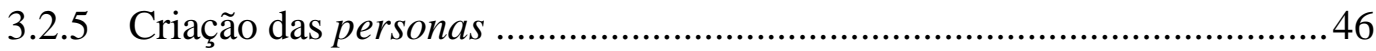

3.2.6 Mapeamento das Experiências e Identificação de Oportunidades ..............46

4 ALINHAMENTO DA INTENÇÃO ............................................................48

5 MAPEAMENTO DOS PROCESSOS DOS PRODUTOR ...................................53

5.1 Processos de Produção ................................................................................ 55

5.1.1 Planejamento Agrícola ..............................................................................5

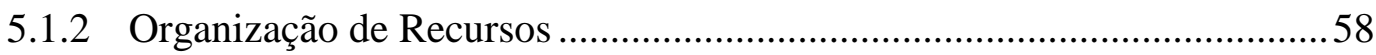

5.1.3 Produção de Mudas ................................................................................5

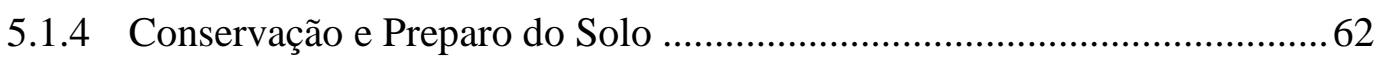




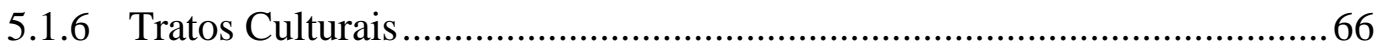

5.1.7 Colheita, Carregamento e Transporte (CCT) .......................................69

5.2 Processo de Comercialização................................................................ 70

5.2.1 Contratos de fornecimento de cana-de-açúcar ..........................................70

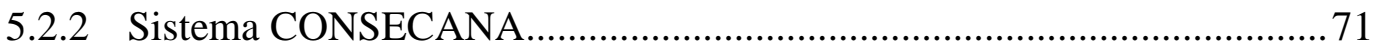

5.3 Processos de Gestão do Negócio ........................................................... 73

5.3.1 Planejamento e Gestão de Resultados.................................................... 73

5.3.2 Adequação à Legislação........................................................................ 74

5.3.3 Governança e Sucessão ......................................................................... 77

5.3.4 Atuação integrada entre os produtores .................................................. 78

\section{LEVANTAMENTO DAS PERCEPÇÕES DOS PRODUTORES DE CANA83}

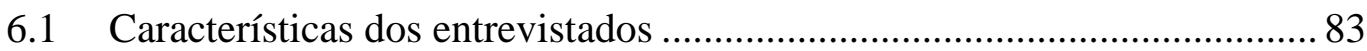

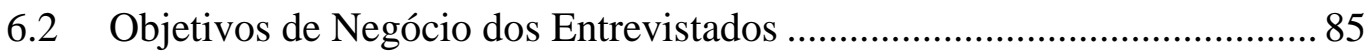

6.3 Análise das experiências ao longo dos processos ...................................... 86

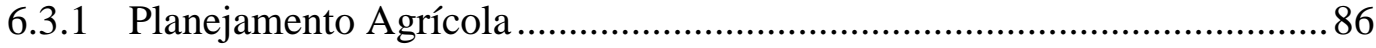

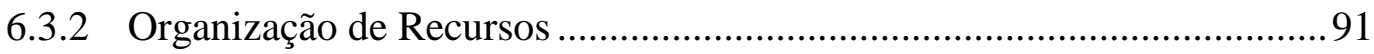

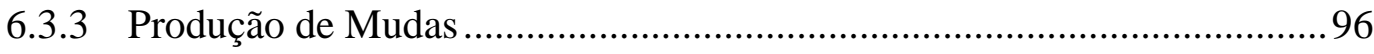

6.3.4 Conservação e Preparo do Solo ............................................................ 100

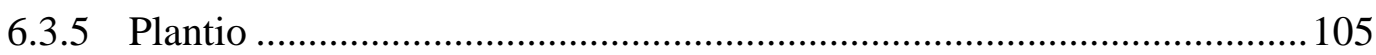

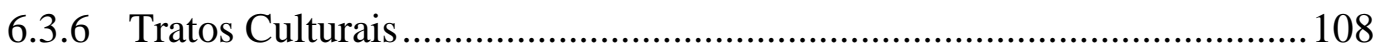

6.3.7 Colheita, Carregamento e Transporte ................................................ 111

6.3.8 Comercialização............................................................................. 114

6.3.9 Planejamento e Gestão de Resultados................................................. 121

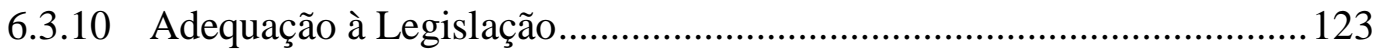

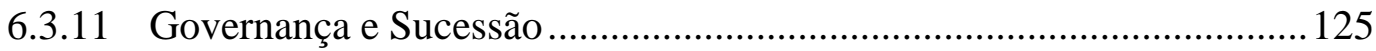

6.3.12 Atuação integrada entre produtores ..............................................127

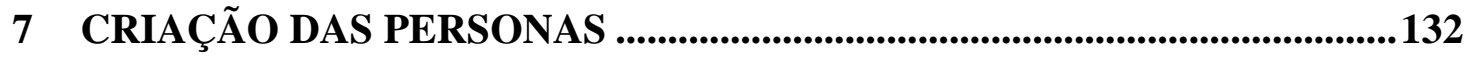


7.1 Construção das personas

141

8 MAPEAMENTO DAS EXPERIÊNCIAS E IDENTIFICAÇÃO DE OPORTUNIDADES

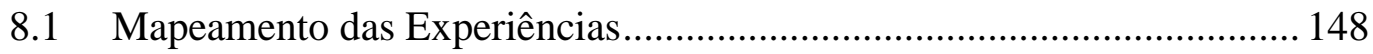

8.2 Análise comparativa das Experiências................................................. 153

8.3 Análise das oportunidades identificadas ............................................... 156

8.3.1 Oportunidades relacionadas ao Planejamento Agrícola........................... 164

8.3.2 Oportunidades relacionadas à Organização de Recursos ........................ 165

8.3.3 Oportunidades relacionadas à Produção de Mudas................................. 167

8.3.4 Oportunidades relacionadas à Conservação e Preparo do Solo ............... 169

8.3.5 Oportunidades relacionadas ao Plantio .................................................. 170

8.3.6 Oportunidades relacionadas aos Tratos Culturais ............................... 170

8.3.7 Oportunidades relacionadas ao CCT ................................................... 171

8.3.8 Oportunidades relacionadas à Comercialização .................................... 172

8.3.9 Oportunidades relacionadas ao Planejamento e Gestão de Resultados .. 174

8.3.10 Oportunidades relacionadas à Adequação à Legislação ....................... 175

8.3.11 Oportunidades relacionadas à Governança e Sucessão........................ 175

8.3.12 Oportunidades relacionadas à Atuação Integrada entre Produtores...... 176

9 CONCLUSÕES, IMPLICAÇÕES GERENCIAIS E LIMITAÇÕES DA

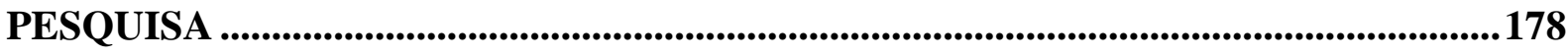

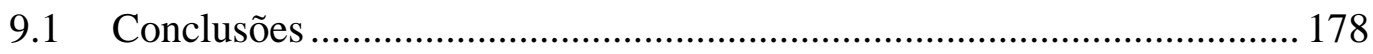

9.1.1 Alcance dos objetivos da pesquisa .................................................. 180

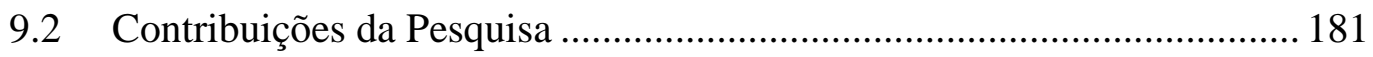

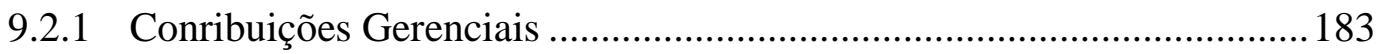

9.3 Limitações e recomendações para pesquisas futuras .............................. 183

10 REFERÊNCIAS BIBLIOGRÁFICAS ..................................................185

APÊNDICE A - Termo de confidencialidade.........................................................194

APÊNDICE B - Roteiro das Entrevistas............................................................... 195 


\section{INTRODUÇÃO}

A ênfase que as organizações têm colocado no cliente mudou drasticamente ao longo da história da administração moderna. Na era da produção em massa, em um cenário em que a oferta era menor do que a demanda, o cliente era colocado de lado e aceitava a padronização dos produtos imposta pelas organizações. Com o aumento da competitividade, principalmente após a Segunda Guerra Mundial, gradativamente, o cliente começou a ocupar uma posição mais central na estratégia das organizações. As organizações começaram a se preocupar em entregar cada vez mais valor para o cliente, primeiro através do foco na qualidade dos produtos, depois na gestão de serviços e, já na década de 1990s, através da gestão do relacionamento com o cliente (LEMON; VERHOEF, 2016) .

Foi a partir dos anos 2000, com o advento da era digital, que a gestão da experiência do cliente começou a ser vista como um requisito estratégico de competição. Os clientes foram se tornando cada vez mais empoderados e ativos. Passaram a ter à sua disposição ferramentas e informações para encontrar, avaliar alternativas e combinar produtos e serviços para satisfazer suas necessidades. O cliente passou a participar ativamente da criação de valor, interagindo com diversas empresas, através de um número enorme de pontos de contato e múltiplos canais (LEMON; VERHOEF, 2016; PATRICIO et al., 2011; PRAHALAD; RAMASWAMY, 2004a).

Dentro deste mesmo cenário, a disseminação rápida de informações, conhecimentos e melhores práticas tem encurtado o tempo entre a inovação e a cópia, o que vem tornando mais difícil a criação de diferenciação com base em atributos de produtos ou serviços. É o chamado "fenômeno da comoditização", em que o cliente acaba escolhendo com base em mínimos detalhes e preço (CHESBROUGH, 2011; PINE II; GILMORE, 2016).

Todos estes fatores têm forçado as organizações a buscarem um novo foco. Mais do que características e benefícios do produto ou serviço, o conceito de valor foi expandido para a experiência do cliente (CHESBROUGH, 2011; FROW; PAYNE, 2007; GRÖNROOS; VOIMA, 2013; HELKKULA; KELLEHER; PIHLSTRÖM, 2012; VARGO; LUSCH, 2008).

O conceito de experiência do cliente evoluiu desde que foi abordado pela primeira vez por Holbrook e Hirschman (1982). A ênfase dada pelos autores foi nos aspectos emocionais do consumo. Desde então, diversos autores têm abordado a experiência do cliente como o resultado cumulativo de suas respostas em cada ponto de contato com a organização, envolvendo aspectos emocionais, cognitivos, sensoriais, sociais e espirituais (GENTILE; SPILLER; NOCI, 2007; MEYER; SCHWAGER, 2007; PUCCINELLI et al., 2009; SCHMITT, 2004) . Jornada do cliente é o termo que foi amplamente disseminado para definir este processo de interação e 
relacionamento do cliente com a organização e que ocorre antes, durante e após a compra dos produtos ou serviços. Para gerenciar a experiência do cliente, muitas empresas adotam ferramentas para mapear e desenhar a jornada do cliente, planejando estímulos que irão gerar reações cognitivas ou emocionais em cada ponto de contato (MEYER; SCHWAGER, 2007; VERHOEF et al., 2009).

A visão de que o cliente assume um papel mais ativo na criação de suas experiências, ao combinar soluções de diversos provedores, interagir com outros clientes e influenciar as ofertas das organizações (PRAHALAD; RAMASWAMY, 2004a), levou à configuração de uma nova perspectiva sobre a formação da experiência do cliente. Esta perspectiva começou a ser delineada com a disseminação da Lógica-Dominante de Serviços ( $S$-D Logic) (VARGO; LUSCH, 2004, 2008). O Serviço passou a ser entendido como uma perspectiva de gestão de negócio e não mais como um tipo especial de indústria, como a de saúde ou de educação, por exemplo. O valor do serviço passou a ser caracterizado por sua natureza experiencial e passou ser visto como um processo que envolve o cliente através de interações. Além disso, a visão diádica firma-cliente, em que o cliente simplesmente reage aos estímulos planejados pela organização, foi ampliada e passou a enfatizar a experiência como um fenômeno coletivo, que envolve diversos atores, que interagem através de uma rede de serviços. O cliente co-cria valor em rede ao integrar recursos disponibilizados pela empresa com recursos de outros fornecedores, parceiros, clientes e inclusive recursos próprios (GRÖNROOS; VOIMA, 2013; VARGO; LUSCH, 2008).

Uma outra perspectiva, com foco ainda mais ampliado sobre a experiência, que surgiu como um desdobramento da Lógica Dominante de Serviços, foi a Lógica Dominante do Cliente (HEINONEN et al., 2010; HEINONEN; STRANDVIK, 2015; HEINONEN; STRANDVIK; VOIMA, 2013). Os autores propõem a mudança da perspectiva do provedor para o cliente. Segundo eles, a rede de serviços estaria colocando o provedor no centro e não o cliente. A orientação é criar um entendimento holístico do contex to das vidas ou dos negócios dos clientes, englobando atividades e práticas relacionadas ou não ao core dos serviços da empresa. Os autores adotam o termo Ecossistema do Cliente para descrever os processos e o sistema de atores com quem o cliente está envolvido.

A partir desta ampliação do escopo da gestão da experiência, as organizações buscam entender a lógica do cliente, ou seja, conhecer em que processos ou atividades os clientes estão envolvidos nos seus próprios contextos e que tipo de solução podem oferecer para apoiar tais processos. 
Técnicas qualitativas de pesquisa e métodos de visualização são recomendados na literatura para compreender a complexidade e a intangibilidade das experiências. As abordagens propostas para mapear a experiência no nível do ecossistema do cliente envolvem diagramas de visualização, que podem ter uma estrutura cronológica, enfatizando os processos, ou espacial, enfatizando as interações (KALBACH, 2017; PATRICIO et al., 2011; TRISCHLER; ZEHRER, 2012).

\subsection{Justificativa}

O complexo agroindustrial sucroenergético tem uma grande importância econômica e social para o Brasil, contribuindo com um PIB R\$ US\$ 43 bilhões, o que equivale à aproximadamente 2\% do PIB (NEVES et al., 2014) e gerando 2,4 milhões de empregos formais e informais (UNIÃO DA INDÚSTRIA DE CANA-DE-AÇÚCAR (UNICA), 2018) . Do ponto de vista ambiental, a produção de etanol e outros produtos como fonte de energia renovável, coloca o Brasil em uma posição de referência mundial por ofertar alternativa econômica e ecologicamente viável à substituição de combustíveis fósseis (BRASIL, 2019).

Apesar da projeção de um horizonte favorável, delineado pelo aumento do consumo de biocombustível, alimentos e energias renováveis, as unidades de produção, tanto agrícolas, quanto industriais, no Brasil vêm enfrentando dificuldades econômicas nos últimos anos. Algumas até entraram em processo de dissolvência. Fatores relacionados ao preço do produto e à elevação no custo de produção com mão de obra, adequações ambientais e legais, bem como elevada carga tributária e custos logísticos têm importância neste cenário (NEVES et al., 2018).

No universo dos produtores de cana-de-açúcar, que desempenham um importante papel na cadeia produtiva como fornecedores de matéria-prima, os impactos causados por estes fatores vêm desencadeando uma demanda urgente por mudanças.

A Orplana, Organização de Plantadores de Cana da Região Centro-Sul do Brasil, formada por 32 associações, representando aproximadamente 10.000 produtores de cana-deaçúcar, assumiu este desafio. A sua missão é "Garantir um futuro seguro e rentável para os produtores de cana-de-açúcar, buscando excelência na produção agrícola e coordenação da cadeia sucroenergética” (ORPLANA, 2019).

Para alcançar este propósito, o plano de gestão da Orplana está orientado para desenvolver uma comunidade profissionalizada de produtores de cana através de sinergias e ações coletivas, tanto entre produtores, como entre os agentes pertinentes à cadeia da cana ${ }^{1}$.

\footnotetext{
${ }^{1}$ Informações fornecidas pela Gestão Executiva da Orplana
} 
Compreender a heterogeneidade do mundo dos produtores é uma estratégia importante para obter um ganho de inteligência, permitindo com que associações, empresas fornecedoras e órgãos públicos possam elaborar ofertas direcionadas para cada segmento. Além das informações conhecidas, relacionadas ao porte e à capacidade produtiva das unidades da região centro-sul, o desafio é conhecer as especificidades quanto aos perfis dos produtores e quanto à realização das operações nas diversas fases da cultura, desde o plantio até a colheita.

A organização desenvolveu um projeto de pesquisa com o objetivo de estratificar e caracterizar produtores, bem como, analisar a eficiência econômica e produtiva dos distintos sistemas de produção ${ }^{2}$.

Uma das frentes do estudo, realizada em parceria com o Instituto de Pesquisa Educação Continuada em Economia e Gestão de Empresas (PECEGE), envolveu uma análise comparativa, a partir de uma base apurada e padronizada de custos, sobre a eficiência operacional dos distintos níveis de verticalização adotados pelos produtores independentes. Os resultados apontam para a conclusão de que, quanto maior o controle e domínio dos custos e operações (plantio, tratos culturais, corte-transbordo-transporte), menores serão os custos e menos oneroso será o custo final da cana entregue na esteira da usina ${ }^{3}$.

Complementarmente, está sendo realizado um levantamento quantitativo para identificar a representatividade destes sistemas produtivos na região de abrangência da Orplana, além de identificar outras características relacionadas ao perfil das propriedades, níveis tecnológicos, relacionamento com as usinas, entre outros.

A presente pesquisa visa contribuir com o projeto da Orplana através das lentes da gestão da experiência do cliente. Ao adotar técnicas qualitativas de pesquisa para o mapeamento das experiências no nível do ecossistema do produtor de cana-de-açúcar, esta investigação busca explorar o contexto em que produtores de diferentes portes e níveis de verticalização estão inseridos, identificando os seus objetivos, seus processos, seus desafios, suas escolhas gerenciais, e suas percepções sobre os serviços e tecnologias disponíveis.

Como metodologia escolhida está orientada para a perspectiva do ecossistema do cliente, a contribuição deste estudo vai ao encontro do propósito da Orplana de identificar oportunidades envolvendo os agentes do setor. Desta forma, as experiências dos produtores poderão ser exploradas a partir dos processos que eles realizam para alcançar seus objetivos,

\footnotetext{
${ }^{2}$ NEVES et al., Segmentação e Análise da Eficiência Técnica e Econômica de Produtores de Cana-de-Açúcar na Região Centro/Sul. Ribeirão Preto, 2018. (Projeto de pesquisa / Ainda não publicado)

${ }^{3}$ Informações fornecidas pela Gestão Executiva da Orplana (Ainda não publicadas).
} 
envolvendo múltiplos atores com quem se relacionam. A partir desta perspectiva, os aspectos relevantes das experiências, positivos ou negativos, possibilitarão a identificação de oportunidades para que estes agentes, incluindo os próprios produtores, elevem a competitividade do setor

Como este estudo é de caráter exploratório, utilizando-se de uma pequena amostra de produtores do interior de São Paulo, espera-se que os resultados obtidos sirvam de base para uma ampliação da pesquisa, sendo possível compreender, de forma mais abrangente, as distintas experiências existentes no restante da região centro-sul do Brasil.

\subsection{Problema de pesquisa}

Diante da justificativa apresentada, uma questão central é construída para direcionar esta pesquisa:

Quais aspectos das experiências dos produtores de cana-de-açúcar de diferentes portes e graus de verticalização, no nível do seu ecossistema, podem gerar oportunidades para os agentes do setor repensarem suas ações e suas interações para melhorar a competitividade da cadeia sucroenergética?

\subsection{Objetivos da pesquisa}

Portanto, o objetivo geral desta pesquisa é mapear as experiências no nível do ecossistema de produtores de cana-de-açúcar, de diferentes portes e níveis de verticalização, identificando oportunidades para os agentes do setor, incluindo os próprios produtores, repensarem suas ações e suas interações, visando melhorar a competitividade da cadeia sucroenergética.

O objetivo geral foi desdobrado nos seguintes objetivos específicos:

- Identificar técnicas e ferramentas na literatura que possam ser adaptadas ou combinadas para fazer o mapeamento das experiências pertinentes aos processos dos produtores de cana-de-açúcar.

- Mapear os processos de produção, comercialização e gestão dos produtores de canade-açúcar.

- Ao longo dos processos, através de pesquisas qualitativas, identificar os desafios de produtores de distintos graus de verticalização e portes e levantar as suas percepções sobre os serviços e tecnologias disponíveis. 
- Identificar padrões comuns entre os entrevistados e criar personas que possam representar as experiências de produtores de diferentes níveis de verticalização e porte.

- Mapear a experiência na perspectiva do ecossistema do cliente para cada persona, identificando seus objetivos, o conjunto de decisões gerenciais tomadas, suas percepções ao longo de toda a experiência e os atores envolvidos.

- Analisando comparativamente os aspectos relevantes das experiências de cada persona, identificar oportunidades para desenvolver um ecossistema mais integrado, elevando a eficiência do produtor e a competitividade do setor

\subsection{Organização do Trabalho}

Esta pesquisa está dividida em 9 capítulos.

O capítulo 1 faz uma introdução sobre o assunto central da dissertação, apresenta os principais conceitos sobre experiência do cliente, assim como apresenta uma justificativa sobre o foco do estudo. Neste mesmo capítulo é descrito o problema de pesquisa, assim como o objetivo geral e os objetivos específicos a serem atingidos.

No capítulo 2, a fundamentação teórica sobre experiência do cliente é apresentada, assim como as abordagens metodológicas de gestão da experiência do cliente, colocando-se ênfase nas técnicas de diagnóstico e mapeamento de experiências que é o foco do estudo.

No capítulo 3 são descritos os procedimentos metodológicos adotados nesta pesquisa, que foram embasados nas propostas metodológicas apresentadas no capítulo anterior.

Os capítulos de 4 a 8 relacionam-se à realização das etapas da pesquisa. $\mathrm{O}$ capítulo 4 trata-se do alinhamento da intenção do projeto junto à organização envolvida. No capítulo 5 é apresentado o mapeamento dos processos do produtor de cana-de-açúcar, construídos com base na literatura. O capítulo 6 trata do levantamento das percepções dos produtores e identificação dos aspectos positivos e negativos ao longo de suas experiências. No capítulo 7 são apresentadas as personas construídas para representar os distintos perfis de produtores identificados. Finalmente, no capítulo 8 são apresentados os mapeamentos das experiências de cada persona através de diagramas de visualização e a identificação de oportunidades envolvendo os agentes do setor.

No capítulo 9 são apresentadas as principais conclusões do estudo, bem como o cumprimento dos objetivos propostos, suas implicações gerenciais e acadêmicas e as limitações e oportunidades de pesquisas futuras. 


\section{GESTÃO DA EXPERIÊNCIA DO CLIENTE}

Por ser uma nova área de conhecimento, é importante diferenciar o conceito experiência do cliente dos demais conceitos dentro da área de marketing e compreender em que pontos eles se relacionam. Lemon e Verhoef (2016) contribuem com este esclarecimento ao traçar as origens da experiência do cliente a partir de diversas vertentes do marketing:

O marketing de serviços, da década de 1980, é considerado um precursor da experiência do cliente ao valorizar algumas características especiais dos serviços, como intangibilidade e interações pessoais. O Blueprint de Serviços, que é uma ferramenta desenvolvida dentro do marketing de serviços, com o reconhecimento dos chamados "momentos da verdade", é outra influência, pois também é utilizada para mapear experiências, dentro de um escopo das interfaces do cliente com o serviço. (LEMON; VERHOEF, 2016).

O marketing de relacionamento, na década de 1990, também influenciou a formação do conceito de experiência do cliente ao ampliar o escopo das respostas do consumidor incluindo fatores emocionais, como confiança, comprometimento e qualidade do relacionamento. A abordagem de centralidade ou foco no cliente, nas décadas de 2000 e 2010, trouxe a perspectiva do cliente para dentro de toda a organização e a noção da jornada de compra sob a perspectiva do cliente. Por fim, o movimento do engajamento do cliente, na década atual, contribuiu com o desenvolvimento da experiência do cliente ao reconhecer o valor nas interações fora da compra e ao reconhecer que o engajamento ocorre a partir de experiências interativas e co-criativas. (LEMON; VERHOEF, 2016).

\subsection{Conceito de Experiência do Cliente}

Três perspectivas diferentes adotadas na literatura para definir a formação da experiência do cliente serão exploradas neste capítulo. A primeira está centrada na relação diádica firma-cliente, onde estímulos são planejados ao longo de todos os pontos de contato do cliente com a organização, gerando reações nos clientes. A segunda perspectiva, que é mais moderna, está orientada para a co-criação de experiências de forma coletiva. O cliente integra recursos de diversos atores para criar valor experiencial.

\subsubsection{Perspectiva Diádica Firma-Cliente}

A construção da experiência ocorre através de uma coleção de pontos de contato ao longo de todas as fases do processo de compra do cliente, também chamada de jornada do 
cliente (IVENS; SHAW, 2002; LEMON; VERHOEF, 2016; PUCCINELLI et al., 2009). A ideia central é expandir a noção baseada em transação do relacionamento com o cliente para o conceito contínuo da experiência do cliente (GENTILE; SPILLER; NOCI, 2007). A experiência do cliente envolve processos que ocorrem antes, durante e após a compra dos produtos ou serviços. As atividades que ocorrem antes da compra envolvem interações com a marca, recomendações, reconhecimento da necessidade, pesquisa e consideração. As interações do cliente durante o evento específico de compra ocorrem através dos canais de vendas e estão relacionadas às compras, interações durante a prestação de serviços, pagamentos etc. As atividades que ocorrem após a compra estão relacionadas ao uso ou consumo, solicitação de serviços, avaliação e engajamento. A experiência do cliente passa a ser um resultado cumulativo da percepção do cliente ao longo de todos os pontos de contato ao longo da sua jornada (MEYER; SCHWAGER, 2007).

A experiência do cliente é uma resposta interna e subjetiva do cliente a qualquer contato, com a empresa (MEYER; SCHWAGER, 2007). A experiência é percebida puramente do ponto de vista do consumidor e é inerentemente pessoal, só existe na mente do cliente (PINE; GILMORE, 1999). As respostas dos clientes podem envolver componentes cognitivos, emocionais, comportamentais, sensoriais, sociais ou espirituais (GENTILE; SPILLER; NOCI, 2007; SCHMITT, 2004; VERHOEF et al., 2009). O valor da experiência pode ser avaliado intuitivamente pelo cliente, tanto pelo desempenho de seus atributos funcionais, quanto através de atributos emocionais (CARBONE, 2004; IVENS; SHAW, 2002).

Portanto, segundo esta perspectiva, as organizações planejam estímulos físicos e emocionais em cada ponto de contato, que de forma integrada irão gerar uma resposta pessoal do cliente sobre sua experiência.

\subsubsection{Perspectiva da Co-criação em Rede}

A perspectiva da co-criação de experiências em rede começou a ser delineada com a proposição da Lógica Dominante de Serviços, SD-Logic (LUSCH; VARGO, 2006; VARGO; LUSCH, 2004, 2008). A palavra Serviço passou a ser entendida como uma perspectiva de gestão de negócio e não mais como uma alternativa aos produtos. O termo Serviço (no singular) passou a se diferenciar do termo Serviços (no plural). Enquanto Serviços (no plural) são vistos como tipos especiais de produtos ou produtos intangíveis (como saúde educação), Serviço (no singular) passou a ser entendido como a aplicação de competências em benefício de outros, tornando-se base para qualquer tipo de troca. $\mathrm{O}$ foco mudou de características e atributos dos 
produtos e serviços para a criação de valor, cuja natureza é experiencial e contextual (GRÖNROOS, 2011; VARGO; LUSCH, 2008).

O conceito de interação é chave no processo de co-criação de valor (CARÙ; COVA, 2015; MCCOLL-KENNEDY; CHEUNG; FERRIER, 2015; VARGO; LUSCH, 2008). Durante as interações do cliente com o provedor de serviços, os processos de produção e uso estão simultaneamente ocorrendo e, portanto, ambas as partes estão influenciando o processo conjunto, integrando recursos e colaborando para a criação de valor. Desta forma, durante as interações, tanto a organização quanto o cliente são co-criadores de valor (GRÖNROOS, 2011). Um ponto importante e ser reforçado é que o termo co-criação é diferente de co-produção ou co-design. Enquanto a co-criação de valor ocorre durante o uso, a co-produção ou co-design envolve a participação do cliente na criação ou desenho dos serviços na sua concepção, previamente ao uso (LUSCH; VARGO 2006).

No modelo de relacionamento dos mercados modernos, o processo de co-criação de experiências passa a ser entendido como um fenômeno coletivo, que envolve diversos atores que interagem entre si através de uma rede de serviços. $\mathrm{O}$ cliente co-cria valor em rede ao integrar recursos disponibilizados pela empresa com recursos de outros fornecedores e inclusive recursos próprios, necessários para atingir os seus objetivos. (GRÖNROOS; VOIMA, 2013; VARGO; LUSCH, 2008). Redes de experiências são não lineares, compostas por interações não sequenciais entre empresas, instituições e comunidades de clientes que se relacionam entre si e com o cliente, criando um ambiente experiencial (PRAHALAD; RAMASWAMY, 2004b).

\subsubsection{Perspectiva do Ecossistema do Cliente}

Uma nova perspectiva, que surgiu de um desdobramento da $S D$-Logic, amplia ainda mais o escopo da gestão da experiência do cliente. É a Lógica Dominante do Cliente, CD-Logic, que foi proposta por Heinonen et al. (2010) e adota uma mudança da perspectiva do provedor para o cliente. Os autores argumentam que o modelo mental da SD-Logic adota o uma análise conceitual de dominância do provedor de serviços em contraste com a dominância do cliente. Ao invés de focar no que as empresas estão fazendo para criar serviços para os clientes, o foco deveria ser no que os clientes estão fazendo com os serviços para atingir seus objetivos. O que precisa ser compreendido é como, através de um processo de construção de sentido, os clientes constroem sua experiência a partir da participação dos provedores de serviços em suas atividades e tarefas.

Ao invés de envolver os clientes na co-criação, os serviços deveriam se concentrar em se envolver nos processos do cliente. $\mathrm{O}$ foco parte de um entendimento holístico sobre o contexto 
das vidas ou negócios dos clientes, englobando atividades e práticas relacionadas ou não ao core dos serviços da empresa. Segundo esta visão, quem pode orquestrar a criação de valor é o cliente e não a empresa (HEINONEN et al., 2010; HEINONEN; STRANDVIK, 2015).

Os autores adotam o termo Ecossistema do Cliente para descrever o sistema de atores com quem o cliente está envolvido. A CD-Logic enfatiza o cliente como a principal parte interessada, não o serviço ou o sistema de serviços. O foco não está nas interações clientefornecedor (nem em um nível diádico nem de rede de serviço), mas em como os clientes usam e aplicam diferentes elementos de serviço em suas próprias vidas ou negócios (HEINONEN; STRANDVIK, 2015; JAAKKOLA; HELKKULA; AARIKKA-STENROOS, 2015).

\subsection{Gerenciamento da Experiência do Cliente}

Diante deste contexto, o desafio das organizações é desenvolver a capacidade de gerenciar a experiência do cliente, ou seja, planejar, implementar e sustentar suas ofertas, dentro de um sistema complexo, integrando-as com outros atores, serviços e tecnologias, para viabilizar experiências significativas ao cliente.

Segundo Lemon e Verhoef (2016), a literatura sobre gerenciamento da experiência do cliente ainda é bastante escassa. A maioria das abordagens tem sido apresentada por autores práticos.

Desde o final da década de 1990, as primeiras propostas metodológicas para gerenciar a experiência do cliente através de um processo de gestão estruturado e holístico, começaram a ser propostas (CARBONE, 2004; IVENS; SHAW, 2002; PINE; GILMORE, 1999; SCHMITT, 2004). Já em 2011, Johnston e Kong, a partir do estudo de múltiplos casos com empresas de diferentes setores, propuseram um roteiro para gerenciar a experiência do cliente. Contribuições importantes sobre métodos de gestão da experiência também foram identificadas na literatura de Desenvolvimento de Novos Serviços (YU; SANGIORGI, 2018; ZOMERDIJK; VOSS, 2011).

O primeiro passo para implementar um sistema de gestão da experiência do cliente, segundo alguns destes autores, é o alinhamento da intenção de gerenciar a experiência do cliente à estratégia organizacional (CARBONE, 2004; IVENS; SHAW, 2002; JOHNSTON; KONG, 2011). Um dos fatores críticos de sucesso apontados é a delegação do projeto a uma liderança de alto nível, com o envolvimento de uma equipe multidisciplinar, capaz de conduzir as mudanças através dos diversos departamentos da organização (CARBONE, 2004; IVENS; 
SHAW, 2002; JOHNSTON; KONG, 2011; RAWSON et al., 2013; ZOMERDIJK; VOSS, 2011).

Uma vez estabelecido o projeto, Ivens e Shaw (2002) propõem a definição da Declaração da Experiência do Cliente, baseada nos valores e promessas da marca, com o intuito de criar alinhamento e direcionamento das ações do projeto. Na mesma direção, Carbone (2004) sugere que seja definido o Motif, ou seja, uma caracterização geral da experiência, que reflete os valores do core e a estratégia da marca. Da mesma forma, o método proposto por Johnston e Kong (2001) envolve a articulação da Definição da Experiência, incluindo as emoções que a empresa deseja que o cliente sinta.

A realização do diagnóstico da experiência do cliente é uma atividade crítica para identificar desconexões e oportunidades para uma nova proposta experiencial. Pesquisas qualitativas, fazendo uso de técnicas etnográficas e empáticas, são indicadas para coletar insights profundos sobre como os clientes se sentem durante suas experiências (CARBONE, 2004; IVENS; SHAW, 2002; JOHNSTON; KONG, 2011; YU; SANGIORGI, 2018; ZOMERDIJK; VOSS, 2011). Ivens e Shaw (2002) adotam a técnica de mapeamento dos momentos de contato ao longo da experiência atual do cliente. Carbone (2004) propõe o mapeamento das pistas que estão sendo enviadas para o cliente, funcionais, mecânicas e humanas. O mapeamento da jornada do cliente, incluindo os pontos de contato com a organização, é uma ferramenta de visualização amplamente utilizada para compreender os processos do cliente (JOHNSTON; KONG, 2011; YU; SANGIORGI, 2018; ZOMERDIJK; VOSS, 2011). Yu e Sangiorgi (2017) propõem a visualização da experiência holística do cliente através da jornada, com múltiplos canais e pontos de contato dentro de um sistema de serviço.

Uma vez compreendidas as experiências atuais do cliente, o próximo passo, para Carbone (2004), é o redesenho das experiências, fazendo uso de ferramentas de visualização e narrativas para orquestrar as pistas a serem enviadas aos clientes. Ivens e Shaw (2002) trabalham com o desenho dos possíveis caminhos que o cliente pode escolher ao longo de sua experiência e a redefinição dos elementos físicos e emocionais nos pontos de contato.

A pilotagem das ideias é uma atividade bastante comum nas abordagens de redesenho das experiências. Ao olhar os processos pelo ponto de vista do cliente, os colaboradores e fornecedores geram ideias que podem ser testadas com a obtenção de feedbacks dos clientes (JOHNSTON; KONG, 2011). Rawson et al., (2013) sugerem um levantamento de causas e proposição de soluções para os problemas identificados nos mapas das jornadas, seguido de pilotagem das ideias com times de linha de frente. Yu e Sangiori (2017) também incluem em 
seu modelo a atividade de prototipagem para explorar as experiências e aprender como os usuários;

Os passos seguintes envolvem o desenvolvimento das mudanças propostas através da alteração dos processos e sistemas, desenvolvimento da comunicação interna e externa, treinamento dos envolvidos e lançamento (IVENS; SHAW, 2002; JOHNSTON; KONG, 2011; YU; SANGIORGI, 2018; ZOMERDIJK; VOSS, 2011).

Finalmente, para garantir a sustentabilidade e evolução das experiências, é importante a existência de um sistema de gestão interconectado e alinhado à estratégia organizacional. Shaw e Ivens (2002) apontam para a necessidade de um desdobramento de métricas a partir da Declaração da Experiência, com ênfase nas emoções dos clientes. Carbone (2004), da mesma forma, sugere a definição de métricas a partir do Motif. Zomerdijk e Voss (2011) também apontam para a necessidade de adoção de métricas para avaliar as emoções dos clientes. Para Johnston e Kong (2011) é importante também ajustar estas métricas aos programas de incentivos. Yu e Sangiori (2017) propõem a medição do impacto dos novos serviços nas experiências dos clientes, além do uso de ferramentas e diretrizes de gerenciamento de serviços.

Poucas abordagens de gestão da experiência do cliente adotam a perspectiva de cocriação de valor em rede ou do ecossistema do cliente. A maioria das propostas são baseadas ainda na perspectiva voltada para o estímulo organização-cliente (LIPKIN, 2016). Segundo (JAAKKOLA; HELKKULA; AARIKKA-STENROOS, 2015), as pesquisas em desenho, inovação e gestão tem focado mais em planejar e orquestrar estímulos em cada ponto de contato do cliente com a organização.

Dentre as abordagens descritas acima, a única a adotar ferramentas que propiciam a visão da experiência em rede é a de Yu e Sangiorgi (2017). Eles incluem em seu modelo atividades como acesso às experiências contextuais e holísticas dos clientes, co-design do serviço com os clientes e alinhamento e mobilização dos atores que participam da rede de serviços. Algumas características deste modelo serão mais detalhas no próximo capítulo.

\subsubsection{Diagnóstico da Experiência do Cliente}

A realização de um diagnóstico sobre as experiências atuais dos clientes, fazendo uso de pesquisas qualitativas e diagramas de visualização, é uma das atividades essenciais às abordagens propostas na literatura para gerenciar a experiência do cliente. Este fato pode ser percebido a partir dos métodos apresentados acima. Todos os autores incluíram estas atividades em seus métodos de gestão. 
O uso de mapas visuais da experiência do cliente ajuda a mudar o modelo mental das pessoas, ao fazer com que vejam seus serviços pelo ponto de vista do cliente, ou seja, "de fora para dentro" e não de "dentro para fora". Atualmente as equipes estão muito mais focadas nos processos internos e acabam ignorando os processos do cliente (IVENS; SHAW, 2002; JOHNSTON; KONG, 2011; KALBACH, 2017).

Este olhar de "dentro para fora" acaba gerando uma atuação a partir de "silos", ou seja, as pessoas têm dificuldade de ver as interdependências na organização. As equipes ficam desalinhadas e acabam focando mais na tecnologia do que na experiência (IVENS; SHAW, 2002; KALBACH, 2017).

As visualizações das experiências podem interromper o pensamento em silo, servindo como um modelo no qual as equipes podem se apoiar. O mapeamento da experiência é importante pois permite a criação de uma visão compartilhada, permitindo o entendimento de onde as experiências estão sendo atualmente bem suportadas ou não (KALBACH, 2017; RAWSON et al., 2013).

A partir desta compreensão, é possível identificar oportunidades de inovação. O diagnóstico cria um entendimento amplo que ajuda a focar o orçamento de desenho e recursos tecnológicos (RISDON, 2011). Segundo Carbone (2004), o principal resultado desta etapa será criar um entendimento estratégico sobre como alavancar a experiência do cliente, o que levará a um plano tático de como chegar lá. A ideia é direcionar recursos e esforços orientados para os diferentes públicos e atividades e, desta forma, criar foco e definir prioridades que irão direcionar todos os esforços.

$\mathrm{Na}$ literatura acadêmica, poucas abordagens de diagnóstico da experiência adotam a perspectiva da rede de serviços ou do ecossistema do cliente, ou seja, poucas propõem técnicas para compreender e mapear o contexto mais amplo em que o cliente está inserido e identificar os atores com quem ele se relaciona fora dos limites de interação com a organização.

A seguir serão descritas quatro abordagens para diagnosticar das experiências que contribuíram com as escolhas metodológicas deste estudo.

Uma delas é o trabalho de Yu e Sangiorgi (2017), citada no capítulo anterior, e que contribuiu por incluir em seu modelo, atividades como o acesso às experiências contextuais e holísticas dos clientes.

A segunda abordagem é o método multinível de Patricio et al. (2011), em que a as experiências são mapeadas em três níveis: (1) o nível da constelação de valor, equivalente ao ecossistema, (2) o nível da jornada e (3) o nível do ponto de contato. 
No meio prático, foi mais fácil identificar livros, websites e artigos especializados que atuam na perspectiva do ecossistema. Kalbach (2017), a partir de sua experiência como designer, apresenta técnicas para mapeamento das experiências segundo as diversas perspectivas. Os mesmos conceitos e técnicas descritas por este autor também são utilizados por outros especialistas do meio prático (GIBBONS, 2018; RISDON, 2011).

O quarto autor descrito neste capítulo é o único que não apresenta uma abordagem orientada para a perspectiva do ecossistema do cliente. No entanto, foi selecionado porque sua metodologia de mapeamento, utilizando a técnica de construção de personas para diferenciar as experiências de públicos distintos, também influenciou as escolhas metodológicas desta pesquisa.

\subsubsection{Yu e Sangiorgi (2017)}

A partir de um estudo de casos exploratório em dez projetos de desenho de serviços, os autores propõem um modelo cíclico de desenvolvimento de novos serviços orientado à perspectiva de co-criação de experiências.

Com o intuito de construir uma teoria abrangente e transferível, foram analisados casos de desenvolvimento de novos serviços em variados contextos, conduzidos tanto por agências de desenho internas à organização, quanto por consultorias independentes. A partir deste estudo, o modelo foi proposto envolvendo seis estágios que se conectam de forma cíclica (Figura 1). 
Figura 1 - Modelo de desenvolvimento de serviços orientado para a co-criação de valor

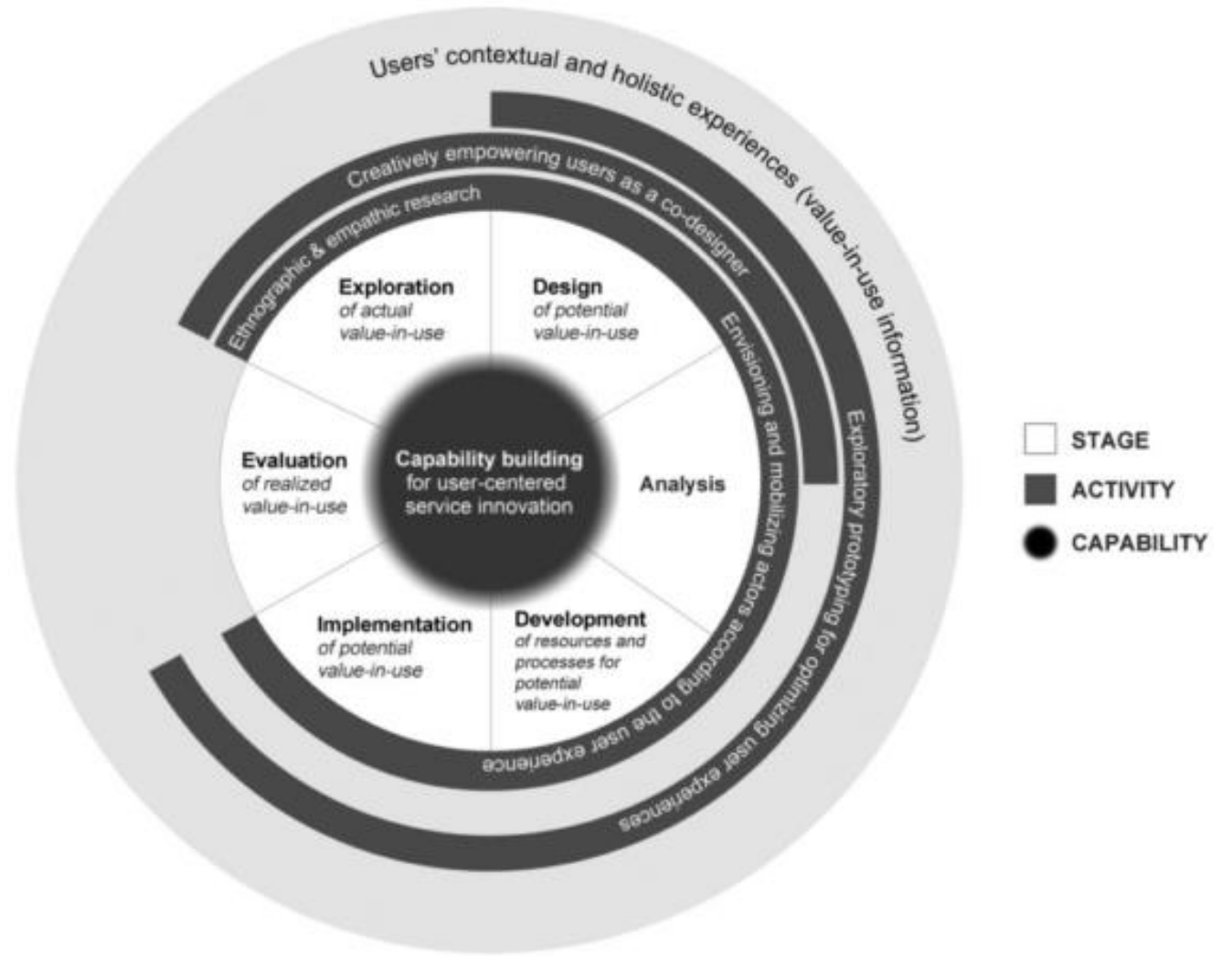

Fonte: Yu e Sangiorgi (2017)

A fase da Exploração é o passo inicial e que envolve o diagnóstico das experiências atuais, direcionando todos os demais estágios do processo de desenvolvimento de novos serviços. As seguintes atividades estão envolvidas nesta etapa:

a) Identificação da experiência contextual e pessoal do cliente como fontes chaves para o desenvolvimento do conceito de serviço;

b) Uso de técnicas etnográficas e empáticas;

c) Diagramas de visualização da experiência holística do cliente, com múltiplos canais e pontos de contato dentro de um sistema de serviço;

d) Identificação dos atores que participam do sistema de serviço;

e) Identificação de desconexões no sistema de serviço e como um novo conceito de serviço poderia superá-las;

As demais etapas do método são: Desenho dos novos serviços através da realização de workshops com a participação de colaboradores e clientes e uso de protótipos explorando experiências do usuário; Análise, que envolve a comunicação do conceito de serviço aos stakeholders e obtenção de suporte e financiamento; Desenvolvimento de recursos físicos e on- 
line, documentação, treinamento e alinhamento das partes interessadas; Por fim, Implementação e Avaliação envolve a medição do impacto dos novos serviços nas experiências dos clientes e a gestão dos serviços.

\subsubsection{Patricio et al. (2011)}

Patricio et al. (2011), propõem um método de desenho de serviços em três níveis. O primeiro nível é o da constelação de valor em que o cliente está inserido, o segundo nível é o da jornada do cliente e o terceiro nível é o do encontro, ou ponto de contato. O nível da constelação de valor equivale ao ecossistema do cliente.

Os autores apresentaram o método multinível em 4 passos: (1) Estudo da Experiência; (2) Desenho do Conceito de Serviço (Constelação de valor); (3) Desenho do Sistema de Serviço da Firma (Jornada) e (4) Desenho do Encontro de Serviço (Ponto de Contato).

\subsection{Estudo da Experiência do Cliente}

O primeiro passo começa com um estudo em profundidade sobre a experiência do cliente em seus diferentes níveis. Métodos qualitativos são utilizados para obter informações e compreender os diferentes níveis da experiência do cliente. Esta etapa envolve técnicas de coleta de dados, como observação, entrevistas em profundidade, grupos focais, testes de usabilidade ou orientações.

O estudo qualitativo permite mapear a atividade geral do cliente, as atividades de serviço e as tarefas de serviço, que estão relacionadas aos diferentes níveis da experiência do cliente. O estudo qualitativo pode ser complementado com métodos quantitativos para avaliar características específicas ou para fazer uma avaliação global da experiência do cliente em um determinado nível. Esse entendimento fornece a base para projetar a oferta de serviços em seus diferentes níveis

\subsection{Desenho do Conceito de Serviço}

O Conceito de Serviço, segundo o método, é definido como o posicionamento da empresa na Constelação de Valor do Cliente (CVC), incluindo os serviços oferecidos e os links e parcerias estabelecidos com outras organizações na rede para aprimorar a proposta de valor da empresa. Portanto, esta etapa se concentra na proposição de valor da empresa, porém em um contexto mais amplo da rede de valor na qual ela está inserida. 
Esta atividade inicia-se por compreender a CVC (Figura 2). A experiência de constelação de valor é co-criada através das interações entre o cliente e todas as organizações de serviço que contribuem com a atividade (objetivo) do cliente, como a compra de uma casa, por exemplo. No nível da CVC, o objetivo é compreender a experiência do cliente para além da visão mais restrita dos serviços da empresa. Os estudos em profundidade com o cliente permitem a decomposição das diferentes atividades e dos fatores mais importantes da experiência (Figura 2). A seguir, a rede de valor é representada como o conjunto de serviços que são oferecidos e suas interrelações representadas. O objetivo do cliente é colocado no centro da rede.

Com base no entendimento ampliado da experiência da $C V C$ e sua decomposição, as ofertas de serviços existentes que respondem pelas necessidades dos clientes são analisadas e as empresas envolvidas podem explorar alternativas para reposicionar seu conceito de serviço e aumentar sua contribuição para a experiência da do cliente.

Figura 2 - Componentes do Desenho de Serviço Multinível

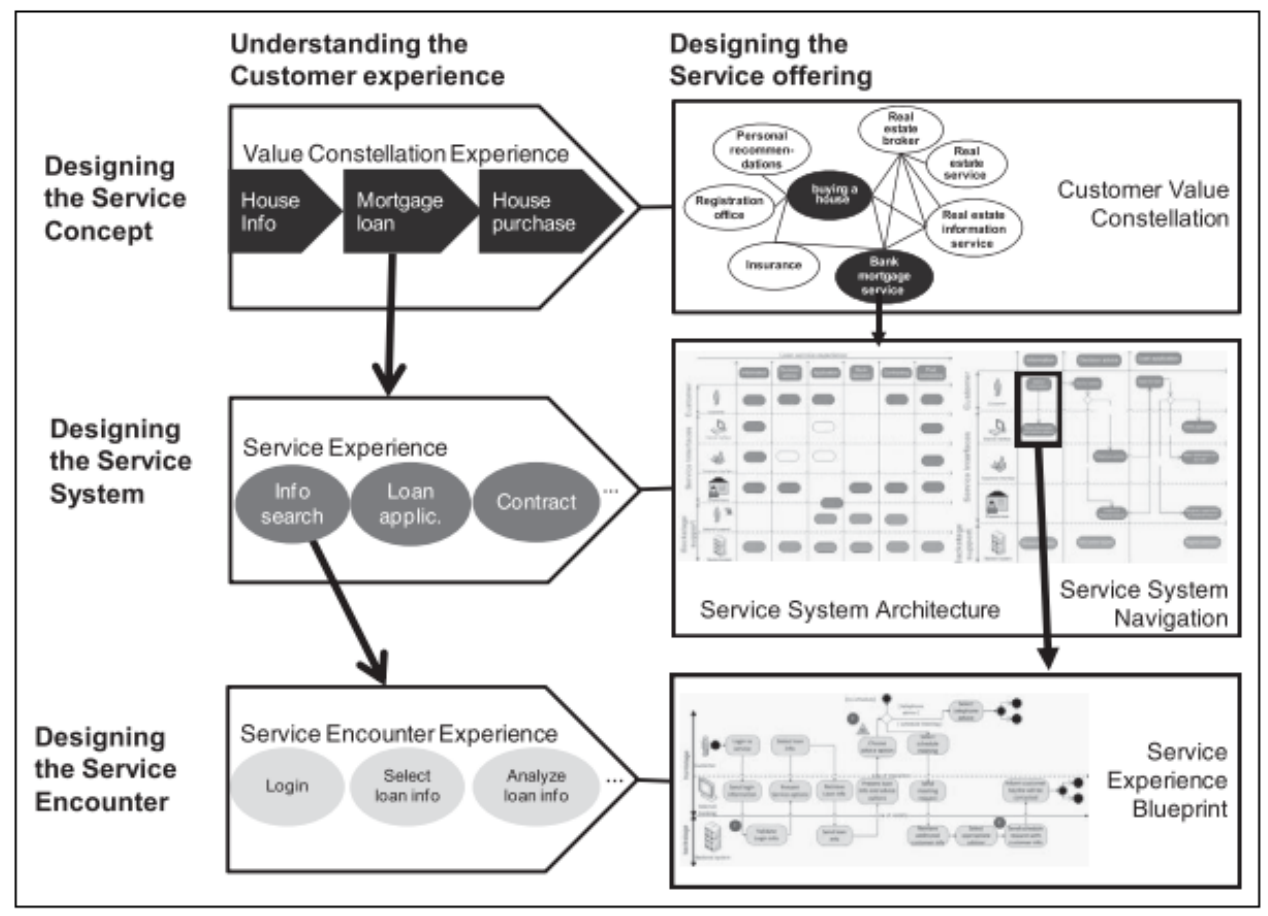

Fonte: Patrício et al. (2011)

\subsection{Desenho do Sistema de Serviço da Firma}

Nesta etapa, a empresa projeta seu sistema de serviços de acordo com o seu posicionamento na CVC. Esta etapa envolve a configurção de pessoas, tecnologias e recursos no nível da firma. Portanto, ela ocorre na perspectiva firma-cliente. 
Esta atividade inicia-se pela decomposição em encontros das atividades do nível da CVC, nas quais a organização decidiu se envolver. Entender esse nível é importante pois revela como os diferentes encontros de serviço irão formar a nova jornada do cliente, os caminhos e interfaces de serviço que os clientes usam e os fatores que permitem ou inibem a experiência de serviço desejada. Para cada tarefa de serviço, o sistema de serviços deve oferecer um mix de interfaces que os clientes podem escolher e navegar suavemente.

\subsection{Desenho do Sistema de Serviço da Firma}

Neste nível, cada momento de interação com o cliente é desenhado. Os projetistas de serviços precisam definir a configuração, o processo de interação e o papel de cada participante.

O método usa o diagrama Blueprint de Serviço para projetar cada encontro concreto. A ferramenta de serviço é utilizada para mapear as ações dos diferentes participantes no encontro de serviço, tanto do pessoal de linha de frente, quanto dos bastidores. O diagrama descreve linhas de interação, linhas de visibilidade, pontos de falha, pontos de espera e links de interface de serviço.

De forma resumida, o método multinível oferece uma visão holística, desde o nível da rede de serviços, passando pelo nível do sistema de serviços multi-interface, até o nível do encontro. As diferentes visões da oferta de serviços podem ser usados por diferentes membros da equipe de desenho ou pelos tomadores de decisão.

\subsubsection{Kalbach (2017)}

Kalbach (2017) aborda técnicas e ferramentas focadas na atividade de mapeamento das experiências. Ele chama estas ferramentas de "Diagramas de Alinhamento" pois argumenta que eles têm a finalidade de engajar os indivíduos com a experiência do cliente. Os diagramas têm dois objetivos, o primeiro é alterar a perspectiva da organização, que passará a enxergar os processos através dos olhos cliente, e o segundo é criar uma visão compartilhada através dos diversos departamentos, o que levará a um alinhamento e consistência nas ações.

O processo de mapeamento que o autor propõe é composto por algumas atividades, que deverão ser seguidas de forma flexível e adaptadas a cada situação: (1) Iniciação do projeto e estruturação do esforço; (2) Pesquisa; (3) Ilustração do diagrama da experiência atual e (5) Utilização do diagrama para alinhamento; 
2.2.1.3.1 Iniciação do projeto e estruturação do esforço

Esta fase envolve definir claramente a intenção do projeto, particularmente quando diversos stakeholders estão envolvidos. As duas questões principais que precisam ser endereçadas nesta fase são os objetivos organizacionais e os tipos de experiência que se deseja mapear.

Os diagramas são mais eficientes quando são coerentes com a estratégia e com os objetivos da organização que está se empenhando no esforço de mapear as experiências. Isto inclui compreender a missão, a proposta de valor, a estratégia de crescimento, os segmentos e quais são as lacunas no conhecimento.

Para determinar quais experiências mapear, pode ser interessante compreender a cadeia de valor do cliente, ou seja, criar uma representação dos principais atores e fluxo de valor para as pessoas. Esta representação pode ser usada para examinar as várias relações possíveis de mapear.

Nesta fase também são escolhidos as técnicas e os diagramas a serem utilizados. Uma técnica que pode ser selecionada é criação de Personas para descrever detalhes sobre um grupo ou segmento de clientes. As Personas são descrições narrativas que refletem os padrões comuns de comportamento, necessidades e emoções (Figura 3). É possível criar Proto-Personas, que não são inicialmente o resultado de uma pesquisa do usuário. Originam-se de workshops de livre debate em que as pessoas da empresa tentam criar descrições sobre quem elas acreditam ser o público alvo. A Persona totalmente pronta pode ser criada mais tarde, depois de concluída uma pesquisa mais profunda. 
Figura 3 - Exemplo de digrama persona

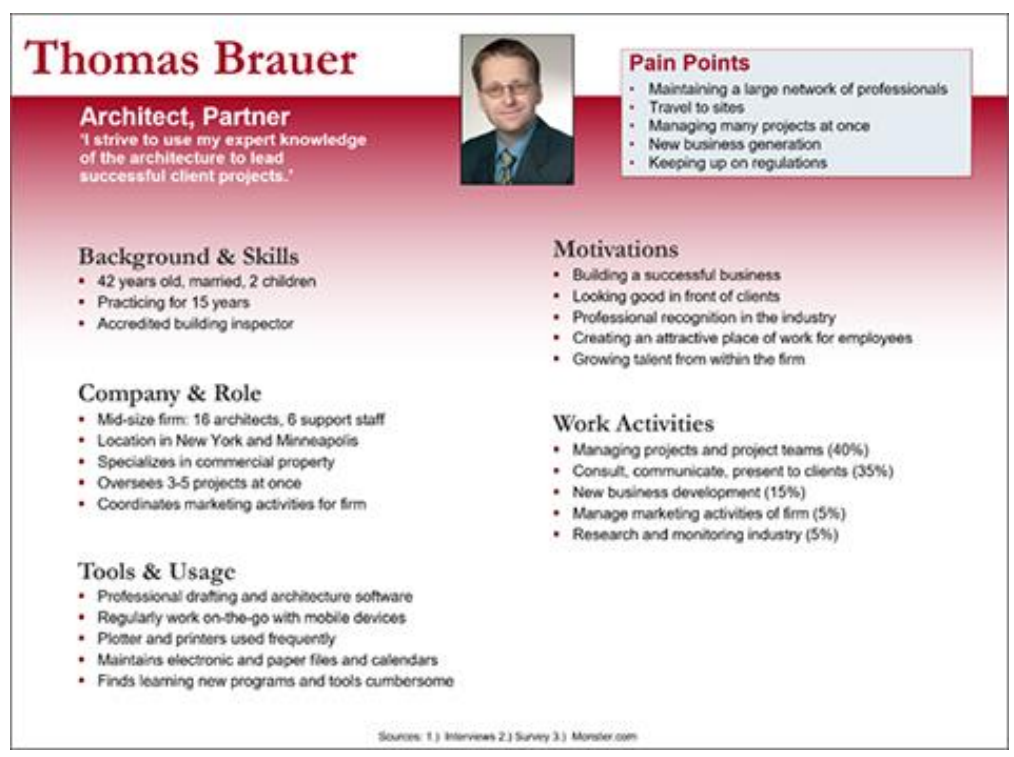

Fonte: Kalbach (2017)

Uma vez compreendidas as relações que se deseja mapear e as Personas, é necessário selecionar os diagramas mais adequados para mapear as experiências. Existem diversos tipos de diagrama: cronológicos, espaciais, hierárquicos ou em rede. Estes serão mais bem detalhados na fase de ilustração das experiências. Qualquer que seja o diagrama, são criadas "junções" maiores, como categorias, fases, divisões. Nos cronogramas cronológicos, as fases são muito utilizadas.

\subsection{Pesquisa}

Esta fase envolve as seguintes atividades: (1) Rever as fontes de informação existentes; (2) Entrevistar stakeholder internos; (3) Criar um mapa preliminar; (4) Realizar uma pesquisa externamente e (5) Analisar os dados. Este processo é interativo e estas etapas não ocorrem de maneira linear.

As fontes existentes podem envolver pesquisas de mercado, relatórios da indústria, documentos internos, mídia social, críticas e classificações. As descobertas são consolidadas em um processo de escolha das partes relevantes e que tragam implicações relacionadas ao objetivo de mapear a experiência.

Durante as entrevistas com stakeholders internos, o objetivo é descobrir o que as pessoas pensam sobre a experiências dos clientes ao interagirem com a organização. Nesta fase é 
possível investigar o fluxo de ações do cliente e como elas acreditam que eles se sentem ao longo do percurso.

Um diagrama preliminar da experiência pode ser construído com base nas informações coletadas, o que guiará uma futura pesquisa. Ele ajudará a organizar as ideias e a guiar as possíveis perguntas.

A pesquisa externa foca em entrevistas e observações qualitativas. Perguntas abertas sobre a experiência individual poderão ajudar a preencher as lacunas no conhecimento. Entrevistas e observações no local fornecem uma interação pessoal com os participantes e permite conhecer o seu ambiente. Contudo, em algumas situações, também é viável fazer entrevistas remotas por telefone ou videoconferência.

Análises quantitativas podem complementar a pesquisa. Escalas são úteis para indicar a intensidade com que alguns aspectos são experimentados. Por exemplo, para avaliar a frequência com a qual as fases ou etapas são experimentadas ou compreender a importância de determinado ponto de contato ou, ainda, saber a satisfação em cada ponto de contato.

\subsection{Ilustração do Diagrama da Experiência Atual}

A tarefa nesta é etapa é compilar os dados em uma única história coerente. Os diagramas das experiências atuais são imagens agregadas das pessoas e das organizações investigadas. Os mapas preliminares podem ajudar a direcionar a consolidação. As anotações e gravações deverão então ser organizadas e estruturadas. De cada entrevista, são extraídas as descobertas relevantes e agrupadas por tema. É necessário encontrar padrões comuns para criar uma única narrativa de cada grupo.

Para descrever a experiência, os elementos mais utilizados são ações, pensamentos $e$

sentimentos. É possível incluir citações diretas ou incorporar fotos. Ao formatar o conteúdo, é necessário conseguir expressar as informações através de uma linguagem visual e de forma compacta, ou seja, selecionar quais ideias serão incluídas, quais serão destacadas e criar um todo coerente. Elementos gráficos são utilizados. Um dos recursos mais utilizados são linhas para dividir, conter, conectar e mostrar caminhos. Cores ajudam a criar uma sensação de prioridade e facilita a compreensão geral. Ícones gráficos são bons para comunicar muitas informações em pequenos espaços, além de criar interesse visual.

O autor classificou os diagramas em cinco tipos: 
a) Mapa da Jornada do Cliente - Podem ser mais úteis para visualizar os estados emocionais durante as interações ao longo do processo de compra. Analisam como o cliente se encaixa no serviço. A ênfase está nos estados cognitivos e emocionais da pessoa, momentos da verdade e satisfação. Está mais alinhado com a visão diádica firma-cliente.

b) Blueprint de Serviço - Mostra como um serviço, geralmente um encontro em tempo real, é experimentado pelo cliente. A ênfase está nas evidências físicas, nos canais, nos processos de apoio e nos fluxogramas. Também adota a perspectiva de como o cliente se encaixa no serviço.

c) Mapa da Experiência - Vê a pessoa como um ator se comportando no contexto de uma atividade mais ampla. A ênfase está nos comportamentos, nos objetivos, Jobs to be done. Geralmente inclui ações, pensamentos, sentimentos e pontos críticos. Geralmente focam numa atividade humana geral em determinado domínio. A empresa pode até não ser declarada explicitamente no mapa ou pode haver muitas organizações envolvidas. Eles ajudam a mudar o pensamento coletivo da organização de recursos ou processos para os resultados desejados que os clientes buscam.

d) Mapa Espacial - Pessoa como parte de um sistema de interação multifacetado. Destaca o fluxo de informações e as relações entre os vários aspectos e componentes de um sistema. Inter-relações em um ecossistema. Inclui perspectivas de vários atores e diversos tipos de interações com a organização.

e) Diagrama do Modelo Mental - tem suas raízes na psicologia e se refere ao processo de pensamento de uma pessoa sobre como o mundo funciona, sua estrutura e realidade. São construções cognitivas baseadas em crenças, suposições e experiências passadas. É uma percepção da pessoa sobre como o sistema funciona, não necessariamente como ele realmente funciona.

Os diagramas mais usados, segundo o autor, são o Blueprint de Serviço, o Mapa da Jornada e o Mapa da Experiência, que apresentam uma estrutura cronológica. O diagrama do Blueprint de Serviços e o da Jornada do Cliente focam em como o cliente se encaixa nos serviços da organização e, por isso, estão mais relacionados com a visão diádica firma-cliente.

Abaixo, alguns destes modelos são ilustrados: 
Figura 4 - Exemplo de um blueprint de serviço

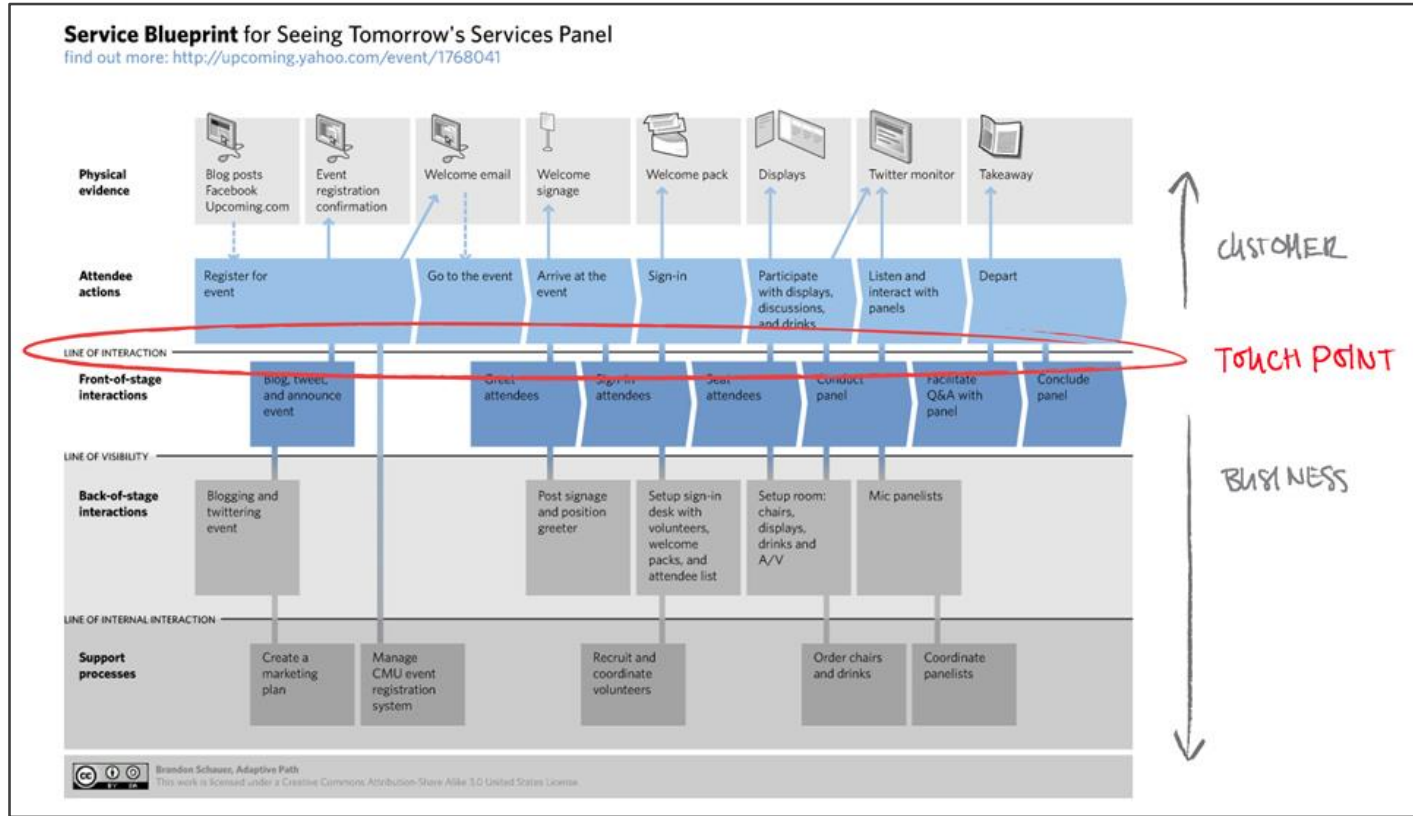

Fonte: Jim Kalbach, (2011)

Alguns diagramas apresentam a Persona no topo, como é visto no exemplo de mapa da jornada da Figura 5.

Figura 5 - Exemplo de mapa da jornada com a representação da persona no topo.

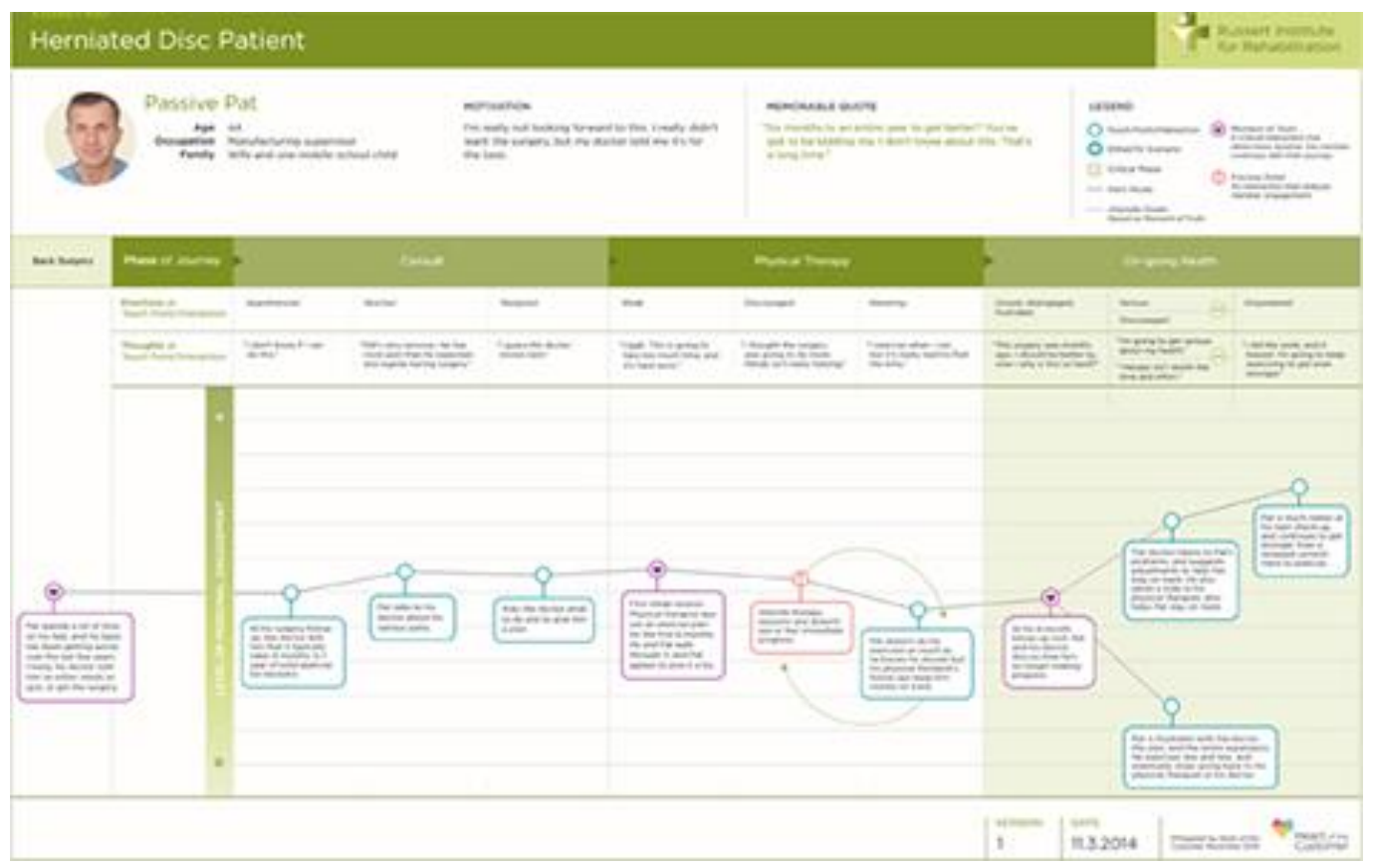

Fonte: Kalbach (2017)

A Figura 6 representa um exemplo de mapa da experiência de uma mulher grávida ao longo das semanas de gestação criado por Beth Kyle. 
Figura 6 - Exemplo de mapa da experiência de gravidez

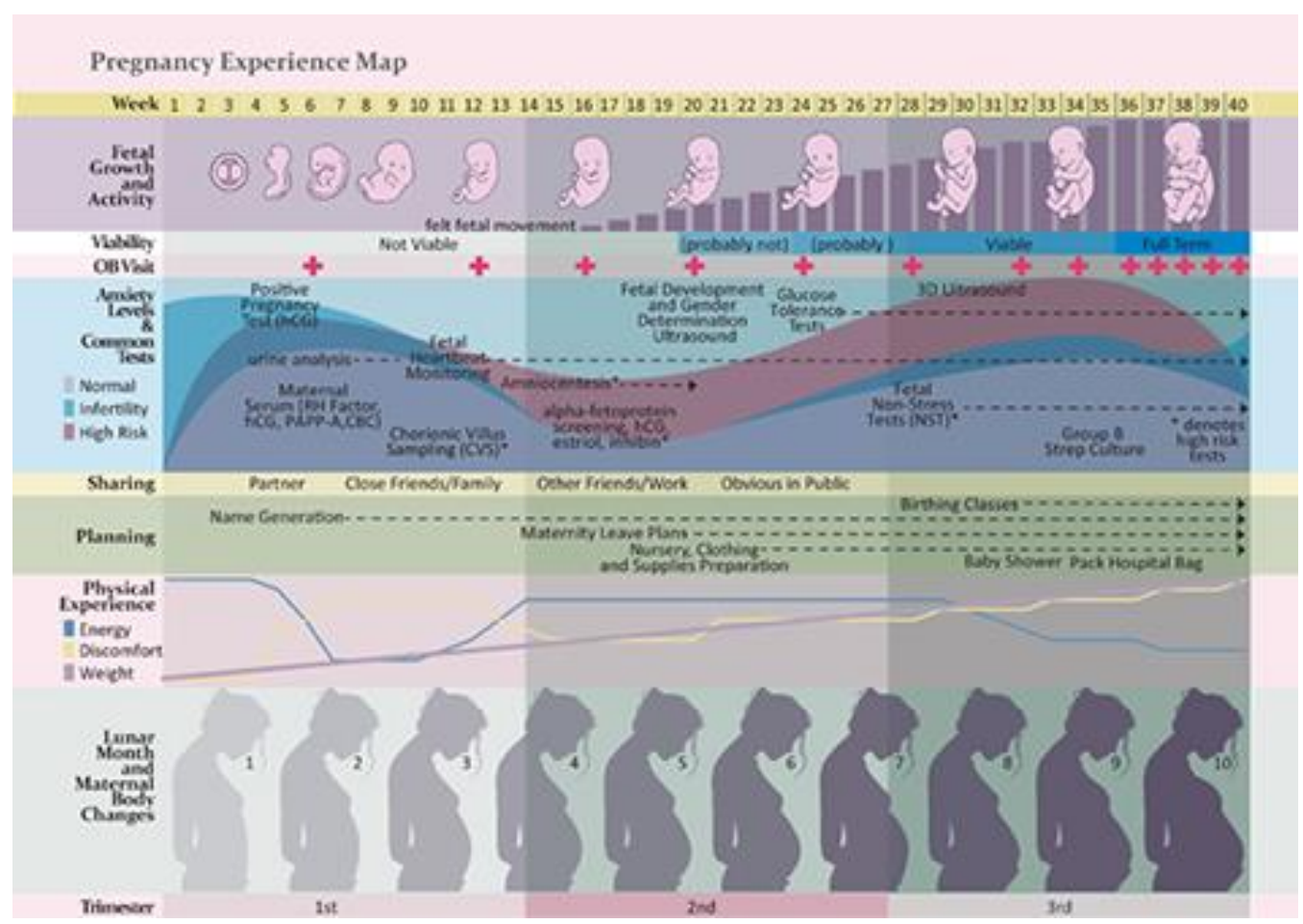

Fonte: Kalbach (2017)

\subsection{Utilização dos Diagramas para Alinhamento}

Segundo o autor, o objetivo de criar o diagrama não é o fim, mas um meio para engajar as pessoas, fornecendo uma imagem maior, para que elas sejam capazes de enxergar as experiências do cliente como um todo.

Um workshop de alinhamento pode ser organizado com três objetivos: (1) Criar Empatia, ou seja, conseguir uma visão "de fora para dentro" sobre a experiência, (2) Prever, imaginando um futuro que forneça valor significativo e (3) Avaliar, que seria articulação de ideias para serem testadas rapidamente.

\subsubsection{Trischler e Zehrer (2011)}

Trischler e Zehrer (2012) descrevem em seu artigo o método qualitativo utilizado para mapear a experiência de clientes em um parque temático na Austrália. O método envolve quatro etapas: (1) Construção da Persona para caracterizar os diferentes públicos do parque, (2) Técnica de Observação (Shadowing), (3) Entrevistas semiestruturadas e (4) Mapeamento das Jornadas das Personas. 


\subsection{Construção de Personas}

A partir das características dos públicos alvo, crianças e adolescentes, criam-se personagens que irão guiar as decisões relacionadas ao desenho dos serviços. Cada Persona é tipicamente representada com uma fotografia, um nome, descrição e detalhes sobre interesses específicos e comportamentos relevantes;

Cinco crianças e sete adolescentes foram selecionadas aleatoriamente do banco de dados do parque. Os perfis de Persona foram derivados de entrevistas com usuários. Os resultados foram agrupados em informações sobre rotinas diárias, preferências, motivações e frustrações e fontes típicas de informações usadas pelas pessoas selecionadas.

A Figura 7 ilustra a construção de uma persona para representar as crianças.

Figura 7 - Construção de persona que representa o segmento criança

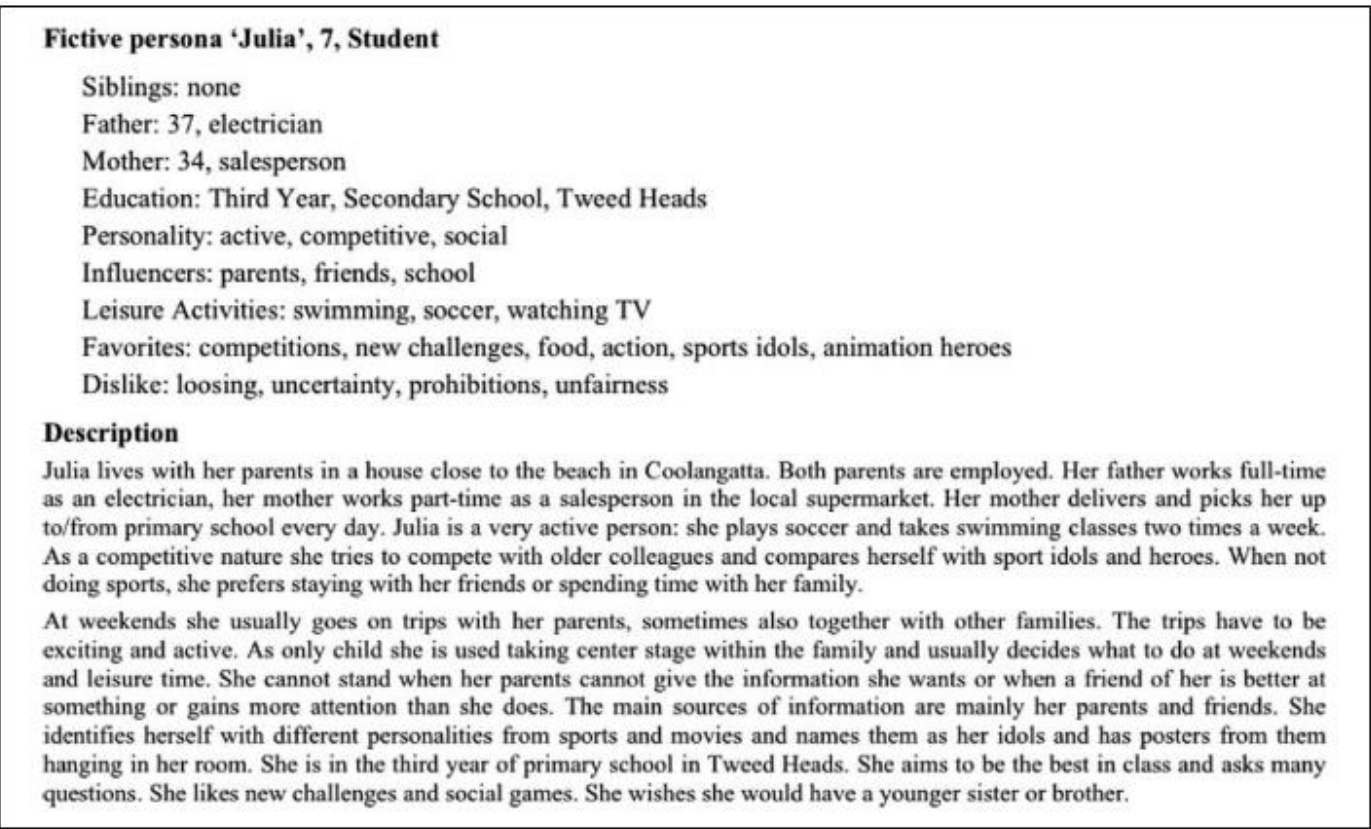

Fonte: Trischler e Zehrer (2012)

\subsection{Observação}

As crianças e adolescentes convidados para participar da pesquisa foram acompanhados ao longo da experiência no parque. O observador focou nas emoções, linguagem corporal e sentidos, tendo em mente uma clara representação da persona previamente construída;

Durante a observação, foram feitas anotações sobre quais serviços o observado utilizou, quanto tempo ele passou nas diferentes atrações do parque temático, como suas reações e linguagem corporal mudaram, e quais interações tiveram com funcionários. 
Os dados foram transcritos para planilhas, usando uma linha de tempo, bem como examinando e descrevendo os pontos de contato durante a jornada de experiência de serviço

\subsection{Entrevistas Guiadas}

O propósito das entrevistas foi revelar motivações subjacentes, crenças, atitudes e sentimentos encontrados durante a observação. O questionário incluía técnicas de sondagem para garantir que as informações fornecidas pelo participante tivessem sido corretamente compreendidas.

As entrevistas duraram entre 45 e 65 minutos. Todas as entrevistas foram transcritas na íntegra e revisadas para identificar padrões referentes a fontes de expectativas, desencadeadores de satisfação e insatisfação e ações pós-serviço.

\subsection{Técnica de Visualização}

O mapa da jornada do cliente foi a ferramenta utilizada para articular as percepções obtidas a partir dos dados coletados e para reter a empatia como uma maneira de manter os dados "vivos" durante o processo. Todos os pontos de contato foram identificados durante a experiencia no parque temático, incluindo os pontos de contato antes após o período. Foram utilizados símbolos (++), (+), (-) e (--) para representar o humor e o grau de satisfação das pessoas observadas ao longo dos estágios do consumo do serviço.

A figura 8 representa o mapa da jornada construído para a persona que representa as crianças. 
Figura 8 - Jornada da persona Julia

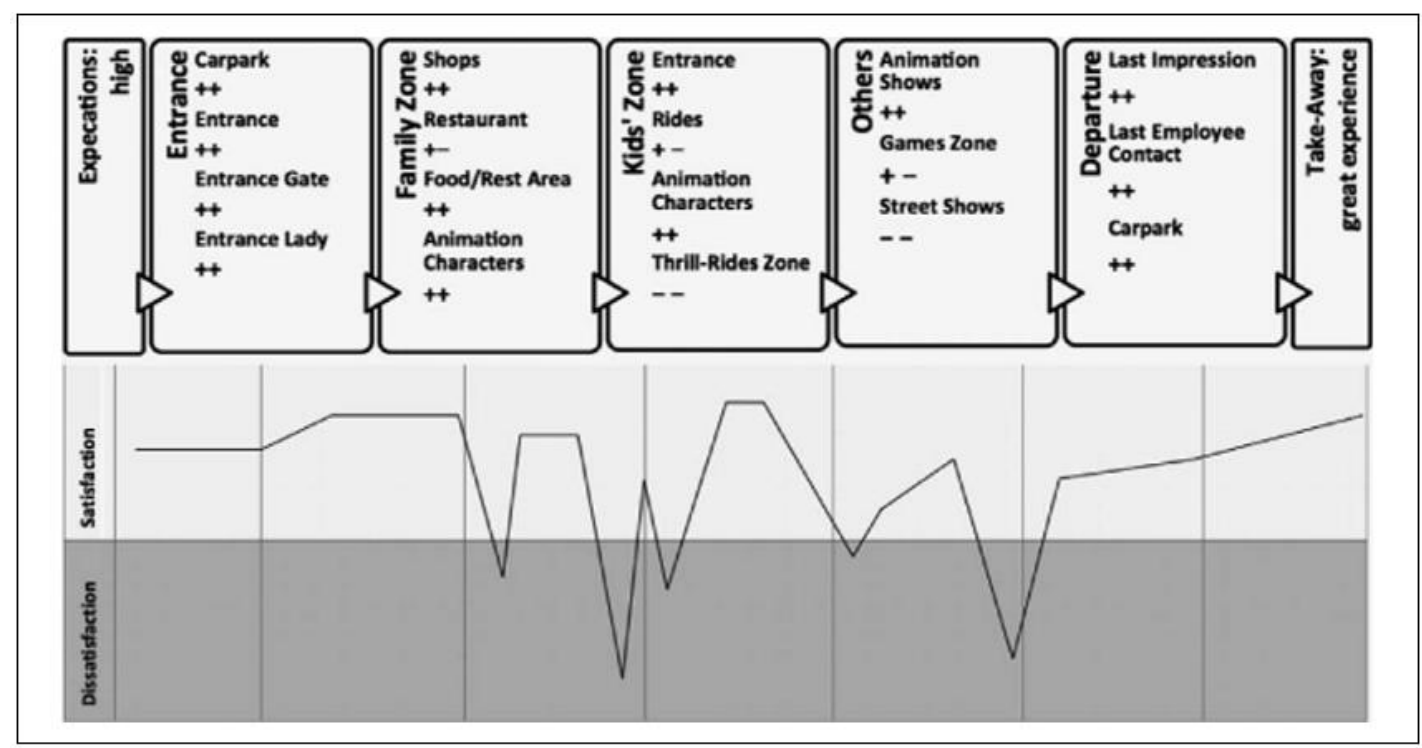

Fonte: Trischler e Zehrer (2012)

Os resultados demonstram que enquanto a Persona Julia, que representa o segmento de crianças, ficou encantada com a sua experiência, a Persona David, que representa os adolescentes, após algumas horas no parque, ficou entediado e no final ficou insatisfeito. Ao final do trabalho, o autor concluiu que este método qualitativo proporcionou uma visão holística e significativa sobre os clientes, provendo insights profundos sobre suas experiências. 


\section{ASPECTOS METODOLÓGICOS}

Os procedimentos metodológicos adotados para atingir o objetivo deste trabalho se basearam nas referências de técnicas e ferramentas descritas no capítulo anterior sobre Diagnóstico da Experiência do Cliente.

As abordagens descritas se mostram pertinentes para compreender a amplitude e a complexidade do ecossistema do produtor de cana-de-açúcar, composto por inúmeras atividades, decisões e interações. Técnicas qualitativas de coleta de dados e métodos de visualização são recomendados para compreender a complexidade e a intangibilidade das experiências das pessoas. Este enfoque permite gerar insights profundos sobre como os clientes experimentam o serviço e visualizar os seus processos. (KALBACH, 2017; TRISCHLER; ZEHRER, 2012; YU; SANGIORGI, 2018).

Os autores citados influenciaram este estudo nos seguintes aspectos:

Yu e Sangiorgi (2017) apontam para o uso de técnicas etnográficas e empáticas para compreender a experiência contextual do cliente. Além disso, recomendam o uso de técnicas de visualização dentro de um sistema de serviços, com identificação dos atores que participam dele. Por fim, ele recomenda que sejam identificadas as desconexões dentro deste sistema de serviços.

Patricio et al. (2011) influenciaram na construção da abordagem metodológica deste trabalho ao apresentarem um método de mapeamento da experiência que inclui o nível da constelação de valor, que pode ser entendido como o nível do ecossistema do cliente. Estudos em profundidade através de métodos qualitativos permitem a decomposição das diferentes atividades para alcançar seu objetivo, assim como a identificação dos atores que participam da rede de serviços. Com base no entendimento ampliado da experiência, as empresas envolvidas na constelação de valor podem explorar alternativas para reposicionar seu conceito de serviço e aumentar sua contribuição para a experiência do cliente.

As abordagens e técnicas de Kalbach (2017) contribuíram em diversos aspectos com a proposição metodológica desta pesquisa. Ele recomenda que o primeiro passo seja o esclarecimento da intenção do projeto da experiência, identificando com quais aspectos da estratégia organizacional este esforço irá contribuir. A técnica de construção de Personas utlizada para diferenciar as experiências dos distintos públicos também se mostrou pertinente para alcançar os objetivos deste estudo. Os diversos tipos de diagramas apresentados pelo autor, que podem ser adotados para diferentes propósitos, incluindo orientações sobre o layout e elementos que podem ser utilizados, serviram de referências importantes neste trabalho. 
Trischler e Zehrer (2012), embora não adotem a perspectiva do ecossistema do cliente, influenciaram este trabalho em função de seu método que inclui o mapeamento das experiências para distintos públicos, utilizando-se da técnica de construção de Personas. Outra referência foi a técnica de visualização através de uma curva para representar os pontos altos e baixos ao longo dos estágios da experiência.

\subsection{Tipo de Pesquisa}

Quanto aos fins, esta é uma pesquisa exploratória. Segundo Mattar (2005), um estudo exploratório pode ter o objetivo de formular um problema ou hipóteses para uma investigação mais exata, mas também pode ser adotado com a intenção de aumentar o conhecimento do pesquisador acerca de um fenômeno que deseja investigar em estudo posterior, mais estruturado. Neste sentido, esta pesquisa se propõe, a partir de uma metodologia relativamente recente e ainda em evolução, conhecer com mais profundidade os fenômenos envolvidos nas experiências dos produtores de cana-de-açúcar. Espera-se, desta forma, que sejam avaliados os procedimentos adotados e esclarecidos os aspectos relevantes que poderão fazer parte do roteiro de uma investigação futura, com uma base ampliada.

A natureza desta pesquisa é qualitativa. A maioria das informações para compreender e descrever experiências origina-se de coletas qualitativas, pelo fato de gerarem descrições ricas em detalhes do Porquê e Como, e não dados quantitativos do Quanto (KALBACH, 2017). Análises qualitativas favorecem a interpretação da situação que se deseja estudar através de técnicas que buscam descrever, decodificar, traduzir e, dessa forma, aprender o significado e não a frequência de certos fenômenos (DONALD R. COOPER, 2003).

Neste estudo foram adotados três procedimentos metodológicos: (1) utilização de dados secundários para identificar, mapear e descrever os processos e as atividades realizadas pelos produtores de cana-de-açúcar. (2) entrevistas semiestruturadas para obtenção dos insights profundos dos produtores e (3) diagramas de visualização para mapear as experiências.

Dados secundários são aqueles coletados anteriormente para propósitos diferentes do problema de pesquisa específico. Na grande maioria dos casos são informações de obtenção mais rápida, mais acessível e mais barata do que os dados primários (RÉVILLION, 2003). Os dados secundários utilizados neste estudo incluíram trabalhos científicos, teses e dissertações, reportagens de revistas especializadas, além de relatórios e websites de instituições governamentais, órgãos de pesquisa e organizações do setor. 
A técnica de entrevistas semiestrturadas foi escolhida por permitir certo grau de comparação entre as entrevistas, já que fazem uso de um guia que será aplicado de forma mais ou menos constante, admitindo uma flexibilidade que permite seguir o curso de pensamento do participante. (FLICK, 2009; DONALD R. COOPER, 2003). Segundo Révillion (2003, p. 24), a principal característica dos métodos em investigações exploratórias é a flexibilidade. "Conforme a pesquisa avança, o pesquisador deve ficar alerta no sentido de reconhecer as interrelações entre as informações que são levantadas, buscando novas ideias.”.

O terceiro procedimento foi a utilização de diagramas de visualização para mapear experiências. Este tipo de técnica tem a intenção de criar uma visão ampla e compartilhada sobre a perspectiva do cliente, mudando o modelo mental das pessoas, redirecionando o foco dos processos internos para os processos do cliente. O diagrama selecionado foi o Mapa da Experiência, que adota a perspectiva do ecossistema do cliente, reconhecendo suas interações múltiplos atores, produtos e serviços (KALBACH, 2017).

\subsection{Etapas da Pesquisa}

A pesquisa foi estruturada em 6 etapas:

1. Esclarecimento da intenção

2. Mapeamento dos processos do produtor de cana-de-açúcar

3. Entrevistas em profundidade

4. Criação das Personas

5. Mapeamento das experiências no nível do ecossistema de cada entrevistado

6. Identificação de oportunidades envolvendo os atores do setor

\subsubsection{Alinhamento da intenção}

Antes de iniciar um projeto de mapeamento da experiência, é necessário definir claramente a intenção e selecionar diagramas coerentes com a estratégia e com os objetivos da organização que está se empenhando no esforço de mapear as experiências dos seus clientes (KALBACH, 2017).

Foram realizadas duas reuniões de alinhamento com o gestor executivo da Orplana com o intuito de compreender os principais desafios do setor, conhecer as diretrizes e projetos estratégicos da organização e definir de que forma a metodologia de gestão da experiência do cliente poderia contribuir com o plano de gestão em curso da organização. 


\subsubsection{Mapeamento dos processos dos produtores}

Uma das técnicas mais utilizadas para mapear experiências é decomposição dela em etapas e atividades (KALBACH, 2017; PATRICIO et al., 2011). Este mapeamento pode ocorrer após a realização da fase da pesquisa com o cliente, mas também pode ser realizado preliminarmente para guiar as próximas etapas da pesquisa (KALBACH, 2017). Neste trabalho, optou-se pela segunda opção, ou seja, criar uma visão inicial da experiência, a partir do mapeamento preliminar dos processos, que pudesse guiar o planejamento das entrevistas.

Com este fim, o primeiro passo foi a realização de uma pesquisa ampla na literatura que envolveu a leitura de materiais de trabalhos acadêmicos, além de conteúdos de revistas especializadas e websites do setor.

A partir deste primeiro entendimento, foram identificados os macroprocessos de produção, comercialização e gestão, que foram desdobrados em subprocessos e atividades. A proposta inicial foi levada para a apreciação do gestor executivo e das assessoras das áreas agrícola e de gestão da associação que seria envolvida na pesquisa. Ajustes foram realizados até que o material estivesse pronto para a próxima etapa da pesquisa.

\subsubsection{Levantamento das percepções dos produtores}

Sob a perspectiva do ecossistema do cliente, o foco da gestão da experiência está nos processos que o cliente realiza para alcançar seus objetivos (HEINONEN et al., 2010; HEINONEN; STRANDVIK, 2015). Desta forma, as entrevistas foram estrturadas de forma a possibilitar a compreensão das experiências dos produtores ao longo dos processos que eles percorrem para alcançar seus objetivos.

O roteiro foi estruturado de forma a começar pela identificação dos seus objetivos com o negócio de produção e fornecimento de cana-de-açúcar. A partir deste foco, o mapeamento dos processos, realizado preliminarmente, foi utilizado como guia das entrevistas, de forma a ir capturando as percepções dos produtores ao longo das múltiplas atividades realizads para alcançar seus objetivos.

O roteiro ${ }^{4}$ foi estruturado em três blocos:

Bloco 1 - Levantamento de informações iniciais com vistas à identificação de características básicas sobre as propriedades e sobre o negócio. As informações são importantes para

\footnotetext{
${ }^{4}$ Vide Guia das entrevistas no Apêndice B
} 
caracterizar os perfis dos produtores e possibilitar a comparação das experiências. As seguintes perguntas fizeram parte do roteiro.

- Qual é a localização da (s) sua (s) propriedade (s)?

- Quantos hectares ela (s) têm?

- Qua é a sua Produtividade média na última safra?

- Você tereceiriza alguma atividade?

- Para qual(is) usina(s) você fornece?

- Você é o principal responsável pela gestão da sua propriedade ou você conta com o apoio de outros gestores ou técnicos para auxiliar na tomada de decisão?

Bloco 2 - Identificação dos objetivos de negócio

- Quais são seus objetivos com o negócio de produção e fornecimento de cana-de-açúcar?

Bloco 3 - Levantamento das percepções ao longo dos processos:

- Durante o processo quais são seus os principais desafios?

- Quais métodos você utiliza para realizar as atividades?

- Você conta com o apoio de algum serviço, produto ou tecnologia para realizar estas atividades?

- Em que pontos você considera que suas necessidades não são atendidas? E em quais pontos você está satisfeito?

As perguntas foram utilizadas como ponto de partida e como forma de cobrir todas as etapas da experiência. No entanto, elas não ocorreram de forma linear. Com intuito de ganhar profundidade e identificar novos pontos latentes da experiência, à medida que o entrevistado trazia algum aspecto novo, ele tinha a liberdade de aprofundar o depoimento. A partir da primeira pergunta, que foi aberta, buscou-se capturar os aspectos previstos nas demais perguntas ao longo do depoimento. Caso o entrevistado não mencionasse alguma das atividades mapeadas ou algum dos aspectos previstos no roteiro, tais questionamentos seriam realizados pelo pesquisador.

Todas as entrevistas foram realizadas com produtores associados à Socicana, associação da região de Guariba, pertencente à rede da Orplana. Esta decisão foi impulsionada por alguns motivos. Um dele é a localização geográfica, que facilita a locomoção do pesquisador até o 
local do entrevistado. Outra razão é que esta associação conta com perfis variados de produtores, desde pequenos, que terceirizam a maior parte de suas operações, até grandes produtores, totalmente verticalizados.

Um terceiro fator, que também propiciou o desenvolvimento do trabalho junto à Socicana, foi o fato de a associação estar promovendo programas de capacitação que visam o desenvolvimento técnico e gerencial dos seus associados. Ao selecionar produtores que participam destes programas, esperava-se obter percepções mais ricas à respeito dos métodos produtivos, tecnologias e ferramentas de gestão.

Foi feita a solicitação à associação de convidar produtores de perfis diversificados quanto ao grau de verticalização e quanto ao porte. Inicialmente, 8 produtores aceitaram participar da pesquisa. Três não conseguiram participar por motivos pessoais. Portanto, esta pesquisa foi concluída com a participação de cinco produtores de perfis diversificados.

O tempo de duração das entrevistas variou de 1 h 30 min a 2 h. No entanto, durante o processo de análise dos dados, percebeu-se a necessidade de solucionar algumas dúvidas. Novas entrevistas presenciais ou por telefone foram realizadas, com duração de aproximadamente 30 min a 1 h. No caso de um dos produtores, foi pertinente contatar o engenheiro agrônomo da propriedade para esclarecer dúvidas relacionadas à etapa produtiva.

Observações no local da experiência também foram utilizadas como fonte de dados. Houve a oportunidade de realizar uma visita de aproximadamente três horas na propriedade de um dos grandes produtores, onde foi possível ampliar as percepções sobre os seus processos produtivos. Foram vistos talhões com plantações em diferentes estágios, viveiros de produção de MPB, linhas de MEIOSI, intercaladas com culturas de rotação, áreas de preservação ambiental, oficina de máquinas etc.

\subsubsection{Análise dos dados}

Todas as entrevistas foram gravadas e transcritas na sua integralidade. Os depoimentos coletados foram classificados de acordo com a fase do processo e a atividade à qual estivesse relacionada.

Após a análise comparativa das percepções dos cinco entrevistados, foi possível identificar aspectos comuns e distintos entre os entrevistados. Para cada fase do processo, foi construído um quadro com o resumo das percepções positivas e negativas identificados. 


\subsubsection{Criação das personas}

A técnica de construção de Personas é bastante utilizada durante o processo de mapeamento das experiências. Pode ser necessário mapear experiências diferentes para distintos grupos de pessoas. A técnica de construção de personas envolve descrições narrativas que refletem os padrões comuns de comportamento, necessidades e emoções de um determinado perfil (KALBACH, 2017; TRISCHLER; ZEHRER, 2012).

Durante a análise dos dados foi possível identificar diferenças entre os perfis entrevistados, e também entre suas experiências. Desta forma, considerou-se pertinente a utilização da técnica de criação de personas para representar os perfis e mapear distintas experiências.

É importante destacar que as personas criadas neste trabalho não representam a totalidade da população, já que foram construídas a partir de uma base pequena de entrevistados. Segundo Kalbach (2017) é possível criar personas de suposição ou personas de provisão até que uma pesquisa mais ampla seja realizada. Desta forma optou-se por criar personas de forma preliminar. Os aspectos de diferenciação identificados neste estudo podem ser utilizados em futuras pesquisas, com bases ampliadas de entrevistas, possibilitando um aprimoramento dos resultados, assim como a identificação de novas Personas.

Para a construção das personas as instruções descritas por Kalbach (2017) foram seguidas. A Identificação dos atributos mais destacados que distinguem um perfil do outro foi realizada através da análise comparativa dos dados coletados durante as entrevistas.

Foram construídas três personas. Cada uma reúne características semelhantes de dois ou três produtores. Cada persona foi representada com uma fotografia, um nome, alguns dados demográficos e a descrição dos atributos de diferenciação identificados na pesquisa.

\subsubsection{Mapeamento das Experiências e Identificação de Oportunidades}

Existem diferentes tipos de diagramas que podem ser utilizados para ilustrar as experiências (KALBACH, 2017). O diagrama Mapa da Experiência foi selecionado para ilustrar a experiência do produtor de cana por adotar uma perspectiva mais ampla do contexto do cliente.

A ênfase não está em ver como o cliente se encaixa no serviço de uma determinada organização, como é o caso do Mapa da Jornada ou do Blueprint de Serviços. Os mapas da experiência reconhecem que as pessoas interagem com muitos produtos e serviços a partir de vários provedores e muitas situações (Kalbach, 2017). Outro fator que levou a esta escolha, é 
que o Mapa da Experiência adota uma visão cronológica ou sequencial da experiência, o que se mostrou pertinente, considerando a possibilidade de mapear as experiências ao longo dos processos dos produtores.

Um mapa da experiência foi ilustrado para cada Persona construída.

A ferramenta de diagramação utilizada foi o Lucidchart ${ }^{5}$.

Diversos elementos podem ser ilustrados no mapa da experiência. Optou-se por incluir neste trabalho os seguintes:

a) Fases e atividades;

b) Identificação dos métodos, tecnologias e serviços utilizados pelos produtores em cada atividade;

c) Curva dos níveis da experiência ao longo dos processos. As subidas e decidas são mostradas com o passar do tempo e representam o grau de satisfação ou insatisfação expressados durante as entrevistas. Este estilo de linha representando tornou-se uma convenção no mapeamento da experiência. Em geral, são estimadas de modo intuitivo pelo entrevistador. (Kalbach, 2017);

d) Pensamentos e sentimentos expressados em cada ponto da curva, apresentados no mapa na forma de citação.

e) Identificação de oportunidades para que os atores que participam do ecossistema do produtor, incluindo os próprios produtores, possam repensar suas ações e suas interações e melhorar a competitividade da cadeia sucroenergética.

\footnotetext{
${ }^{5}$ https://www.lucidchart.com/pages/pt/tour-do-produto-lucidchart
} 


\section{ALINHAMENTO DA INTENÇÃO}

O alinhamento da intenção do trabalho, junto à Orplana, está relacionado à definição dos próprios objetivos de pesquisa deste projeto, descritos no capítulo da Introdução.

Durante as reuniões iniciais realizadas com o gestor executivo da Orplana, identificouse que a utilização da abordagem de mapeamento da experiência do cliente poderia complementar os esforços de implementação do plano de gestão da organização.

A missão da Orplana é "Garantir um futuro seguro e rentável para os produtores de canade-açúcar, buscando excelência na produção agrícola e coordenação da cadeia sucroenergética" (ORPLANA, 2019).

Para alcançar este propósito, o plano de gestão da organização está orientado para desenvolver uma comunidade profissionalizada de produtores de cana, através de sinergias e ações coletivas, tanto entre produtores, como entre os agentes que constituem a cadeia de valor da cana ${ }^{6}$.

Compreender a heterogeneidade do mundo dos produtores é uma das estratégias da Orplana. A existência de diferentes níveis tecnológicos e gerenciais entre os produtores pode revelar caminhos elevar a eficiência do setor.

Informações relacionadas ao porte das unidades produtivas já são quantificadas e classificadas segundo o diagrama da Figura 9:

Figura 9 - Critérios de classificação dos produtores de cana-de-açúcar por porte

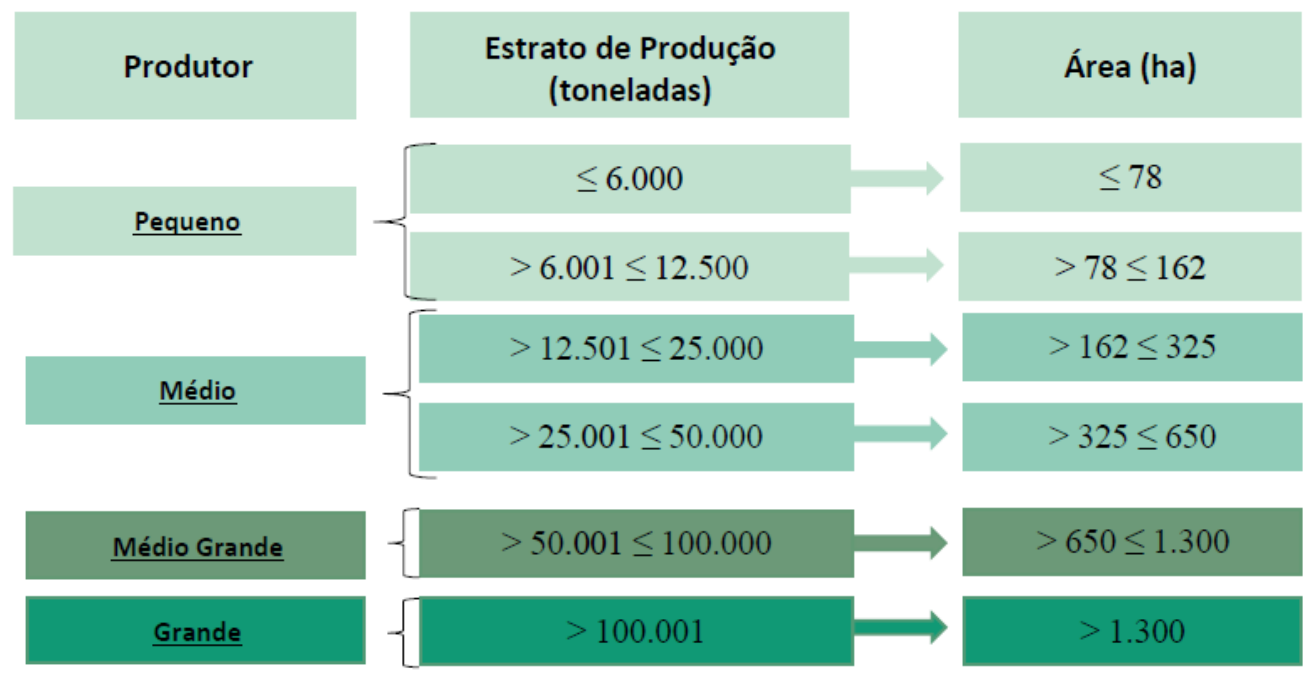

Fonte: Gestão Executiva Orplana

\footnotetext{
${ }^{6}$ Informações fornecidas pela Gestão Executiva da Orplana
} 
Conforme a Figura 10, a maior concentração de produtores $(88,5 \%)$ registrados no Sistema ATR na safra 2017/18 está nos estratos de produção de até 125 mil toneladas ano, respondendo por $23,30 \%$ da produção. Já os médios e grandes produtores, que juntos representam apenas $11,5 \%$ da população, respondem por $76,6 \%$ da produção.

Figura 10 - Estratificação dos produtores registrados no sistema ATR da região centro-sul do Brasil

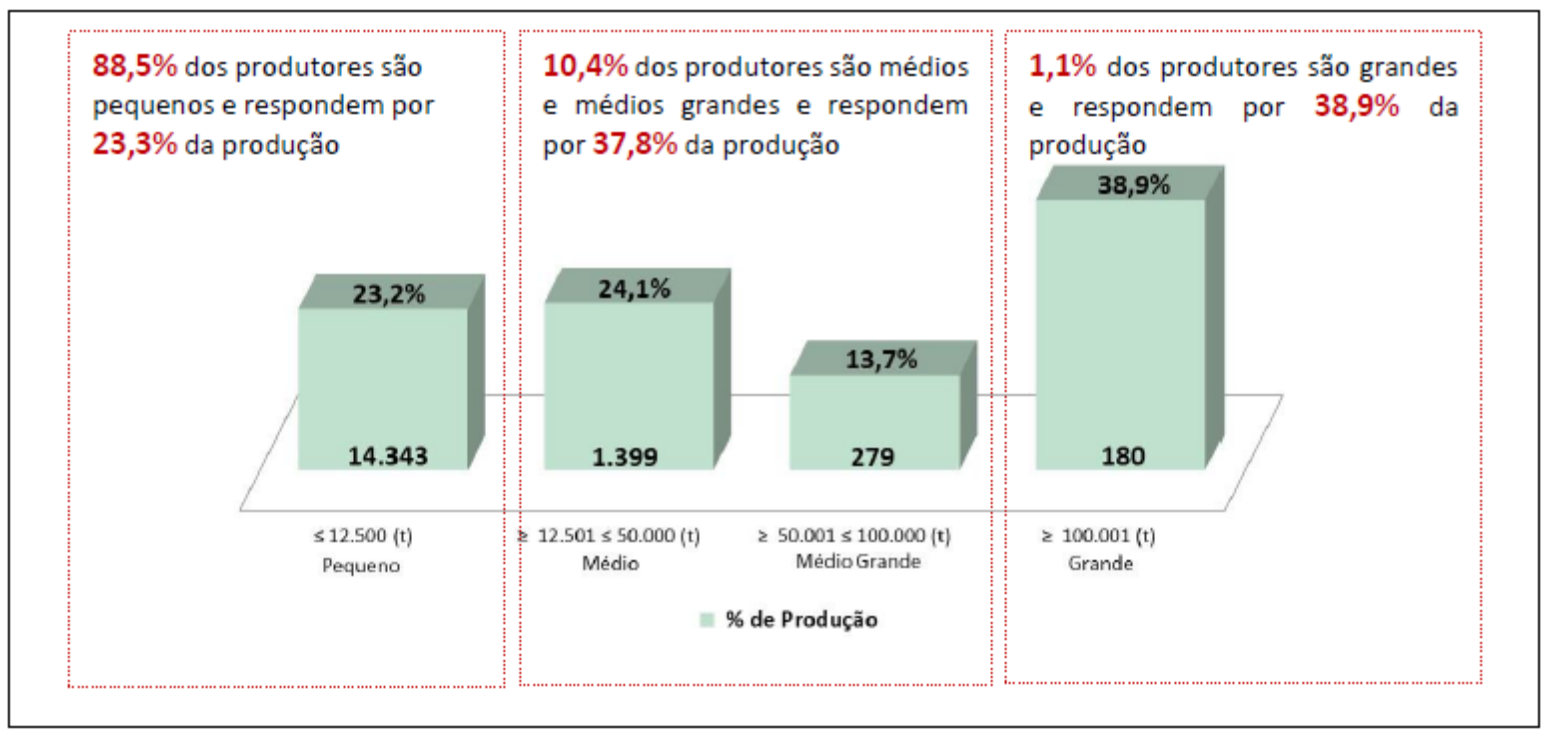

Fonte: Gestão Executiva Orplana

Além das características relacionadas ao porte, existem especificidades na realização das operações nas diversas fases da cultura, desde o plantio até a colheita. Um dos projetos da Orplana tem o objetivo de estratificar e caracterizar diferentes perfis e conhecer as distintas realidades dos produtores de cana-de-açúcar localizados na região Centro-Sul, bem como, analisar a eficiência econômica e produtiva dos distintos sistemas de produção ${ }^{7}$.

Dentro do projeto, um estudo sobre a eficiência operacional dos distintos sistemas de produção de cana adotados por produtores e por usinas foi realizado em parceria com o Instituto de Pesquisa Educação Continuada em Economia e Gestão de Empresas (PECEGE). A partir de uma base apurada e padronizada de custos de produção, foi realizada uma análise comparativa da eficiência das diferentes modalidades produtivas ${ }^{8}$.

Os sistemas de produção adotados pelos produtores independentes foram classificados segundo o seu grau de verticalização da seguinte forma:

\footnotetext{
${ }^{7}$ NEVES et al., Segmentação e Análise da Eficiência Técnica e Econômica de Produtores de Cana-de-Açúcar na Região Centro/Sul. Ribeirão Preto, 2018. (Projeto de pesquisa / ainda não publicado).

${ }^{8}$ Informações fornecidas pela Gestão Executiva da Orplana
} 
Figura 11 - Identificação dos segmentos de produtores de cana-de-açúcar segundo o nível de verticalização

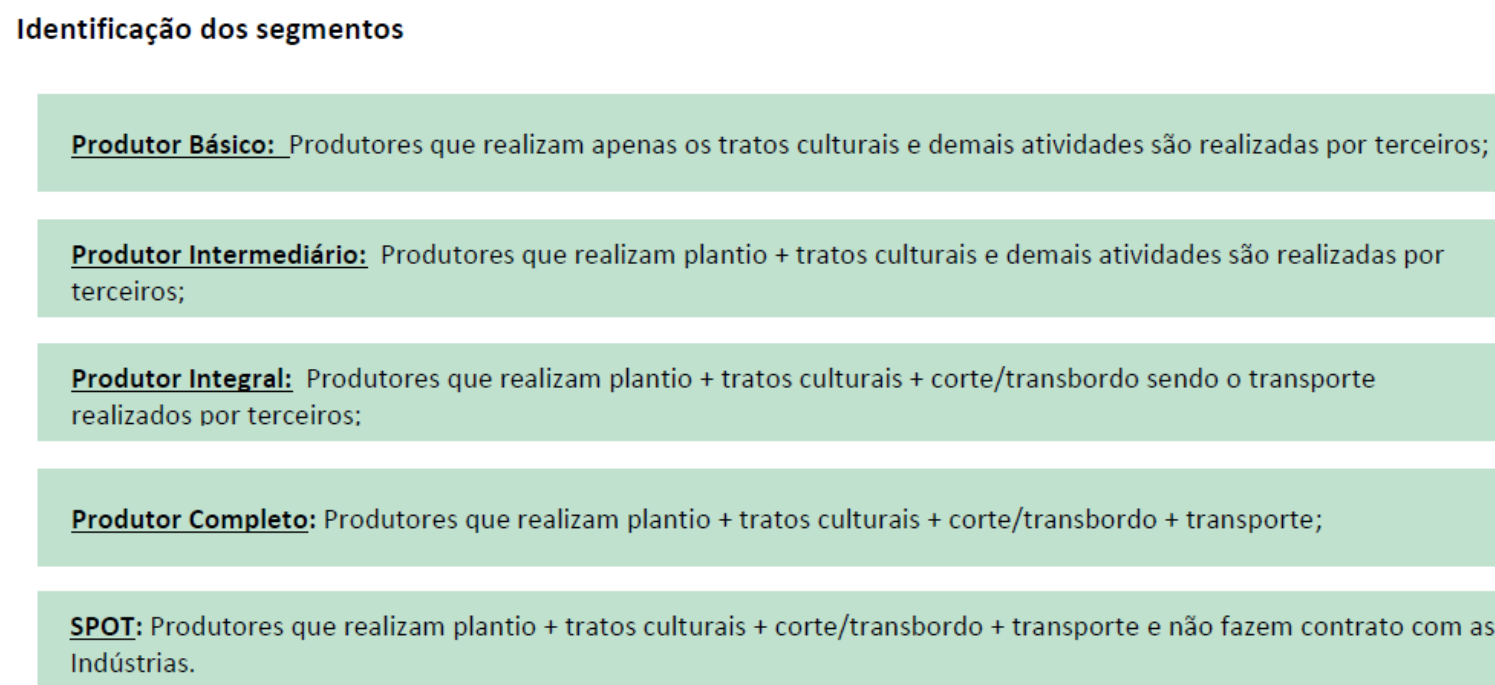

Produtor Integral: Produtores que realizam plantio + tratos culturais + corte/transbordo sendo o transporte realizados por terceiros:

Produtor Completo: Produtores que realizam plantio + tratos culturais + corte/transbordo + transporte;

SPOT: Produtores que realizam plantio + tratos culturais + corte/transbordo + transporte e não fazem contrato com as Indústrias.

Fonte: Gestão Executiva Orplana

Os resultados deste estudo, apresentados na Figura 12, indicam que, quanto maior o controle e o domínio das operações pelo produtor, maior será a sua eficiência e menos oneroso será o custo final da cana produzida e entregue na esteira para a usina.

No lado esquerdo do gráfico, é possível comparar os custos de produção realizados pelas usinas nos seus diferentes modelos de utilização da terra e, no lado direito, a mesma comparação ocorre para os diferentes níveis de controle das operações pelos produtores. É possível perceber a queda do custo cana esteira, representado pela linha marrom, à medida que ela se move para a direita do gráfico. Desta forma, quanto maior o grau de verticalização dos produtores, maior será o seu domínio sobre os processos e menos oneroso será o custo final da cana na esteira da usina. Conclui-se então que, com a migração das operações de produção de cana das usinas para os produtores, ambos podem sair ganhando? ${ }^{9}$

\footnotetext{
${ }^{9}$ Informações fornecidas pela Gestão Executiva da Orplana
} 
Figura 12 - Análise comparativa da cana adquirida pela indústria conforme sua origem, custo final, graus de eficiência e controles operacionais.

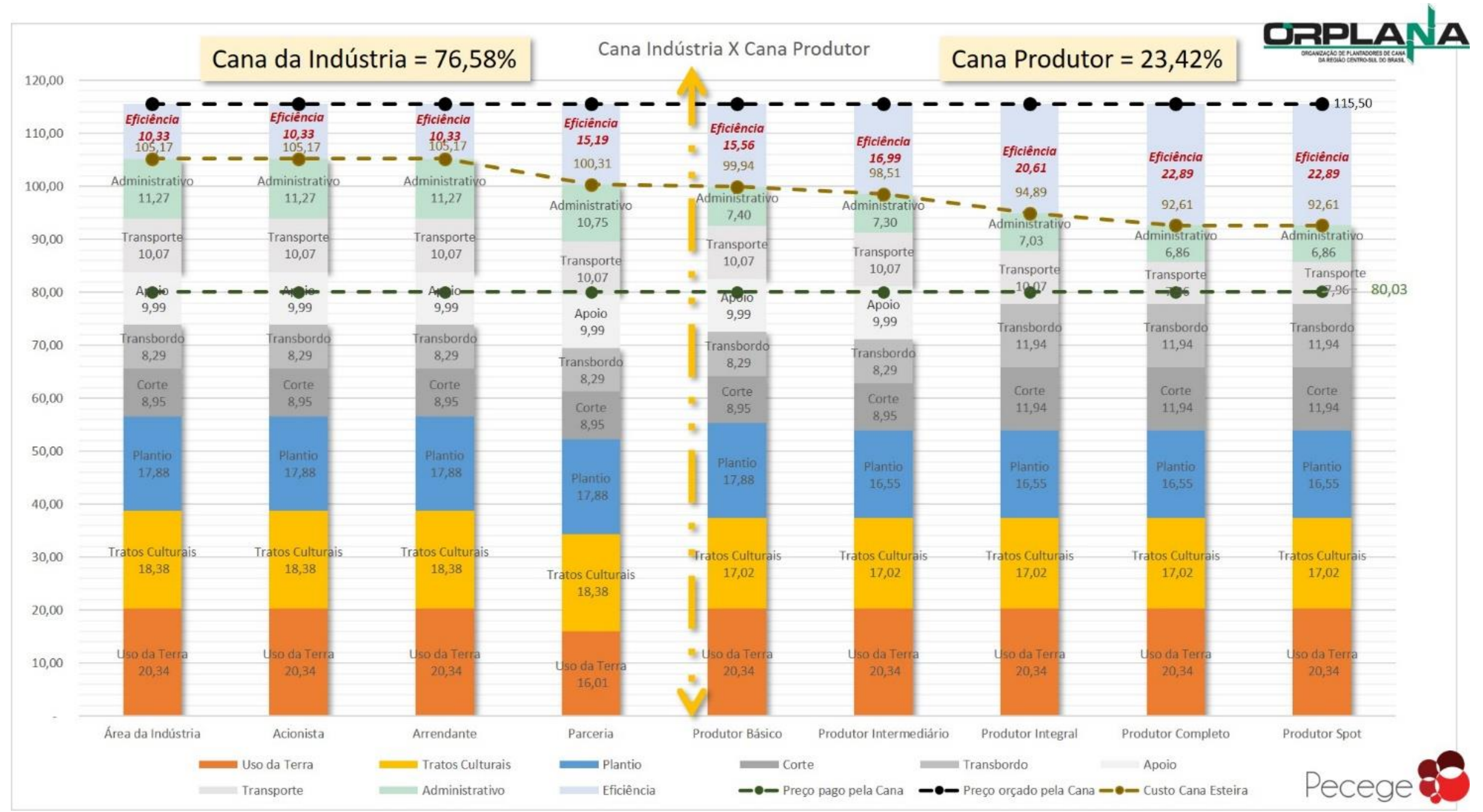

Fonte: Gestão Executiva Orplana 
Outra frente de trabalho está buscando, através de um levantamento por meio de questionários, identificar a representatividade destes perfis de produtores na região centro-sul do Brasil, além de compreender outras características, como perfil da propriedade, níveis tecnológicos, relacionamento com as usinas etc.

Após a compreensão dos desafios e das estratégias da organização para conhecer de maneira ampla e profunda o universo dos produtores de cana-de-açúcar, verificou-se que as abordagens identificadas na literatura para diagnosticar a experiência do cliente poderiam contribuir com este esforço.

A partir de técnicas qualitativas e visuais, o mapeamento das experiências na perspectiva do ecossistema produtor de cana-de-açúcar, possibilitaria a criação de uma visão ampla e completa sobre contexto em que produtores de diferentes portes e níveis de verticalização estão inseridos, propiciando a identificação de oportunidades envolvendo os múltiplos agentes do setor. 


\section{MAPEAMENTO DOS PROCESSOS DOS PRODUTOR}

Uma vez esclarecida a intenção do projeto, a primeira etapa da pesquisa seria realizar um mapeamento dos processos do produtor de cana-de-açúcar, que serviria para identificar o escopo e a abrangência das suas experiências.

A partir de uma revisão da literatura foram mapeados os macroprocessos de Produção, Comercialização e Gestão (Figura 13), que foram desdobrados em processos e atividades.

As principais fontes utilizadas para estruturar os processos produtivos foram o Manual de Custos e Indicadores do Setor da Bioenergia (INSTITUTO DE ECONOMIA AGRÍCOLA DO ESTADO DE SÃO PAULO (IEA); UNIÃO DOS PRODUTORES DE BIOENERGIA (UDOP), 2016) e o trabalho acadêmico Produção de Cana-de-Açúcar: Do Planejamento do Plantio à Colheita (ALBERTON, 2012).

Cada etapa do processo será descrita nas subseções deste capítulo. 
Figura 13: Mapeamento dos processos do produtor de cana-de-açúcar

Processos de Produção

Planejamento
Agrícola
- Determinação da
vocação técnica
do ambiente
- Planejamento da
época do plantio
- Planejamento da
época da colheita

\section{Organização de$$
\text { Recursos }
$$

- Dimensionamen-

to de

equipamentos

- Planejamento e

compra de

insumos

- Levantamento de

recursos

financeiros

\section{Processo de \\ Comercialização}

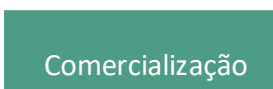

- Contrato de

fornecimento

- Modelo de

precificação

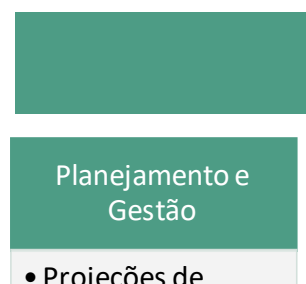

- Projeções de

Resultados

- Acompanhamento

e gestão dos

resultados

\begin{tabular}{l} 
Produção de \\
Mudas \\
- Sistema \\
convencional \\
- MPB \\
- Meiosi \\
- Cantosi \\
\hline
\end{tabular}

Conservação e Preparo do Solo

- Sistematização do

solo

- Correção do solo

- Preparo do solo

(n)

\begin{tabular}{l} 
Plantio \\
- Corte das mudas \\
- Carregamento e \\
transporte \\
- Sulcação \\
- Distribuição nos \\
sulcos \\
\hline
\end{tabular}

Processos de Gestão do Negócio

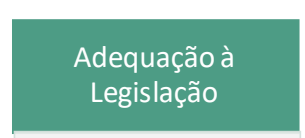

- Adequações

ambientais

- Adequações

trabalhistas

- Certificações

socioambientais

\section{Governança e Sucessão}

- Estrutura de

gestão, regras e

funções definidas

- Processo

sucessório
Atuação Integrada

-Associativismo

- Ações coletivas

- Economia do

compartilhamento entre produtores
Tratos Culturais

- Enleiramento

- Escarificação

- Aplicação de

adubo no solo

\section{- Controle}

fitossanitário
CCT

- Corte

- Carregamento

- Transporte

Fonte: Elaborado pelo autor 


\subsection{Processos de Produção}

\subsubsection{Planejamento Agrícola}

A cana-de-açúcar é uma planta perene. Após o plantio são realizados de três a seis cortes até que seja necessário fazer o replantio para evitar perdas de produtividade. A atividade de planejamento auxilia o produtor na tomada de decisões ao longo de todo este ciclo produtivo com o objetivo da otimização dos resultados.

O planejamento da implantação de um canavial envolve as seguintes decisões: determinar qual variedade de cana-de-açúcar se adaptará melhor ao ambiente de produção (solo + clima) do talhão a ser reformado, determinar em que período deve ser plantada e em qual período será realizada a colheita. Finalmente, a partir das estimativas de produção e período de realização das atividades, o produtor irá dimensionar os recursos necessários para a implantação do canavial.

\subsubsection{Determinação da Vocação Técnica do Ambiente de Produção}

Para obter altas produtividades, a cultura da cana-de-açúcar é extremamente dependente das interações com os ambientes de produção (ARANTES, 2015).

Para determinar a melhor combinação entre ambiente e variedade, existem tecnologias de mapeamento da fertilidade do solo e caracterização do ambiente de produção. $O$ ambiente de produção é determinado pelo conjunto de fatores que compõem a formação de determinado solo e suas interações com o clima da região, através das condições físicas, químicas, morfológicas e hídricas, associadas ao manejo de variedades adequadas para determinados ambientes (ARANTES, 2015). Esse conhecimento contribui para a eficiente alocação das variedades de cana-de-açúcar em função das diferenças genéticas.

Além da adaptabilidade da variedade ao ambiente, recomenda-se que os canaviais sejam plantados com um número relativamente grande de variedades, o que ajuda a prevenir prejuízos com infestações de pragas. Uma área muito grande cultivada com uma variedade suscetível a determinada praga pode submeter a lavoura a grande risco econômico (BRAGA JUNIOR et al., 2018). Segundo (MILLER, 2008a), nunca uma das variedades deve superar $20 \%$ de toda a área plantada. Variedades em estágio de avaliação devem sempre estar presentes e recomenda-se que elas ocupem algo entre 3 a 5\% da área total cultivada. 


\subsubsection{Planejamento da Época de Plantio}

A escolha da época de plantio é fundamental para o bom desenvolvimento da cultura da cana-de-açúcar, que necessita de condições climáticas ideais para se desenvolver e acumular açúcar. A cana necessita de alta disponibilidade de água, temperaturas elevadas e alto índice de radiação solar. São três os sistema de plantio de cana-de-açúcar: sistema de ano-e-meio, sistema de ano e plantio de inverno (ROSSETTO; SANTIAGO, 2009a)

No sistema de ano-e-meio (cana de 18 meses), a cana-de-açúcar é plantada entre os meses de janeiro e março. A fase de maturação ocorrerá a partir do mês de abril do ano seguinte. Este período de plantio é considerado ideal para o plantio da cana-de-açúcar, pois apresenta boas condições de temperatura e umidade, garantindo o desenvolvimento das gemas, possibilitando a brotação rápida e reduzindo a incidência de doenças nos toletes (ROSSETTO; SANTIAGO, 2009a)

No sistema ano, a cana-de-açúcar pode ser plantada no período de outubro a novembro (cana de 12 meses). As vantagens deste sistema estão relacionadas à possibilidade de adoção de uma segunda época de plantio em grandes propriedades, otimizando máquinas e mão-deobra. Porém, este sistema de plantio deve ser adotado de forma restrita devido às seguintes desvantagens: menor produtividade, uma vez que tem apenas sete ou oito meses de crescimento efetivo; pouco tempo para o preparo do solo; e, em algumas situações e para variedades floríferas, a utilização de inibidores de florescimento pode ser necessária (ROSSETTO; SANTIAGO, 2009a)

Com o uso da torta de filtro que contém cerca de 70 a $80 \%$ de umidade, aplicada no sulco de plantio, é possível plantar a cana-de-açúcar mesmo no período de estiagem. A torta fornece a umidade necessária para a brotação. Se ainda for feita uma fertirrigação com vinhaça, ou mesmo irrigação, o plantio da cana pode ocorrer praticamente o ano todo (ROSSETTO; SANTIAGO, 2009a).

\subsubsection{Planejamento da Época da Colheita}

Para maximizar a produção, as variedades de cana-de-açúcar plantadas devem ser colhidas em seu melhor momento de produtividade. Este momento em que a concentração de sacarose é máxima é chamado de pico de maturação (CAVERSAN, 2017).

A concentração de sacarose é uma característica específica de cada variedade. Pelo fato de a safra ser normalmente subdividida em três terços, convencionou-se denominá-las de precoces, médias e tardias. Desta forma, a colheita seria planejada para ser iniciada pelas 
variedades do tipo precoce, seguida e até certo ponto com concomitância pelas variedades médias e tardias. Entretanto, é possível interferir no comportamento das variedades para melhorar ou acelerar a concentração de sacarose em determinadas variedades através de produtos químicos com esta propriedade (MILLER, 2008a)

Portanto, um aspecto importante no planejamento da colheita é o conhecimento da curva de maturação, que corresponde a uma representação gráfica do ciclo de vida da cana. Essa curva pode ser encontrada em função da Polaridade (POL) e do tempo até o corte, podendo ser dividida em duas fases. A primeira fase é a de crescimento vegetativo, em que a planta acumula energia na forma de sacarose, aumentando o valor do POL. Na fase seguinte a planta utiliza a energia acumulada no período anterior para a reprodução da espécie. Neste período, ocorre o decréscimo o valor do POL (SILVA et al., 2011) A Figura 12 ilustra uma curva de maturação.

Figura 14 - Ilustração de uma curva de maturação

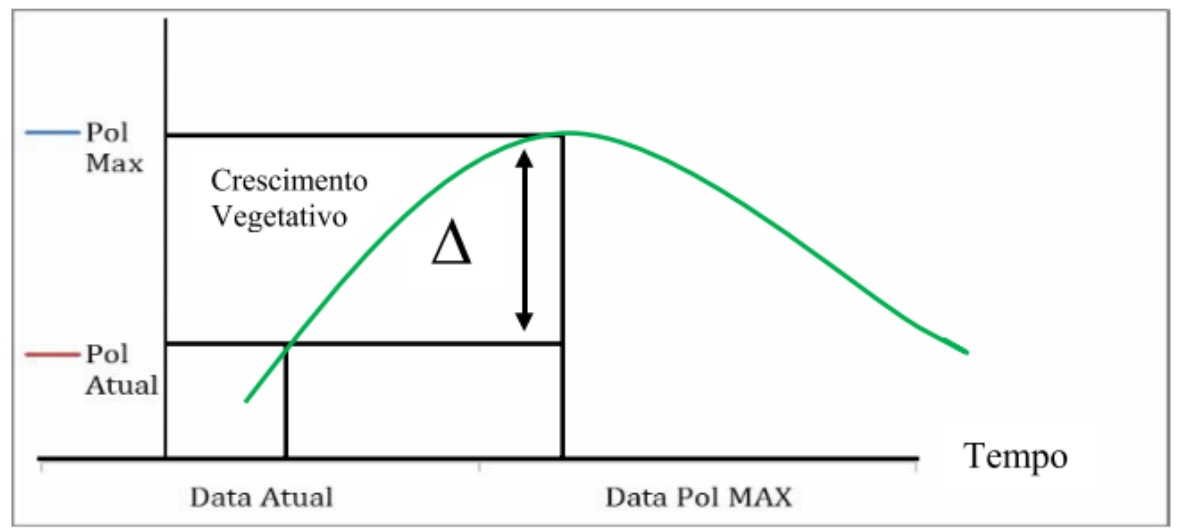

Fonte: Silva et. al 2011

Quanto ao planejamento da época da colheita, embora o ideal seja a sua realização no pico máximo de maturação, é importante destacar que existem restrições técnicas das usinas sucroenergéticas que precisam atender demandas de produção durante todos os meses do ano, além de possuir uma delimitação na capacidade de moagem do maquinário (CAVERSAN, 2017). Para caracterizar em que período a cana pode ser processada, as usinas criaram o Período Útil de Industrialização (PUI), que estabelece POL \% cana $=13 \%$ como satisfatório para o processamento de diferentes variedades (SILVA et al., 2011).

Para conseguir-se a otimização da colheita é necessário realizar um planejamento através da ordenação dos talhões por idade dos canaviais e em cada uma das idades agrupar áreas (talhões) conforme as variedades utilizadas no cultivo destes locais, segundo as suas curvas de maturação de cada uma delas. A decisão de colheita, neste caso, irá possibilitar que sejam 
colhidos canaviais em suas devidas idades e no momento em que cada variedade apresentar o melhor conteúdo de sacarose (MILLER, 2008a).

É possível adotar modelos matemáticos para auxiliar nas tomadas de decisão sobre plantio e colheita visando maximizar a produção. A modelagem auxilia nas tomadas de decisão relacionadas a determinar, para cada talhão, qual variedade de cana-de-açúcar será produzida e em que período deve ser plantada e colhida, de acordo com as curvas de produtividade de sacarose da cana-de-açúcar (BEAUCLAIR, 2004; CAVERSAN, 2017). Tais modelos podem levar em conta inclusive uma flexibilização no período da colheita da variedade de cana plantada para se adequar às restrições de processamento das usinas (CAVERSAN, 2017).

\subsubsection{Organização de Recursos}

Sendo o planejamento da colheita otimizado ou não, a partir das estimativas de produção e época da colheita, o produtor irá dimensionar os recursos necessários e planejar o sequenciamento de operações no campo (SCARPARI, 2002).

A formação das estimativas de produção para a safra é tarefa inerente ao planejamento operacional da colheita, pois define a forma de utilização dos recursos necessários, cuja quantificação depende da acuidade das estimativas. (Beauclear, 2004).

Além da escolha das variedades, o que vai determinar a quantidade possível de cortes são fatores como o manejo do solo e de água, clima, tratos culturais e outros. É necessário adaptar as práticas de plantio ao ambiente e às variedades selecionadas. Existem variedades piores ou melhores para o plantio mecânico, por exemplo. Para outras, é necessário mais ou menos terra na cobrição da muda (CARTA, 2017).

Os mapas com classificação de ambientes de produção facilitam o planejamento agrícola, indicando as operações necessárias para que ocorra um manejo adequado da camada arável em relação às práticas conservacionistas do solo, ações corretivas, adubação, utilização de resíduos das agroindústrias (torta de filtro e vinhaça), controle de pragas e ervas daninhas (ARANTES, 2015)

Portanto, considerando as escolhas durante a fase do planejamento, relacionadas à seleção das variedades, épocas de plantio e colheita, será necessário definir quais as práticas de manejo serão adotadas no ano safra e organizar os seguintes recursos: máquinas e implementos necessários para a realização das atividades, além de planejar e comprar os insumos associados à produção.

A mobilização dos recursos financeiros é outro fator de planejamento que o produtor precisa gerenciar, tanto para investir na reforma, quanto para custear a produção. 


\subsubsection{Produção de Mudas}

Após a definição da variedade mais adaptada à área de plantio, é preciso atentar para a utilização de mudas sadias, livres de pragas e doenças. É possível planejar o plantio das próprias mudas ou buscar no mercado um fornecedor idôneo (ROSSETTO; SANTIAGO, 2018).

Diferentes métodos de produção de mudas são adotados pelas unidades produtivas no Brasil. O método convencional consiste no transplantio do colmo-semente da área de cultivo para a área de plantio. Recentemente, com o objetivo de aumentar a produtividade, novas tecnologias e sistemas produtivos vêm sendo desenvolvidos. É o caso dos sistemas de mudas pré-brotadas (MPB), onde mudas livres de patógenos e alta homogeneidade são produzidas em viveiros (SILVA, 2017).

\subsubsection{Sistema convencional para obtenção de mudas de cana-de-açúcar}

No método convencional, colmos de 30 a $50 \mathrm{~cm}$, com 3 a 5 gemas, são retirados das touceiras e depositados diretamente no sulco de plantio, de forma manual ou mecânica. As gemas devem estar livres de patógenos, ter alta capacidade de brotação e ser uma cultivar produtiva. Para garantir essas qualidades devem ser usadas mudas que estejam em crescimento vegetativo, geralmente de 8 a 10 meses (SILVA, 2017).

No plantio manual, o número de colmos consumidos é menor do que no plantio mecanizado, já que é possível posicionar os colmos nos sulcos de forma a ganhar maior uniformidade na lavoura. Com o advento do plantio mecanizado, a quantidade de falhas na plantação aumentou, trazendo prejuízos significativos de produtividade. Portanto, os produtores se viram obrigados a aumentar o número de colmos adicionados aos sulcos. $\mathrm{O}$ volume de mudas necessárias cresceu de 11 a 14t/ha para valores superiores à 20t/ha, gerando um consumo excessivo de colmos que poderiam estar sendo destinados à indústria (LANDELL et al., 2012).

\subsubsection{Sistema de Mudas Pré-brotadas (MPB)}

Com a intenção de identificar métodos para reduzir o volume de mudas adicionadas e aumentar a produtividade, o Instituto Agronômico de Campinas (IAC) lançou o método de produção de Mudas Pré-Brotadas (MPB) (LANDELL et al., 2012). Através deste método, a forma de distribuição espacial das mudas, nas áreas de produção, induz ao melhor aproveitamento dos recursos hídricos e nutricionais, o que reduz a competição intraespecífica estabelecida em canaviais com excesso de mudas, situação bastante comum em áreas 
comerciais de plantio mecanizado. O sistema MPB de cana-de-açúcar consiste no processo de produção de mudas a partir de gemas individualizadas. A tecnologia restaura os benefícios da formação de mudas em viveiros, contribuindo também para reduzir as ocorrências de pragas e doenças na implantação do canavial pelo uso de mudas sadias (LANDELL et al., 2012).

O sistema de mudas pré-brotadas (MPB) leva ao campo mudas oriundas de cortes do colmo, conhecidas como mini rebolos, que possuem em média três centímetros de comprimento, onde estão localizadas as gemas, responsáveis pela brotação. A multiplicação das mudas segue um rigoroso mecanismo de manejo, com atenção redobrada em relação aos cuidados fitossanitários (SILVA, 2017).

O processo para produção de MPB inicia-se com seleção de colmos de qualidade. A técnica possui seis estágios principais i) Corte e preparo do mini rebolo; ii) Tratamento das gemas; iii) Brotação; iv) Individualização ou "repicagem"; v) Aclimatização fase 1 e vi) Aclimatização fase 2. Este conjunto de etapas demora aproximadamente 60 dias (LANDELL et al., 2012).

\subsubsection{Sistema Meiosi para produção de mudas de cana-de-açúcar}

O sistema Meiosi (Método inter-rotacional ocorrendo simultaneamente) destaca-se pela produção da muda da cana-de-açúcar na própria área de renovação, ocasionando redução de custo de implantação na cultura da cana-de-açúcar. Após o preparo do terreno, sulcam-se duas linhas de cana e deixam-se oito sem sulcar, as quais podem ser utilizadas para um cultivo intercala. Após um período de seis a oito meses, as duas linhas de cana serão suficientes para completar as oito linhas remanescentes (ROSSETTO; SANTIAGO, 2018). A vantagem quantitativa e econômica na adoção dessa técnica está relacionada à idade das mudas (seis meses), significando maior vigor, justificando menor consumo de gemas para implantar um hectare, melhor sanidade e maior rendimento de corte. O plantio realizado nesse sistema elimina a necessidade do carregamento e do transporte de mudas, bem como a picação desta, minimizando de carregamento e transporte (PONCIANO et al., 2010). 
Figura 15 - Modelo esquemático do sistema de Meisoi na reforma do canavial.
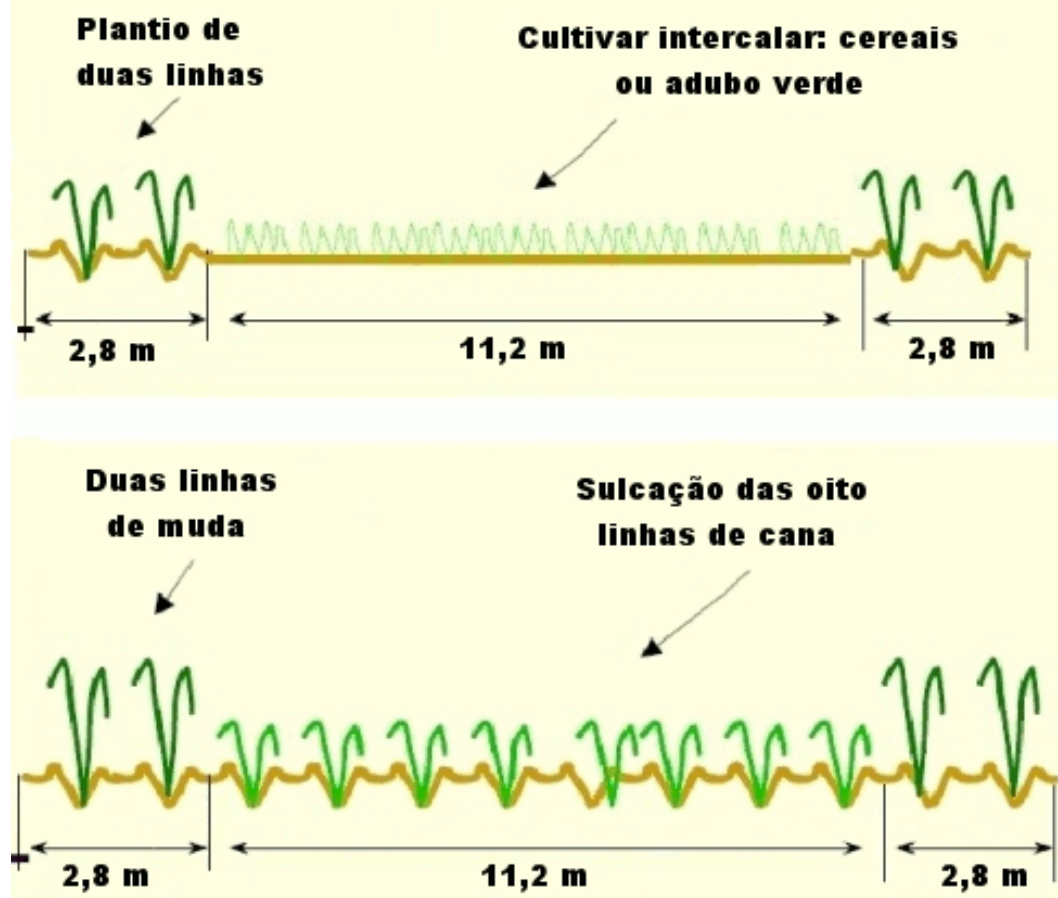

Fonte: Rossetto e Santiago (2018)

O sistema Meiosi pode ser associado à produção de MPB, ou seja, as linhas que constituem a Meiosi são plantadas na forma de MPB, o que tem possibilitado taxas de 1:12 a 1:14 (CHERUBIN, 2016). Estimativas apontam para uma redução nos custos de plantio na ordem de $\mathrm{R} \$ 2500,00$ por hectare devido ao menor uso de mudas, receita na cultura intercalar e maior quantidade de cana entregue à indústria, pois a cana que seria plantada será industrializada, gerando receita ao produtor (RUIZ, 2018).

\subsubsection{Sistema Cantosi para produção de mudas de cana-de-açúcar}

A Cantosi é um sistema que consiste em utilizar viveiros em um canto das áreas que serão renovadas (em torno de $20 \%$ da área) e utilizar as outras $80 \%$ em plantio de grãos ou leguminosas. Isto permite produzir mudas de cana-colmo de qualidade no mesmo local a ser renovado, trazendo também benefícios com a redução do custo de transporte (CHERUBIN, 2016). 


\subsubsection{Conservação e Preparo do Solo}

\subsubsection{Sistematização}

Antes da implantação de um canavial, deve-se fazer o planejamento da área, realizando um levantamento topográfico (ROSSETTO; SANTIAGO, 2009a). O objetivo principal da topografia é efetuar o levantamento, através da execução de medições de ângulos, distâncias e desníveis, que permitam representar uma porção da superfície terrestre em uma escala adequada. Às operações efetuadas em campo, com o objetivo de coletar dados para a posterior representação, denomina-se levantamento topográfico (VEIGA; ZANETTI; FAGGION, 2012).

A sistematização visa, principalmente, a conservação do solo e objetiva um melhor rendimento de logística no processo de colheita mecanizada, como a criação de estradas e carreadores. Executa as delimitações de APP, fragmentos de mata, linhas de transmissão, terraços / curvas de nível e carreadores. Inclui limpeza do terreno, como a retirada de possíveis obstáculos, que possam dificultar as atividades posteriores (INSTITUTO DE ECONOMIA AGRÍCOLA DO ESTADO DE SÃO PAULO (IEA); UNIÃO DOS PRODUTORES DE BIOENERGIA (UDOP), 2016).

Terraços ou curvas de nível têm a finalidade de minimizar o poder erosivo das enxurradas cortando o declive. Permite a contenção das enxurradas, forçando a absorção da água da chuva pelo solo, ou a drenagem lenta e segura do excesso de água. Cada terraço protege a faixa que está logo abaixo dele, ao receber as águas da faixa que está acima. O terraço pode reduzir as perdas de solo até $80 \%$ e de água em até $100 \%$, desde que seja criteriosamente planejado, executado e conservado (IEA; UDOP, 2016).

O levantamento topográfico e a sistematização também são utilizados na agricultura de precisão. A partir de dados específicos de áreas geograficamente referenciadas, implanta-se o processo de automação agrícola (IEA; UDOP, 2016). O piloto automático é uma das tecnologias de agricultura de precisão mais utilizadas. Pode ser acoplada em tratores que direcionam as faixas de preparo de solo, canteirizado, e auxiliam diretamente a operação de plantio fazendo o paralelismo dos sulcos. Também é bastante utilizado em colhedoras para colher somente no sentido da linha e na operação de transbordamento para trafegarem nas entrelinhas e causarem menos pisoteio (CHERUBIN, 2018). 


\subsubsection{Correção do Solo}

Após o término da sistematização do terreno, o produtor deve coletar amostra de solo em cada talhão para análise com vistas às operações de correção do solo e adubação (ROSSETTO; SANTIAGO, 2009a).

O uso de corretivos é fundamental para a melhoria da fertilidade do solo e dos ambientes de produção para a cana-de-açúcar. Considera-se como práticas corretivas o uso do calcário para corrigir a acidez, o uso do gesso para diminuir a atividade do alumínio e acrescentar cálcio em profundidade, e a fosfatagem, que adiciona fósforo em área total para aumentar o teor de fósforo em solos muito pobres desse elemento (IEA; UDOP, 2016).

A torta de filtro, que é um importante resíduo da indústria sucroenergética, proveniente da filtração do caldo extraído das moendas no filtro rotativo, pode ser aplicada em área total, no sulco do plantio ou nas entrelinhas da cana-soca (OS BENEFÍCIOS, 2017) A concentração da torta de filtro é constituída de cerca de 1,2 a 1,8\% de fósforo e cerca de $70 \%$ de umidade, que é importante para garantir a brotação da cana em plantios feitos em épocas de inverno na região Centro-Sul. A torta também apresenta alto teor de cálcio e consideráveis quantidades de micronutrientes. E proporciona melhor desenvolvimento radicular e menores riscos de toxidez da planta por alumínio (OS BENEFÍCIOS, 2017).

A vinhaça, que é rica em nutrientes, sendo o potássio em maior quantidade, pode ser aplicada através da fertirrigação. De maneira geral, esta aplicação busca um ganho maior de produtividade e redução no uso de fertilizantes químicos. $\mathrm{O}$ uso controlado é uma boa prática na cultura da cana do ponto de vista ambiental e produtivo, pois permite a total reciclagem do resíduo industrial, aumentando a fertilidade de solo, redução da captação de água para irrigação, redução do uso de fertilizantes e custos decorrentes. O transporte desse adubo líquido é feito através de caminhões ou canais (IEA; UDOP, 2016).

\subsubsection{Preparo do Solo}

Como a cultura da cana-de-açúcar é altamente mecanizada, prevê-se que mais de 30 operações ocorrem em um mesmo talhão ao longo de cinco anos, o que leva a uma compactação do solo ao longo dos anos do canavial. Durante a reforma do canavial, o preparo do solo tornase uma questão crítica, já que o seu sucesso está relacionado à alta produtividade e longevidade do canavial (SANTIAGO; ROSSETTO, 2009a)

A escolha do sistema de preparo dependerá do adequado diagnóstico dos fatores limitantes ao desenvolvimento radicular. Dependendo das condições de talhão, pode-se optar 
pelo sistema convencional de preparo do solo, pelo cultivo mínimo ou pelo plantio direto (SANTIAGO; ROSSETTO, 2009a)

\subsection{Preparo convencional}

O preparo convencional do solo consiste no revolvimento de camadas superficiais para reduzir a compactação, incorporar corretivos e fertilizantes, aumentar os espaços porosos e, com isso, elevar a permeabilidade e o armazenamento de ar e água. O sistema de preparo convencional utiliza-se normalmente de operações como aração ou gradagens pesadas, subsolagem ou mais uma gradagem, uma gradagem de destorroamento e uma gradagem de nivelamento (SANTIAGO; ROSSETTO, 2009b).

As desvantagens relacionadas ao preparo convencional do solo estão relacionadas às operações agrícolas que promovem o revolvimento da terra elevam muito a oxigenação do solo, aumentando, também, a atividade microbiana, com consequentes perdas de carbono para a atmosfera, contribuindo com o aquecimento global e com a perda de matéria orgânica do solo. Nesse sentido, as técnicas de plantio direto e cultivo mínimo, quando possíveis, são indicadas. (SANTIAGO; ROSSETTO, 2009b).

\subsection{Sistemas Conservacionistas de Preparo do Solo}

O fim da queima da cana-de-açúcar e a colheita mecanizada trouxeram de volta a discussão sobre o uso dos sistemas conservacionistas na ocasião da reforma (SOARES, 2014). Nesse novo sistema de colheita de cana, resíduos remanescentes da colheita permanecem sobre a superfície do solo, formando uma cobertura morta denominada palhada, que melhora a estrutura do solo e é fonte de para a própria cultura da cana-de-açúcar (OLIVEIRA et al., 1999).

A técnica de cultivo mínimo é caracterizada pela diminuição do revolvimento do solo: a soqueira da cana-de-açúcar é eliminada com o uso de herbicida e, em seguida, é feita a sulcação do solo para o novo plantio. Para a cana-de- açúcar, que permanece no mesmo local por vários anos sem que haja movimentação do solo, é praticamente imprescindível que se faça a subsolagem (ROSSETTO; SANTIAGO, 2009b).

O cultivo mínimo normalmente envolve o plantio de uma cultura em rotação nas áreas de reforma do canavial. Após a erradicação da soqueira, em setembro, faz-se o preparo do solo através de uma grade leve. Se necessário, faz-se uma subsolagem e, posteriormente, a sulcação para o plantio da cultura em rotação. São utilizadas as culturas da soja, amendoim, girassol, crotolária, mucuna e outros adubos verdes (ROSSETTO; SANTIAGO, 2009b). 
Dentre os benefícios do emprego da rotação de culturas, pode-se destacar a economia na reforma do canavial, a conservação do solo devido à manutenção de cobertura numa época de alta precipitação pluvial, o controle de plantas daninhas durante o cultivo anual da cana, o combate indireto a pragas que se hospedam em plantas daninhas e o aumento da produtividade da cana-de-açúcar e produção de alimentos (ROSSETTO; SANTIAGO, 2009b).

\subsubsection{Plantio}

O processo de plantio compreende atividades que vão desde o corte das mudas, o carregamento destas para a área de plantio, abertura dos sulcos, adubação, distribuição das mudas e cobrição.

\subsubsection{Corte das Mudas}

O corte de mudas é uma atividade que pode ser realizada de forma manual ou mecanizada. No processo manual é realizada a quebra das mudas, com uso do podão, feita com cautela para não ferir as gemas e, dessa maneira, não dificultar a sua brotação. O corte mecanizado ocorre em conjunto com a atividade de plantio mecanizado. As mudas que alimentam a plantadora devem estar picadas e, por isso, são colhidas mecanicamente com colhedoras (SANTIAGO; ROSSETTO, 2009c).

\subsubsection{Carregamento e Transporte das Mudas}

O carregamento de mudas é uma atividade que utiliza o recurso dos equipamentos carregadeiras, que pode ser própria ou de terceiros, que irão organizar a carga na carroceria do caminhão de forma a facilitar a distribuição manual. O transbordo de mudas é realizado por um implemento acoplado em caminhão, onde é depositada a muda cortada pela colhedora e transportada até a área do plantio (IEA; UDOP, 2016).

\subsubsection{Sulcação}

A operação de sulcação consiste na abertura de sulcos em uma determinada profundidade para a acomodação da muda. Está relacionada com os seguintes aspectos: espaçamento da cultura, profundidade e largura do sulco para o plantio da cana. Os sulcos devem ter profundidade entre 25 e 30 centímetros, medida que não deve ser excedida, a não ser que o preparo do solo tenha sido mais profundo. As novas raízes devem encontrar um solo 
preparado para formar um sistema radicular amplo e eficiente (SANTIAGO; ROSSETTO, 2009c).

Geralmente, os implementos utilizados para a sulcação também são capazes de efetuar a adubação, simultaneamente. Nessa etapa pode-se efetuar, também, a aplicação de defensivos, como, por exemplo, inseticidas (SANTIAGO; ROSSETTO, 2009c).

\subsubsection{Distribuição no sulco e cobrição}

No plantio manual é necessária a utilização de mão-de-obra para a otimização das seguintes atividades: corte dos toletes em pedaços contendo três gemas, colocação e arrumação da posição dos toletes nos sulcos e fiscalização do plantio (SANTIAGO; ROSSETTO, 2009c).

Como as gemas da ponta do colmo têm maior vigor, é comum colocar no sulco colmos distribuídos em "pé com ponta”, ou seja, deve-se sobrepor às últimas duas gemas do pé da cana com outras duas gemas da ponta de um outro colmo(SANTIAGO; ROSSETTO, 2009c).

Logo após o seccionamento dos colmos em pedaços de três gemas, deve-se realizar a cobertura, tendo por objetivo cobrir e colocar a muda em contato com o solo e eliminar bolhas de ar para que se tenha uma melhor germinação. As mudas ficam o menor tempo possível expostas à luz do sol, para não sofrer perda de (IEA; UDOP, 2016; SANTIAGO; ROSSETTO, 2009c)

A Operação de plantio também pode ser realizada por plantadora ou distribuidora, tendo por objetivo distribuir uma quantidade uniforme de gemas viáveis de cana por metro, além dos fertilizantes e defensivos recomendados (IEA; UDOP, 2016).

\subsubsection{Tratos Culturais}

Os tratos culturais são realizados após o plantio e também após todos os cortes subsequentes, sendo o período de estabelecimento do canavial o mais crítico, devido à maior susceptibilidade ao ataque de pragas, doenças e competição com as plantas invasoras (TOWNSEND, 2000).

Os cuidados em tratos culturais, tanto na cana planta, quanto na cana soca, envolvem o controle de invasoras mediante capinas manuais ou mecânicas ou pelo uso de herbicidas. $\mathrm{O}$ monitoramento de pragas (formigas, cigarrinhas e lagartas) e doenças (raquitismo, mosaico e carvão) deve ser constante, adotando-se medidas de controle, quando necessário (TOWNSEND, 2000). 
As seguintes atividades são realizadas durante os tratos culturais: enleiramento da palha (em cana soca), escarificação, adubação do solo e controle fitossanitário. A utilização de maturadores, dependendo da necessidade de antecipar a época da colheita, também pode ser realizada nesta etapa.

\subsubsection{Enleiramento}

Em cana soca, no caso da adoção da colheita mecânica, os restos de palha são deixados sobre o terreno, podendo ou não ser aleirados. Ao ficar sobre o terreno, a palha pode proteger o solo, minimizando a evaporação da água do solo e auxiliando no controle de algumas espécies. Por outro lado, a permanência da palha sobre o solo também pode favorecer o aparecimento de pragas como por exemplo a cigarrinha das raízes, que dependendo dos níveis de infestação, podem provocar severos danos sobre a produtividade. Por esta razão, em algumas regiões a palha vem sendo aleirada (MILLER, 2008b).

\subsubsection{Escarificação}

Tanto em cana planta, quanto em cana soca, tendo em vista a preparação da superfície do terreno para a colheita mecânica, os canaviais são submetidos a operações de escarificação para rebaixar a parte elevada das entrelinhas. Na cana planta, este trabalho deve ser feito por vota dos 45 a 60 dias depois do plantio. Estes tratos culturais são realizados com equipamentos que podem executar simultaneamente aplicação de inseticidas e fertilizantes nas entre linhas (MILLER, 2008b).

\subsubsection{Correção do Solo}

Após o manejo da palha, a aplicação de adubos depende das condições do solo e envolve o fornecimento de fontes de nitrogênio e potássio e fósforo. A vinhaça, que é um resíduo da indústria, também pode ser aplicada nesta fase, já que apresenta grande concentração de nutrientes (como potássio, matéria orgânica, nitrogênio (MILLER, 2008b).

\subsubsection{Controle Fitossanitário dos Canaviais}

Tanto no estágio de cana planta quanto de cana soca, as lavouras de cana-de-açúcar precisam de proteção contra a concorrência de fatores limitadores da produtividade, como plantas daninhas e as pragas. 


\subsection{Controle de Ervas Daninhas}

As plantas daninhas competem com a cana-de-açúcar por água e nutrientes e, as mais agressivas, inclusive por espaço físico. A atividade que tem por objetivo combater as plantas daninhas pode ser realizada através de capinas manuais ou mecânicas, ou também pelo uso de herbicidas (MILLER, 2008b).

Os tipos e momentos de aplicação de um herbicida estão condicionados às características dos produtos e aos estágios de desenvolvimento da planta daninha. Essas duas características conferem à aplicação do produto e ao próprio produto uma classificação importante para as indicações dos procedimentos indicados para o controle do mato, quando se materializa uma recomendação de controle (MILLER, 2008b).

\subsection{Controle de Pragas}

As pragas podem ser combatidas com inseticidas químicos ou biológicos e as doenças, normalmente, não são controladas com produtos aplicados, sendo o manejo varietal ou o arranquio da planta doente, formas amplamente utilizadas (IEA; UDOP, 2016).

O monitoramento de campo efetuado por equipes de colaboradores é essencial para identificação e quantificação de pragas e doenças em canaviais. O Manejo Integrado de Pragas (MIP) é uma estratégia definida pela Organização das Nações Unidas para a Agricultura e Alimentação (FAO) que associa várias ações, como a análise da ocorrência de pragas, identificação e monitoramento constante dos diferentes sintomas na lavoura, inspeção das mudas no plantio e também como controlar pragas.

As ferramentas utilizadas dentro do MIP envolvem o monitoramento da população de insetos, pragas e doenças; o controle biológico de pragas com o intuito de favorecer o aparecimento de inimigos naturais; utilização de controle químico somente quando o ataque à lavoura atinge o nível de dano econômico, ou seja, para um inseto ser chamado de praga é necessário que haja prejuízo para a lavoura (SANTIAGO E ROSSETO, EMBRAPA)

\subsubsection{Uso de Maturadores}

Maturadores são produtos químicos que induzem o amadurecimento de plantas. Essa atividade é realizada para otimizar o planejamento da colheita. O seu objetivo é aumentar o potencial de ATR da cana para antecipar a época da colheita (ROSSETTO, 2009). 


\subsubsection{Colheita, Carregamento e Transporte (CCT)}

A colheita pelo método tradicional ocorre através da queima do canavial para eliminar as folhas secas e verdes consideradas descartáveis previamente ao corte, que ocorre manualmente (TRENTINI; DARIO, 2014). No entanto esse sistema tem sido gradativamente substituído pelo corte mecanizado, em razão da proibição da queima de cana-de-açúcar. No estado de São Paulo, a Lei Estadual no 11.241 proíbe as queimadas a partir de 2021 nas áreas mecanizáveis. a partir de 2018, ele foi totalmente proibido (RONQUIM, 2010).

São três as operações para garantir a entrega da cana na esteira da esteira: Corte, Carregamento e Transporte. Com a determinação do fim das queimadas, o corte começou a ser realizado de forma mecanizada e o carregamento foi substituído pelo transbordo, operação realizada por um implemento tracionado por tratores, cuja função é receber a cana-de-açúcar picada das colhedoras e transbordar para caminhões específicos de cana picada, que realizam o transporte até a usina (TRENTINI; DARIO, 2014).

A etapa do CCT representa a maior parte dos custos envolvidos na produção de cana-deaçúcar e concentra as principais complexidades de manejo da lavoura. Outro aspecto importante relacionado à esta operação é que os investimentos em estrutura são elevados (TRENTINI; DARIO, 2014).

Além do custo e do elevado investimento, a cana-de-açúcar tem uma característica que exige uma logística eficiente entre o campo e a usina. Ela não pode ser estocada ou armazenada porque logo após a sua colheita, a planta passa a sofrer uma série de processos biológicos e químicos que deterioram a sua qualidade, reduzindo a quantidade de açúcares nela contidos e prejudicando o rendimento do processo industrial na fabricação de etanol e açúcar. Após $72 \mathrm{~h}$ ocorrem perdas significativas. Por isto a distância entre o canavial é um fator determinante nos acordos de fornecimento (TRENTINI; DARIO, 2014).

Outro fator colheita da cana-de-açúcar não pode ser realizada em períodos de elevada umidade do solo, pois isso impossibilita as operações de carregamento e transporte da cana-deaçúcar, além de compactar o terreno e reduzir a produtividade da área nos próximos anos (TRENTINI; DARIO, 2014).

Os mesmos autores concluem também que toda esta demanda por investimentos, por uma complexa organização e uso intensivo de tecnologia que só podem proporcionar ganhos com economia de escala. Esse é um dos motivos que induz à terceirização da atividade (TRENTINI; DARIO, 2014). 


\subsection{Processo de Comercialização}

\subsubsection{Contratos de fornecimento de cana-de-açúcar}

Segundo Pedroso Júnior (2008), as usinas podem garantir o suprimento de cana-deaçúcar através de seis tipos de arranjos institucionais de produção de cana, que pode ser produzida em área própria ou através do fornecimento por produtores independentes. A cana própria pode ser produzida em área própria, arrendada ou através da modalidade de parceria. Já a modalidade de suprimento por produtores independentes, pode envolver negociação à vista, o fornecimento sem CCT e o fornecimento com CCT. Segundo Conejero et al. (2008) existe ainda o contrato com o fornecedor em que o proprietário deixa a terra pronta e faz os tratos culturais, e a usina faz plantio e colheita.

A estratégia de produção da cana própria apresenta vantagens e desvantagens para as usinas. As vantagens estão relacionadas ao controle integral do suprimento de cana, a um planejamento da produção com maior flexibilidade nas decisões (escolha das variedades, época de colheita, otimização da usina e do transporte), à redução de custos administrativos e operacionais e a questões de equilíbrio fiscal entre a usina e à produção, pelos preços de transferência. Quando a usina produz em área própria, as desvantagens estão relacionadas à elevada imobilização de ativos, rentabilidade questionável, dependendo do custo do hectare da região, elevado custo administrativo e operacional e riscos fitossanitários e climáticos, invasões de área etc. Quando a usina produz em área arrendada, ela não necessita imobilizar em terras, porém tem o risco de rompimento de contrato, oscilações de mercado e risco da concorrência de outras culturas e vulnerabilidade na renegociação de contratos (CONEJERO et al., 2008).

Aliado a outros fatores, como o custo elevado da terra e a presença de concorrência de outras usinas, a presença de fornecedores capacitados via criação de uma associação, ou que possam compartilhar gestão das propriedades e ativos pode fazer com que as usinas prefiram terceirizar a produção, entre outros (CONEJERO et al., 2008).

A negociação à vista envolve aqueles fornecedores que cultivam a lavoura e negociam a sua produção com as usinas existentes no decorrer de cada safra canavieira. Esta modalidade também é conhecida no setor sucroenergético como “compra spot de cana”. Para os produtores, esse mercado spot somente se mostra viável em regiões onde existe demanda garantida, pois, do contrário, o produtor corre o risco de não conseguir vender a cana que cultivou. Por outro lado, para as usinas, este tipo de transação é arriscado, no sentido de ficar sem produção e trazer dificuldades de produção (TRENTINI; DARIO, 2014). 
Nesse contexto, a função do contrato de fornecimento entre produtores e usinas é garantir uma estabilidade em determinados aspectos da relação negocial, poupando as partes de renegociações periódicas. Desta forma, o fornecedor se obriga, durante o prazo ajustado, a cultivar a cana segundo na quantidade acordada e nos padrões de qualidade estabelecidos (prestação periódica, sucessiva e descontínua) e, de outro lado, o empresário da indústria sucroenergética se compromete a adquirir essa matéria-prima e pagar o preço (TRENTINI; DARIO, 2014)

Segundo Conejero et al. (2008), na região Centro-Sul do país, estima-se que hoje a maior parte das áreas cultivadas com cana pertencem às usinas (propriedade e arrendamento). No entanto, dada a baixa rentabilidade do ativo terra, esta tendência vem se invertendo. As usinas de açúcar e álcool do Centro-sul estão buscando aumentar a base de fornecedores integrados ao seu subsistema.

Dentre os novos modelos de governança, o contrato de fornecimento mais utilizado é o de "fornecimento com CCT". As atividades de corte, carregamento e transporte da matériaprima ficam a cargo da usina, que desconta o custo do serviço do preço da matéria prima. No contrato de "fornecimento sem CCT", o produtor realiza esta atividade. As alterações na legislação ambiental, realizadas desde a década de 1990, assim com a incorporação de novas obrigações na legislação trabalhista colaboraram para a escolha do modelo contratual "fornecimento com CCT", principalmente por pequenos e médios produtores, que, em decorrência dos custos para implementar as mudanças, precisam contar com a usina para a realização de suas atividades (TRENTINI; DARIO, 2014).

Um ponto importante destacado por Trentini e Dario (2014) é que, ao terceirizar a operação de CCT, há uma perda significativa de independência dos produtores em relação à indústria, que perde o poder de decisão sobre a colheita, com reflexos na produtividade e no resultado econômico. Além disso também reduz seu poder de barganha na negociação e renovação dos contratos. Os autores alertam para a necessidade de organização dos produtores através de associações ou cooperativas para reduzir esta dependência.

\subsubsection{Sistema CONSECANA}

O modelo de precificação da maioria dos contratos de fornecimento de cana-de-açúcar da região centro-sul do Brasil é regido pelo CONSECANA-SP - Conselho dos Produtores de Cana-de-Açúcar, de Açúcar e de Etanol do Estado de São Paulo, que foi criado em 1999 com a desregulamentação do setor. O CONSECANA foi constituído com representação paritária de 
representantes de fornecedores e indústrias e tem como principal objetivo zelar pelo relacionamento entre essas partes (FARINA; GIANNETTI, 2014).

Com este intuito, o órgão criou um conjunto de regras para viabilizar um método de precificação da matéria-prima. O modelo propõe a valorização da cana entregue à usina pela quantidade de Açúcar Total Reversível (ATR) contido. O valor da ATR será vinculado aos preços médios dos produtos acabados (açúcar e álcool), à participação do custo da matériaprima (cana) no custo do açúcar e do álcool e no Mix de produção do ano-safra de cada unidade industrial (CONEJERO et al., 2008).

Com a necessidade operacional de moagem das usinas de recebimento linear de cana ao longo da safra, os sistema também contribuiu com o ATR Relativo, que foi a forma encontrada para tornar indiferente à data de entrega pelo fornecedor e ainda incentivar a busca por performance (FARINA; GIANNETTI, 2014) .

No entanto, apesar de o sistema CONSECANA ser uma referência de modelo de relacionamento e autogestão no agronegócio, as regras utilizadas para uniformizar a precificação da cana entre produtores e usinas não foram atualizadas no mesmo ritmo das mudanças decorridas desde a sua implantação em 1999. Apesar do grande salto dos custos agrícolas nos últimos anos, relacionados à mecanização e consequentes mudanças dos sistemas de manejos e controles de novas pragas, não foi feita a adequação da parcela do custo de produção da cana-de-açúcar na fórmula do preço do ATR. Além disso, as novas exigências do mercado, que demandam dos produtores esforços orientados para a melhoria contínua da qualidade da cana, também não estão sendo reconhecidas no modelo atual de precificação ${ }^{10}$.

Tendo em vista todos estes problemas, o conselho vinha trabalhando em uma remodelagem do modelo. Em 25 de março de 2019, foi aprovado o termo de atualização do modelo CONSECANA-SP ${ }^{11}$, que determina novos parâmetros técnicos e diretrizes relacionadas ao pagamento de cana entregue pelos produtores às unidades industria. As atualizações contempladas no modelo incluem:

I. Prêmio associado à qualidade da matéria prima, atrelado à instituição de um parâmetro técnico e uma sistemática de apuração padronizada.

II. Compartilhamento de valor por meio do reconhecimento de indutores de maior eficiência, que envolvem fidelidade contratual, adequação a normas regulamentadoras, remuneração para cana certificada e cumprimento da programação da safra.

\footnotetext{
${ }^{10}$ Informações fornecidas pela Gestão Executiva da Orplana.

${ }^{11}$ Nota divulgada às entidades associadas à Orplana (informação fornecida pela Gestão Executiva da Orplana).
} 
III. Incorporação ao sistema CONSECANA-SP dos preceitos da política nacional de biocombustíveis (RenovaBio) - LEI Nº 13.576/17.

\subsection{Processos de Gestão do Negócio}

\subsubsection{Planejamento e Gestão de Resultados}

Para a otimização dos resultados das unidades produtivas, segundo Beauclair (2004), é preciso uma visão estratégica, em um horizonte de cinco a dez anos, projetando cenários para uma tomada de decisão mais eficaz.

Nenhuma política de produção pode ser realizada sem um planejamento estratégico, e a elaboração deste planejamento deve envolver os diferentes setores da empresa. Sendo assim, ele deve integrar as áreas agrícola, industrial, comercial e financeira, além de considerar a base física e a financeira (BEAUCLAIR, 2004).

A implantação do canavial, seja em uma área nova ou de reforma, demanda um elevado investimento. Instrumentos de análise econômica, através de estimativas de investimento na reforma e projeções de fluxo de caixa, podem proporcionar meios de tomada de decisão racional sobre o melhor momento para renovar o canavial e sobre investimentos em infraestrutura e adoção de novas tecnologias (VEIGA FILHO, 2002).

O planejamento considera a disponibilidade de fatores de produção (terra, máquinas e equipamentos, insumos, mão de obra, capital e tecnologia) e uma projeção da evolução dos custos e da rentabilidade decorrentes do ciclo da cultura, supondo uma condição no seu manejo e condições externas. Instrumentos de análise econômica, através de estimativas de investimento na reforma e projeções de fluxo de caixa, podem proporcionar meios de tomada de decisão racional sobre o melhor momento para renovar o canavial e sobre investimentos em infraestrutura e adoção de novas tecnologias. Estas projeções são realizadas com base nas estimativas de produtividade e custos para cada corte (VEIGA FILHO, 2002).

O planejamento agrícola é fundamental para estimar a produtividade em cada estágio de corte, dentro de cada ambiente de produção, assim como sua evolução ao longo dos anos. Para projeções das áreas da lavoura, visando à quantificação da produção ao longo de um horizonte de cinco a dez anos, planilhas eletrônicas de simulação de produção e modelos de otimização são utilizados e dependem das estimativas de produção de cada variedade, ao longo de seu ciclo (BEAUCLAIR, 2004).

Estas projeções são realizadas com base nas estimativas de produtividade e custos para cada corte. Planilhas eletrônicas de simulação de produção e modelos de otimização podem ser 
utilizados e dependem das estimativas de produção de cada variedade, ao longo de seu ciclo (BEAUCLAIR, 2004).

Estas estimativas são decorrentes de um conhecimento cada vez mais aprimorado sobre o processo produtivo e da utilização de ferramentas e recursos que auxiliem o produtor nas tomadas de decisão relacionadas à escolha das variedades que irão se adaptar melhor, determinação da época do plantio e da colheita e das técnicas de manejo.

No universo das commodities, onde se encaixa a cana-de-açúcar, os gestores não têm como propriamente fazer a gestão sobre o preço de venda. Portanto, o foco da gestão é principalmente pautado nos custos. O custeio por atividades permite a visualização dos impactos financeiros em cada etapa do processo e o gerenciamento dos recursos segundo a relação custo-benefício de cada atividade. O benchmarking é uma ferramenta que pode nortear o andamento do negócio, auxiliando na formação das perguntas e/ou conclusões de onde estão os pontos a serem atacados para a busca de melhores resultados (IEA; UDOP, 2016).

\subsubsection{Adequação à Legislação}

Diversas foram as alterações na legislação desde o final da década de 1990. Na legislação ambiental é possível destacar a proibição da queima de cana-de-açúcar em um cronograma progressivo. A legislação trabalhista também incorporou obrigações para garantir maior bemestar aos trabalhadores no campo (FARINA; GIANNETTI, 2014).

\subsubsection{Adequação à Legislação Trabalhista}

As relações de trabalho rural são previstas pela Lei 5.889/73, regulamentada pelo Decreto $\mathrm{n}^{\mathrm{o}} 73.626 / 74$, que equiparou o trabalho rural ao urbano, ampliando, assim, os direitos deste empregado (AS DIFERENÇAS, 2017).

As Normas Regulamentadoras, conhecidas pela sigla NR são um conjunto de exigências ligadas à área de saúde e segurança do trabalho que empresas privadas ou públicas devem seguir quando possuem empregados regidos pela CLT (Consolidação das Leis do Trabalho). Dentre as obrigações previstas pela NRs, em especial a 1, 6, 7, 9, 12 e 31, estão a realização de exames médicos, presença de material necessário à prestação de primeiros socorros, garantia de remoção gratuita do empregado em caso de acidentes, pausas para descanso, ferramentas adequadas para trabalho, fornecimento de equipamentos de proteção individual (EPIs), instalações sanitárias e para alimentação adequadas, água potável e veículos para transporte coletivo seguro e regulamentado (COSTA, 2018). 


\subsubsection{Adequação à Legislação Ambiental}

A Lei 12.651, de 25 de maio de 2012, também conhecida como Novo Código Florestal, estabelece normas gerais sobre a proteção da vegetação nativa, incluindo áreas de preservação permanente, de reserva legal e de uso restrito, a exploração florestal, o suprimento de matériaprima florestal, o controle da origem dos produtos florestais, o controle e prevenção dos incêndios florestais e a previsão de instrumentos econômicos e financeiros para o alcance de seus objetivos (ENTENDA A LEI, 2019).

O Cadastro Ambiental Rural (CAR) e a previsão de implantação do Programa de Regularização Ambiental (PRA) são programas contemplados no novo Código Florestal (ENTENDA A LEI, 2019).

Com o CAR, será possível ao Governo Federal e aos órgãos ambientais estaduais conhecerem a localização de cada imóvel rural e a situação de sua adequação ambiental. Tratase de um diagnóstico ambiental a partir de um levantamento de informações georreferenciadas do imóvel, com delimitação das Áreas de Proteção Permanente, Reserva Legal, remanescentes de vegetação nativa, área rural consolidada, áreas de interesse social e de utilidade pública (BRASIL, 2019; ENTENDA A LEI, 2019).

O PRA permitirá que os estados orientem e acompanhem os produtores rurais na elaboração e implementação das ações necessárias para a recomposição nas Áreas de Preservação Permanente, de Reserva Legal ou de Uso Restrito (ENTENDA A LEI, 2019). O Programa foi regulamentado no âmbito do Estado de São Paulo em 2016. Para participar, o proprietário ou possuidor de imóvel rural deve requerer a inclusão de um Projeto de Recomposição de Áreas Degradadas e Alteradas (PRADA). Através deste projeto, ele irá demonstrar o que vai fazer para adequar seu imóvel ao Código Florestal, incluindo o detalhamento sobre como será feita a restauração das áreas degradadas (SÃO PAULO, 2019)

O produtor de cana-de-açúcar também precisa adequar-se à Lei Estadual nº 11.241 que, a partir de 2002, estipulou a eliminação gradativa da queima nos canaviais com prazo final em 2021 para áreas mecanizáveis e em 2031 para áreas não mecanizáveis (RONQUIM, 2010). No entanto, em 2007, foi assinado o Protocolo Agroambiental que antecipa estes prazos. O protocolo foi assinado pelo Governador de São Paulo, pelos Secretários de Estado do Meio Ambiente e de Agricultura e Abastecimento e pelos presidentes da União da Indústria de Canade-Açúcar (Unica) e da Organização de Plantadores de Cana da Região Centro-Sul do Brasil (Orplana) com a intenção de desenvolver ações que estimulem a sustentabilidade da cadeia produtiva de açúcar, etanol e bioenergia e eliminar as queimadas até 2014, nas áreas 
mecanizáveis e 2017, nas áreas não mecanizáveis para os signatários do Protocolo Agroambiental (SÃO PAULO, 2019).

Entre os impactos das queimadas estão a emissão de uma fuligem ultrafina que expõe milhões de pessoas a esse tipo de poluição atmosférica todos os anos durante os meses da safra. Estudos realizados no Brasil e no exterior têm comprovado uma estreita ligação entre esse tipo de poluição e doenças respiratórias na população exposta à fuligem gerada nas queimadas. As queimadas de cana também emitem para atmosfera uma grande quantidade de gases, entre eles o CO (monóxido de carbono), o CH4 (metano) e o NO2 (óxido nitroso), que contribuem para o aumento do aquecimento global. Outro impacto ambiental causado pelas queimadas é a redução da biodiversidade animal por meio da perda de habitat ou morte, além da vegetal em áreas adjacentes às dos canaviais queimados (RONQUIM, 2010).

\subsubsection{Certificações Socioambientais}

A certificação socioambiental é um instrumento que diversos setores econômicos têm utilizado para demonstrar seu compromisso com a sustentabilidade socioambiental.

No setor sucroenergético, os produtos com certificação podem se diferenciar comercialmente, obtendo preços adequados junto aos consumidores mais exigentes. As indústrias alimentícias e de etanol são as principais responsáveis pelo envolvimento de usinas de cana-de-açúcar nos processos de certificação socioambiental (SILVA, 2010).

Há uma tendência da indústria de reduzir a imobilização de capital em compra de terras. Assim a responsabilidade pela produção vem sendo transferida para produtores independentes através de contratos de fornecimento (CONEJERO et al., 2008; SILVA, 2010). Para garantir a qualidade da matéria prima e a adequação socioambiental exigidas pelo mercado, sistemas de certificação da produção de cana-de-açúcar estão sendo desenvolvidos (SILVA, 2010).

Os princípios de avaliação para certificação da cana-de-açúcar envolvem critérios sociais, relacionados aos direitos dos trabalhadores e respeito às comunidades locais, critérios ambientais, que estão relacionados à preservação do meio ambiente, além de critérios relacionados às boas práticas de produção (SILVA, 2010).

Os principais sistemas de certificação da produção de cana-de-açúcar, atualmente aplicados no Brasil, são: Better Sugarcane Initiative (BONSUCRO), International Sustainableand Carbon Certification System (ISCC), SEKAB e o Roundtable on Sustainable Biofuels (RSB). Estes sistemas não permitem que os produtores isolados ou em grupos consigam se certificar de forma independente. Desta forma, as usinas precisam integrar os produtores a programas desenvolvidos para obtenção de certificação (SILVA, 2010). 


\subsubsection{Governança e Sucessão}

Segundo o Censo Agropecuário realizado pelo o Instituto Brasileiro de Geografia e Estatística - IBGE (2017), o número de estabelecimentos agropecuários no Brasil é de 5,07 milhões, dentre estes aproximadamente $72 \%$ são propriedades rurais familiares. No estado de São Paulo este valor sobe para 77\% (INSTITUTO BRASILEIRO DE GEOGRAFIA E ESTATÍSTICA (IBGE), 2017).

A empresa familiar possui algumas características próprias. A primeira é que o controle da empresa está nas mãos da família, que define os objetivos, diretrizes e políticas. A segunda característica é que a transferência do poder decisório de maneira hereditária, ou seja, a próxima geração assume os lugares deixados por seus parentes e assim sucessivamente (LEONEL, 2012).

Segundo Oliveira ${ }^{12}$ (2010, p. 4, 8 apud LEONEL, 2012) "no Brasil a vida média das empresas não familiares no Brasil é de doze anos e a das empresas familiares é de nove anos, somente $30 \%$ das empresas familiares passam para o comando da segunda geração e apenas $5 \%$ passam para a terceira.

No agronegócio o processo de sucessão se torna ainda mais complexo, uma vez que, além de toda a preparação para gerir um patrimônio, há necessidade de uma aptidão e até um elo afetivo para trabalhar com a terra. Esta aptidão pode ser nata ou adquirida com muita dedicação. Muitas vezes estes valores não são passados de geração para geração. É muito comum, em propriedades rurais, os filhos dos donos buscarem outras atividades profissionais na cidade, principalmente as filhas mulheres (LEONEL, 2012).

Outro fator que pode ameaçar a sobrevivência da empresa familiar é a ineficácia de gestão e profissionalização dos integrantes. O conflito entre afetividade familiar e interesses do negócio normalmente interfere na tomada de decisão. (LEONEL, 2012). A falta de profissionalização da empresa familiar traz alguns impactos negativos na gestão do negócio como, por exemplo, a ausência de estratégias claramente definidas, confusão entre propriedade e gestão, lutas constantes pelo poder, predominância de caprichos individuais, além de eventual falta de clareza quanto à vocação da empresa (STEINBERG \& BLUMENTHAL ${ }^{13}, 2011$, p. 75 adpud LEONEL, 2012).

\footnotetext{
${ }^{12}$ OLIVEIRA, D. de P. R. de. Empresa familiar: como fortalecer o empreendimento e otimizar o processo sucessório. 3. Ed. Editora Atlas São Paulo-SP, 2010.

${ }^{13}$ STEINBERG, H. \& BLUMENTHAL, J. A família empresária: Organizando as relações de afeto, poder e dinheiro por meio de governança corporativa. São Paulo-SP: Editora Gente, 2011.
} 
A governança corporativa é uma estratégia eficaz, que contribui para profissionalização e perpetuação da empresa, através da criação de conselhos, que resulta em maior organização e administração do negócio. (MOREIRA JUNIOR ${ }^{14}, 2006$ apud LEONEL, 2012).

A condução eficaz da sucessão nas empresas é um dos fatores críticos para o sucesso e sobrevivência ao longo das gerações. A definição de um processo sucessório permite que em vida seja definido a forma de como o patrimônio familiar e o controle dos negócios serão transferidos aos sucessores.

Para viabilizar este processo é necessária a formação de uma estrutura societária. Uma solução seria a criação de uma micro ou pequena empresa rural, ou ainda de uma holding (LEONEL, 2012). Outra ferramenta bastante interessante na hora de resolver problemas à governança é a constituição de condomínios que envolve a associação de produtores com o objetivo de produzir, comprar ou vender ou prestar serviço em conjunto em conjunto. Um dos benefícios deste modelo é que permite que seja criada uma estrutura formal, com regras que agradem a todos os interessados (GUERRA, 2018).

\subsubsection{Atuação integrada entre os produtores}

A atuação integrada entre produtores envolve ações coletivas para otimizar estrutura e elevar níveis de gestão, compartilhamento de boas práticas e informações, promovendo maior parceria entre os agricultores. Estas ações colaborativas podem ocorrer através de associações, cooperativas ou através de outras formas de organização, como condomínios e consórcios rurais, por exemplo, ou ainda através de modalidades mais modernas, que é o caso da economia colaborativa, onde bens e serviços podem ser compartilhados através de plataformas digitais.

\subsubsection{Atuação através de Associações e Cooperativas Agrícolas}

Segundo o Ministério da Agricultura, a organização dos produtores através de associações possibilita um meio de pequenos proprietários participarem do mercado em melhores condições de concorrência, viabilizando economicamente as atividades (BRASI, 2016).

\footnotetext{
${ }^{14}$ MOREIRA JUNIOR, A. L. Estratégias de governança na empresa familiar: modelo para redução de conflitos familiares e perpetuação da empresa. Tese (Doutorado em Administração). Universidade de São Paulo. São Paulo-SP, 2006.
} 
O associativismo se constitui em alternativa necessária de viabilização das atividades
econômicas, possibilitando aos trabalhadores e pequenos proprietários um caminho
efetivo para participar do mercado em melhores condições de concorrência. Com a
cooperação formal entre sócios afins, a produção e comercialização de bens e serviços
podem ser muito mais rentáveis, tendo-se em vista que a meta é construir uma
estrutura coletiva das quais todos são beneficiários.

A diferença entre associações e cooperativas é que associações são organizações sem fins lucrativos que promovem a assistência social, educacional, cultural, defesa de interesses de um grupo, enquanto que cooperativas são organizações com viés econômico, possibilitam o negócio dos cooperados no mercado (COOPERATIVISMO, 2016).

A organização dos produtores de cana-de-açúcar através de associações é bastante intensa no Brasil. Na região centro-sul do Brasil, a partir da desregulamentação do setor, a Orplana, associação que representa os interesses dos fornecedores paulistas de cana, começou a elevar o seu poder de aglutinação. Quando o Estado deixou de definir regras que conduziam as relações de poder, o que ocorreu foi uma intensificação da articulação entre os industriais e os fornecedores de cana, o que é evidenciado quando a Unica e a Orplana criam o CONSECANA em 1998 (MELLO; PAULILLO, 2005).

A Orplana é formada por 32 associações, abrangendo 522 municípios canavieiros. Dentro deste conjunto, segundo Castro, Neves e Scare (2015), no período pósdesregulamentação, algumas têm se desenvolvido e outras têm se enfraquecido. Com o intuito de identificar o desenvolvimento das funções institucionais ou técnicas das associações estes autores realizaram uma pesquisa com 22 associações de produtores de cana-de-açúcar nos estados de São Paulo e Minas Gerais. Os benefícios aos associados foram classificados dentro dos temas de Serviços, Comunicação e Representação Política. Um grupo de 10 associações têm nível de atividades praticamente duas vezes maior que as demais. Segundo os autores, existe um desnível significativo de eficiência de representação entre as associações estudas. A lista de serviços mais frequentes identificados na pesquisa e o percentual das associações que oferecem estes serviços é apresentada no gráfico 1: 
Figura 16 - Serviços mais oferecidos pelas associações e percentual de associações que os oferecem
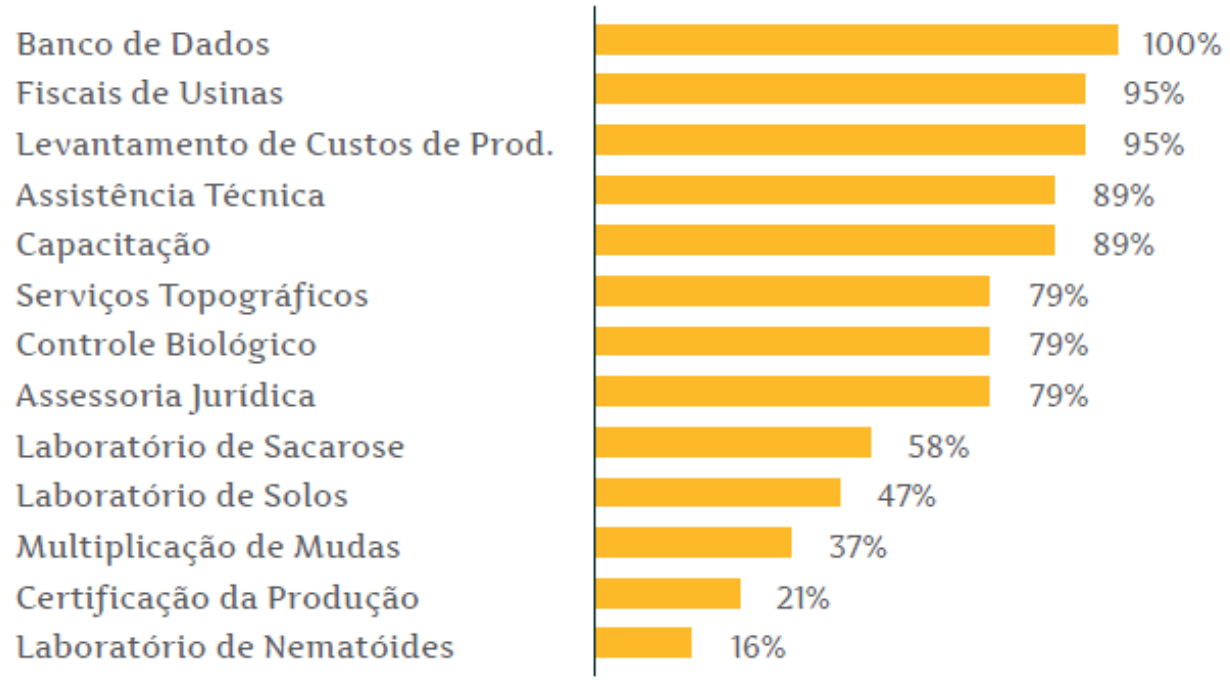

Fonte: Castro, Neves, Scare (2015)

Os produtores de cana-de-açúcar também se organizam através de cooperativas, que atuam oferecendo aos seus cooperados condições de compra de insumos mais acessíveis, incluindo a obtenção de financiamentos, assistência técnica para tomada de decisão agrícola e comercialização dos produtos provenientes das culturas de rotação etc. Algumas associações e cooperativas têm trabalhado em conjunto. O estudo de Castro, Neves, Scare (2015) demonstra que este modelo tem fortalecido as associações. O grupo mais eficiente na prestação de serviços trabalha em paralelo com as cooperativas, que complementam seu trabalho ao realizar atividades de comercialização de produtos, além de outros serviços.

\subsubsection{Realização de operações em conjunto}

Através da união das propriedades, maquinários e mão de obra, alguns grupos de produtores visam produzir em grande escala, reduzir custos, aumentar o seu poder de negociação e, consequentemente aumentar o lucro.

Condomínios e consórcios agrícolas são modalidades societárias que facilitam a união entre os produtores rurais, visando o cumprimento da função social da propriedade rural e a democratização do capital (produção, renda e desenvolvimento econômico vinculado ao setor (VALERIO, 2019).

Segundo a Revista Canavieiros, ao adotar esta modalidade, grupos de produtores podem obter as seguintes vantagens: elevação do nível de profissionalização da atividade, diminuição 
dos casos de informalidade, proteção do patrimônio dos riscos da operação (sucessão, ambiental, trabalhista, tributário e financeiro), além de permitir alto controle dos processos de negócio, mitigando riscos e vulnerabilidade e garantindo a continuidade do negócio (GUERRA, 2018).

Alguns produtores de cana já começaram a se organizar em condomínios e consórcios para compartilhar mão de obra e equipamentos. A reportagem da Revista Coplana (2011) traz um exemplo de produtores de cana, na sua maioria pequenos e médios, localizados geograficamente próximos, que se uniram com dois principais objetivos, reduzir custos com a contratação de prestadores de serviço, compartilhando mão de obra e a estrutura, motivados principalmente pela necessidade de realizar a colheita mecânica, que seria obrigatória a partir de 2017, com o fim das queimadas. Segundo o produtor entrevistado, alguns dos benefícios desta modalidade são: As pessoas contratadas por este condomínio trabalham nas áreas de todos os participantes, reduzindo também o custo com encargos Outro fator relevante citado pelo produtor entrevistado é que os produtores conseguem colher a sua própria cana e levar até a usina, mantendo uma entrega linear de cana e uma cota diária e os custos da realização desta atividade são inferiores à terceirização do serviço (CONSÓRCIOS, 2011).

Existem ainda outras formas de os produtores se agruparem para realizar as operações de forma conjunta e ganhar competitividade. A Revista Canavieiros (GUERRA, 2018) mostra outro caso de fornecedores que fizeram uso da Associação como ferramenta para se organizarem e conseguirem estabelecer uma parceria envolvendo as unidades industriais e gerando previsibilidade e organização na entrega. O grupo industrial, para o qual os 67 associados entregam a cana, estabeleceu um sistema de premiação envolvendo diversos fatores de eficiência, como linearidade de entrega (dentro das cotas diárias), assertividade, qualidade etc. A Associação assumiu a responsabilidade de desenvolver uma estrutura interconectada de acompanhamento e gestão dos processos no campo, garantindo a entrega dentro dos parâmetros demandados pelas usinas.

\subsubsection{Economia de Compartilhamento}

A economia colaborativa ou de compartilhamento é um movimento que vem consolidando a forma como as pessoas vão fazer negócio no futuro. É uma mudança comportamental que representa o entendimento de que a divisão deve necessariamente substituir o acúmulo, ou seja, o acesso aos serviços passa a substituir a busca pela posse dos bens (GONSALEZ, [s.d.]; GUERRA, 2018). 
Os casos mais conhecidos de economia colaborativa são o Uber e o Airbnb. No entanto, são inúmeros os casos em que empresas, através de aplicativos, conectam pessoas a serviços ou produtos.

Nem todo fazendeiro consegue ter os equipamentos disponíveis para sua necessidade, já que o maquinário é caro e passa parte do ano ocioso, após a colheita, por exemplo. Já existem aplicativos disponíveis voltados para o agronegócio que conectam produtores. Um produtor que tem equipamento ocioso e deseja alugá-lo pode cadastrá-lo em determinada plataforma e o produtor que não possui o maquinário entra no aplicativo e encontra a máquina que deseja por meio de geolocalização (COM ALUGUEL, 2017; GRIOSOTTO, 2017). 


\section{LEVANTAMENTO DAS PERCEPÇÕES DOS PRODUTORES DE CANA}

Os dados coletados nas entrevistas foram analisados de forma a identificar percepções positivas e negativas ao longo dos processos mapeados, assim como os agentes do setor envolvidos.

\subsection{Características dos entrevistados}

O Quadro 1 resume as principais características dos entrevistados. Para facilitar a diferenciação dos perfis ao longo das análises subsequentes, optou-se por denominá-los a partir da combinação de duas características: grau de verticalização e porte.

Segundo a classificação adotada pela Orplana ${ }^{15}$, os três primeiros produtores se enquadram na categoria de Grande Porte ( $\geq 1.300$ ha) e os outros dois, na categoria de Pequeno Porte ( $\leq 162$ ha).

Quanto ao grau de verticalização, o critério de segmentação também foi o mesmo utilizado pela Orplana ${ }^{16}$. O produtor 1 tem o domínio quase completo das operações, sendo o transporte a única atividade realizada pela usina. Desta forma, foi classificado como produtor Integral $^{17}$. Os produtores 2, 3 e 4 terceirizam apenas o CCT para as usinas. Além do CCT, o produtor 4, que realiza o corte mecanizado de mudas, contrata o serviço de um vizinho para realizar esta atividade. Estes três, portanto, se enquadram na categoria de produtores Intermediários. O quinto produtor, que tem estrutura para realizar apenas os tratos culturais foi classificado como produtor Básico.

Além do porte e do grau de verticalização, outras características, como produtividade, tipos de usinas para às quais eles fornecem e aspectos sobre os seus processos produtivos, foram resumidos no Quadro 1.

\footnotetext{
${ }^{15}$ Conforme Sessão 4, Figura 9

${ }^{16}$ Conforme Sessão 4, Figura 11

17 O produtor tem suas propriedades distribuídas em dois polos produtivos. No Polo 1, ele terceiriza o CCT e no Polo 2, ele tem estrutura para realizar a colheita e o carregamento. Neste estudo, optou-se por focar a análise no polo produtivo 2 , onde ele adota um perfil de produtor integral.
} 
Quadro 1 - Principais características dos produtores entrevistados

\begin{tabular}{|c|c|c|c|c|c|}
\hline & Produtor 1 & Produtor 2 & Produtor 3 & Produtor 4 & Produtor 5 \\
\hline $\begin{array}{c}\text { Grau de } \\
\text { Controle/Porte }\end{array}$ & Integral / Grande & $\begin{array}{l}\text { Intermediário/ } \\
\text { Grande }\end{array}$ & Intermediário/ Grande & $\begin{array}{c}\text { Intermediário / } \\
\text { Pequeno }\end{array}$ & Básico / Pequeno \\
\hline Área (há) & $\begin{array}{l}>5000 \text { ha } \\
\text { distribuídas em } 2 \text { polos }\end{array}$ & $\begin{array}{c}>4000 \leq 2000 \text { ha } \\
\text { concentradas em uma } \\
\text { região }\end{array}$ & $\begin{array}{l}>2000 \leq 1000 \text { há } \\
\text { distribuídas em } 4 \\
\text { regiões }\end{array}$ & $\begin{array}{c}>78 \leq 162 \text { há } \\
\text { concentradas em um } \\
\text { local }\end{array}$ & $\begin{array}{c}\leq 78 \text { há concentradas em } \\
\text { um local }\end{array}$ \\
\hline Usinas & $\begin{array}{l}1 \text { grupo nacional } \\
2 \text { multinacionais }\end{array}$ & 1 grupo nacional & 2 grupos nacionais & 1 grupo nacional & 1 usina nacional \\
\hline Associações & $\begin{array}{c}\text { Socicana (Polo 1) } \\
\text { Associação 2 (Polo 2) } \\
\end{array}$ & Socicana & $\begin{array}{l}\text { Socicana (Propriedade } \\
\text { de Jaboticabal) }\end{array}$ & Socicana & Socicana \\
\hline \multirow{3}{*}{$\begin{array}{l}\text { Processo } \\
\text { Produtivo }\end{array}$} & $\begin{array}{c}\text { Produção de Mudas } \\
\text { Convencional } \\
\text { Cantosi }\end{array}$ & $\begin{array}{c}\text { Produção de Mudas } \\
\text { Pré-Brotada (MPB) } \\
\text { Meiosi }\end{array}$ & $\begin{array}{c}\text { Produção de Mudas Pré- } \\
\text { Brotada (MPB) } \\
\text { Meiosi }\end{array}$ & $\begin{array}{l}\text { Produção de Mudas } \\
\text { Convencional } \\
\text { Cantosi }\end{array}$ & $\begin{array}{l}\text { Produção de Mudas } \\
\text { Convencional }\end{array}$ \\
\hline & $\begin{array}{l}\text { Rotação com Soja ou } \\
\text { Amendoim }\end{array}$ & $\begin{array}{l}\text { Rotação com Soja ou } \\
\text { Amendoim }\end{array}$ & $\begin{array}{c}\text { Rotação prolongada } \\
\text { Milho-Soja- Amendoim }\end{array}$ & $\begin{array}{l}\text { Rotação com } \\
\text { Amendoim }\end{array}$ & $\begin{array}{l}\text { Rotação com } \\
\text { Amendoim }\end{array}$ \\
\hline & $\begin{array}{c}\text { Plantio Mecanizado } \\
\text { Transporte Terceirizado. } \\
\text { (Polo 2) }\end{array}$ & $\begin{array}{l}\text { Plantio Manual } \\
\text { CCT terceirizado }\end{array}$ & $\begin{array}{c}\text { Plantio Manual } \\
\text { CCT terceirizado } \\
(\text { Jaboticabal })^{19}\end{array}$ & $\begin{array}{l}\text { Plantio Mecanizado } \\
\text { CCT terceirizado }\end{array}$ & $\begin{array}{l}\text { Plantio Manual } \\
\text { Terceirizado } \\
\text { CCT terceirizado }\end{array}$ \\
\hline
\end{tabular}

Fonte: Elaborado pelo autor

${ }^{18}$ Como optou-se por focar a análise no polo produtivo 2, todas as referências do produtor sobre a sua associação que forem descritas neste estudo, não se relacionam à Socicana e sim da Associação 2.

${ }^{19}$ Por ser o responsável pela gestão da propriedade em Jaboticabal, a maioria dos depoimentos do produtor 3 referem-se a esta região. 


\subsection{Objetivos de Negócio dos Entrevistados}

Ao analisar as declarações dos produtores sobre seus objetivos com a produção e fornecimento de cana-de-açúcar, é possível perceber, de forma geral, que a lucratividade e a sustentabilidade são os objetivos primordiais.

Espontaneamente, eles descreveram as estratégias para alcançar seus objetivos. Ou seja, buscando elevar sua performance operacional através da qualificação tecnológica e de gestão.

O Produtor 1, Integral / Grande, relatou que seus objetivos de negócio são buscar sustentabilidade econômica, social e ambiental através da qualificação e eficiência, além da atuação integrada junto aos outros produtores. Ele se diferenciou dos demais ao pontuar uma preocupação com a união dos produtores para fortalecer o setor. Ele reforça a necessidade de atuação integrada através do associativismo e do cooperativismo, para garantir o fortalecimento deste elo da cadeia.

\footnotetext{
"Os meus objetivos sempre foram, desde que eu nasci, desenvolver um trabalho competente, eficiente e profissional dentro do agronegócio brasileiro, mas sempre visualizando a sustentabilidade, econômica, social e ambiental. Ao ponto que, sempre em busca disso aí, a gente participa de todos os programas que existem de tecnologia, e sempre defendendo o associativismo e o cooperativismo. Porque não acreditamos que, independente de escala, nenhum produtor sozinho chega a lugar nenhum." Produtor Integral / Grande
}

O Produtor 2, Intermediário / Grande, relatou que o seu principal objetivo é o lucro e que, para alcançar melhores resultados, busca utilizar os melhores recursos e tecnologias para otimizar o que está sob o seu domínio, que é produtividade.

\footnotetext{
“O primeiro objetivo é fazer a parte da gente, né? Usar tudo o que está ao alcance, usar tecnologia. $O$ objetivo final é fazer dinheiro porque não significa nada fazer tudo certinho e no final o resultado não aparecer O lucro é o maior objetivo. (...). Onde a gente faz a diferença e a gente consegue ter aí um domínio maior é na produtividade." Produtor Intermediário / Grande
}

O Produtor 3, Intermediário / Grande, busca obter uma boa remuneração do seu negócio. $\mathrm{Na}$ avaliação do resultado, inclui o custo da remuneração da terra. Com este fim, ele atua para buscar uma alta produtividade e qualidade.

\footnotetext{
"Buscar uma alta produtividade, com cana com alto teor de ATR, qualidade e, claro, buscar sempre uma e boa remuneração do seu negócio. Esse é o nosso maior objetivo hoje.” Produtor Intermediário /
} 
O Produtor 4, Intermediário / Pequeno, relatou que seu objetivo é otimizar os lucros e, para alcançá-lo, busca qualificação para manter custos baixos.

“Todo mundo trabalha para ter lucro, né? Então o nosso não seria diferente. Então a gente tá buscando o que tem de top para manter o custo baixo e, assim, usar só o necessário, adubação ser feita por análise, calcário, gesso, para manter a tua terra estabilizada... Não adianta nada jogar adubo onde não tem cana. ” Produtor Intermediário / Pequeno

O Produtor 5, Básico / Pequeno, relatou que seu principal objetivo é a manutenção da propriedade através do lucro. Para isto, busca produzir as culturas que estejam remunerando melhor. Ele se diferenciou dos demais por colocar em primeiro lugar a manutenção da propriedade, demonstrando um elo afetivo com a propriedade familiar e uma preocupação com a continuidade para as próximas gerações.

\footnotetext{
"O objetivo nosso assim, é, primeiro você manter o negócio, né? Hoje pra você dar sequência, você tem que ter lucro. Que nem, a nossa propriedade aqui ela é quase que centenária, né? Desde 1927. Nós já estamos da 4a para a quinta geração. (...). Então qual que é o objetivo? Primeiro é manter o que ficou, dar sequência no negócio. As culturas vão variando de acordo com a situação. Aqui já plantou café, laranja, tomate. Hoje, por que que nos tamos na cana hoje? Porque é o que vem sendo viável, apesar das dificuldades. ” Produtor Básico / Pequeno
}

\subsection{Análise das experiências ao longo dos processos}

Citações foram utilizadas neste capítulo com bastante intensidade, com o propósito de criar maior proximidade do leitor com os pensamentos e sentimentos dos produtores. Optou-se por esta abordagem por estar alinhada com a metodologia de mapear experiências, nas quais citações são utilizadas com frequência durante as análises das experiências (KALBACH, 2017; JOHNSTON E KONG, 2011).

Ao final de cada etapa, através de um quadro, foram compiladas as percepções negativas e positivas, com identificação do produtor e dos atores do setor envolvidos.

\subsubsection{Planejamento Agrícola}

\subsubsection{Determinação da Vocação Técnica do Ambiente de Produção}

Todos os produtores entrevistados utilizam o serviço Carta de Solos, oferecido pela cooperativa. Através deste serviço, é realizada a caracterização do ambiente de produção, que 
envolve a classificação do solo e associação desta informação às condições de clima para, assim, alocar variedades de cana-de-açúcar mais responsivas.

O benefício mais destacado pelos produtores com a adoção do mapeamento de solos está relacionado à possibilidade de selecionar variedades que se adaptem melhor diferentes ambientes.

\footnotetext{
"Eu conheço o ambiente, conheço o meu solo, conheço o histórico de clima nosso. Então eu já sei quais variedades eu vou alocar, eu sei do potencial para explorar, as mais responsivas, menos responsivas. Sei o ambiente que é um pouco inferior. Eu vou colocar uma variedade um pouco mais rústica ali. Então eu faço esta gestão de alocar as variedades nas áreas.” Produtor Intermediário / Grande
}

\begin{abstract}
"Fiz a carta de solo. Esta carta de solo, ela me dá o tipo de solo que eu tenho na propriedade e o tipo de cana que eu posso plantar. Eu já tive problema de plantar uma variedade de cana e não dar produção e não saber por quê. Às vezes: ó essa cana é boa, e eu plantava e pra mim não dava.” Produtor Básico /
\end{abstract} Pequeno

“Tem muitas variedades de cana hoje. Muitas. Então a carta de solo me deu o tipo de cana que eu tenho que plantar. Então eu posso ir mudando.”Produtor Básico / Pequeno

O outro benefício da carta de solos também citado, está relacionado à correção do solo.

“70\% da área tem mapeamento de solo há 3 anos. Antigamente a gente fazia como? Chegava nessa área aqui e fazia tudo igual. Hoje não, você tem as áreas de solo. Então você põe realmente a quantidade de produto onde tem que pôr. Não põe a mais num lugar e nem a menos no outro, né?" Produtor Intermediário / Grande

O produtor Intermediário / Pequeno escolhe as suas variedades a partir de uma relação fornecida pela usina, combinando com as informações de ambiente da carta de solos.

"Nós temos que nos adequar dentro destas variedades, precoce e semi. A usina nos dá uma relação de
variedades. Como nós fizemos aquele mapa da terra, nós ficamos entre cinco variedades." Produtor Intermediário / Pequeno

Com relação às opções de variedades disponíveis no mercado, um fator levantado apenas pelos grandes produtores, é o ritmo insatisfatório e o custo elevado de desenvolvimento de variedades mais produtivas e mais resistentes. Eles comparam a cana aos avanços tecnológicos no desenvolvimento de variedades de grãos, principalmente soja.

\footnotetext{
"Eu acho que a parte tecnológica hoje, no setor sucroenergético, ela não tá avançado tanto quanto o grão, em matéria de cultivares de cana. A única coisa que eu vejo é que não tá tendo uma união entre órgãos de pesquisa e a cadeia produtiva para tentar amenizar custo pra investir na expansão do aspecto
} 
tecnológico, principalmente nas cultivares. Hoje, os órgãos de pesquisa, pra desenvolver uma variedade, envolve um custo altíssimo, o custo é muito alto'”. Produtor Integral / Grande

'Acho que falta ainda pesquisa. A soja, em 2002, a produtividade boa era 45-55 sacas. Hoje, tô produzindo 80 sacas. Em 15 anos, quase dobrou. Na cana, estou vendo o contrário." Produtor Intermediário / Grande

"Tá uma polêmica muito grande com royalties. A gente não consegue ter uma sequência nas variedades. Nós estamos carentes de variedades de cana mais produtivas e mais resistentes destas pragas todas. (...). A gente paga na soja também, mas tá satisfeito. Na cana não. Quando aparece alguma novidade aí, o preço vai lá no topo. " Produtor Grande / Intermediário

\subsubsection{Planejamento da Época da Colheita}

A maioria dos produtores terceirizam as atividades de corte, colheita e transporte (CCT) para as usinas e, por isso, seguem o seu calendário de colheita.

O produtor Integral / Grande participa de um contrato coletivo de fornecimento, via associação, em que é estabelecida uma cota diária de entrega para a usina. A sua colheita é realizada de acordo um planejamento de plantio e colheita integrado realizado pela associação. Considera adequado o processo de planejamento para definir a melhor época das colheitas. No entanto, atrasos na moagem da usina impactam a previsibilidade das operações.

\footnotetext{
"Nós fazemos a colheita. Então conseguimos colher a nossa cana, entrar na hora que achamos melhor. Lógico que com a ajuda da associação. A associação que direciona, que tem mais este conhecimento." Produtor Integral / Grande
}

A gente fazer o CCT tem essa vantagem de colher na hora que a gente quer. O problema disso é que a parte do T do transporte é a usina que faz. É uma empresa terceira da usina. Aí entram dois problemas. A moenda. É o maior problema é a moagem. A gente tem uma cota de cana pra pôr. Se a usina não mói, a gente não põe a cota e fura o nosso planejamento, que caba atrasando áreas, né? Produtor Integral /

\section{Grande}

Os demais produtores, que terceirizam o CCT para a usina, estabeleceram um acordo com quanto à época de realização da colheita. Com relação a este aspecto, as experiências são distintas entre os produtores.

Os dois produtores Grandes / Intermediários, que acordaram com a usina a realização da sua colheita precocemente, entre os meses de março e abril, estão satisfeitos. Um deles estabeleceu duas épocas de colheita. 
"Eu tenho um acordo com a usina. Eles colhem parte da cana em março e abril, e o restante até agosto. Não pode passar de agosto. ” Produtor Intermediário / Grande

Uma das vantagens de realizar a colheita precoce, segundo um dos produtores Intermediários / Grandes, é que ele pode plantar mais cedo e aproveitar a humidade da época das chuvas para melhorar a brotação. A outra vantagem é que, colhendo mais cedo, ele tem tempo para realizar outras atividades, como Meiosi ou rotação com safrinha.

\footnotetext{
"Um dos motivos de gente antecipar, é que assim, a gente sempre antecipou, por questões agronômicas, né? Porque é melhor pra planta, né? Colhe cedo, ainda tem humidade no solo, ela brota melhor." Produtor Intermediário / Grande

"Porque aqui, como a gente colhe em abril, maio, eu consigo fazer outras coisas, né? Consigo plantar soja bem mais cedo, eu posso plantar safrinha. A minha Meiosi, eu posso plantar na época que eu quero, praticamente. Posso fazer ela em julho, agosto.” Produtor Intermediário / Grande
}

Já o produtor Pequeno / Básico, que tem colheita tardia, demonstrou sofrer diversas restrições para realizar outras operações por não ter autonomia sobre a definição e sobre o cumprimento da época da acordada. Um dos aspectos relatados é que o tempo restante no calendário após a colheita não é suficiente para realizar a Meiosi, atividade que poderia levar a uma redução de custos com carregamento e transporte das mudas.

“Como a minha cana não cortou ainda, então não dá tempo de fazer a Meiosi. O que eu fiz? Eu fiz a Cantosi. Isso aí te aumenta o custo porque você vai precisar de guincho e caminhão. ”Produtor Pequeno / Básico

Outro aspecto apontado pelo mesmo produtor, é que, se a colheita atrasa, ele não consegue arrendar a terra para a realização da rotação de cultura e acaba tendo que fazer o preparo de solo convencional.

\footnotetext{
"Se, por um motivo ou outro eu não conseguir arrendar (para terceiros plantarem amendoim), que nem, a minha cana não cortou ainda._Pode ser que não dê mais tempo de plantar amendoim. Aí não vai ter a rotatividade. Aí eu mesmo preparo o solo: dessecação, aração, gradagem pesada e gradagem leve." Produtor Pequeno / Básico
}

O excesso de chuvas no final das safras é outro fator, pontado pelo produtor Básico / Pequeno, que pode impactar a qualidade da colheita e a concentração de ATR na cana. 
"O ideal é não fazer em período chuvoso. Que nem agora, período chuvoso, a minha cana não cortou ainda. Você precisa ficar mais atento. Se você sentir que o solo não tá bom, você não pode deixar eles entrar. ” Produtor Básico / Pequeno

“...que nem a minha cana não colheu ainda e tá chovendo. Ela vai ganhar peso. Ela vai cair o ATR.

Porque choveu ela tem água. Então ela vai diminuir o ATR...”

O quadro 2 resume as percepções levantadas na fase de Planejamento Agrícola.

Quadro 2 - Levantamento das percepções dos produtores relacionadas ao Planejamento Agrícola

\begin{tabular}{|c|c|c|c|c|}
\hline Atividade & Percepções & $\begin{array}{l}\text { Pos./ } \\
\text { Neg. }\end{array}$ & $\begin{array}{l}\text { Produtores } \\
\text { Entrevistados }\end{array}$ & $\begin{array}{l}\text { Agentes do } \\
\quad \text { setor } \\
\text { envolvidos }\end{array}$ \\
\hline $\begin{array}{l}\text { Mapeamento } \\
\text { do Solo }\end{array}$ & $\begin{array}{l}\text { Satisfação com o serviço de Carta de } \\
\text { Solos prestado pela cooperativa, em } \\
\text { parceria com a associação. }\end{array}$ & + & Todos os produtores & Associações \\
\hline $\begin{array}{l}\text { Pesquisa e } \\
\text { Desenvolvi- } \\
\text { mento de } \\
\text { Variedade }\end{array}$ & $\begin{array}{l}\text { Insatisfação com o ritmo e com os } \\
\text { custos das pesquisas e desenvolvimento } \\
\text { de variedades de cana. Ênfase na } \\
\text { questão de produtividade e resistência. }\end{array}$ & - & Grandes Produtores & $\begin{array}{l}\text { Centros de } \\
\text { melhoramen } \\
\text { to genético } \\
\text { da cana }\end{array}$ \\
\hline $\begin{array}{l}\text { Planejamento } \\
\text { da Época da } \\
\text { Colheita }\end{array}$ & $\begin{array}{l}\text { Produtores que conseguiram negociar a } \\
\text { época da colheita precoce com a usina } \\
\text { estão mais satisfeitos porque tem tempo } \\
\text { para realizar atividades como Meiosi }\end{array}$ & - & Intermediários/Grandes & Usinas \\
\hline $\begin{array}{l}\text { Planejamento } \\
\text { da Época da } \\
\text { Colheita }\end{array}$ & $\begin{array}{l}\text { O produtor também considera positiva a } \\
\text { colheita precoce por questões } \\
\text { agronômicas, já que a umidade que } \\
\text { permanece no solo ajuda na brotação. } \\
\text { Para alcançar estes resultados ele usa } \\
\text { variedades precoces. }\end{array}$ & - & Intermediário/Grande & Usinas \\
\hline $\begin{array}{l}\text { Planejamento } \\
\text { da Época da } \\
\text { Colheita }\end{array}$ & $\begin{array}{c}\text { A realização tardia da colheita } \\
\text { representa restrições para realizar outras } \\
\text { operações, tais como Meiosi e rotação } \\
\text { de culturas. }\end{array}$ & - & Básico / Pequeno & Usinas \\
\hline $\begin{array}{l}\text { Planejamento } \\
\text { da Época da } \\
\text { Colheita }\end{array}$ & $\begin{array}{l}\text { O excesso de chuvas no final da safra } \\
\text { impacta na qualidade da colheita e na } \\
\text { concentração de ATR da cana }\end{array}$ & - & Básico / Pequeno & Usinas \\
\hline $\begin{array}{l}\text { Planejamento } \\
\text { da Época da } \\
\text { Colheita }\end{array}$ & $\begin{array}{l}\text { Planejamento integrado de plantio e } \\
\text { colheita realizado pela associação. }\end{array}$ & + & Integral / Grande & $\begin{array}{l}\text { Usinas } \\
\text { Associação }\end{array}$ \\
\hline $\begin{array}{l}\text { Planejamento } \\
\text { da Época da } \\
\text { Colheita }\end{array}$ & $\begin{array}{l}\text { Atrasos na moagem impactam o } \\
\text { planejamento das operações. }\end{array}$ & - & Integral / Grande & Usinas \\
\hline
\end{tabular}

Fonte: Elaborado pelo autor 


\subsubsection{Organização de Recursos}

\subsubsection{Dimensionamento de Equipamentos}

O produtor Grande / Integral possui praticamente toda a estrutura de equipamentos e implementos própria. A única operação realizada pela usina é o transporte. Ele consegue otimizar a estrutura de plantio e colheita ao prestar serviços para outros produtores da mesma associação.

"Somos cinco produtores de cana que têm estrutura completa pra colher cana e pra plantar cana. Então, pra todos estes produtores aqui, esses cinco produtores de cana, dentro de uma governança, de um planejamento, colhem toda a cana do produtor e planta toda a cana do produtor." Produtor Integral / Grande

Os produtores Intermediários possuem estrutura de equipamentos e implementos para realizar todas as operações, com exceção do CCT. Para eles não compensa o alto investimento em estrutura e a dificuldade de diluir os custos através da escala de produção.

\footnotetext{
"Nós não fazemos o CCT. Não compensa a gente ter esta estrutura de colheita. É um investimento muito alto. Nós somos fornecedores próximo a cem mil toneladas de cana e as áreas não são todas no mesmo local. Se fosse tudo no mesmo local, justificaria nós termos a nossa frente de colheita para colher a nossa cana." Produtor Intermediário / Grande
}

O produtor Intermediário / Pequeno utiliza a colhedora do vizinho para realizar o corte de mudas mecanizado.

"Temos todos os equipamentos. A única coisa que não temos a colhedora de muda. Pagamos para o vizinho." Produtor Intermediário / Pequeno

Um dos produtores Intermediários / Grandes se preocupa em dimensionar adequadamente sua estrutura. Tem como referência um estudo, conduzido pelo PECEGE $^{20}$, em que foram levantados os custos operacionais e o lucro/prejuízo após a subtração dos custos com a remuneração da terra.

\footnotetext{
"Temos uma estrutura boa pra tocar isso, pequena, mas é aquilo que a gente precisa. Isso é importante, a gente dimensionar a estrutura, porque, às vezes, tem gente que tem uma estrutura muito inchada e não tá vendo que aquilo tá comendo todo o seu lucro. No estudo do PECEGE, o resultado desanimou né? Deu
}

\footnotetext{
${ }^{20}$ Instituto de Pesquisa Educação Continuada em Economia e Gestão de Empresas - Estudo sobre custos de produção de cana-de-açúcar de Produtores da Região Centro-Sul do Brasil Safra 2017/28.
} 
negativo por tonelada. E quais os custos maiores? Era o CCT e custo dos maquinários." Produtor Intermediário / Grande

Este mesmo produtor acredita haver oportunidade para otimizar ainda mais a estrutura através do compartilhamento de equipamentos ou prestação de serviços entre vizinhos por meio de um grupo ou aplicativo.

\footnotetext{
"Até uma das coisas legais. A gente teve uma ideia, uma época, de fazer um grupo. Por exemplo, eu tenho um trator com uma grade intermediaria de 28 dias, tal, tal, tal. Neste grupo, você coloca lá, disponível, custo tal. Aí eu sei que está disponível. Vamos supor, tá do meu lado e eu não sei. Ah! falha na comunicação! Daqui a pouco o cara te liga. Esta ideia não prosperou. Mas é uma ideia que a gente podia melhorar. (...) desenvolver um aplicativo alguma coisa que você possa tá otimizando mais equipamento, funcionário. Não tem.” Produtor Intermediário / Grande
}

O outro produtor Intermediário / Grande entrevistado também realiza algumas operações para vizinhos para otimizar a estrutura, como é o caso da colheita de soja. No entanto, acredita que, no seu porte, não há oportunidade para compartilhamento de equipamentos. A principal justificativa é que todos iriam precisar realizar as operações na mesma época.

O produtor Intermediário / Pequeno declarou que gostaria de trabalhar com uma estrutura bem mais enxuta se pudesse compartilhar equipamentos e operações com outros produtores. Chegou a mencionar um caso que tomou conhecimento sobre a organização de produtores através de condomínio.

\footnotetext{
"Na Europa, os vizinhos se juntam, todos preparam a terra juntos. Plantam com a mesma plantadeira, fazem uma sequência...Lá eles têm um trator grande, que nem nós temos 3 tratores grandes. Lá eles têm um para 10 propriedades. Um trator que custa 500 mil pra mim, ia custar 50 mil. É uma economia violenta, né? A manutenção, você manda na cooperativa, dá dez mil, divide e dá um mil pra cada um." Produtor Intermediário / Pequeno
}

O Produtor Básico / Pequeno conta com estrutura para fazer apenas os tratos culturais. Considera o investimento para adquirir equipamentos elevados diante de sua escala. Relatou que, com a oferta abundante de prestadores de serviço, a opção mais comum é contratar serviço de terceiros.

\footnotetext{
"Porque não é todo equipamento que você consegue ter, né? Às vezes você compra um equipamento e você vai usar uma vez por ano... Hoje se você pegar o maquinário, óleo diesel, é muito caro pra você fazer esse tipo de serviço. Então, geralmente, se você precisa de um serviço, e o teu equipamento não serve, você acaba contratando.” Produtor Básico / Pequeno
} 
"Se eu precisar de um equipamento emprestado do vizinho, eu até consigo. Se algum vir buscar aqui, eu também empresto. Mas hoje, isso é muito raro... a questão é que hoje isso é pouco utilizado. Por quê? Porque tem muito prestador de serviço." Produtor Básico / Pequeno

\subsubsection{Planejamento e Compra de Insumos}

Com exceção do produtor Integral / Grande, que conta com técnicos da sua própria estrutura organizacional para realizar o planejamento da compra de insumos, os demais contam com os serviços das cooperativas para planejar e comprar os insumos. Eles estão satisfeitos com o serviço. A sua dor está relacionada à oscilação de preço da matéria prima no mercado.

\footnotetext{
“Com relação aos insumos, recorro muito à cooperativa. Ela nos atende bem, desde a parte técnica, com apoio dos técnicos, agrônomos que dão acompanhamento. A gente acaba discutindo junto. “Ó, preciso reduzir custo. Posso usar um adubo mais barato?" Se usar isso, depois tem que gastar com isso. E a gente acaba chegando a um bom senso, para fazer de uma forma econômica, sem perder a qualidade."
}

\section{Produtor Intermediário / Grande}

"Nós temos a cooperativa, tem o agrônomo, tem o produto, tem o financiamento que você quer, tem o prazo, se quiser pagar à vista. Não vejo problema. O único problema hoje que a gente vê é a variação de preço, né? Por causa do mercado, né? Você tem um insumo agrícola que o ano passado custava uma coisa e esse ano subiu. A dificuldade hoje tá no preço, né? É custo, não o serviço prestado." Produtor

\section{Básico / Pequeno}

\subsubsection{Levantamento de Recursos Financeiros}

Dois produtores declararam realizar a maior parte das transações de compra à vista.

“A gente tem uma característica de produtores mais conservadores, ou seja, é capitalizado. A gente hoje faz $70 \%$ das compras à vista. Não fica fazendo financiamento. Quando vocêfinancia, você tem um preço de partida já maior, mais a taxa e aquilo ali. É melhor negociar um desconto maior." Produtor Intermediário / Grande

“Hoje banco não compensa. É o que eu falo, junta dinheiro, espera dois, três, e paga à vista que você faz uma puta de uma negociação. Desde 2005 a gente não usa crédito bancário. A gente faz um orçamento, vê o que que dá pra fazer, o que que é prioridade pra ser feito. ” Produtor Intermediário /

\section{Pequeno}

As cooperativas de crédito foram citadas como uma boa alternativa para captar recursos financeiros, por oferecem taxas de juros diferenciadas, além distribuir sobras. 
“Eu participo da cooperativa de crédito. É uma forma legal de trabalhar porque você ganha mais que o mercado se emprestar e paga menos juros ao pegar empréstimo. Além disso tem uma distribuição de sobras no final." Produtor Intermediário / Grande

"O crédito a gente consegue nos bancos cooperados, né? Então quanto à crédito rural, a gente consegue sim. Esses bancos cooperados, a taxa de juros é bem menor que um banco normal." Produtor Básico / Pequeno

Além deste ponto, um dos produtores considera que as cooperativas estão bem estruturadas, atuando de forma conservadora. Por outro lado, a dificuldade está na limitação dos montantes a serem tomados, já que exigem mais garantias.

\footnotetext{
"Hoje eu acho que as cooperativas estão bem estruturadas. A governança é conservadora. Eu sou 80 $70 \%$ conservador e 20-30\% aventureiro. Eles são bem conservadores, mas as dificuldades é você captar recurso. Você tem alguns limites, você não consegue emprestar ou tomar muito mais que aquilo. São as dificuldades: garantias maiores. " Produtor Intermediário / Grande
}

O produtor Integral / Grande acredita que haveria maior acesso de crédito para os produtores se as instituições financeiras valorizassem mais o ativo biológico, considerando os contratos e relacionamentos estabelecidos com indústrias sólidas.

\begin{abstract}
“Eu acho que ano a ano os bancos estão dificultando a concessão de crédito para os produtores, tá certo? Principalmente quem é voltado à cadeia produtiva, à produção do ativo biológico, tá? Hoje você vai num banco falar que você é um grande produtor, que você tem um grande ativo biológico, esse ativo biológico não é valorizado perante os bancos. O que que eles querem? Garantia real, eles querem patrimônio. (...) eu acho que um produtor que tem um bom ativo biológico, é parceiro de uma boa indústria... Eles não pegam como uma garantia de uma concessão de crédito. ” Produtor Integral / Grande
\end{abstract}

O quadro 3 resume as percepções levantadas durante as atividades de Organização de Recursos.

Quadro 3 - Levantamento percepções dos produtores relacionadas à Organização de Recursos

\begin{tabular}{|c|c|c|c|c|}
\hline Atividade & Percepções & $\begin{array}{c}\text { Pos./ } \\
\text { Neg. }\end{array}$ & $\begin{array}{c}\text { Produtores } \\
\text { Entrevistados }\end{array}$ & $\begin{array}{c}\text { Agentes do } \\
\text { setor } \\
\text { envolvidos }\end{array}$ \\
\hline $\begin{array}{c}\text { Dimensionamento } \\
\text { de Equipamentos }\end{array}$ & $\begin{array}{c}\text { O elevado investimento em estrutura } \\
\text { de CCT não compensa pela escala. }\end{array}$ & - & $\begin{array}{c}\text { Intermediários/Grandes } \\
\text { Intermediário/Pequeno } \\
\text { Básico/Pequeno }\end{array}$ & Usinas \\
\hline
\end{tabular}




\begin{tabular}{|c|c|c|c|c|}
\hline Atividade & Percepções & $\begin{array}{l}\text { Pos./ } \\
\text { Neg. }\end{array}$ & $\begin{array}{l}\text { Produtores } \\
\text { Entrevistados }\end{array}$ & $\begin{array}{l}\text { Agentes do } \\
\text { setor } \\
\text { envolvidos }\end{array}$ \\
\hline $\begin{array}{l}\text { Dimensionamento } \\
\text { de Equipamentos }\end{array}$ & $\begin{array}{c}\text { O produtor tem estrutura completa } \\
\text { que é otimizada ao realizar as } \\
\text { operações de plantio e colheita para } \\
\text { outros associados. Esta prática ocorre } \\
\text { dentro de um modelo de realização } \\
\text { de operações coletivas, organizado } \\
\text { pela associação. }\end{array}$ & + & Integral/Grande & Associação \\
\hline $\begin{array}{l}\text { Dimensionamento } \\
\text { de Equipamentos }\end{array}$ & $\begin{array}{l}\text { Poderia trabalhar com uma estrutura } \\
\text { mais enxuta se houvesse } \\
\text { compartilhamento entre vizinhos. } \\
\text { Tem referência de modelo de } \\
\text { condomínio. }\end{array}$ & - & Intermediário/Pequeno & - \\
\hline $\begin{array}{l}\text { Dimensionamento } \\
\text { de Equipamentos }\end{array}$ & $\begin{array}{l}\text { Vê oportunidade de otimização de } \\
\text { estrutura e funcionários através de } \\
\text { um grupo ou aplicativo de } \\
\text { compartilhamento e prestação de } \\
\text { serviços entre vizinhos. }\end{array}$ & - & Intermediário/Grande & $\begin{array}{l}\text { Plataforma de } \\
\text { compartilham } \\
\text { ento }\end{array}$ \\
\hline $\begin{array}{l}\text { Dimensionamento } \\
\text { de Equipamentos }\end{array}$ & $\begin{array}{l}\text { Possui estrutura para realizar apenas } \\
\text { os tratos culturais. Utiliza serviços de } \\
\text { terceiros, cuja oferta é abundante. }\end{array}$ & + & Básico/Pequeno & $\begin{array}{l}\text { Prestadores } \\
\text { de Serviço }\end{array}$ \\
\hline $\begin{array}{l}\text { Planejamento e } \\
\text { Compra de } \\
\text { Insumos }\end{array}$ & $\begin{array}{l}\text { Apoio técnico da cooperativa para } \\
\text { planejar os insumos e melhores } \\
\text { condições de compra }\end{array}$ & + & $\begin{array}{l}\text { Intermediário/Grande } \\
\text { Intermediário/Pequeno } \\
\text { Básico/Pequeno }\end{array}$ & Cooperativas \\
\hline $\begin{array}{l}\text { Planejamento e } \\
\text { Compra de } \\
\text { Insumos }\end{array}$ & $\begin{array}{l}\text { A maior dificuldade é o preço dos } \\
\text { insumos que oscila muito. }\end{array}$ & - & $\begin{array}{l}\text { Intermediário/Grande } \\
\text { Intermediário/Pequeno } \\
\text { Básico/Pequeno }\end{array}$ & Cooperativas \\
\hline $\begin{array}{l}\text { Levantamento de } \\
\text { Recursos } \\
\text { Financeiros }\end{array}$ & $\begin{array}{l}\text { Produtores procuram realizar a } \\
\text { maioria das compras à vista, evitando } \\
\text { pagamentos de juros. }\end{array}$ & + & $\begin{array}{l}\text { Intermediário/Grande } \\
\text { Intermediário/Pequeno }\end{array}$ & $\begin{array}{l}\text { Bancos } \\
\text { Cooperativas } \\
\text { de Crédito }\end{array}$ \\
\hline $\begin{array}{l}\text { Levantamento de } \\
\text { Recursos } \\
\text { Financeiros }\end{array}$ & $\begin{array}{l}\text { Cooperativas de crédito são boas } \\
\text { alternativa para captar recursos } \\
\text { financeiros, por oferecem taxas de } \\
\text { juros diferenciadas, além distribuir } \\
\text { sobras. }\end{array}$ & + & $\begin{array}{l}\text { Intermediário/Grande } \\
\text { Básico/Pequeno }\end{array}$ & $\begin{array}{l}\text { Cooperativas } \\
\text { de Crédito }\end{array}$ \\
\hline $\begin{array}{l}\text { Levantamento de } \\
\text { Recursos } \\
\text { Financeiros }\end{array}$ & $\begin{array}{l}\text { O montante a ser tomado através de } \\
\text { cooperativas de crédito é limitado. } \\
\text { As garantias são maiores. }\end{array}$ & - & Intermediário/Grande & $\begin{array}{l}\text { Cooperativas } \\
\text { de Crédito }\end{array}$ \\
\hline $\begin{array}{l}\text { Levantamento de } \\
\text { Recursos } \\
\text { Financeiros }\end{array}$ & $\begin{array}{l}\text { O ativo biológico deveria ser mais } \\
\text { valorizado pelas instituições } \\
\text { financeiras. }\end{array}$ & - & Intermediário/Grande & $\begin{array}{l}\text { Cooperativas } \\
\text { de Crédito }\end{array}$ \\
\hline
\end{tabular}

Fonte: Elaborado pelo autor 


\title{
6.3.3 Produção de Mudas
}

Distintas práticas e percepções foram identificadas em relação aos sistemas de produção de mudas dos entrevistados. Dos cinco entrevistados, dois produzem suas próprias mudas através da tecnologia MPB associada à Meiosi e os outros três utilizam o método convencional de produção de muda associado à CANTOSI.

Os dois produtores que produzem suas próprias mudas através da tecnologia MPB estão satisfeitos com o método nos quesitos relacionados à qualidade, à sanidade das mudas e ao custo. Um deles fez as seguintes declarações:

“É trabalhoso, né? Mas é desafiante, é bom, dá resultado, tanto econômico, quanto na produção final. A Meiosi ajuda muito a reduzir o custo do plantio, além da sanidade da muda. Não tem o custo do transporte." Produtor Intermediário / Grande

“Às vezes você pegava qualquer cana e virava muda. Hoje a MPB é uma semente tratada, desinfetada, enfim. Antigamente não. Eu ia lá na tua fazenda e pegava, ou você pegava na minha e levava e não sabia o que tava levando para a fazenda. Hoje você tem um controle maior com isso." Produtor Intermediário / Grande

O outro produtor evidenciou matematicamente a economia de custos que ele tem na implantação do canavial ao adotar MPB combinada com MEIOSI.

\begin{abstract}
"Se você plantar no convencional, você consegue multiplicar um hectare de muda para aproximadamente 7 (1:7). Só que um ha (multiplicou ton/ha x ATR/ton x Preço do ATR) daria R\$14.823, dividido por 7, vai dar uns $R \$ 2.000$ por ha. Um ha, eu gasto 11.000 mudas, à $R \$ 1 /$ muda. Só que um ha (com MPB), faço uma taxa de desdobra de 1:14, mais o que eu já plantei, que é 1 ha da Meiosi, eu vou ter 15 ha para dividir. $R \$ 11.000 / 15$, deu $R \$ 733$ por hectare, contra $R \$ 2.000$ no plantio convencional. Só aqui a economia foi de $R \$ 1.270,00$. Só aqui, na muda. Então não é caro. E tem outra coisa que é que você tá levando uma cana sadia, livre de doenças.” Produtor Intermediário / Grande.
\end{abstract}

Adicionalmente, ele considerou também a economia com o transporte, proporcionado pelo sistema Meiosi.

\footnotetext{
“Eu ainda consegui fazer uma economia em torno de $R \$ 400$ / ha na mão de obra porque o pessoal só tem que cortar cana e colocar no sulco. Antigamente tinha que transportar, dava muito trabalho, era muita gente. Aí não tenho caminhão nem carregadeira, que vai dar uns R\$1300 /alqueire. Só o caminhão e a carregadeira. No frigir dos ovos, eu consigo economizar em torno de $R \$ 1700 /$ ha na implantação do canavial.” Produtor Intermediário / Grande.
} 
Em relação às MPBs, uma das principais dificuldades relatadas pelos entrevistados é a tecnologia de plantio. Diante da insatisfação com as plantadeiras disponíveis no mercado, um dos produtores adaptou um equipamento na própria fazenda, mas que também não atende às suas necessidades.

\footnotetext{
"O problema maior hoje com MPB é equipamento para plantio, as plantadeiras não satisfazem, tanto em qualidade, quanto em rendimento. A gente precisa de equipamento. Tem gente que ainda faz manual, mas é o pior de todos. A gente desenvolveu uma plantadeira lá na própria fazenda, com as peças do ferro velho para quebrar o galho. Peguei uma plantadeira de cereais e transformei em numa plantadeira de MPB e estamos sobrevivendo. Mas eu acho assim, que esta plantadeirinha de cana que o mercado oferece pra gente que é a matraca de 30 anos atrás, ainda precisa evoluir muito." Produtor Intermediário I Grande
}

Por outro lado, outro produtor, que também fez uma adaptação da semeadeira na fazenda, está bastante satisfeito com os resultados do equipamento.

\footnotetext{
"Pegamos uma semeadeira e fizemos uma transplantadora. E aí começamos a transplantar. E aí, conforme funcionou, peguei e fiz o viveiro. Porque o pessoal hoje, nas usinas, muita gente planta tudo na matraca, que é plantar na mão. A minha adapta no trator, acopla no trator. Tem as linhas e aí eu vou plantando. Tem uma pessoa sentada vai girando, vai pondo as mudas e plantando. Então assim, eu tenho rendimento, menos gente. Ah, melhora.” Produtor Intermediário / Grande
}

Outro aspecto questionado é se compensa produzir MPB ou comprar a muda pronta de viveiros. Um dos produtores reavalia se valeu a pena.

\begin{abstract}
"Eu não acho que o produtor de cana precisa fazer o viveiro. Eu, repensando, eu já vou para o terceiro ano, eu acho que eu não faria o viveiro. Ah, imagina, eu tenho que manter um funcionário o ano todo $e$ eu não produzo o ano todo. Compensa? Eu não sei se vale tão a pena assim. Você vai lá, compra as mudas, numa Singenta, numa Basf, acabou. Você não precisa manter uma estufa, pagar energia elétrica, comprar adubo, insumos, é um monte de coisa. (...). Para o custo compensar, eu preciso ter um x volume de venda. Eu já fiz essas contas. ” Produtor Intermediário / Grande
\end{abstract}

Já o outro produtor não quer depender da disponibilidade de mudas no mercado, por isso acha que compensa a produção própria de mudas.

\footnotetext{
“Compensa, para não depender da disponibilidade nos viveiros. Muitas vezes falta muda no mercado. É melhor ter tudo sob controle. Não depender.” Produtor Intermediário / Grande
}

Um dos produtores que optou pelo plantio convencional considera o investimento e o custo das MPBs elevado. 
“Nós entramos neste projeto em 2014, 2015. Mas não vingou porque ia necessitar de mão de obra e estrutura grande. O setor tá numa crise aí, vem se arrastando há alguns anos e isso aí... eu até sei a parte agronômica, a qualidade da muda, tem os seus prós, mas não estamos usando, devido a custo na realidade. Plantar cana inteira se torna bem mais barato.” Produtor Integral / Grande

Ele acredita que poderia produzir a própria muda para reduzir custos. No entanto, ainda considera a operação manual e complexa.

\footnotetext{
“Aí eu vou lá e eu faço o canteirinho, o canteiro. Faço tudo manual. Aí eu planto a pré-brotada. Aí eu espero formar aquela muda lá, depois eu vou lá e pego ela e vou replantar. São três operações. Isso aí é pra minimizar custo. É um custo menor. Agora, se as pessoas querem ficar aqui, compra bastante. Hoje deve estar quanto, uns $R \$ 2,5$ ou 3 cada mudinha. Compra bastante cana lá e vai lá e solta tudo lá pra plantar. Se ele quiserem fazer isto? Mas isso daí, tá faltando planejamento. Aí onera muito.” Produtor Integral / Grande
}

Por outro lado, ele acredita nos benefícios da tecnologia e pretende implementar no futuro, de acordo com o avanço da tecnologia.

“Mas, eu acho que (MPB) é um belo projeto. Eu acho que esse processo aí é irreversível, em função da qualidade da muda. Precisa avançar um pouco na tecnologia, em matéria de máquinas para plantar, precisamos avançar na tecnologia para plantio.” Produtor Integral / Grande.

Com relação à Meisoi, o produtor não considera um bom sistema para a produção em grande escala pois acredita que o herbicida, utilizado na cultura de rotação, pode agredir a cana da Meisoi.

\footnotetext{
"Por que nós optamos pela Cantosi? Em razão da escala que nós temos. A gente viu que a Meisoi na escala que nós estamos não se adaptou muito bem. Em razão da rotação de cultura, em razão da operacionalidade na grande escala que nós temos. (...). O problema é a questão da soja com a Meiosi. Porque a gente usa Roundup na soja e pode matar a cana. Tem maus exemplos em áreas de usina em que não dá multiplicação. No outro ano fica faltando cana. ” Produtor Integral / Grande.
}

Já o produtor Intermediário / Pequeno, testou a Meisoi, só que com mudas convencionais, pois considera as MPBs caras. Além disso, considerou o processo trabalhoso optou por produzir em canteiro.

“Já tentamos a MEIOSI. Mas não estamos contentes com ela não. Ah, muito trabalhosa. Nós plantamos, faltou chuva, você precisa ficar irrigando. Nós não plantamos MPB, nós plantamos cana mesmo. Quando é MPB, ainda acho que fica melhor. Eu acho que ainda tá meio caro. A muda MPB é cara, R\$ 1,1 cada muda. e ainda o trator com GPS é um investimento de mais de $R \$ 70$ mil e eu acho que é muito investimento pra pouco tempo de uso.” Produtor Intermediário / Pequeno 
O produtor Intermediário / Grande, que utiliza a Meiosi, também relata que a Meisoi requer cuidados especiais e demanda mais trabalho. Ele destaca a questão da irrigação. No entanto, ele já adotou uma técnica, que é o gel de rega, que gera uma redução de custo e redução do trabalho.

"Claro, tratamos a Meisoi igual a um bebezinho. Nós cuidamos muito bem dela. Se tiver alguma lagarta, tem que controlar, fazemos 3 adubações...Tem que estar consciente de que você vai ter que trabalhar mais. Você vai ter que plantar suas mudinhas, aguar suas mudinhas, todo dia ou talvez dia sim, dia não. Existem técnicas para melhorar o molhamento dessas mudas com gel de rega, coisas que eu já uso, que eu consigo, aguar menos vezes e aí eu consigo ter mais tempo do funcionário pra fazer outro serviço, consumo menos diesel". Produtor Intermediário / Grande

O produtor Básico / Pequeno também reconheceu este benefício, embora não adote o sistema, por uma limitação da época da colheita.

“Como a minha cana não cortou ainda, então não dá tempo de fazer a Meisoi. O que eu fiz? Eu fiz a Cantosi. Isso aí te aumenta o custo porque você vai precisar de guincho e caminhão." Produtor Básico / Pequeno

O quadro 4 resume as percepções levantadas na fase de Produção de Mudas.

Quadro 4 - Levantamento das percepções dos produtores relacionadas à Produção de Mudas

\begin{tabular}{|c|c|c|c|c|}
\hline Atividade & Percepções & $\begin{array}{l}\text { Pos. } \\
\text { /Neg }\end{array}$ & $\begin{array}{l}\text { Produtores } \\
\text { Entrevistados }\end{array}$ & $\begin{array}{l}\text { Agentes do setor } \\
\text { envolvidos }\end{array}$ \\
\hline MPB & $\begin{array}{l}\text { Reconhecimento dos benefícios } \\
\text { relacionados à qualidade e à sanidade da } \\
\text { MPB. }\end{array}$ & + & $\begin{array}{c}\text { Integral/Grande } \\
\text { Intermediários/Grandes }\end{array}$ & \multirow{3}{*}{$\begin{array}{l}\text { Centros de } \\
\text { pesquisa } \\
\text { Viveiros } \\
\text { Associações }\end{array}$} \\
\hline MPB & $\begin{array}{l}\text { Redução significativa de custo de } \\
\text { implantação do canavial com MPB } \\
\text { aliado à Meiosi. }\end{array}$ & + & Intermediários/Grandes & \\
\hline MPB & Custo elevado das mudas MPB & - & $\begin{array}{c}\text { Integral/Grande } \\
\text { Intermediário/Pequeno }\end{array}$ & \\
\hline MPB & $\begin{array}{l}\text { Produzir a própria muda reduz custo, } \\
\text { porém a operação é manual complexa, } \\
\text { além de demandar um investimento } \\
\text { inicial em estrutura e funcionário. }\end{array}$ & - & Integral / Grande & $\begin{array}{l}\text { Centros de } \\
\text { pesquisa } \\
\text { Viveiros } \\
\text { Associações }\end{array}$ \\
\hline MPB & $\begin{array}{l}\text { Tecnologia para plantio de MPB } \\
\text { insatisfatórias, com baixa qualidade e } \\
\text { rendimento. }\end{array}$ & - & Intermediário/Grande & $\begin{array}{l}\text { Fabricantes de } \\
\text { equipamentos }\end{array}$ \\
\hline MPB & $\begin{array}{c}\text { Resultados positivos com a adaptação de } \\
\text { semeadeira em transplantadora para o } \\
\text { plantio }\end{array}$ & + & Intermediário/Grande & $\begin{array}{l}\text { Fabricantes de } \\
\text { Equipamentos }\end{array}$ \\
\hline
\end{tabular}




\begin{tabular}{|c|c|c|c|c|}
\hline Atividade & Percepções & $\begin{array}{l}\text { Pos. } \\
\text { /Neg }\end{array}$ & $\begin{array}{l}\text { Produtores } \\
\text { Entrevistados }\end{array}$ & $\begin{array}{l}\text { Agentes do setor } \\
\text { envolvidos }\end{array}$ \\
\hline MPB & $\begin{array}{l}\text { Vale mais a pena produzir MPB do que } \\
\text { comprar para não depender da } \\
\text { disponibilidade nos viveiros. Muitas } \\
\text { vezes falta muda no mercado. }\end{array}$ & + & Intermediário/Grande & Viveiros \\
\hline MPB & $\begin{array}{c}\text { Talvez não compense ter viveiro e } \\
\text { manter toda uma estrutura, funcionário } \\
\text { etc. Seria mais fácil comprar as mudas } \\
\text { prontas. }\end{array}$ & - & Intermediário/Grande & Viveiros \\
\hline Meiosi & $\begin{array}{l}\text { Redução de custos de carregamento e } \\
\text { transporte com a Meiosi }\end{array}$ & + & Todos & \\
\hline Meiosi & $\begin{array}{c}\text { Percepção de que Meiosi não compensa } \\
\text { em grande escala. Um dos motivos é a } \\
\text { contaminação com herbicidas da cultura } \\
\text { de rotação. }\end{array}$ & - & Integral/Grande & \\
\hline Meiosi & $\begin{array}{c}\text { Meiosi é trabalhoso e tem que fazer } \\
\text { irrigação }\end{array}$ & - & Pequeno/Intermediário & \\
\hline Meiosi & $\begin{array}{l}\text { Utilização de gel de rega para reduzir a } \\
\text { necessidade de irrigação e os gastos }\end{array}$ & + & Grande/Intermediário & $\begin{array}{l}\text { Fornecedores de } \\
\quad \text { insumos }\end{array}$ \\
\hline Meiosi & $\begin{array}{c}\text { Elevado investimento em equipamento } \\
\text { com georreferenciamento para fazer a } \\
\text { Meiosi }\end{array}$ & - & Pequeno/Intermediário & \\
\hline
\end{tabular}

Fonte: Elaborado pelo autor

\subsubsection{Conservação e Preparo do Solo}

\subsubsection{Conservação do Solo}

Os produtores consideram o processo de sistematização das áreas de plantio fundamental para otimizar as operações mecanizadas, reduzindo manobras, gasto de tempo, combustível e perdas de insumos e matéria prima.

O produtor Integral / Grande reduzir bastante suas perdas de colheita com a sistematização.

Melhoramos muito (a redução das perdas) na cana, em razão da evolução da sistematização do solo. Isso que eu falo pra eles lá. Não foi nada de máquina, estas coisas não. Foi a evolução que nós fizemos na sistematização do solo. (...). Usamos $100 \%$ piloto automático, tanto na colheita, quanto plantio."

\section{Produtor Integral / Grande}

“A sistematização influencia no plantio mecanizado, influencia na colheita mecanizada. Acho que pra mensurar a qualidade do equipamento, seja a colhedora, seja a plantadora, o início de tudo é na sistematização de solo. Começou errado ali, vai dar tudo errado. Aí eu dou razão para os fabricantes de equipamentos. ” Produtor Integral / Grande 
O produtor Intermediário / Grande já sistematizou quase 100\% das suas áreas, recebendo orientação da usina.

"Já fazemos (a sistematização) faz tempo, inclusive nossas áreas hoje são de alto rendimento. Esse é um ponto forte que a usina nos orienta. Tudo o que eles fazem, eles estão disponibilizando para a gente fazer, mesmo porque é de interesse deles também. Porque eles que vão fazer a colheita. Hoje estamos com quase $100 \%$ da área. (...). Eles fornecem só a orientação e alguma coisa em termos de pen drive, das curvas. (...). Inclusive a associação está começando a fazer hoje." Produtor Intermediário / Grande

O produtor Intermediário / Pequeno também teve apoio da usina na realização da topografia e considera que vem obtendo ganhos em diversas etapas da operação.

"Foi feita a topografia pela usina. Foram eliminadas um monte de curvas, foi feito terraço de base larga, foi diminuído número de carreadores. Temos tiro de quase 2000 metros. Aumenta a agilidade da colheita. Não só da colheita, da adubação, reduz combustível e não perde tanto veneno. Eles te entregam um mapa AB, passa o GPS, tira o desnível. Trazem o mapa e jogam no GPS do trator e faz o Sistema AB e planta."

\section{Produtor Intermediário / Pequeno}

O outro produtor Intermediário / Grande está executando um projeto de sistematização da sulcação da meiosi e da colheita. Ele espera reduzir bastante as falhas da colheita quando as máquinas colhedoras da usina também utilizarem o piloto

\footnotetext{
"Então eu já tô fazendo toda a minha área. Ainda não são todas. Toda a minha reforma agora tá sistematizada. Por exemplo, quando eu for plantar cana, eu já tenho tudo pronto: o projeto de sulcação, o projeto da Meisoi, o projeto da colheita.” Produtor Intermediário / Grande

"Na hora que a usina vier colher, se ela tiver condições de entrar com uma máquina com piloto automático, que converse com o meu piloto, do trator meu, aí vão entrar e vão colher esta área com tudo em cima do projeto, então vem sinal de satélite, tem o projeto, tudo certinho. Vai ter menos pisoteio, vai ter melhor eficiência de colheita e maior longevidade do canavial, né?’' Produtor Intermediário / Grande
}

O produtor Básico / Pequeno preocupa-se em evitar a erosão e garantir a manutenção das estradas.

\footnotetext{
“Hoje as curvas estão prontas, eu só reformo elas. Se eu quiser mudar alguma curva, por exemplo, ah eu tô tendo erosão aqui. Aí ele (rapaz da cidade que faz a topografia) vem aí, ele faz uma curva. Ele vê onde tem que fazer certinho para proteger as estradas. Para você corrigir se tá correndo água num lugar ou outro. Isso aí hoje tem que ter. Já não pode mais, né?” Produtor Pequeno / Básico
} 


\subsubsection{Correção do Solo}

Com base nas análises do solo, os produtores fazem a correção com calcário e gesso. Um dos produtores relatou utilizar também a fosfatagem na reforma.

"A gente faz as análises de solo e faz a correção. Usamos calcário e gesso. A fosfatagem só fazemos quando vamos fazer o plantio da cana." Produtor Intermediário / Grande

“A correção é feita através da análise do solo. Calcário e Gesso. Mais é calcário, né? Gesso é menos, mas também costumo utilizar sim, mas com bem menos frequência." Produtor Básico / Pequeno

“Já vai tirando a cana e já vai fazendo análise. Todo ano esparrama calcário. Todo ano ímpar a gente joga gesso. O meu pai tinha essa mania de que no ano ímpar era o certo para o gesso." Produtor Intermediário / Pequeno

O produtor Intermediário / Grande relatou que obteve ganhos de produtividade quando começou a fazer a correção com calcário e gesso também na cana soca.

"Eu acho que o principal é calcário e gesso. E a gente faz 50\% da área em um ano e $50 \%$ em outro ano. Em dois anos a gente faz $100 \%$ da área. Também na cana soca, ano sim e ano não. Analisa e corrige. A gente não espera mais reforma. Antigamente se usava fazer só nas reformas. Depois que a gente começou a fazer a cada dois anos, a produtividade melhorou e muito." Produtor Intermediário / Grande

O outro produtor Intermediário / Grande vê uma oportunidade de melhoria desta operação através da agricultura de precisão, fazendo uso de taxa variável a partir de mapeamento aéreo com drones, para distribuir os fertilizantes de acordo com a necessidade de cada ambiente.

\footnotetext{
“Em termos de agricultura de precisão, eu poderia fazer uma taxa variável que a gente fala, né? Com o piloto e mais a taxa variável, reconhecendo o que eu tenho de ambiente. Exemplo: eu tenho uma área que demanda 2 toneladas de calcário, eu vou jogar duas. No mesmo talhão, que precisa 3, ele já começa a jogar 3, automaticamente ele já passa a jogar 3. Então, ele mesmo já faz esta correção. Eu ainda não faço isso." Produtor Intermediário / Grande
}

Com relação à torta de filtro e à vinhaça, alguns produtores, que têm cota da usina, utilizam porque acreditam que obtém benefícios agronômicos.

\footnotetext{
"Aí a gente faz a análise de solo para ver a necessidade de calcário e a necessidade de produtos químicos. Nós temos um convenio com as usinas de fornecimento de torta de filtro. A gente busca a cota nossa de torta de filtro na usina. Já ajuda, né? Isso aí é matéria orgânica, ajuda na adubação orgânica. ” Produtor Integral / Grande
} 
"Torta de filtro eu uso pouco, a não ser que gente mecha em alguma curva, que a gente tenha que remover solo a gente acaba utilizando. (...). A fertirrigação com a vinhaça a usina faz e só pagamos para ela. Usamos um serviço que a usina oferece pra gente. " Produtor Intermediário / Grande

No entanto, um deles, que teria direito à cota, é mais cético quanto aos resultados e prefere não utilizar.

"Torta de filtro, essas coisas, a usina disponibiliza, mas aí começa... Começa a fornecer de graça, mas aí começa a pedir alguma coisa em troca. Então a gente descarta isso aqui. (...) A usina usa isso aí mesmo porque acha que tem que sumir com isso. Mas é bem pobre como fertilizante. Tem que usar um monte para dar um resultado pequeno. Apesar de que a gente não usa, então a informação que a gente tem sobre isso aí é muito pouca." Produtor Intermediário / Grande

O produtor Intermediário / Pequeno não tem a cota de subprodutos da usina e considera que ajudaria na adubação do solo.

"Nós não temos direito à torta, nós não temos direito à bagaço, à vinhaça. A Vinhaça é rica em Potássio. A torta de filtro pra plantio você diminui a quantidade de adubo. " Produtor Intermediário / Pequeno

Este mesmo produtor está testando utilizar esterco de galinha com o objetivo de reduzir a quantidade de adubo químico.

"Estou usando esterco de galinha. (...). É nítida a diferença. Cresceu mais de 2 palmos em relação ao outro talhão. Mas precisamos ainda ver na hora da colheita... Peguei esta ideia na Internet. Lá no Paraná, a Usina Santa Terezinha está economizando quase $40 \%$ da adubação química, usa esterco das granjas. O que aparece de novidade, a gente procura saber e ver. Eu vou navegando e achando."

\section{Produtor Intermediário / Pequeno}

\subsubsection{Preparo do Solo}

Com relação às atividades de preparo do solo, todos os entrevistados buscam trabalhar com o cultivo reduzido, fazendo uso de rotação de cultura como prática de conservação do solo.

\footnotetext{
"Procuro revolver o mínimo possível o solo. Quanto mais você meche, você perde matéria orgânica. Ou seja, quanto menos gradagem eu conseguir, ou aração, ou subsolagem. (...). Então eu colho a cana, eu desseco a cana e venho plantando. Então eu uso pouco equipamento de preparo, né? E somente na Meiosi que eu faço o preparo realmente para o plantador de amendoim fazer o plantio, porque aí não tem como."

\section{Produtor Intermediário / Grande}

"A gente deixou as grades de lado. Todos os técnicos dizem que é um mal necessário e que não tinha outra coisa para fazer. Hoje nós estamos usando destruidor de soqueira, que já elimina sphenophoris e 
outras pragas, $100 \%$, e a subsolagem, que tem pra fazer o complemento do preparo de solo." Produtor Intermediário / Grande

"A gente adota a tecnologia de ponta que existe hoje, que é o plantio direto, tá? Desseca e planta. Depois a gente trata a soja com inseticida e tal...Depois que tira a soja, vai plantar cana. Simplesmente faz a subsolagem e vai plantando cana. ” Produtor Integral / Grande

Um dos produtores Intermediários /Grandes optou por fazer uma rotação prolongada, visando uma melhoria da estrutura do solo ainda maior, além de diversificar o risco econômico com a produção de diferentes culturas.

"Fazemos rotação de cultura nessas áreas com soja, plantio direto, retiro a soja, faço milho safrinha, tiro milho, entro com Meisoi, e tem os parceiros que fazem amendoim nestas Meiosis da cana. São 17 meses com estas três culturas e mais 17 ou 18 meses com a cana, até ela dar o seu primeiro corte."

\section{Produtor Intermediário / Grande}

"A rotação também é importante para o solo porque você despragueja o solo de ervas daninhas, invasoras. Outro fato é que você melhora a estrutura do solo porque você normalmente faz a rotação com uma leguminosa. Por isso que nós fazemos uma rotação ainda maior para melhorar ainda mais para a cana. Compensa. Você ganha em mais cortes.” Produtor Intermediário / Grande

O quadro 5 resume as percepções levantadas na fase de Conservação e Preparo do Solo.

Quadro 5 - Levantamento das percepções dos produtores relacionadas à Conservação e Preparo do Solo

\begin{tabular}{|c|c|c|c|c|}
\hline Atividade & Percepções & $\begin{array}{l}\text { Pos./ } \\
\text { Neg. }\end{array}$ & $\begin{array}{c}\text { Produtores } \\
\text { Entrevistados }\end{array}$ & $\begin{array}{l}\text { Agentes do setor } \\
\text { envolvidos }\end{array}$ \\
\hline Sistematização & $\begin{array}{l}\text { Sistematização é fundamental para } \\
\text { otimizar as operações mecanizadas, } \\
\text { reduzindo manobras, gasto de } \\
\text { tempo e perdas de insumos e } \\
\text { matéria prima e erosão. }\end{array}$ & + & Todos & $\begin{array}{c}\text { Serviços e } \\
\text { Tecnologias de } \\
\text { Sistematização e } \\
\text { Agricultura de } \\
\text { Precisão } \\
\text { Usinas }\end{array}$ \\
\hline Sistematização & $\begin{array}{l}\text { A sistematização, aliada ao piloto } \\
\text { automático, reduz bastante as } \\
\text { perdas no plantio e na colheita. }\end{array}$ & + & Intermediário / Grande & $\begin{array}{c}\text { Serviços e } \\
\text { Tecnologias de } \\
\text { Sistematização e } \\
\text { Agricultura de } \\
\text { Precisão } \\
\text { Usinas }\end{array}$ \\
\hline $\begin{array}{l}\text { Correção do } \\
\text { Solo }\end{array}$ & $\begin{array}{l}\text { Possibilidade de ganhos com a } \\
\text { agricultura de precisão para fazer } \\
\text { correção do solo à taxa variável. }\end{array}$ & + & Intermediário / Grande & $\begin{array}{l}\text { Serviços e } \\
\text { Tecnologias de } \\
\text { Agricultura de } \\
\text { Precisão }\end{array}$ \\
\hline $\begin{array}{l}\text { Correção do } \\
\text { Solo }\end{array}$ & $\begin{array}{l}\text { Cota de torta de filtro e Vinhaça da } \\
\text { Usina ajuda na fertilização do solo. }\end{array}$ & + & $\begin{array}{l}\text { Intermediário/Grande } \\
\text { Integral/Grande }\end{array}$ & Usina \\
\hline
\end{tabular}




\begin{tabular}{|c|c|c|c|c|}
\hline Atividade & Percepções & $\begin{array}{l}\text { Pos./ } \\
\text { Neg. }\end{array}$ & $\begin{array}{l}\text { Produtores } \\
\text { Entrevistados }\end{array}$ & $\begin{array}{l}\text { Agentes do setor } \\
\text { envolvidos }\end{array}$ \\
\hline $\begin{array}{l}\text { Correção do } \\
\text { Solo }\end{array}$ & $\begin{array}{l}\text { Busca por boas práticas através da } \\
\text { internet. Está testando utilização de } \\
\text { esterco de galinha como } \\
\text { fertilizantes. }\end{array}$ & + & Intermediário/Pequeno & \\
\hline $\begin{array}{l}\text { Correção do } \\
\text { Solo }\end{array}$ & $\begin{array}{l}\text { Não recebimento de cota de torta de } \\
\text { filtro da Usina }\end{array}$ & - & $\begin{array}{l}\text { Intermediário / } \\
\text { Pequeno }\end{array}$ & Usina \\
\hline $\begin{array}{l}\text { Preparo do } \\
\quad \text { Solo }\end{array}$ & $\begin{array}{l}\text { Preparo reduzido, revolvendo o } \\
\text { mínimo possível, para evitar perdas } \\
\text { de matéria orgânica }\end{array}$ & + & Todos & \\
\hline $\begin{array}{l}\text { Preparo do } \\
\quad \text { Solo }\end{array}$ & $\begin{array}{c}\text { Rotação de culturas melhora a } \\
\text { estrutura do solo, fixa nitrogênio e } \\
\text { ajuda a reduzir pragas. }\end{array}$ & + & Todos & \\
\hline $\begin{array}{l}\text { Preparo do } \\
\quad \text { Solo }\end{array}$ & $\begin{array}{l}\text { Rotação de } 17 \text { meses com soja, } \\
\text { milho safrinha e amendoim, } \\
\text { melhora ainda mais as condições do } \\
\text { solo e diversifica as culturas, } \\
\text { reduzindo o risco. }\end{array}$ & + & Intermediário / Grande & \\
\hline $\begin{array}{l}\text { Preparo do } \\
\quad \text { Solo }\end{array}$ & $\begin{array}{l}\text { Quando não dá tempo de fazer a } \\
\text { rotação, por causa do atraso da } \\
\text { colheita, é necessário fazer o } \\
\text { preparo convencional. }\end{array}$ & - & Pequeno / Básico & Usina \\
\hline
\end{tabular}

Fonte: Elaborado pelo autor

\subsubsection{Plantio}

Com relação à etapa de plantio de cana, as tecnologias de equipamentos disponíveis no mercado para a realização das operações são os aspectos de maior insatisfação entre os produtores.

O produtor Integral / Grande, que realiza as operações de corte de mudas e plantio mecanizados, considera os equipamentos inadequados para as suas necessidades.

\footnotetext{
"Não, o plantio hoje, nós temos que melhorar muito as plantadoras de cana para amenizar custo de muda e não danificar tanto as mudas. Tanto a colhedora, quanto a plantadora. E eu meço lá as minhas perdas, a minha germinação. Eu tenho absoluta certeza, as falhas que na nossa cultura lá, ela é provocada pelos equipamentos que nós temos. Isso daí é identificado lá. Ao ponto que você vê o índice de plantio manual aí, para pequeno e médio produtor, tá voltando à tona." Produtor "Integral / Grande
}

Isso é o que eu tenho falado para os fabricantes: Invés de o produtor se enquadrar nas máquinas que vocês fabricam, vocês que tem que se enquadrar com as particularidades dos produtores. Tudo o que acontece, as máquinas não são culpadas. Quem é culpado é o produtor, em matéria de sistematização. E 
quem faz tudo certinho e vai lá fazer o índice de perda e tem perda. Quem é culpado? É Cristo?... É a engenharia deles, né? Eles têm que buscar um melhoramento na engenharia deles. " Produtor Integral / Grande

Segundo o produtor Integral / Grande, as atividades relacionadas ao corte da muda e ao plantio mecanizado são mais críticas do que a colheita mecanizada (CCT). No plantio mecanizado, a maior dificuldade está na operação de distribuição, que leva a um aumento do consumo de mudas. Outro ponto crítico para ele é que, como o tolete tem que ser cortado, há maior incidência de doenças nos pós plantio. O corte da muda também é um problema porque danifica a gema, o que leva à perdas de mudas..

“O plantio (mecanizado) é pior ainda (do que a colheita mecanizada). A questão do plantio mecanizado,
o problema é que quando você planta manual, a cana fica inteira, tem menos porta de entrada pra doença.
Quando você planta mecanizado, o toletinho é cortado. É mais na parte de distribuição propriamente
dito e na parte de pós plantio, de doença, né? Não é no corte não. O corte também danifica mais gema
do que o corte manual, né? Então vai ter problema da gema danificada no corte. O maior problema é
distribuição. É quantidade de muda, que gasta muito mais mudas, né? Gasta mais toneladas pra plantar.
E geralmente a qualidade do plantio é bem inferior ao plantio manual." Produtor Integral / Grande

O produtor Intermediário / Pequeno, que também está realizando as operações de corte e plantio mecanizados, atribui ao corte mecanizado a causa do aumento do consumo de mudas, além de propiciar o surgimento da podridão do abacaxi, que demanda um aumento no custo pelo consumo de produtos para estimular a brotação.

\footnotetext{
"A colhedora estraga bastante a olhadura da cana. No mercado são todas ruins. Para colher a muda o pirulito é de borracha, mesmo assim ainda estraga. (...). Isso aumenta pra caramba a quantidade de muda. Não é que não distribui bem. É que na hora que você corta, machuca muito a gema. Então, invés de jogar 20 gemas no metro, tem que jogar 30, 35 pra nascer o número ideal que a da planta convencional. Aumenta quase 10 toneladas por alqueire pra jogar. Se forma aquele bolo, né? Aí, as que tão em baixo já fermentam. Dá Podridão do Abacaxi. Aí aumenta o custo. Tem que colocar o negócio para agilizar o nascimento, tem que colocar enraizador. Tem que aumentar os produtos." Produtor Intermediário / Pequeno
}

Os dois produtores Intermediários / Grandes realizam as operações de corte e plantio manuais. Eles argumentam que o corte mecanizado danifica muito a gema, gerando perdas, e a distribuidora não realiza uma distribuição linear.

\footnotetext{
"Mas o grande problema no plantio mecanizado é a colheita da muda e a plantadora. A colhedora de muda danifica muito o tolete, se perde muito. Não existem kits que você fala: esse é 100\%. O melhorzinho talvez seja $60 \%$ e danifica a muda. Por isso, você tem que jogar um monte de muda. Aí, depois você joga
} 
na distribuidora e você não consegue ter uma distribuição linear perfeita. Isso aí é impossível. Você aumenta o tolete na fazenda, começa a engastalhar lá. Porque quando você quer melhorar a qualidade da colheita, você aumenta o tamanho do tolete. Aumenta o tamanho do tolete, chega lá na plantadora, que não é plantadora, e começa a enrolar tudo lá. Então você tem que diminuir o tolete. Esse é um problema sério. Não tem. ” Produtor Intermediário / Grande

"É que aí, como você tem que preservar muito a gema da cana. E como essa cana de Meisoi é geralmente uma cana de 6 a 7 meses, é uma cana jovem. A gema é muito sensível. Qualquer coisa que bate nela, você já danifica. Então tem todo esse cuidado. E uma colhedora, quando ela colhe, você tem pancadas, você tem danos físicos. Eu até fiz uma distribuidora de muda lá, manual, que daria até pra melhorar aquilo. Mas ainda é manual a melhor forma pra gente.". Produtor Intermediário / Grande

Com relação à operação manual, um dos produtores Intermediários / Grandes considera a mão de obra mal preparada para realizar a distribuição de mudas.

\footnotetext{
"Faço distribuição das mudas manual. Essa é uma dificuldade. Apesar de ser uma atividade simples, as pessoas são menos instruídas. Poderia ter um trabalho, não sei se a associação, ou uma empresa poderia qualificar a mão de obra. Chama aí alguns empreiteiros aí que tem, e vamos dar um treinamento para este pessoal. Vamos explicar como funciona uma MEIOSI, vamos explicar quais são os cuidados, como é que tem que ser feito, por que que joga assim, tem que ser pé com ponta. Acho que aí é um gargalo." Produtor Intermediário / Grande
}

O produtor Básico / Pequeno começou a terceirizar recentemente a atividade de plantio para empreiteiro. Até então, quem realizava a atividade era a usina. O seu maior receio nesta atividade é a questão das adequações à legislação.

"Eu fiz um plantio com empreiteiro. Então você fecha um pacote. Ele colhe, transporta e planta. Antes era a usina que fazia pra mim. Aí era bem mais tranquilo, entendeu? Porque a usina é 100\% é legalizada, né? São muito fiscalizadas. Então eu sempre trabalhei com a usina. Depois a usina resolveu não plantar mais. Foi onde eu usei o empreiteiro pela primeira vez. No meu caso, de dois anos pra cá. Eu não tive problema, porque eu sempre procurei exigir. A própria certificação, ela te exige isso, né? Mas a gente fica sabendo aí, um lugar ou outro aí.” Produtor Intermediário / Grande

O quadro 6 resume as percepções levantadas na fase de Plantio 
Quadro 6 - Levantamento das percepções dos produtores relacionadas ao Plantio

\begin{tabular}{|c|c|c|c|c|}
\hline Atividade & Percepções & $\begin{array}{l}\text { Pos./ } \\
\text { Neg. }\end{array}$ & Produtores Entrevistados & $\begin{array}{l}\text { Agentes do } \\
\text { setor } \\
\text { envolvidos }\end{array}$ \\
\hline $\begin{array}{l}\text { Colheita e } \\
\text { Plantio } \\
\text { Mecanizado }\end{array}$ & $\begin{array}{l}\text { As colhedoras existentes, mesmo com os } \\
\text { kits para plantio mecanizado, danificam } \\
\text { muito a gema e se perde muito. Tem que } \\
\text { jogar fora e assim consome mais mudas. }\end{array}$ & - & $\begin{array}{l}\text { Intermediários/Grandes } \\
\text { Intermediário/Pequeno } \\
\text { Integral/Grande }\end{array}$ & $\begin{array}{l}\text { Fabricantes de } \\
\text { Equipamentos }\end{array}$ \\
\hline $\begin{array}{l}\text { Colheita e } \\
\text { Plantio } \\
\text { Mecanizado }\end{array}$ & $\begin{array}{l}\text { A necessidade de cortar o tolete para a } \\
\text { realização do plantio mecanizado se } \\
\text { torna uma porta de entrada para doenças. }\end{array}$ & - & Integral/Grande & $\begin{array}{l}\text { Fabricantes de } \\
\text { Equipamentos }\end{array}$ \\
\hline $\begin{array}{l}\text { Colheita e } \\
\text { Plantio } \\
\text { Mecanizado }\end{array}$ & $\begin{array}{c}\text { A operação de distribuição de mudas no } \\
\text { sulco não é homogênea e aumenta o } \\
\text { consumo. }\end{array}$ & - & $\begin{array}{c}\text { Intermediário/Grande } \\
\text { Integral/Grande }\end{array}$ & $\begin{array}{l}\text { Fabricantes de } \\
\text { Equipamentos }\end{array}$ \\
\hline $\begin{array}{l}\text { Colheita e } \\
\text { Plantio } \\
\text { Mecanizado }\end{array}$ & $\begin{array}{l}\text { O excesso de mudas no sulco propicia a } \\
\text { ocorrência da podridão do abacaxi, o que } \\
\text { demanda maior consumo de produtos } \\
\text { químicos e aumento do custo. }\end{array}$ & - & Intermediário/Pequeno & $\begin{array}{l}\text { Fabricantes de } \\
\text { Equipamentos }\end{array}$ \\
\hline $\begin{array}{l}\text { Distribuição } \\
\text { manual das } \\
\text { mudas }\end{array}$ & $\begin{array}{l}\text { Mão de obra é menos instruída e mal } \\
\text { preparada para fazer a distribuição de } \\
\text { muda, principalmente, considerando os } \\
\text { cuidados relacionados à Meiosi. }\end{array}$ & - & Intermediário/Grande & \\
\hline $\begin{array}{c}\text { Corte e } \\
\text { Plantio } \\
\text { Manual } \\
\text { Terceirizado }\end{array}$ & $\begin{array}{l}\text { Com a transferência do serviço de } \\
\text { plantio terceirizado da usina para } \\
\text { empreiteiros, o produtor se sente mais } \\
\text { inseguro quanto às adequações à } \\
\text { legislação. }\end{array}$ & - & Básico/Pequeno & Empreiteiro \\
\hline
\end{tabular}

Fonte: Elaborado pelo autor

\subsubsection{Tratos Culturais}

Com relação aos tratos culturais, os produtores relatam que com o fim das queimadas aumentou a incidência de ervas daninhas e pragas e o custo cresceu. O produtor Intermediário / Grande relata que as pragas são as maiores dificuldades. Até aprender a manejar, se perde e se gasta mais.

\footnotetext{
"Depois que começou a fazer a cana crua, acho que deu uma modificação na parte fisiológica do solo e mudou, tanto as ervas, né? Antigamente, na época do fogo, as ervas daninhas eram mais as gramíneas, né? Folha fina. Com a cobertura da palha, hoje mudou, nós temos folhas largas, que atrapalham muito mais a operação da colheita lá na frente. Então mudou, e muito." Produtor Intermediário / Grande
} 
“No bolso foi lá pra cima. (...). Quando a praga é nova, até você aprender como manejar, como combater, você acaba perdendo alguma coisa. Depois você faz o manejo, que aí o manejo você vai ter mais segurança." Produtor Intermediário / Grande

\begin{abstract}
“Antigamente ele (o meu pai) não tinha muita diversidade de variedade de materiais de cana, qualidade em adubação, herbicidas, inseticidas, também não tinha doença. Outra época, tinha queimada e acho que isso também ajuda um pouco. Prejudica uma coisa e melhora outra. Mas ele tinha uma produtividade superior à que nós temos hoje." Produtor Intermediário / Grande
\end{abstract}

No entanto, a maioria dos produtores se mostra satisfeito com as tecnologias que vem sendo desenvolvidas para a realização dos tratos culturais.

\begin{abstract}
"Os tratos culturais, eu acho que é a fase da cana que nós não estamos mal servidos não. Em termos de aplicação de herbicida, inseticida e até fungicida, a gente tá usando. Os equipamentos são muito bons." Produtor Intermediário / Grande
\end{abstract}

\begin{abstract}
"Sobre os tratos culturais a gente tem equipamento suficiente para tratar da cana. É tranquilo. A gente tem bons produtos. Um dos maiores problemas é a parte operacional mesmo... Mais é mais interno, né? A parte aplicação, as vezes tem problema de não ficar uma boa aplicação, as vezes por causa de chuva, por causa de clima, entendeu? Agora, os produtos, tem bastante produto com solução para os problemas, alguns com custo maior ou menor. E controle de pragas e doenças, e ervas daninhas a gente não tem tanta dificuldade não.” Produtor Integral / Grande
\end{abstract}

O produtor Básico / Pequeno utiliza o serviço de manejo integrado de pragas da cana, prestado pela associação. Ele está satisfeito com o serviço pois recebe orientação para fazer uso racional de inseticidas.

\footnotetext{
"Aí a gente tem um serviço prestado pela associação: inspeção de praga. Eles prestam esse serviço no plantio, na colheita e nos tratos. É um trabalho muito bom da associação. Eles fazem a inspeção de praga e me dá o número. Tem uma porcentagem que não tem perigo. (...). Então o inseticida é feito com a necessidade." Produtor Básico / Pequeno
}

O produtor Intermediário / Pequeno conta com o apoio dos técnicos da cooperativa para avaliar as ervas daninhas e escolher os herbicidas.

“Agrônomos das cooperativas ajudam a escolher os herbicidas. Depende do mato. Vêm, dão uma olhada,
fazem um levantamento. Ó, tem que aplicar isso, isso e isso." Produtor Intermediário / Pequeno

Os produtores Intermediários / Grandes utilizam o serviço de manejo integrado de pragas para a soja, prestado pela cooperativa. 
"O pessoal da cooperativa tá fazendo um trabalho muito bom com soja. Armam armadilha, avaliam pragas, criaram grupo legal no whatsapp com estas informações de todos produtores." Produtor Intermediário / Grande

"MIP da Soja é um espetáculo! Aí vou te falar: no passado e retrasado eu não comprei um litro de inseticida por causa do MIP. " Produtor Intermediário / Grande

Dois produtores citaram o serviço de aferição e regulagem de equipamentos utilizados durante os tratos culturais.

"Eles vêm regular tanto o destruidor de soqueira, que você precisa por causa do sphenoferus, bomba, os tanques de pulverização. Eles que dão assistência pra gente. " Produtor Intermediário / Pequeno

"Eles fazem toda a aferição, então você tem os comandos, o corpo de cada comando, de cada sessão de barra, então eles fazem uma aferição de todo o equipamento. Ó não tá legal, precisa trocar alguma coisa. Então eles dão um selo na bomba, como se a bomba estivesse certificada. Isso é legal sim, já fiz umas 34 vezes. ” Produtor Intermediário / Grande

Um dos produtores grandes está utilizando um mapeamento aéreo de pragas junto à uma das cooperativas, através de drones, em uma das suas áreas com alta infestação de pragas.

\footnotetext{
"Agora nós estamos entrando num levantamento através de drone. Também estamos buscando ajuda junto à Cooperativa para fazer um levantamento através do drone. Aí o que este mapeamento vai nos oferecer, nós vamos implantar.” Produtor Integral / Grande
}

Ouro aspecto destacado pelos grandes produtores foram os experimentos com insumos que as empresas realizam em suas propriedades. Eles demonstraram gostar de participar pelo fato de poderem inovar e aprender com os técnicos.

\footnotetext{
"Teve um monte de empresa que nos procurou para fazer experimento de soja. época de plantio de cana, chove empresa para fazer experimento de herbicida, inseticida, estas coisas. Alguns melhoram a produtividade, outros não. Todo pioneirismo tem um custo, ou para o bem ou para o mal. Mas a gente sempre prezou isto, inovação." Produtor Integral / Grande

"Os fornecedores são parceiros. A gente tem, o pessoal faz experimentos. Chegou a ficar lá uns oito ou dez anos. A gente aprendeu muito com eles e eles com a gente." Produtor Intermediário / Grande

O quadro 7 resume as percepções levantadas na fase de tratos culturais.
} 
Quadro 7 - Levantamento das percepções dos produtores relacionadas aos Tratos Culturais

\begin{tabular}{|c|c|c|c|c|}
\hline Atividade & Percepções & $\begin{array}{l}\text { Pos./ } \\
\text { Neg. }\end{array}$ & $\begin{array}{l}\text { Produtores } \\
\text { Entrevistados }\end{array}$ & $\begin{array}{l}\text { Agentes do } \\
\quad \text { setor } \\
\text { envolvidos }\end{array}$ \\
\hline Tratos Culturais & $\begin{array}{c}\text { Com o fim das queimadas, } \\
\text { aumentou a incidência de ervas } \\
\text { daninhas e pragas, o que elevou as } \\
\text { perdas e os custos. }\end{array}$ & - & $\begin{array}{c}\text { Intermediários/Grandes } \\
\text { Integral/Grande }\end{array}$ & Governo \\
\hline Tratos Culturais & $\begin{array}{l}\text { O mercado oferece bons produtos } \\
\text { e equipamentos para fazer os } \\
\text { tratos culturais }\end{array}$ & + & $\begin{array}{l}\text { Intermediários/Grandes } \\
\text { Integral/Grande }\end{array}$ & $\begin{array}{l}\text { Fornecedores } \\
\text { de } \\
\text { equipamentos } \\
\text { e de insumos }\end{array}$ \\
\hline Tratos Culturais & $\begin{array}{l}\text { Serviço de manejo integrado de } \\
\text { pragas na cana. Uso racional de } \\
\text { inseticidas. }\end{array}$ & + & Báscio/Pequeno & Associação \\
\hline Tratos Culturais & $\begin{array}{l}\text { Apoio técnico da cooperativa para } \\
\text { avaliar as ervas daninhas e } \\
\text { recomendar herbicidas }\end{array}$ & + & Báscio/Pequeno & Associação \\
\hline Tratos Culturais & $\begin{array}{l}\text { Serviço de manejo integrado de } \\
\text { soja }\end{array}$ & + & Intermediários/Grandes & Cooperativa \\
\hline Tratos Culturais & $\begin{array}{c}\text { Mapeamento de pragas e controle } \\
\text { junto à cooperativa, através de } \\
\text { drones. }\end{array}$ & + & Integral/Grande & $\begin{array}{c}\text { Cooperativas } \\
\text { Fornecedores } \\
\text { de AP }\end{array}$ \\
\hline Tratos Culturais & $\begin{array}{l}\text { Experimentos realizados por } \\
\text { fabricantes de insumos nas } \\
\text { propriedades, o que leva à } \\
\text { inovação e absorção de } \\
\text { conhecimento. }\end{array}$ & + & $\begin{array}{c}\text { Integral/Grande } \\
\text { Intermediário/Grande }\end{array}$ & $\begin{array}{l}\text { Empresas } \\
\text { Fornecedoras } \\
\text { de Insumos }\end{array}$ \\
\hline
\end{tabular}

Fonte: Elaborado pelo autor

\subsubsection{Colheita, Carregamento e Transporte}

O custo do CCT foi apontado por um dos produtores como o mais representativo entre as operações.

“O nosso maior custo fica no CCT, depois nas máquinas. Então qual é o caminho? Produzir muito para diluir o CCT, para que você tenha ali uma receita e consiga sobreviver.” Produtor Intermediário /

\section{Grande}

No entanto, os produtores relatam que tem maior poder de barganha do que em outras regiões do Brasil, conseguindo negociar subsídios no preço do serviço com a usina.

“Na nossa região o custo de CCT ainda é subsidiado. Se não fosse, aí para de produzir. Você consegue ter um poderzinho de barganha. Você consegue negociar com o volume.” Produtor Intermediário /

Grande 
“Ah, o custo representa muito, né? Os contratos são individuais, entendeu? Às vezes você consegue um subsídio no CCT, então isso vai variar muito a percentagem. É negociação. Cada um discute como acha melhor. Claro que um grande produtor vai conseguir algo melhor. Mas a gente que é menor também consegue alguma coisa. Nem todas as usinas faz isso também, viu? Hoje eu tenho um subsídio no contrato. " Produtor Pequeno / Básico

O produtor Integral / Grande, que tem estrutura própria para realizar o corte e o carregamento da cana, relata que consegue obter uma redução de custo ao realizar a operação. O alto investimento e a complexidade da operação compensam pois o seu custo é inferior ao preço cobrado pela usina.

"Fazer o CCT, igual nós fazemos, é uma coisa de reduzir custo. Reduz bem o custo, sabe. (...). Produzimos cana com custo menor do que a usina. Então é uma coisa que temos usado aqui. (...). Só que aí envolve muita gente, uma equipe grande, um operacional, né? E um grande investimento na estrutura de máquina." Produtor Integral / Grande

A qualidade da colheita é um ponto bastante sensível para a maioria dos produtores. $\mathrm{O}$ produtor Integral / Grande, apesar de considerar a alta tecnologia das máquinas, reconhece que o processo mecanizado leva a maiores perdas. A compactação do solo é o principal ponto destacado por ele, o que gera perdas de produtividade nos cortes futuros.

\footnotetext{
"Uma colheita mecanizada, mas sempre vão ter pontos de melhoria, pontos de perdas, né. Máquina, compactação do solo. As máquinas são de esteira, então tem problema de compactação de solo muito grande, que acarreta perdas de produtividade pro próximo anos. Mas em geral elas têm uma tecnologia muito alta, mas gera uma perda. Sempre tá gerando uma perda na produção, né." Produtor Integral / Grande
}

Ele pontua também fatores relacionados a falhas de operação, relacionadas à velocidade e ao sincronismo do transbordo e colhedora.

"Muitas vezes é questão de operador também, velocidade de máquina e sincronismo de transbordo e
colhedora, mas as perdas aí. As nossas perdas têm sido de média pra baixo, segundo os parâmetros que
a gente tem. Mas a colheita mecanizada, sempre vai ocorrer perdas sim. Não tem como." Produtor Integral / Grande

Os produtores que terceirizam o CCT para a usina, consideram o serviço de baixa qualidade e atribuem grande parte das perdas ao descuido das equipes de colheita da usina, descumprimento dos procedimentos, o que acaba gerando desperdício de matéria prima e danos à plantação. 
“A qualidade da colheita caiu muito. E o que ocorre? Somando isso (má qualidade da colheita) com a questão clima nos últimos anos, períodos prolongados de estiagem, altas temperaturas, vem atrapalhando muito. Primeiro a produtividade e segundo a longevidade do canavial. Nós somos obrigados a reformar antes e consequentemente você tem um dispêndio muito grande do investimento na reforma. Eles colhem, não têm uma boa qualidade eles cruzam, sulcam, arrancam soqueira, onde as máquinas pisam ali, eles não acompanham." Produtor Intermediário / Grande

"Colheita de cana é uma correria. Eles não querem que a usina fique parada. Aí começa a aumentar a velocidade da colhedora, vem aí tudo aquela desordem lá que desperdiça matéria prima, certo?"

\section{Produtor Intermediário / Grande}

“A gente é muito rígido. A gente pega muito no pé. Quando a usina tá colhendo, eu faço algum levantamento, pede sempre pra Associação tá visitando aí, semanalmente na época da colheita e as perdas são baixas. ” Produtor Intermediário / Grande

"Eles entram, a gente entra junto. Nós acompanhamos perda, velocidade de máquina. A gente tem o catálogo das máquinas, então a gente marca $50 \mathrm{~m}$ e fica cronometrando. Se passar a velocidade, a gente controla. No máximo 4,5, se tem faquinha que tá mastigando a soqueira da cana, o toco. Tem gente que ainda não entendeu que aquele toquinho é a cana do ano seguinte. Se você regular a máquina, vai deixar retinho assim. Então tem que deixar no mínimo 2-3 dedos porque aquilo ali é certeza de que você vai ter cana na safra futura. Tem que ficar em cima. Isso é lei. Se você não tomar conta do que é teu, a usina não toma não. ” Produtor Intermediário / Pequeno

Um dos produtores foi exceção. Ele se mostrou satisfeito com o serviço prestado pela usina, destacando o preparo do pessoal. Ele atribui a variabilidade na qualidade da colheita a diferenças de "colheitabilidade" das variedades e ao próprio processo mecanizado.

“As perdas tá dentro do normal. A única coisa é fiscalizar para ver se tá do jeito que a gente acordou. E tá acontecendo. As perdas tá dentro do normal. Não existe colheita mecânica sem perda. Eu vou contrariar alguns. Tem muita gente insatisfeita. Enfim, você tem que ser coerente. Por que aqui perdeu e por que aqui não perdeu? Você conhece a sua fazenda. Você sabe a diferença de variedades, da colheitabilidade. Não tem máquina que faz milagre. Eu vejo a usina (nome oculto) diferente das outras. O diferencial é o treinamento do pessoal. Eu tô satisfeito com a qualidade do serviço que eles prestam."

\section{Produtor Intermediário / Grande}

Os produtores mencionaram também o serviço da associação para avaliar a qualidade da colheita.

\footnotetext{
"Mas temos também um serviço da associação na colheita. Você solicita e eles vem ai para ver se a perda tá dentro do padrão, se tá colhendo bem, se tá deixando cana pra trás. Começou a colher, trabalhou um dia, eu ligo. Eles vêm aí, prestam o serviço, me dá o relatório. Fala ó, fica tranquilo que tá colhendo ou ó tá tendo um pouquinho mais de perda naquela área. Aí você pode ir lá e conversar. Vê o solo se não
} 
danificou, se arrancou raiz, se não pisoteou, se tá deixando cana pra trás. (...). porque veja bem, se eles estragarem, você tem os relatórios na mão. Você consegue depois ser ressarcido, se você se sentir prejudicado.” Produtor Básico / Pequeno

“A gente é muito rígido. A gente pega muito no pé. Quando a usina tá colhendo, eu faço algum levantamento, pede sempre pra associação tá visitando aí, semanalmente na época da colheita."

\section{Produtor Intermediário / Grande}

O quadro 8 resume as percepções levantadas na fase do CCT.

Quadro 8 - Levantamento das percepções dos produtores relacionadas ao CCT

\begin{tabular}{|c|c|c|c|c|}
\hline Atividade & Percepções & $\begin{array}{c}\text { Pos./ } \\
\text { Neg. }\end{array}$ & $\begin{array}{c}\text { Produtores } \\
\text { Entrevistados }\end{array}$ & $\begin{array}{c}\text { Agentes do setor } \\
\text { envolvidos }\end{array}$ \\
\hline CCT & $\begin{array}{c}\text { O custo de CCT é o mais } \\
\text { representativo entre as etapas } \\
\text { produtivas. }\end{array}$ & - & Todos & $\begin{array}{c}\text { Fornecedores de } \\
\text { Infraestrutura } \\
\text { Usinas }\end{array}$ \\
\hline CCT & Subsídio no custo na região & + & Todos & Usinas \\
\hline CCT & $\begin{array}{c}\text { Custo do CCT próprio é inferior } \\
\text { ao do serviço prestado pela usina. }\end{array}$ & + & Integral/Grande & $\begin{array}{c}\text { Associação } \\
\text { Produtores } \\
\text { Associados }\end{array}$ \\
\hline CCT & $\begin{array}{c}\text { Hoje vale mais a pena prestar } \\
\text { serviço de colheita do que } \\
\text { fornecer cana. }\end{array}$ & + & Integral/Grande & $\begin{array}{c}\text { Associação } \\
\text { Produtores } \\
\text { Associados }\end{array}$ \\
\hline CCT & $\begin{array}{c}\text { Baixa qualidade da colheita da } \\
\text { usina. "Tem que ficar em cima." }\end{array}$ & - & $\begin{array}{c}\text { Intermediários/Grandes } \\
\text { Intermediário/Pequeno } \\
\text { Básico/Pequeno }\end{array}$ & $\begin{array}{c}\text { Usina } \\
\text { Associação }\end{array}$ \\
\hline CCT & $\begin{array}{c}\text { Insatisfação com a tecnologia de } \\
\text { equipamentos de colheita }\end{array}$ & - & Integral/Grande & $\begin{array}{c}\text { Fabricantes de } \\
\text { Equipamentos }\end{array}$ \\
\hline CCT & $\begin{array}{c}\text { Serviço de avaliação de perdas da } \\
\text { associação }\end{array}$ & + & $\begin{array}{c}\text { Produtores } \\
\text { Intermediários e Básico }\end{array}$ & \begin{tabular}{c} 
Associação \\
\hline
\end{tabular} \\
\hline
\end{tabular}

Fonte: Elaborado pelo autor

\subsubsection{Comercialização}

\subsubsection{Contratos de Fornecimento}

Todos os produtores têm contrato de fornecimento com a usina. Com exceção do produtor integral, cujo contrato de fornecimento de cana é assinado via associação. Os demais têm contratos assinados individualmente com a usina.

"100\% do contrato de fornecimento de cana é originado dentro da associação. A associação que faz o contrato com o produtor e protocola na usina." Produtor Integral / Grande 
Os produtores consideram importante manter um relacionamento de longo prazo com as usinas, garantindo segurança de fornecimento e credibilidade no mercado.

“Comigo aqui nós não temos este problema (de descumprimento do acordo que ocorre com os outros produtores). É que a gente faz muitos anos que está na mesma usina. Nós nunca saímos. Nós estamos lá desde 1976, na mesma usina. Quer dizer que você tem, o pessoal fala que é privilégio. Meu pai é o terceiro fornecedor da usina por tempo de fornecimento.” Produtor Intermediário / Pequeno

"Spot a gente não faz. Tem que valer a pena uma boa parceria com a usina. Mas tem hora que coça pra fazer. Porque poderia receber bem mais. Porém você faz isso uma, duas vezes... e depois? É muito imediatista.” Produtor Intermediário / Grande

"Veja bem, quando eu venho aqui numa cooperativa, eu venho aqui comprar um insumo. Um dos questionamentos na atualização cadastral aqui é "Pra que usina você entrega?" Eles já sabem que são usinas estruturadas, consistentes, com seu financeiro organizado. Então eles têm uma segurança de que vendendo pra mim, eles vão receber.” Produtor Intermediário / Grande

Os produtores grandes conseguem negociar algumas vantagens com a usina.

"Tenho algumas negociações um pouco diferentes do CONSECANA, mas é muito particular no nosso caso. Mas isso foi um acordo que nós temos há muitos anos de fidelidade.” Produtor Intermediário / Grande

O produtor Integral / Grande relata o movimento das indústrias ao conceder benefícios a grandes fornecedores para garantir o volume de produção.

“As unidades industriais, para resolver seus problemas, começaram a buscar seus interesses econômicos junto aos grandes produtores e foi ajustando ao preço da matéria-prima, estabelecendo um ágio junto a estes produtores. Entendeu? Consecana $+x$. Foi dando uma tratativa caso a caso, certo? Pra contemplar economicamente cada produtor de cana desta natureza. Começou com estes produtores de grande escala. Só que o perfil dos produtores de cana do estado de SP é, em torno 75\%, são médios e pequenos. Então, a maioria dos produtores não foram contemplados. ” Produtor Integral / Grande

Além do CCT, citado no capítulo anterior, os produtores grandes declararam que a época da colheita é um fator importante a ser acordado. Como descrito no capítulo 6.3.1.2, os produtores preferem negociar realização da colheita precocemente.

"A minha cana é colhida entre abril e maio, e o restante, até agosto. Eu tenho um acordo com a Usina que não pode passar de agosto. ” Produtor Intermediário / Grande

A declaração do Pequeno Produtor Básico também evidencia que ele gostaria de negociar a realização da colheita com maior antecedência. Como também foi relatado no 
capítulo 6.3.1.2, este produtor tem limitações no planejamento de suas atividades durante a reforma pelo fato de realizar a colheita tardiamente.

"Você senta, assina um contrato, as partes cumprem, então você não tem muito assim que... não vejo um relacionamento desgastado. É lógico que cada um puxa a sardinha pro seu lado. Se eu pudesse colher a cana mais cedo, colher a da gente primeiro..." Produtor Pequeno / Básico

O Produtor Intermediário / Pequeno também demonstra que teria maior poder de barganha se pudesse entregar um volume maior para a usina.

"Se os primos tivessem todos aí, estaríamos hoje com 780 alqueires. Você tinha um poder de fogo dentro da usina, que você falava ó, eu quero deste jeito.” Produtor Intermediário / Pequeno

\subsubsection{ATR Relativo}

Com relação ao ATR Relativo, existe uma insatisfação com o modelo de avaliação da qualidade da cana, já que, na visão do produtor, ele pode estar sendo remunerado por um índice de ATR inferior ao performado. No entanto, considerando a necessidade de abastecimento das usinas ao longo de todos os meses do ano, eles demonstram compreender a necessidade de um modelo para buscar um equilíbrio.

\footnotetext{
"ATR relativo também não me atende. O meu ATR tem que ser, quando colho muito cedo, tem que ser melhor que o da usina, porque, se não, eu perco. Tem alguns momentos que eu ganho mais com o ATR relativo. Só que para eu ganhar, eu ganho mais do que o meu real deu. Então alguém vai perder. Por isso que o relativo é bem relativo mesmo. Esse relativo é uma briga.” Produtor Intermediário / Grande

“Antigamente eles pagavam o ATR nosso. Eu achava melhor. Mas só que aí começou os problemas. Por exemplo, você colhe em abril e maio, a tua ATR é baixa. Que nem, a minha que cortava tarde era melhor. Eu tinha ATR alta. Só que aquele que fornecia primeiro, ele se via em desvantagem. Então, no meu caso, era melhor o outro, porque a minha cana sempre deu um ATR alto, por causa da época. ” Produtor Básico / Pequeno
}

Um dos produtores faz uma ponderação, avaliando que o ATR relativo estimula também a eficiência.

"O ATR relativo estimula também quem for mais eficiente...Olha se a gente produzir um pouco mais, a gente ganha mais que a usina. Então tem isso também. Tem os dois lados então tem isso também." Produtor Intermediário / Grande

Já a percepção do produtor intermediário pequeno é de que o ATR relativo não remunera a busca pela eficiência. 
"Hoje não vale mais nada o período da colheita. Com o ATR relativo você acaba perdendo para aqueles que não tão nem aí para a coisa. O nosso ATR gira em torno de 145 a 152, e no fim nós recebemos uma média de 136, 137. ” Produtor Intermediário / Grande

O produtor Integral entrega cana todos os meses para a usina e é remunerado pelo ATR realizado, não pelo ATR relativo. Pelo fato de sua colheita ser linear, não considera que tem diferença a remuneração por um ou por outro modelo.

“Eu não vejo, em matéria de apurar o kg de ATR por tonelada, eu não vejo diferença nenhuma pra quem
entrega cana linearmente. Mas só que a maioria dos produtores, não é o nosso caso. A maioria é entrega
concentrada. Por isso que existe um grau de insatisfação com o ATR relativo.” Produtor Integral / Grande

\subsubsection{Preço do ATR}

Dentre todos os aspectos levantados, o preço do ATR foi o de maior insatisfação. Todos os produtores apontaram a dificuldade de sustentar economicamente o negócio com o atual patamar de preço.

\footnotetext{
"Há uns três ou quatro anos, quando e eu faço o nosso custo de produção e o nosso custo de oportunidade, quanto o meu patrimônio está me remunerando, quando eu lanço, pego o tanto de terra que nós temos e faço o cálculo sobre uma tonelagem, sobre o preço do ATR, tal, tal. Nós estamos no negativo. Já é o quarto ano que estamos trabalhando no negativo.” Produtor Intermediário / Grande

"Eu tô plantando grãos e, se isso continuar indo bem, e está, eu vou aumentar grãos. Consequentemente você diminui a oferta de cana e quem sabe não melhora o preço." Produtor Intermediário / Grande

"Você sabe, o plantio de soja, aqui o sócio tá querendo reverter o nosso faturamento. Invés de cana, passar tudo pra soja, pela questão financeira. ” Produtor Integral / Grande

"Precisa melhorar, se não, não aguenta não. Eu acho assim, chegou num limite. Mas hoje é o que eu consigo aí manter. Eu acho que nós estamos aí numa situação bem delicada. Aí você tem outras opções. Você pode arrendar, falar: eu não aguento mais tocar. Pode arrendar tanto pra usina, quanto para um terceiro. Não é a minha vontade, entendeu. Eu gosto de tocar aqui." Produtor Básico / Pequeno
}

Todos os produtores entrevistados adotam o modelo Consecana para precificação do ATR. Alguns produtores enxergam uma necessidade de revisão da fórmula do Consecana, prevista em regulamento, mas consideram que as negociações entre as partes que representam os produtores (Orplana) e as usinas (Unica) não vêm alcançando êxito. 


\begin{abstract}
"Os primeiros cinco anos (do Consecna) foram muito bem. Só que dentro do regulamento, contempla uma revisão técnica, certo? Pra poder se adequar junto às inovações tecnológicas que vai se evoluindo junto ao setor produtivo. E justo nesta primeira revisão, já se criou o impasse. Em razão de que, em razão dos interesses, né? Porque as duas partes têm seus interesses e aí os interesses foram conflitantes. Até hoje nós não nos ajustamos. É onde que o setor da cadeia produtiva dos produtores de cana veio se enfraquecendo a cada ano, em razão de resultados. ” Produtor Integral / Grande
\end{abstract}

"A fórmula do Consecana requer uma revisão porque, quando criou o Consecana já estava nas regras prevista uma revisão. Vários trabalhos foram feitos por empresas conceituadas e chegou a resultados. Transferência de renda é complicado você conseguir. E não conseguiu fazer até hoje. Não sei se consegue." Produtor Intermediário / Grande

"Só que hoje o problema tá lá no Preço do ATR. É o Consecana. São as revisões, que não acontece nada. Única, Orplana, ficam brigando, brigando e não acontece nada. ” Produtor Intermediário / Grande

“Estão fazendo um estudo, estão fazendo um estudo, mas tá duro de acabar este estudo. Todo ano é a mesma coisa.” Produtor Intermediário / Pequeno

O produtor Pequeno / Básico vincula as questão do preço mais a um problema de mercado.

"A dificuldade nossa de uns anos pra cá tá aí. Baixou muito a matéria prima nossa hoje. Ela tá sendo vendida a um preço aquém do que precisava. Por quê? Existe muito estoque de açúcar no mundo. A oferta é grande, né? Então o preço cai. E tem as regiões na Índia, na Indonésia. Aqueles lugares estão produzindo bastante também. São lugares que não produziam muito. Isso aí tá impactando aqui." Produtor Básico / Pequeno

Com relação à fórmula do Consecana, dentre os aspectos que os produtores consideram que devem ser revisados está o reconhecimento da eficiência, agregando valor ao preço.

“Não somos reconhecidos por isso (pela certificação). É uma matéria prima diferenciada. As usinas recebem por isso. Nós sabemos que as usinas recebem pelo produto final, só que ela não repassa para os seus produtores. Isso aí nós estamos diariamente conversando com as indústrias para." Produtor Integral / Grande

"Só que o objetivo maior disso daí (da certificação) seria você agregar valor, né? E não vai acontecer. Quem tem não tá agregando valor.” Produtor Intermediário / Grande

"Por que qual que é a ideia da certificação? Você receber por isso também. Se tem uma mercadoria certificada, ela tem certo valor também. Hoje ainda não somo remunerados por isso. Tá sendo feito um trabalho para que a gente receba por isso, para que sirva de incentivo para os outros também. Para que 
entre mais gente no processo. Agora a expectativa é que nem eu falo. Tem que melhorar o preço da matéria-prima. ” Produtor Básico / Pequeno

"O que a gente tem é que, eu acho assim. A hora que tiver algum problema, a certificação vai ser mais um argumento pra você mostrar. Olha, eu cumpro com tudo, por isso eu sou certificado. Mas em termos de valores, eu não vejo que ninguém tá tirando proveito disso ainda não. E pelo que eu vejo as usinas não estão dispostas a pagar por isso.” Produtor Intermediário / Grande

Um dos produtores apontou para a questão de transferência de ineficiências industriais para o preço do ATR. “Consecana não precifica tão bem. As revisões, de 4 em 4 anos, não mexem em nada. Já foi detectado
que teve ineficiência da unidade industrial de 6\%, não sei em qual processo lá, e isso é problema dela.
Não é do fornecedor. O fornecedor não pode pagar por isso. Que ela melhore o processo.” Produtor
Intermediário / Grande

A regionalização do preço é outro aspecto levantado por dois produtores:

"O reconhecimento desta natureza, porque a produção de cana e a fabricação de açúcar e etanol é extremamente complexa, certo? isto daí varia de região para região. então o que eu defendo, eu defendo um CONSECANA região. A gente mantém um CONCENA mãe e embasado nisto daí, fortalecendo as associações de classe, que é através da associação que nós vamos desenvolver um CONSECANA regional, contemplando todas as particularidades de cada região." Produtor Integral / Grande

"E eu não acho muito justo você receber pela média do estado. pq tem aquelas usinas que estão em uma situação financeira ruim. Então eles tem que vender o almoço pra pagar a janta. Tem aquelas que estão em situação melhor, que armazenam para vender na época melhor. E a gente não participa deste negócio. É o que a gente queria. receber pelo mix da Usina que a gente entrega. Aí já seria um CONSECANA Regionalizado." Produtor Intermediário / Grande

O produtor Integral / Grande acrescenta ainda que o risco assumido por produtores verticalizados ao investir em infraestrutura de plantio e colheita também deveria ser reconhecido.

"Então, dentro do aspecto de você ter uma certificação, de você ter uma colhedora, você cortar, pôr a cana na usina, precisa ter um mérito diferenciado dos outros produtores. O produtor independente que assume este risco, ameniza o risco para a usina. esse risco não é reconhecido.” Produtor Integral / Grande

“Hoje quem tá ganhando dinheiro junto ao setor sucroenergético é que arrenda terra. O arrendatário está sendo mais bem remunerado, que é o que tem menos risco na cadeia produtiva. Então, acho que o negócio tá distorcido. Tá na contramão.” Produtor Integral / Grande 
Já o produtor Intermediário / Pequeno demonstrou insatisfação com a inexistência de um compartilhamento dos subprodutos no preço.

"Até o valor do ATR também é falho, faz mais de 15 anos que está no 0,50-0,60, nunca sai disso. Só que quando eles fizeram o ATR, eles computaram energia elétrica, torta de filtro, bagaço, vinhaça. Eles computam tudo, só que o fornecedor não recebe nada, né? Se é produto nosso, nós temos que ter uma participação, né? Receber ou incluir no preço da cana, uma porcentagem de tantos porcento a mais. Se a gente tivesse parte do subproduto dava uma grana." Produtor Intermediário / Pequeno

O quadro 9 resume as percepções levantadas durante a fase de Comercialização.

Quadro 9 - Levantamento das percepções dos produtores relacionadas à Comercialização.

\begin{tabular}{|c|c|c|c|c|}
\hline Atividade & Percepções & $\begin{array}{l}\text { Pos. } \\
\text { /Neg }\end{array}$ & $\begin{array}{c}\text { Produtores } \\
\text { Entrevistados }\end{array}$ & $\begin{array}{c}\text { Agentes do } \\
\text { setor envolvidos }\end{array}$ \\
\hline $\begin{array}{l}\text { Contratos de } \\
\text { Fornecimento }\end{array}$ & $\begin{array}{l}\text { Importância de estabelecer } \\
\text { acordos através de contratos e } \\
\text { relacionamentos de longo prazo } \\
\text { com as usinas sólidas, } \\
\text { garantindo segurança e } \\
\text { credibilidade no mercado. }\end{array}$ & + & Todos & $\begin{array}{l}\text { Produtores } \\
\text { Usinas }\end{array}$ \\
\hline $\begin{array}{l}\text { Contratos de } \\
\text { Fornecimento }\end{array}$ & $\begin{array}{l}\text { Negociação de subsídio de } \\
\text { preço na operação de CCT }\end{array}$ & + & $\begin{array}{c}\text { Intermediários/Grandes } \\
\text { Intermediário/Pequeno } \\
\text { Básico/Pequeno }\end{array}$ & $\begin{array}{c}\text { Usinas } \\
\text { Produtores }\end{array}$ \\
\hline $\begin{array}{l}\text { Contratos de } \\
\text { Fornecimento }\end{array}$ & $\begin{array}{l}\text { Maiores vantagens financeiras e } \\
\text { operacionais são concedidas a } \\
\text { produtores de grande porte (ex. } \\
\text { modelo de remuneração, época } \\
\text { da colheita, cotas de } \\
\text { subprodutos) }\end{array}$ & + & Grandes Produtores & $\begin{array}{c}\text { Usinas } \\
\text { Produtores }\end{array}$ \\
\hline $\begin{array}{c}\text { Modelo } \\
\text { CONSECANA }\end{array}$ & $\begin{array}{l}\text { Não há satisfação com o ATR } \\
\text { relativo. No entanto, há também } \\
\text { a compreensão de que foi a } \\
\text { forma encontrada para atender à } \\
\text { necessidade de fornecimento } \\
\text { linear para a indústria. }\end{array}$ & - & Todos & $\begin{array}{c}\text { Produtores } \\
\text { Usinas } \\
\text { CONSECANA }\end{array}$ \\
\hline $\begin{array}{c}\text { Modelo } \\
\text { CONSECANA }\end{array}$ & $\begin{array}{l}\text { Insatisfação elevada com o } \\
\text { modelo de precificação do } \\
\text { ATR. Necessidade de adequar a } \\
\text { fórmula às mudanças do setor, } \\
\text { reconhecendo eficiência e } \\
\text { compartilhando valor. }\end{array}$ & - & Todos & $\begin{array}{c}\text { Produtores } \\
\text { Usinas } \\
\text { CONSECANA }\end{array}$ \\
\hline
\end{tabular}

Fonte: Elaborado pelo autor 


\subsubsection{Planejamento e Gestão de Resultados}

O produtor Integral / Grande, devido à sua estrutura e organização gerencial, foi o único que respondeu realizar um processo de planejamento estruturado, envolvendo as diversas áreas da empresa.

"Cada um aí senta aqui faz seu planejamento de insumos, planejamento de manutenção, planejamento de tudo, tá certo? E aí, claro, tem sempre uma distorção, pra cima ou pra baixo.” Produtor Integral / Grande

São realizadas projeções de resultados através de indicadores de custo e produtividade para cada talhão ao longo dos cortes, com o auxílio de um software de gestão.

“O software é uma planilha financeira onde nós inserimos informações sobre todas as áreas de produção, cada talhão e cada corte, do primeiro ao sétimo, quais são as produtividades, quais são os custos em cada etapa. A partir daí são realizadas estimativas, projeções de números de cortes e dos valores para os próximos cortes. Projeções do que ainda está em baixo da terra." Produtor Integral / Grande

Um dos produtores Intermediário / Grande relatou analisar os custos por etapa de produção, indicadores de produtividade e rentabilidade do negócio.

\footnotetext{
“Eu sei os custos das operações na planilha do excel, custo hora/máquina, só atualizo com preço de combustível, lubrificante, valor do salário, e eu tenho um custo. Então eu sei o custo fechado de cada operação e aí só lanço os insumos em relação a valor, dose. Mas eu faço por ano, final do ano, quando dá mais tempo." Produtor Intermediário / Grande
}

\footnotetext{
"Quando eu faço o nosso custo de produção e o nosso custo de oportunidade, quanto o meu patrimônio está me remunerando. Quando eu lanço, pego o tanto de terra que nós temos e faço o cálculo sobre uma tonelagem, sobre o preço do ATR, tal, tal...” Produtor Intermediário / Grande
}

O outro Produtores Intermediário / Grande relatou comparar os custos de um ano para o outro sem fazer de planilhas de controle.

\footnotetext{
“Não uso planilha. É sempre real versus produto. Por exemplo, no ano passado gastei x para fazer o plantio de soja, do plantio à colheita. Esse ano $x+$. Você transforma em dólar pra você ter um melhor parâmetro diferente para não ser real, né? $R \$ /$ ha ou $R \$ /$ ton $R \$ /$ saco, tanto faz. Mas na realidade, no fim é o que sobra no bolso." Produtor Intermediário / Grande
}

Os produtores pequenos fazem uso da ferramenta caderno de campo, que foi um serviço de orientação prestado pela Associação sobre a gestão dos processos, a partir do acompanhamento da produtividade e dos custos por etapa de rodução. Um deles, 
adicionalmente, utiliza também uma planilha em excel, que a filha atualiza, para acompanhar seus indicadores.

"A gente faz. Vai fazendo um comparativo com os anos anteriores: área colhida, produção, custo, faz comparativo entre custo dos insumos todo ano. Faz comparativo de preço de óleo diesel. Aí a gente já faz por hora pra saber quanto que custa por ano cada tipo de aplicação. Durante todo o período, a gente vai fazendo. Usamos o caderno que a Associação deu pra gente. Então, a gente vai acompanhando e vai marcando. ” Produtor Intermediário / Pequeno

"Anoto tudo no caderno. Tá vendo, ó: variedade, o quanto colheu. Quer ver, ó. Receita da propriedade. Aqui é tudo o que eu usei na cana. Tem tudo os produtos que usei, o que eu apliquei. Isso aqui foi junto com a certificação. Então hoje eu tenho aqui um controle dos meus custos." Produtor Básico / Pequeno

O caderno de campo possibilitou ao Produtor Básico / Pequeno uma visão melhor de seu negócio e uma possibilidade de fazer gestão em cima dos indicadores.

"Primeiro você ia no banco, se tinha dinheiro sobrando, tava indo bem, se tava faltando, tava indo mal. Hoje não, hoje você pode detalhar. Aqui um exemplo, ó tô gastando muito aqui no óleo diesel. O que que eu posso fazer para diminuir? Ó ano passado eu gastei mais aqui, esse ano eu consegui reduzir. Então ele te o detalhe, então em matéria de gestão, você tem uma visão melhor." Produtor Básico / Pequeno

O Quadro 10 resume as percepções levantadas durante o processo de Planejamento e Gestão de Resultados.

Quadro 10 - Levantamento das percepções dos produtores relacionadas ao Planejamento e Gestão de Resultados

\begin{tabular}{|c|c|c|c|c|}
\hline Atividade & Percepções & $\begin{array}{l}\text { Pos. } \\
\text { /Neg }\end{array}$ & $\begin{array}{l}\text { Produtores } \\
\text { Entrevistados }\end{array}$ & $\begin{array}{l}\text { Agentes do } \\
\text { setor } \\
\text { envolvidos }\end{array}$ \\
\hline $\begin{array}{l}\text { Planejamento } \\
\text { e Gestão }\end{array}$ & $\begin{array}{c}\text { Planejamento estruturado envolvendo } \\
\text { diversas áreas da empresa }\end{array}$ & + & Integral/Grande & \\
\hline $\begin{array}{l}\text { Planejamento } \\
\text { e Gestão }\end{array}$ & $\begin{array}{l}\text { Projeções técnicas e financeiras do } \\
\text { canavial por talhão ao longo dos cortes e } \\
\text { acompanhamento dos resultados }\end{array}$ & + & Integral/Grande & $\begin{array}{l}\text { Fornecedor } \\
\text { de Software } \\
\text { de Gestão }\end{array}$ \\
\hline $\begin{array}{l}\text { Planejamento } \\
\text { e Gestão }\end{array}$ & $\begin{array}{l}\text { Acompanhamento da produtividade, } \\
\text { custos por etapa, lucro e remuneração do } \\
\text { capital em Excel }\end{array}$ & + & $\begin{array}{l}\text { Intermediário/Grande } \\
\text { Intermediário/Pequeno }\end{array}$ & $\begin{array}{l}\text { PECEGE } \\
\text { Cursos de } \\
\text { Gestão }\end{array}$ \\
\hline $\begin{array}{l}\text { Planejamento } \\
\text { e Gestão }\end{array}$ & $\begin{array}{c}\text { Serviço de orientação prestado pela } \\
\text { associação aos produtores sobre a gestão } \\
\text { dos processos, através de indicadores, } \\
\text { fazendo uso da ferramenta Caderno de } \\
\text { Campo. }\end{array}$ & + & $\begin{array}{l}\text { Intermediário/Pequeno } \\
\text { Básico/Pequeno }\end{array}$ & Associação \\
\hline
\end{tabular}

Fonte: Elaborado pelo autor 


\subsubsection{Adequação à Legislação}

Problemas trabalhistas foram destacados pela maioria dos produtores. Um dos produtores declarou estar migração para operações mecanizadas, mesmo com qualidade inferior, para minimizar problemas trabalhistas.

“Agora o problema maior é mão de obra, né? Nem acho a nossa mão de obra cara. Eu acho ruim. Muito problema trabalhista. Por isso que a gente torce para que esta nova CLT venha aí para dar mais segurança.” Produtor Intermediário / Grande

"Legislação trabalhista é pro trabalhador. Patrão tá sempre errado, né? E a gente tem problema trabalhista? Sim. É problema. E a legislação ambiental é pior. Pior porque tem alguns aí, juízes aí, promotores, eles ainda querem fazer a lei, né?’ Produtor Intermediário / Grande

“Funcionário hoje em dia, nós só temos um e estamos mantendo tudo dentro pra não ter problema mais. Mão de obra também a gente já não usa mais porque é quase tudo máquina, né? Estamos usando o mínimo possível de mão de obra pra não ter problema. Já fazem quatro plantios que estamos fazendo mecanizado por causa de mão de obra. Isso aumenta pra caramba a quantidade de muda." Produtor Intermediário / Pequeno

O pequeno produtor não contrata mão de obra, pois consegue realizar as atividades que não são terceirizadas juntamente com o filho.

"Não contrato mão de obra. Sou eu e eu o meu filho. Nós temos todos os treinamentos pra isso." Produtor Básico / Pequeno

Na parte ambiental, um dos produtores vê o radicalismo dos fiscais como um dos entraves, que dificulta, a realização das atividades de adequação à legislação.

\footnotetext{
“O problema é o radicalismo, tanto do produtor que não quer fazer nada, reflorestar, se adequar, quanto dos fiscais. Alguns fiscais mandam fazer ações que vão até prejudicar o próprio ecossistema. $O$ ecossistema se desenvolve muito por causa dos passarinhos que levam as sementes. Quando fiscal manda capinar ou aplicar roundup para o mato pode tirar este tipo de vegetação que a própria natureza propiciou naturalmente.” Produtor Intermediário / Grande
}

Todos os produtores entrevistados estão realizando as adequações que a legislação exige, tanto trabalhistas, quanto ambientais. A associação dá suporte jurídico na realização das adequações.

“A associação dá suporte bom pra gente nesta parte jurídica socioambiental. Toda a orientação a gente recorre a eles, mesmo porque, como é um tema muito comum pra gente, eles sempre estão atualizados. 
Quanto a isso, eu tenho tranquilidade em buscar lá. Eu prefiro a Associação do qualquer advogado da cidade. Pode até ser especialista daquela área, mas a Associação, ela é mais efetiva." Produtor Intermediário / Grande

“Tem o próprio departamento jurídico da associação que orienta como a gente deve agir na propriedade para ficar isento das penalidades possíveis, né? em função de algum acidente, né? Porque hoje a maior parte dos fogos são criminosos, né? O problema é qdo acontece o crime e vc ser responsabilizado por ele. que não é, na realizada não é. nos dão uma cartilha que eles desenvolveram lá pra gente seguir lá, na associação pra gente não ser penalizado. caso isso acontecer. ” Produtor Intermediário / Grande

"Hoje esse trabalho vem sendo feito com a associação. Então, por exemplo, surgiu o CAR, o PRA, ato declaratório da água, a Socicana deu todo o suporte pra nós. então eu tô legalizado. eu fiz toda a papelada se exigia." Produtor Básico / Pequeno

“Com relação à parte ambiental, a nossa é todinha legalizada. Nós tivemos as reuniões com a advogada lá. e foi feito, foi planejado, nós ficamos esperando, precisamos fazer o CAR, precisamos fazer o PRA. Ela orientou tudo o que a gente tinha que fazer. Depois teve que fazer outra vez, segunda etapa do PRA, é negócio do xxx, pessoal que usa muita água precisa fazer outorga de água, fazer medição de consumo. Quer dizer que esta parte aí, ela foi nos orientado. Foi bem tranquilo.” Produtor Intermediário / Pequeno

O produtor Integral / Grande conta com um departamento jurídica dentro da sua estrutura organizacional para realizar as adequações socioambientais.

\footnotetext{
"Isso aí tá dentro. Não pode fazer nada fora da legislação. Somos auditados duas vezes por ano pela Bonsucro. Temos o departamento jurídico contratado e temos a empresa de prestação de serviço da segurança do trabalho. ” Produtor Integral / Grande
}

Todos os produtores entrevistados estão participando de programas de qualificação promovido pela associação para obtenção de certificação socioambiental. O produtor Integral / Grande já está no quarto ano de certificação. Um dos produtores pequenos obteve a certificação RSB (Roundtable on Sustainable Biomaterials), voltada para pequenos produtores. Os demais estão em fase de conclusão.

"Então, você tendo a certificação, já vai é uma certificação de que você tá cumprindo todas as etapas, tanto trabalhista, ambiental. Então o certificado é importante, independente de agregar ou não. se agregar melhor, se não agregar, ele tb é muito importante.” Produtor Intermediário / Grande

"Somos referência para os programas. Estamos no quarto ano de certificação. Trabalhista zero." Produtor Integral / Grande 
"Nós estamos fazendo a certificação de cana. inclusive a gente tava bem adiantado já, mas teve um grupo que se destacou, sabe? Mais era tempo, pra você correr atrás de coisinhas simples. Então, a gente resolveu sair pra não segurar o grupo todo.” Produtor Intermediário / Grande

$\mathrm{O}$ quadro 11 resume as percepções levantadas pelos produtores relacionadas às Adequações à Legislação.

Quadro 11 - Levantamento das percepções dos produtores relacionadas às Adequações à Legislação

\begin{tabular}{|c|c|c|c|c|}
\hline Atividade & Percepções & $\begin{array}{l}\text { Pos./ } \\
\text { Neg. }\end{array}$ & $\begin{array}{c}\text { Produtores } \\
\text { Entrevistados }\end{array}$ & $\begin{array}{l}\text { Agentes do } \\
\text { setor } \\
\text { envolvidos }\end{array}$ \\
\hline $\begin{array}{l}\text { Legislação } \\
\text { Trabalhista }\end{array}$ & Problemas Trabalhistas. & - & Todos & $\begin{array}{l}\text { Governo } \\
\text { (CLT) }\end{array}$ \\
\hline $\begin{array}{l}\text { Legislação } \\
\text { Trabalhista }\end{array}$ & $\begin{array}{c}\text { Migração para operações mecanizadas, } \\
\text { mesmo com qualidade inferior para } \\
\text { minimizar contratação por problemas } \\
\text { trabalhistas. }\end{array}$ & - & Intermediário/Pequeno & $\begin{array}{l}\text { Governo } \\
\text { (CLT) }\end{array}$ \\
\hline $\begin{array}{l}\text { Adequação à } \\
\text { Legislação } \\
\text { Ambiental }\end{array}$ & Radicalismos dos Fiscais & - & Intermediário/ Grande & $\begin{array}{l}\text { Governo } \\
\text { (Fiscais) }\end{array}$ \\
\hline $\begin{array}{l}\text { Adequação à } \\
\text { Legislação } \\
\text { Ambiental e } \\
\text { Trabalhista }\end{array}$ & $\begin{array}{c}\text { Suporte jurídico e técnico da associação } \\
\text { para a realização das adequações } \\
\text { socioambientais }\end{array}$ & + & Todos & Associação \\
\hline Certificações & $\begin{array}{l}\text { Programas de qualificação promovidos } \\
\text { pela associação apoia o produtor no } \\
\text { processo de certificação socioambiental. }\end{array}$ & + & Todos & $\begin{array}{l}\text { Associação, } \\
\text { Órgãos de } \\
\text { Certificação }\end{array}$ \\
\hline
\end{tabular}

Fonte: Elaborado pelo autor

\subsubsection{Governança e Sucessão}

Um dos aspectos de maior preocupação dos pequenos produtores é a continuidade do negócio. Ou seja, evitar uma divisão da propriedade, perdendo escala e perdendo poder de barganha nas negociações.

“Eu sou a quarta geração. Os que tão chegando agora são a quinta geração. Espero que eles deem continuidade no que está dando certo, né? (...). Eu falei pra minha mãe, ela quer passar a parte dela para os netos. Ó, só pode ser vendido entre herdeiros. Pra ferrar eles. Ninguém vai ter dinheiro pra comprar um do outro...é porque você mantém eles na terra. Mesmo que, ó eu não quero, eu arrendo pra você e você continua. Se os primos tivessem todos aí, estaríamos hoje com 780 alqueires. (..).Você tinha um poder de fogo dentro da usina, que você falava ó, eu quero deste jeito." Produtor Intermediário /

\section{Pequeno}


"Se amanhã, faltar um dos mais velhos, como é que fica? E se um de nós quer vender? E aí? Você perde força, você diminui. Vai sobrar um vasinho de terra para cada um. ” Produtor Intermediário / Grande

"Eu trago o meu filho para ir aprendendo, mas ele tá estudando uma outra área. Tá estudando engenharia mecatrônica. Mas eu falo pra ele também. Ele tem que seguir isso aqui. É a sucessão, né? A família diminuiu, né? Então tá cada vez mais difícil. Eu só tenho um filho. Meu bisavô comprou, que tinha 16. Aí meu avô foi comprando dos irmãos, os irmãos foi comprando em outro lugar. Aí passou para o meu pai e os tios. E hoje tá com nós. Tem lá a minha prima que mora lá e o meu primo que mora aqui. Tamo tocando. Só que vai diminuindo e vai ficando cada vez mais difícil, né.” Produtor Básico / Pequeno

"Vai ter que vir alguém de fora e dizer como tem que fazer, as regras são essas. a regra atende todo mundo? Acho que não vai atender todo mundo. Não sei, talvez vai ter que xxxxx pra crescer junto, porque quando você separa, quando você divide, você aumenta custo, né? Mas enfim, é melhor separar do que brigar." Produtor Intermediário / Grande

A inexistência de regras, funções, responsabilidades bem definidas é outro ponto sensível para os produtores. No entanto, consideram este ponto delicado e difícil de conduzir.

"Essa questão de governança e sucessão nós vamos sofrer um pouco. Tudo que tem de despesas, paga, e
o que tem de receita divide. Não faz separando por área. É pra não dar problema, quem trabalha, mais,
quem trabalha menos. Mas é um ponto que pra mim é bem delicado. A gente precisava sentar e definir." Produtor Intermediário / Grande

"Mas eu acho que lá na frente, eu acho que vai precisar de uma consultoria. Eu acho que nós vamos precisar pra pôr regras para as pessoas. Esse ponto aí que eu acho que a gente vai precisar, porque se você chegar lá na fazenda e falar assim: ó você merece ganhar mais, você merece ganhar menos. Tem que vir alguém de fora e dizer. Porque se eu, de casa, falar vai dar atrito, né?" Produtor Intermediário / Grande

"Quem administra sou eu. O meu filho e o sobrinho participam. Falou tá falado. (Eles têm funções definidas?) Não, conforme vai chegando o serviço, vai fazendo. Vai chegar mais um sobrinho, que tá acabando o colegial. Aquele ali, eu tenho certeza que, ele e o meu filho, são mesmo erradicados no negócio."Produtor Intermediário / Pequeno

Já o produtor Integral/ Grande, juntamente com o irmão e os filhos, constituiu um condomínio, através do qual implantaram um modelo de governança e sucessão e compartilham uma estrutura administrativa, que conta com três gerências, além de assessoria jurídica, serviço de recursos humanos, segurança do trabalho e auditoria contábil.

\footnotetext{
"Nós sentamos aqui e determinamos esse organograma aqui. Foi se aperfeiçoando... Ao ponto que eu preciso prestar conta para o meu diretor financeiro. Meus filhos, a mesma coisa. Meu sócio, a mesma coisa. E auditado pela auditoria externa.” Produtor Integral / Grande
} 
“A gente achou melhor fazer isso daí para tocar a nossa gestão com imparcialidade. Eu falando uma coisa, é uma coisa. O meu irmão falando, é igual. Agora vem um profissional falar pra nós o que a gente tem que fazer, é outra coisa. Facilita um monte de coisa na nossa governança." Produtor Integral / Grande

“A sucessão já tá praticamente concretizada. (...). Cada um tem sua participação no condomínio. A gente já começou o condomínio desde 1989. ” Produtor Integral / Grande

O quadro 12 resume as percepções relacionadas à Governança e Sucessão.

Quadro 12 - Levantamento das percepções dos produtores relacionadas à Governança e Sucessão

\begin{tabular}{|c|c|c|c|c|}
\hline \multirow{2}{*}{ Atividade } & Percepções & $\begin{array}{c}\text { Pos./ } \\
\text { Neg. }\end{array}$ & $\begin{array}{c}\text { Produtores } \\
\text { Entrevistados }\end{array}$ & $\begin{array}{c}\text { Agentes do } \\
\text { setor } \\
\text { envolvidos }\end{array}$ \\
\hline Sucessão & $\begin{array}{c}\text { Preocupação com a descontinuidade do } \\
\text { negócio ou com a divisão das terras, } \\
\text { perdendo escala e poder de barganha. }\end{array}$ & - & $\begin{array}{c}\text { Intermediários/Grande } \\
\text { Intermediário/Pequeno } \\
\text { Básico/ Pequeno }\end{array}$ & Consultorias \\
em
\end{tabular}

Fonte: Elaborada pelo Autor

\subsubsection{Atuação integrada entre produtores}

Alguns aspectos relacionados à atuação integrada entre produtores foram explorados na entrevista, como ações coletivas para obter melhores condições de compra, desenvolver operações de maneira conjunta para obter ganhos de escala, aumentar o poder de negociação com as usinas, troca de boas práticas entre produtores e ainda compartilhamento de serviços através das associações e das cooperativas.

Alguns produtores consideram que poderiam ter maiores economias no custo dos insumos se conseguissem realizar pool de compras.

“A cooperativa compra, mas não é bem também um grupo de produtores que se organiza. É a cooperativa que compra e oferece. Por exemplo, se eu quiser comprar agora, eu ligo e ele vai cotar pra mim. Não, Não. O ideal seria ter um pool de compra. Vamos supor, vou pegar aqui, cinco ou seis amigos e falar 
assim, vamos comprar hoje dez mil toneladas de adubo ou vamos comprar cem mil litros de produto. Aí seria um pool de compra. Tenho certeza que a gente ia comprar mais barato." Produtor Intermediário / Grande

Um dos produtores descreveu uma tentativa que não foi bem-sucedida de realizar um pool de compras.

\footnotetext{
"Nós começamos a fazer parte de um pool do sindicato, mas não deu resultado não. É aquilo que eu te falei, todo mundo quer ser o número um. Por que que fulano vai receber o adubo hoje e o meu vem só na semana que vem? É aquela coisinha que o ser humano tem chamada ego. Então, no fim, acabou não dando resultado as compras de adubo e veneno pra laranja. Infelizmente, mais uma coisa que precisou ser fechada." Produtor Intermediário / Pequeno
}

Outros produtores, consideram que, mesmo não obtendo ganhos de preço, através de pool de compras, a cooperativa contribui, melhorando as condições de compra, através de outras formas:

\footnotetext{
"Às vezes ela (a Cooperativa) não consegue fazer um pool de compra pra fazer a melhor compra, só que ela consegue, esse ano, correu até os cooperados pra avisar: "compra adubo que vai faltar." Estamos com problema de frete, greve. Tem alguns momentos que a cooperativa liga e orienta, ó vai subir o preço, compra que a tabela vai aumentar. Então assim, isso é uma forma de fazer uma compra bem-feita." Produtor Intermediário / Grande
}

Um dos produtores grandes acredita que seria uma oportunidade para otimizar a sua estrutura de equipamentos e funcionários através de uma plataforma de compartilhamento de equipamentos ou de serviços.

\footnotetext{
"Existe (a possibilidade de compartilhar equipamentos). Até uma das coisas legais. A gente teve uma ideia uma época de fazer um grupo. Por exemplo, eu tenho um trator com uma grade intermediaria de 28 dias, tal, tal, tal. Neste grupo, você coloca lá, disponível, custo tal. Aí eu sei que está disponível. Vamos supor, tá do meu lado e eu não sei. Falha na comunicação!’ Produtor Intermediário / Grande

"Dá para organizar se as atividades são realizadas na mesma época porque tem alguns momentos... Por exemplo, eu faço a safrinha de milho. eu tô com milho lá que ainda não chegou. Eu tô com uns funcionários parados. ” Produtor Intermediário / Grande
}

O outro produtor Intermediário / Grande não vê oportunidade de compartilhamento de equipamentos no seu porte. Quando questionado sobre oportunidades de compartilhamento, declarou: 
"Não, no meu tamanho não. Quando eu era pequeno eu acho que era interessante e bom. Não existe oportunidade de compartilhamento, porque todos querem realizar as atividades na mesma época." Produtor Intermediário / Grande

O produtor Intermediário / Pequeno descreveu uma tentativa de compartilhamento de equipamentos através do sindicato, que também não foi bem-sucedida.

"Já teve no sindicato em Taquaritinga, mas não deu certo. Porque, primeiro, na hora que eles devolvem
o implemento, devolvem quebrado e ninguém quebrou. Ninguém faz revisão e manutenção.” Produtor Intermediário / Pequeno

Sobre a possibilidade de desenvolver operações de maneira conjunta, o produtor Intermediário / Pequeno citou um exemplo de condomínio.

“Na Europa, os vizinhos se juntam, todos preparam a terra juntos. Plantam com a mesma plantadeira,
fazem uma sequência, vão acabando de arar aqui, já vão plantando, já acabou aqui, eles mesmos vão
passando o veneno. Infelizmente aqui todo mundo quer ser o primeiro.” Produtor Intermediário /
Pequeno

O produtor Integral / Grande considera o modelo de realização das atividades de plantio e colheita de forma conjunta pelos associados da sua associação, uma boa prática, na medida em que reduz os custos e torna o produtor menos dependente da usina, aumentando o seu poder de negociação via associação.

"Então, pra todos estes produtores aqui, esses 5 produtores de cana, dentro de uma governança de um planejamento, que colhem toda a cana dos produtores e plantam toda a cana dos produtores. E o risco das frentes não é nada da associação, é do produtor. Mas só que a associação ajudou eles. Esses caras aqui, são todos independentes. Os custos do CCT são melhores do que o da usina porque as frentes de trabalho aqui, nós temos uma tabela do estado de São Paulo. Nem da usina é. $100 \%$ do contrato de fornecimento de cana é originado dentro da associação. A associação que faz o contrato com o produtor e protocola na usina.” Produtor Integral / Grande

O produtor Intermediário Pequeno, acredita ser necessário maior união entre os produtores para aumentar o poder de negociação com a usina.

\footnotetext{
“Eu acho que tá faltando assim, o pessoal se unir para poder prevalecer a força também do agricultor. Porque o pessoal tá muito desunido nesta parte aí. Na negociação com a usina. Porque eles compram, fazem o contrato e o contrato vale pra você. É unilateral, não é bilateral. Eles te compram a cana e falam; “ó nós vamos tirar.” Quando? Aí só Deus sabe. ” Produtor Intermediário / Pequeno
} 
Com relação ao compartilhamento de informações, um dos produtores relatou que há um comportamento individualista entre os produtores. A participação em reuniões para discussão de temas em comum ocorre apenas quando existem problemas.

\footnotetext{
"O agricultor só troca informação, compartilha aí, quando a coisa tá muito ruim. quando a coisa tá boa parece que tá todo mundo cuidando da vida particular. A associação faz a parte dela. Faz bem feito, mas na maioria das reuniões que a gente tem lá, você não consegue encher a casa. Você enche a casa quando a cana não vale nada...Não vejo a classe unida para reivindicar e não vejo a classe unida assim, pra trocar informação." Produtor Intermediário / Grande
}

Alguns produtores descreveram práticas positivas para promover a troca de informação, através de programas promovidos pelas associações e cooperativas. O programa de melhoria de gestão em questões técnicas, de negócios e socioambientais, promovido pela associação, foi mencionado por proporcionar trocas entre os produtores.

\footnotetext{
Depois que formou o grupo Top cana, o pessoal parece que queficou mais cabeça aberta aqui. Começamos a ser mais vizinhos. Porque ali você tem que falar o que você tá fazendo, o que você fez. Então começaram a se abrir e, no fim, ficou mais fácil até de você conversar, né?" Produtor Intermediário / Pequeno
}

Um dos produtores citou uma boa prática da cooperativa, que são os núcleos de desenvolvimento.

O produtor grande relatou que a criação dos núcleos de desenvolvimento que tem o intuito de promover a participação dos cooperados em temas específicos, como por exemplo: insumos, tecnologia e inovação, formação de lideranças, mulher, etc

\footnotetext{
"Eles pegaram os núcleos e colocaram cooperados que tem mais afinidade melhor com aquele tipo de negócio. O que que é? Toda demanda, eles recebem via núcleo, numa reunião que eles fazem, nuтa reunião que é aberta pros núcleos, e aí as pessoas: "ó tõ precisando disso, isso não tá bom", tal, tal. Eles acatam isso daí. E não é só receber e levar o problema. Não, eles têm que receber o problema, discutir a solução, leva para diretoria e aí a diretoria vai ver se é viável, fazer um estudo pra ver se vale a pena fazer daquela forma, ou se tem outro jeito. E aí trazer este feedback pra eles. "Olha gente não dá pra fazer assim, mas assim a gente conseguiria." Então assim, ajudou muito esta comunicação." Produtor Intermediário / Grande
}

Quanto aos serviços prestados pelas associações e das cooperativas, é possível reunir aqui uma série de serviços relacionado às diferentes etapas do processo, que os produtores citaram ao longo das entrevistas, como por exemplo, a carta de Solos, a assistência técnica na escolha dos insumos por engenheiro agrônomos, o serviço de avaliação e controle de pragas, o 
serviço de avaliação de perdas, assessoria para adequação à legislação, programa de qualificação etc.

O quadro 13 resume as percepções relacionadas à Atuação Integrada entre Produtores.

Quadro 13 - Levantamento das percepções dos produtores relacionadas à Atuação Integrada entre Produtores

\begin{tabular}{|c|c|c|c|c|}
\hline Atividade & Percepções & $\begin{array}{l}\text { Pos./ } \\
\text { Neg. }\end{array}$ & $\begin{array}{c}\text { Produtores } \\
\text { Entrevistados }\end{array}$ & $\begin{array}{l}\text { Agentes do setor } \\
\text { envolvidos }\end{array}$ \\
\hline $\begin{array}{l}\text { Ações coletivas } \\
\text { para melhorar } \\
\text { condições de } \\
\text { compras }\end{array}$ & $\begin{array}{l}\text { Através das cooperativas obtém } \\
\text { melhores condições de compra } \\
\text { de insumos e financiamentos. }\end{array}$ & + & $\begin{array}{c}\text { Intermediário/Grande } \\
\text { Básico/Pequeno }\end{array}$ & Cooperativas \\
\hline $\begin{array}{l}\text { Ações coletivas } \\
\text { para melhorar } \\
\text { condições de } \\
\text { compras }\end{array}$ & $\begin{array}{l}\text { Pool de compras seria uma } \\
\text { oportunidade para obtenção de } \\
\text { descontos. }\end{array}$ & - & $\begin{array}{l}\text { Intermediário/Grande } \\
\text { Intermediário/Pequeno }\end{array}$ & - \\
\hline $\begin{array}{l}\text { Compartilhamento } \\
\text { de Estrutura e } \\
\text { Funcionários }\end{array}$ & $\begin{array}{l}\text { Poderia otimizar estrutura e } \\
\text { funcionário através de aplicativo } \\
\text { de compartilhamento de } \\
\text { equipamentos e serviços. }\end{array}$ & - & $\begin{array}{l}\text { Intermediário/Grande } \\
\text { Intermediário/Pequeno }\end{array}$ & $\begin{array}{l}\text { Plataformas de } \\
\text { compartilhamento } \\
\text { digitais }\end{array}$ \\
\hline $\begin{array}{l}\text { Compartilhamento } \\
\text { de Estrutura e } \\
\text { Funcionários }\end{array}$ & $\begin{array}{l}\text { Poderia otimizar estrutura e } \\
\text { funcionários através de } \\
\text { Condomínio para realização de } \\
\text { atividades em conjunto. }\end{array}$ & - & Intermediário/Pequeno & - \\
\hline $\begin{array}{l}\text { Realização de } \\
\text { operações } \\
\text { conjuntas }\end{array}$ & $\begin{array}{c}\text { Modelo de realização de } \\
\text { operações coletivas, viabilizado } \\
\text { pela associação. }\end{array}$ & + & Integral/Grande & $\begin{array}{c}\text { Associações } \\
\text { Usinas }\end{array}$ \\
\hline $\begin{array}{c}\text { Poder de } \\
\text { negociação com a } \\
\text { usina }\end{array}$ & $\begin{array}{l}\text { A união dos produtores daria } \\
\text { maior poder de negociação com } \\
\text { a usina }\end{array}$ & - & Intermediário/Pequeno & Usinas \\
\hline $\begin{array}{c}\text { Troca de } \\
\text { Informações e } \\
\text { boas práticas }\end{array}$ & $\begin{array}{l}\text { Comportamento individualista } \\
\text { dos produtores. Baixa } \\
\text { participação em reuniões } \\
\text { promovidas pelas associações e } \\
\text { cooperativas. }\end{array}$ & - & Intermediário/Grande & \\
\hline $\begin{array}{c}\text { Troca de } \\
\text { Informações e } \\
\text { boas práticas }\end{array}$ & $\begin{array}{c}\text { A troca de boas práticas } \\
\text { aumentou com o programa de } \\
\text { qualificação promovido pela } \\
\text { associação. }\end{array}$ & + & Intermediário/Pequeno & Associações \\
\hline $\begin{array}{l}\text { Busca conjunta de } \\
\text { melhorias para o } \\
\text { setor }\end{array}$ & $\begin{array}{l}\text { Núcleos de Desenvolvimento, } \\
\text { promovidos pelas cooperativas } \\
\text { promovem a participação dos } \\
\text { produtores para fortalecer o } \\
\text { setor. }\end{array}$ & + & Intermediário/Grande & Cooperativas \\
\hline $\begin{array}{l}\text { Serviços prestados } \\
\text { pelas associações } \\
\text { e cooperativas }\end{array}$ & $\begin{array}{l}\text { Diversos serviços técnicos das } \\
\text { associações e das cooperativas } \\
\text { foram citados durante diversas } \\
\text { etapas do processo. }\end{array}$ & + & Todos & $\begin{array}{l}\text { Associações } \\
\text { Cooperativas }\end{array}$ \\
\hline
\end{tabular}

Fonte: Elaborado pelo autor 


\section{CRIAÇÃO DAS PERSONAS}

Após a análise dos dados coletados, percebeu-se que, de fato, havia diferenças significativas entre as experiências vivenciadas pelos cinco produtores que participaram da pesquisa. Mapear apenas uma curva da experiência não seria possível. Por outro lado, mapear cinco experiências geraria um excesso de documentos, com informações redundantes, perdendo seu sentido de utilidade.

A técnica de construção de personas é recomendada para representar diferentes perfis para os quais se quer mostrar as experiências. (KALBACH, 2017; TRISCHLER; ZEHRER, 2012). Ao invés de trabalhar com dados demográficos para distinguir os segmentos, a técnica parte do entendimento de como as pessoas se comportam, quais são as suas frustrações, seus desejos e como utilizam os produtos e serviços estudados (LISBOA, 2019; KALBACH, 2017). Ao dar nomes fictícios para estas personas e criar uma narrativa sobre seus padrões de comportamento, a técnica possibilita um envolvimento maior das equipes que estão realizando um esforço para melhorar as experiências de seus clientes. A técnica fornece um modo fácil de referir-se a um segmento, chamando-o por um nome (KALBACH, 2017).

As experiências mapeadas para estas personas reúnem aspectos positivos e negativos relatados por um grupo de pessoas. Segundo Kalbach (2017), não existe um único cliente que vivencie todos os aspectos positivos e negativos identificados em um diagrama da experiência. Alguns são relatados por uma pessoa, outros relatados por outra pessoa do mesmo grupo.

É possível criar personas formais após a realização de uma pesquisa ampla e profunda do usuário, o que pode ser um esforço demorado. Mas também é possível criar personas "de suposição" ou personas "de provisão" até que a pesquisa avance com maior profundidade (KALBACH, 2017).

Seguindo estas recomendações e, pelo caráter exploratório deste estudo, optou-se por criar personas de forma preliminar, que em estudos futuros, a partir de uma base ampliada de pesquisa, poderão ser revisadas e definidas de forma mais assertiva.

Os insumos utilizados para construção das personas foram os dados coletados a partir das cinco entrevistas realizadas. Com o intuito de capturar características que podem distinguir diferenças de comportamento entre os entrevistados e agrupá-los, todos as percepções levantadas no capítulo anterior foram analisadas de forma comparativa, através do Quadro 14. 
Quadro 14 - Quadro comparativo sobre as percepções positivas e negativas levantados nas entrevistas

\begin{tabular}{|c|c|c|c|c|c|c|}
\hline Processo & Atividade & Integral / Grande & Intermediário/ Grande & $\begin{array}{c}\text { Intermediário/ } \\
\text { Grande }\end{array}$ & $\begin{array}{l}\text { Intermediário/ } \\
\text { Pequeno }\end{array}$ & Básico / Pequeno \\
\hline \multicolumn{2}{|c|}{ Objetivos de Negócio } & $\begin{array}{l}\text { Sustentabilidade do } \\
\text { Negócio e do Setor }\end{array}$ & Lucratividade & $\begin{array}{l}\text { Remuneração do } \\
\text { Negócio }\end{array}$ & Lucratividade & $\begin{array}{l}\text { Manutenção da } \\
\text { propriedade }\end{array}$ \\
\hline \multirow[t]{3}{*}{$\begin{array}{l}\text { Planejamento } \\
\text { Agrícola }\end{array}$} & $\begin{array}{l}\text { Vocação } \\
\text { técnica do } \\
\text { ambiente }\end{array}$ & + Carta de Solos & + Carta de Solos & + Carta de Solos & + Carta de Solos & + Carta de Solos \\
\hline & $\begin{array}{l}\text { Desenvolvime } \\
\text { nto de } \\
\text { variedades }\end{array}$ & $\begin{array}{l}\text { - Insatisfação com o } \\
\text { ritmo e custo das } \\
\text { pesquisas e } \\
\text { desenvolvimento } \\
\text { varietal. }\end{array}$ & $\begin{array}{l}\text { - Insatisfação com o } \\
\text { ritmo e custo das } \\
\text { pesquisas e } \\
\text { desenvolvimento } \\
\text { varietal. }\end{array}$ & $\begin{array}{l}\text { - Insatisfação com o } \\
\text { ritmo e custo das } \\
\text { pesquisas e } \\
\text { desenvolvimento } \\
\text { varietal. }\end{array}$ & - & - \\
\hline & $\begin{array}{l}\text { Escolha da } \\
\text { Época do } \\
\text { Plantio e da } \\
\text { Colheita }\end{array}$ & $\begin{array}{l}\text { + Entrega Linear para a } \\
\text { Usina. } \\
\text { + Planejamento } \\
\text { integrado realizado pela } \\
\text { associação. }\end{array}$ & $\begin{array}{l}\text { + Colheita Precoce. } \\
+ \text { Tem tempo para } \\
\text { realizar outras } \\
\text { atividades na reforma. }\end{array}$ & $\begin{array}{l}\text { + Colheita Precoce. } \\
+ \text { Época boa para a } \\
\text { brotação. Tempo para } \\
\text { realizar outras } \\
\text { atividades na reforma. }\end{array}$ & $\begin{array}{l}\text { Colheita Média } \\
\text { Precoce. } \\
\text { Sem atrasos. }\end{array}$ & $\begin{array}{l}\text { - Colheita Tardia. } \\
\text { - Atrasos na colheita. } \\
\text { Impactos na realização } \\
\text { de outras operaços. }\end{array}$ \\
\hline $\begin{array}{l}\text { Organização de } \\
\text { Recursos }\end{array}$ & $\begin{array}{l}\text { Dimensionam } \\
\text { ento da } \\
\text { Máquinas e } \\
\text { Equipamentos }\end{array}$ & $\begin{array}{l}\text { Possui toda estrutura Só } \\
\text { terceiriza o transporte. } \\
\text { + Otimiza estrutura } \\
\text { realizando a plantio e } \\
\text { colheita para outros } \\
\text { produtores. }\end{array}$ & $\begin{array}{l}\text { Possui quase toda a } \\
\text { estrutura, com exceção } \\
\text { do CCT. } \\
\text { Não vê oportunidades } \\
\text { para otimizar via } \\
\text { compartilhamento. }\end{array}$ & $\begin{array}{l}\text { Possui quase toda a } \\
\text { estrutura, com exceção } \\
\text { do CCT. } \\
\text { Vê oportunidades para } \\
\text { otimizar via } \\
\text { compartilhamento / } \\
\text { aplicativo. }\end{array}$ & $\begin{array}{l}\text { Possui quase toda a } \\
\text { estrutura, com exceção } \\
\text { do CCT. } \\
\text { Vê oportunidades para } \\
\text { otimizar via } \\
\text { compartilhamento / } \\
\text { condomínio. }\end{array}$ & $\begin{array}{l}\text { Possui estrutura para } \\
\text { realizar apenas os } \\
\text { Tratos Culturais. }\end{array}$ \\
\hline
\end{tabular}




\begin{tabular}{|c|c|c|c|c|c|c|}
\hline \multirow[t]{3}{*}{ Processo } & Atividade & Integral / Grande & Intermediário/ Grande & $\begin{array}{c}\text { Intermediário/ } \\
\text { Grande }\end{array}$ & $\begin{array}{l}\text { Intermediário/ } \\
\text { Pequeno }\end{array}$ & Básico / Pequeno \\
\hline & $\begin{array}{l}\text { Planejamento } \\
\text { e compra dos } \\
\text { Insumos }\end{array}$ & $\begin{array}{l}+ \text { A equipe interna } \\
\text { realiza o planejamento. }\end{array}$ & $\begin{array}{l}\text { + Assistência técnica e } \\
\text { condições de compra } \\
\text { das cooperativas. }\end{array}$ & $\begin{array}{l}\text { + Assistência técnica e } \\
\text { condições de compra } \\
\text { das cooperativas. }\end{array}$ & $\begin{array}{l}\text { + Assistência técnica e } \\
\text { condições de compra } \\
\text { das cooperativas. }\end{array}$ & $\begin{array}{l}\text { + Assistência técnica e } \\
\text { condiçôes de compra } \\
\text { das cooperativas. }\end{array}$ \\
\hline & $\begin{array}{l}\text { Levantamento } \\
\text { de Recursos } \\
\text { Financeiros }\end{array}$ & $\begin{array}{l}\text { - Ativo biológico pouco } \\
\text { valorizado como } \\
\text { garantia para concessão } \\
\text { de crédito. }\end{array}$ & $\begin{array}{l}\text { + Oferta de crédito } \\
\text { para quem tem } \\
\text { garantias. }\end{array}$ & $\begin{array}{l}\text { + Realiza a maior parte } \\
\text { das compras à vista. } \\
\text { + Juros mais atrativos } \\
\text { nas Cooperativas de } \\
\text { Crédito, porém exigem } \\
\text { maiores garantias. }\end{array}$ & $\begin{array}{l}\text { + Realiza 100\% das } \\
\text { compras à vista e } \\
\text { obtém melhores } \\
\text { negociações. }\end{array}$ & $\begin{array}{l}\text { - Na época da compra } \\
\text { de insumos ainda não } \\
\text { colheu. Precisa } \\
\text { financiar. } \\
\text { + Cooperativas de } \\
\text { Crédito tem condições } \\
\text { e juros mais acessíveis. }\end{array}$ \\
\hline \multirow[t]{2}{*}{$\begin{array}{l}\text { Produção de } \\
\text { Mudas }\end{array}$} & $\begin{array}{l}\text { Produção de } \\
\text { Mudas }\end{array}$ & $\begin{array}{l}\text { + Convencional. } \\
\text { MPBs ainda são caras e } \\
\text { a tecnologia de plantio } \\
\text { com baixa qualidade e } \\
\text { rendimento. }\end{array}$ & $\begin{array}{l}\text { + MPB / Sanidade das } \\
\text { mudas Redução custo / } \\
\text { de implantação. } \\
\text { - Tecnologia de plantio } \\
\text { de MPB com baixa } \\
\text { qualidade e rendimento }\end{array}$ & $\begin{array}{l}\text { + MPB / Sanidade das } \\
\text { mudas / Redução custo } \\
\text { de implantação; } \\
\text { + Equipamento de } \\
\text { plantio adaptada na } \\
\text { fazenda. }\end{array}$ & $\begin{array}{l}\text { + Convencional. } \\
\text { MPBs ainda são caras. }\end{array}$ & $\begin{array}{l}\text { + Convencional. } \\
\text { Ainda não avaliou a } \\
\text { possibilidade de } \\
\text { trabalhar com MPBs. }\end{array}$ \\
\hline & $\begin{array}{l}\text { Produção de } \\
\text { Mudas }\end{array}$ & $\begin{array}{l}+ \text { Cantosi } \\
\text { Meiosi não vale a pena } \\
\text { em grande escala. }\end{array}$ & $\begin{array}{l}\text { + Meiosi } \\
\text { Reduz custos. É mais } \\
\text { trabalhoso, mas } \\
\text { compensa. Reduz } \\
\text { custos. }\end{array}$ & $\begin{array}{l}\text { + Meiosi } \\
\text { Reduz custos. É mais } \\
\text { trabalhoso, mas } \\
\text { compensa. }\end{array}$ & $\begin{array}{l}+ \text { Cantosi } \\
\text { MEISOI é trabalhoso, } \\
\text { precisa fazer irrigação, } \\
\text { investimento alto em } \\
\text { piloto automático. }\end{array}$ & $\begin{array}{l}\text { - Cantosi } \\
\text { Gostaria de fazer } \\
\text { MEISOI para reduzir } \\
\text { custos de transporte. A } \\
\text { época da colheita } \\
\text { tardia o impossibilita. }\end{array}$ \\
\hline
\end{tabular}




\begin{tabular}{|c|c|c|c|c|c|c|}
\hline Processo & Atividade & Integral / Grande & Intermediário/ Grande & $\begin{array}{l}\text { Intermediário/ } \\
\text { Grande }\end{array}$ & $\begin{array}{l}\text { Intermediário/ } \\
\text { Pequeno }\end{array}$ & Básico / Pequeno \\
\hline \multirow[t]{5}{*}{ Preparo do Solo } & $\begin{array}{l}\text { Conservação } \\
\text { do Solo }\end{array}$ & $\begin{array}{l}\text { + Sistematização } \\
\text { Plantio e colheita com } \\
\text { piloto automático. } \\
\text { Grande redução de } \\
\text { perdas. }\end{array}$ & $\begin{array}{l}\text { + Sistematização com } \\
\text { orientação da usina } \\
\text { Áreas consideradas de } \\
\text { alto rendimento. }\end{array}$ & $\begin{array}{l}\text { + Sistematização. } \\
\text { Projeto de sulcação, } \\
\text { MEIOSI e colheita em } \\
\text { andamento. }\end{array}$ & $\begin{array}{l}\text { + Sistematização com } \\
\text { orientação da usina. } \\
\text { Melhoria da colheita, } \\
\text { da adubação, reduz } \\
\text { combustível, não perde } \\
\text { tanto veneno. }\end{array}$ & $\begin{array}{l}\text { + Curvas de Nível } \\
\text { Redução da erosão e } \\
\text { manutenção das } \\
\text { estradas. }\end{array}$ \\
\hline & $\begin{array}{l}\text { Correção do } \\
\text { Solo }\end{array}$ & $\begin{array}{l}\text { + Análise e Correção } \\
\text { com calcário e outros } \\
\text { produtos químicos }\end{array}$ & $\begin{array}{l}\text { + Análise e Correção } \\
\text { com Calcário e Gesso. }\end{array}$ & $\begin{array}{l}\text { + Análise e Correção } \\
\text { com calcário e gesso. } \\
\text { Fosfatagem na } \\
\text { reforma. }\end{array}$ & $\begin{array}{l}\text { + Análise e Correção } \\
\text { com Calcário anual e } \\
\text { Gesso. } \\
\text { + Testes com esterco } \\
\text { de galinha. }\end{array}$ & $\begin{array}{l}\text { + Análise e Correção } \\
\text { com calcário e gesso. }\end{array}$ \\
\hline & $\begin{array}{l}\text { Aplicação de } \\
\text { Torta de Filtro }\end{array}$ & $\begin{array}{l}\text { + Cota de torta de filtro. } \\
\text { Ajuda na adubação } \\
\text { orgânica. }\end{array}$ & $\begin{array}{l}\text { Não utiliza a cota de } \\
\text { torta de filtro da usina. }\end{array}$ & $\begin{array}{l}\text { + Usa a cota apenas se } \\
\text { for mexer em alguma } \\
\text { curva ou tenha que } \\
\text { remover solo. }\end{array}$ & $\begin{array}{l}\text { - Gostaria de ter a cota } \\
\text { de torta de filtro. }\end{array}$ & Não comentou \\
\hline & $\begin{array}{l}\text { Preparo do } \\
\text { Solo }\end{array}$ & $\begin{array}{l}\text { + Preparo Reduzido } \\
\text { (Dessecação, rotação e } \\
\text { subsolagem) }\end{array}$ & $\begin{array}{l}\text { + Preparo Reduzido } \\
\text { (Dessecação, rotação e } \\
\text { subsolagem) }\end{array}$ & $\begin{array}{l}\text { + Preparo Reduzido } \\
\text { (Dessecação, rotação e } \\
\text { preparo para o } \\
\text { amendoim) }\end{array}$ & $\begin{array}{l}\text { Gradão, grade } \\
\text { intermediária, subsola, } \\
\text { passa a rotativa. Arado } \\
\text { quando a chuva atrasa. }\end{array}$ & $\begin{array}{l}\text { + Preparo reduzido } \\
\text { - Preparo convencional } \\
\text { quando atrasa a } \\
\text { colheita e não } \\
\text { consegue arrendar p } \\
\text { rotação. }\end{array}$ \\
\hline & $\begin{array}{l}\text { Sistema de } \\
\text { Rotação }\end{array}$ & $\begin{array}{l}\text { + Rotação com Soja ou } \\
\text { Amendoim }\end{array}$ & $\begin{array}{l}\text { + Rotação com Soja ou } \\
\text { Amendoim }\end{array}$ & $\begin{array}{l}\text { + Rotação de } 17 \text { meses } \\
\text { com soja, milho } \\
\text { safrinha e amendoim, }\end{array}$ & $\begin{array}{l}\text { + Rotação com } \\
\text { Amendoim }\end{array}$ & $\begin{array}{l}\text { + Rotação com } \\
\text { Amendoim }\end{array}$ \\
\hline Plantio & $\begin{array}{l}\text { Corte das } \\
\text { Mudas }\end{array}$ & - Corte Mecanizado & + Corte Manual & + Corte Manual & $\begin{array}{l}\text { - Corte Mecanizado } \\
\text { Colhedoras danificam } \\
\text { as gemas. Aumenta o }\end{array}$ & $\begin{array}{l}\text { Corte manual } \\
\text { Terceirizado }\end{array}$ \\
\hline
\end{tabular}




\begin{tabular}{|c|c|c|c|c|c|c|}
\hline \multirow[t]{3}{*}{ Processo } & Atividade & Integral / Grande & Intermediário/ Grande & $\begin{array}{c}\text { Intermediário/ } \\
\text { Grande }\end{array}$ & $\begin{array}{l}\text { Intermediário/ } \\
\text { Pequeno }\end{array}$ & Básico / Pequeno \\
\hline & & $\begin{array}{l}\text { Colhedoras danificam as } \\
\text { gemas }\end{array}$ & $\begin{array}{l}\text { colhedoras danificam } \\
\text { as gemas }\end{array}$ & $\begin{array}{l}\text { Colhedoras danificam } \\
\text { as gemas }\end{array}$ & $\begin{array}{l}\text { consumo e dá podridão } \\
\text { do abacaxi. }\end{array}$ & \\
\hline & Plantio & $\begin{array}{l}\text { - Plantio Mecanizado } \\
\text { Maior consumo de } \\
\text { mudas e maior } \\
\text { susceptibilidade à } \\
\text { doenças }\end{array}$ & $\begin{array}{l}\text { + Plantio Manual } \\
\text { Plantio Mecanizado } \\
\text { não distribui } \\
\text { linearmente }\end{array}$ & $\begin{array}{l}\text { - Plantio Manual } \\
\text { Má distribuição das } \\
\text { mudas. Mão de Obra } \\
\text { desqualificada }\end{array}$ & Plantio Mecanizado & $\begin{array}{l}\text { - Plantio manual } \\
\text { terceirizado } \\
\text { Baixa confiança com } \\
\text { relação às adequações } \\
\text { à legislação }\end{array}$ \\
\hline Tratos Culturais & $\begin{array}{l}\text { Controle de } \\
\text { Pragas e Ervas } \\
\text { Daninhas }\end{array}$ & $\begin{array}{l}\text { - Infestação de pragas } \\
\text { em um dos polos (área } \\
\text { em recuperação) } \\
\text { + Mapeamento de pragas } \\
\text { através de drones em } \\
\text { parceria com } \\
\text { Cooperativa } \\
\text { + Bons produtos e } \\
\text { equipamentos no } \\
\text { mercado } \\
\text { + Experimentos de } \\
\text { fornecedores com } \\
\text { inseticidas e herbicidas } \\
\text { + Usa cota de vinhaça da } \\
\text { usina, aplica nas áreas } \\
\text { estratégicas - só cobra o } \\
\text { custo operacional }\end{array}$ & $\begin{array}{l}\text { - Pragas e Ervas } \\
\text { daninhas pioraram } \\
\text { depois do fim das } \\
\text { queimadas. Aumentou } \\
\text { o custo. } \\
\text { - Surgem novas pragas } \\
\text { e leva tempo para } \\
\text { aprender a manejar } \\
\text { + Bons produtos e } \\
\text { equipamentos no } \\
\text { mercado } \\
\text { + Experimentos de } \\
\text { fornecedores com } \\
\text { inseticidas e herbicida }\end{array}$ & $\begin{array}{l}\text { - Pragas e Ervas } \\
\text { daninhas pioraram } \\
\text { depois do fim das } \\
\text { queimadas. Caiu a } \\
\text { produtividade } \\
\text { - Surgem novas pragas } \\
\text { e leva tempo para } \\
\text { aprender a manejar } \\
\text { + Bons herbicidas no } \\
\text { mercado. } \\
\text { + Vinhaça fornecida } \\
\text { pela usina. Só paga o } \\
\text { transporte. }\end{array}$ & $\begin{array}{l}\text { + Serviço de avaliação } \\
\text { e controle de ervas } \\
\text { daninhas e pragas da } \\
\text { associação (MIP) } \\
\text { - Gostaria de ter a cota } \\
\text { de vinhaça da Usina }\end{array}$ & $\begin{array}{l}\text { + Serviço de avaliação } \\
\text { e controle de ervas } \\
\text { daninhas e pragas da } \\
\text { associação (MIP) }\end{array}$ \\
\hline CCT & $\begin{array}{l}\text { Corte, } \\
\text { Carregamento } \\
\text { e Transporte }\end{array}$ & $\begin{array}{l}\text { + Custo é menor do que } \\
\text { o da usina. } \\
\text { - Demanda um alto } \\
\text { investimento e uma }\end{array}$ & $\begin{array}{l}\text { + Negociação de } \\
\text { subsídio com a usina }\end{array}$ & $\begin{array}{l}\text { - É o maior custo } \\
\text { operacional }\end{array}$ & $\begin{array}{l}\text { - Colheita de má } \\
\text { qualidade. Tem que } \\
\text { ficar em cima }\end{array}$ & $\begin{array}{l}\text { - Custo elevado } \\
\text { + Negociação de } \\
\text { subsídio com a usina }\end{array}$ \\
\hline
\end{tabular}




\begin{tabular}{|c|c|c|c|c|c|c|}
\hline \multirow[t]{2}{*}{ Processo } & \multirow[t]{2}{*}{ Atividade } & \multirow{2}{*}{$\begin{array}{l}\text { Integral / Grande } \\
\text { estrutura grande de } \\
\text { pessoal. }\end{array}$} & Intermediário/ Grande & $\begin{array}{c}\text { Intermediário/ } \\
\text { Grande }\end{array}$ & \multirow{2}{*}{$\begin{array}{l}\text { Intermediário/ } \\
\text { Pequeno } \\
\text { + Negociação de } \\
\text { subsídio com a usina } \\
\text { + Serviço da } \\
\text { associação de } \\
\text { avaliação das Perdas }\end{array}$} & \multirow{2}{*}{$\begin{array}{l}\text { Básico / Pequeno } \\
\\
\text { - Elevadas Perdas de } \\
\text { colheita da usina. Tem } \\
\text { que ficar em cima } \\
\text { + Serviço da } \\
\text { Associação de } \\
\text { Avaliação das Perdas }\end{array}$} \\
\hline & & & $\begin{array}{l}\text { + Perdas estão dentro } \\
\text { do normal. Equipe } \\
\text { preparada. } \\
\text { - Mas tem que } \\
\text { fiscalizar }\end{array}$ & $\begin{array}{l}\text { + Negociação de } \\
\text { subsídio com a usina } \\
\text { - Elevadas Perdas de } \\
\text { colheita da usina. Tem } \\
\text { que ficar em cima } \\
\text { + Serviço da } \\
\text { associação de } \\
\text { avaliação das Perdas }\end{array}$ & & \\
\hline \multirow[t]{3}{*}{$\begin{array}{l}\text { Comercializa- } \\
\text { ção }\end{array}$} & $\begin{array}{l}\text { Contratos de } \\
\text { Fornecimento } \\
\text { com as usinas }\end{array}$ & $\begin{array}{l}\text { + Contratos e } \\
\text { relacionamento de longo } \\
\text { prazo } \\
\text { + Contrato coletivo de } \\
\text { fornecimento através da } \\
\text { associação }\end{array}$ & $\begin{array}{l}\text { + Contrato individual } \\
\text { de fornecimento e } \\
\text { relacionamento de } \\
\text { longo prazo } \\
\text { + Concessões de } \\
\text { subsídios, modelo de } \\
\text { remuneração e época } \\
\text { da colheita. }\end{array}$ & $\begin{array}{l}\text { + Contrato individual } \\
\text { de fornecimento e } \\
\text { relacionamento de } \\
\text { longo prazo } \\
\text { + Concessões de } \\
\text { subsídios, modelo de } \\
\text { remuneração e época } \\
\text { da colheita. }\end{array}$ & $\begin{array}{l}\text { + Contrato individual } \\
\text { de fornecimento e } \\
\text { relacionamento de } \\
\text { longo prazo } \\
\text { + Concessão de } \\
\text { subsídio no CCT } \\
\text { - Quem tem maior } \\
\text { volume obtém maior } \\
\text { poder de negociação } \\
\text { - Não tem cota de } \\
\text { subprodutos }\end{array}$ & $\begin{array}{l}\text { + Contrato individual } \\
\text { de fornecimento e } \\
\text { relacionamento de } \\
\text { longo prazo } \\
\text { + Concessão de } \\
\text { subsídio no CCT } \\
\text { - Quem tem maior } \\
\text { volume obtém } \\
\text { melhores subsídios }\end{array}$ \\
\hline & ATR relativo & $\begin{array}{l}\mathrm{N} \text { - Para quem faz } \\
\text { entrega linear, não faz } \\
\text { diferença. }\end{array}$ & $\begin{array}{l}\text { + Negociação } \\
\text { diferenciada com a } \\
\text { usina }\end{array}$ & $\begin{array}{l}\text { + Negociação } \\
\text { diferenciada com a } \\
\text { usina }\end{array}$ & $\begin{array}{l}\text { - Com o ATR relativo } \\
\text { você acaba perdendo } \\
\text { para aqueles que não } \\
\text { tão nem aí para a coisa. }\end{array}$ & $\begin{array}{l}\text { - Preferia antes porque } \\
\text { a minha cana tinha um } \\
\text { ATR melhor, porque } \\
\text { cortava tarde, mas } \\
\text { tinha gente que ficava } \\
\text { em desvantagem. }\end{array}$ \\
\hline & Preço do ATR & $\begin{array}{l}\text { - Modelo } \\
\text { CONSECANA não }\end{array}$ & $\begin{array}{l}\text { - Fórmula } \\
\text { CONSECANA é } \\
\text { injusta }\end{array}$ & $\begin{array}{l}\text { - As revisões do } \\
\text { CONSECANA não } \\
\text { acontecem }\end{array}$ & $\begin{array}{l}\text { - As revisões do } \\
\text { CONSECANA não } \\
\text { acontecem }\end{array}$ & $\begin{array}{l}\text { - O preço está aquém } \\
\text { por questões } \\
\text { mercadológicas. }\end{array}$ \\
\hline
\end{tabular}




\begin{tabular}{|c|c|c|c|c|c|c|}
\hline \multirow[t]{2}{*}{ Processo } & \multirow[t]{2}{*}{ Atividade } & Integral / Grande & Intermediário/ Grande & $\begin{array}{c}\text { Intermediário/ } \\
\text { Grande }\end{array}$ & \multirow{2}{*}{\begin{tabular}{l}
\multicolumn{1}{c}{$\begin{array}{l}\text { Intermediário/ } \\
\text { Pequeno }\end{array}$} \\
- Não existe mérito de \\
certificação;
\end{tabular}} & \multirow[t]{2}{*}{ Básico / Pequeno } \\
\hline & & $\begin{array}{l}\text { acompanhou as } \\
\text { transformações do setor; } \\
\text { - Não existe mérito de } \\
\text { certificação; } \\
\text { - Não existe mérito do } \\
\text { risco assumido (CCT); }\end{array}$ & $\begin{array}{l}\text { - O modelo não é } \\
\text { regionalizado } \\
\text { - Não existe mérito de } \\
\text { certificação; }\end{array}$ & $\begin{array}{l}\text { - O fornecedor não } \\
\text { pode pagar pela } \\
\text { ineficiência da Usina; }\end{array}$ & & \\
\hline \multirow[t]{2}{*}{$\begin{array}{l}\text { Gestão do } \\
\text { Negócio }\end{array}$} & $\begin{array}{l}\text { Planejamento } \\
\text { e Gestão de } \\
\text { Resultados }\end{array}$ & $\begin{array}{l}\text { + Planejamento e } \\
\text { controle estruturado } \\
\text { envolvendo as áreas da } \\
\text { empresa. } \\
\text { + Projeções econômicas } \\
\text { através de estimativas ao } \\
\text { longo dos cortes. }\end{array}$ & $\begin{array}{l}\text { + Acompanhamento } \\
\text { anual da } \\
\text { produtividade, dos } \\
\text { custos totais e receitas. }\end{array}$ & $\begin{array}{l}\text { + Acompanhamento da } \\
\text { produtividade, custos } \\
\text { por etapa, lucro e } \\
\text { remuneração do } \\
\text { capital. }\end{array}$ & $\begin{array}{l}\text { + Acompanhamento da } \\
\text { produtividade, custos } \\
\text { por etapa, lucro e } \\
\text { remuneração do } \\
\text { capital. }\end{array}$ & $\begin{array}{l}\text { + Acompanhamento da } \\
\text { produtividade, custos } \\
\text { por etapa, lucro e } \\
\text { remuneração do } \\
\text { capital; }\end{array}$ \\
\hline & $\begin{array}{l}\text { Adequação à } \\
\text { Legislação }\end{array}$ & $\begin{array}{l}\text { + Departamento Jurídico } \\
\text { interno para adequação à } \\
\text { legislação; } \\
\text { + Certificação Socio } \\
\text { Ambiental, há } 4 \text { anos }\end{array}$ & $\begin{array}{l}\text { - Legislação } \\
\text { Trabalhista só } \\
\text { beneficia o empregado } \\
\text { - Radicalismo na } \\
\text { Legislação ambiental; } \\
\text { + Departamento } \\
\text { Jurídico da Associação } \\
\text { + Participa do } \\
\text { programa de } \\
\text { certificação da } \\
\text { Associação }\end{array}$ & $\begin{array}{l}\text { + Assessoria Jurídica } \\
\text { da Associação para } \\
\text { adequação à legislação } \\
\text { trabalhista e ambiental } \\
\text { + Participa do } \\
\text { programa de } \\
\text { certificação da } \\
\text { Associação }\end{array}$ & $\begin{array}{l}\text { - Migração para } \\
\text { operações } \\
\text { mecanizadas, } \\
\text { minimizar problemas } \\
\text { trabalhistas. } \\
\text { + Assessoria Jurídica } \\
\text { da Associação para } \\
\text { adequação à legislação } \\
\text { trabalhista e ambiental } \\
\text { + Participa do } \\
\text { programa de } \\
\text { certificação da } \\
\text { Associação }\end{array}$ & $\begin{array}{l}\text { + Não tem funcionário } \\
\text { + Assessoria Jurídica } \\
\text { da Associação para } \\
\text { adequação à legislação } \\
\text { trabalhista e ambiental } \\
\text { + Participa do } \\
\text { programa de } \\
\text { certificação da } \\
\text { Associação }\end{array}$ \\
\hline
\end{tabular}




\begin{tabular}{|c|c|c|c|c|c|c|}
\hline Processo & Atividade & Integral / Grande & Intermediário/ Grande & $\begin{array}{l}\text { Intermediário/ } \\
\text { Grande }\end{array}$ & $\begin{array}{l}\text { Intermediário/ } \\
\text { Pequeno }\end{array}$ & Básico / Pequeno \\
\hline & $\begin{array}{l}\text { Governança e } \\
\text { Sucessão }\end{array}$ & $\begin{array}{l}\text { + Formação de } \\
\text { condomínio entre } \\
\text { familiares. } \\
\text { + Estrutura Societária e } \\
\text { Governança definidas. }\end{array}$ & $\begin{array}{l}\text { - Preocupação com a } \\
\text { descontinuidade na } \\
\text { próxima geração } \\
\text { - Inexistência de } \\
\text { regras, funções e } \\
\text { responsabilidades. }\end{array}$ & $\begin{array}{l}\text { - Preocupação com a } \\
\text { descontinuidade na } \\
\text { próxima geração } \\
\text { - Inexistência de } \\
\text { regras, funções e } \\
\text { responsabilidades }\end{array}$ & $\begin{array}{l}\text { - Preocupação com a } \\
\text { descontinuidade na } \\
\text { próxima geração } \\
\text { - Inexistência de } \\
\text { regras, funções e } \\
\text { responsabilidades. }\end{array}$ & $\begin{array}{l}\text { - Preocupação com a } \\
\text { descontinuidade na } \\
\text { próxima geração } \\
\text { - Inexistência de } \\
\text { regras, funções e } \\
\text { responsabilidades. }\end{array}$ \\
\hline $\begin{array}{l}\text { Gestão do } \\
\text { Negócio }\end{array}$ & $\begin{array}{l}\text { Atuação } \\
\text { integrada entre } \\
\text { produtores }\end{array}$ & $\begin{array}{l}\text { + Participação em } \\
\text { conselhos e diretorias de } \\
\text { associações e } \\
\text { cooperativas. } \\
\text { + Operações conjuntas } \\
\text { via associação (Contrato } \\
\text { de planejamento, plantio } \\
\text { e colheita). }\end{array}$ & $\begin{array}{l}\text { + Participação em } \\
\text { conselhos e diretorias } \\
\text { de associações e } \\
\text { cooperativas. } \\
\text { - Baixa participação e } \\
\text { troca de informações } \\
\text { entre produtores. } \\
\text { - Pool de compras } \\
\text { trariam maiores } \\
\text { descontos. }\end{array}$ & $\begin{array}{l}\text { + Participação em } \\
\text { conselhos e diretorias } \\
\text { de associações e } \\
\text { cooperativas. } \\
\text { + Orientações das } \\
\text { cooperativas para obter } \\
\text { melhores condições de } \\
\text { compra. } \\
\text { + Núcleos de } \\
\text { desenvolvimento. } \\
\text { - Poderia otimizar } \\
\text { estrutura e } \\
\text { funcionários através do } \\
\text { compartilhamento. }\end{array}$ & $\begin{array}{l}\text { - Pool de compras } \\
\text { trariam maiores } \\
\text { descontos. } \\
\text { - Poderia otimizar } \\
\text { estrutura e } \\
\text { funcionários através do } \\
\text { compartilhamento ou } \\
\text { de condomínio. } \\
\text { - Os produtores } \\
\text { precisam se unir para } \\
\text { aumentar o poder de } \\
\text { negociação com as } \\
\text { usinas. } \\
+ \text { A troca de } \\
\text { informações melhorou } \\
\text { com o programa de } \\
\text { qualificação da } \\
\text { associação. }\end{array}$ & $\begin{array}{l}\text { + Compras dos } \\
\text { produtos e condições } \\
\text { de financiamento pelas } \\
\text { cooperativas. } \\
\text { + Programa de } \\
\text { qualificaçãa da } \\
\text { associação. } \\
\text { +Serviços técnicos da } \\
\text { associação. }\end{array}$ \\
\hline
\end{tabular}

Fonte: Elaborado pelo autor 
Ao analisar as experiências comparativamente foi possível perceber que, tanto o porte, quanto o grau de verticalização são indutores de diferenciações em alguns aspectos das experiências. Outros aspectos independem do porte ou do grau de verticalização e podem ser específicos do perfil de um ou mais entrevistados.

Através da Figura 15 é possível visualizar este conjunto de aspectos. Uma escala de cinza foi utilizada para criar uma percepção visual de diferenciação entre grupos de produtores em cada atividade.

As principais distinções identificadas entre as percepções de produtores grandes e pequenos são as seguintes:

- Pesquisa e desenvolvimento de variedades: os grandes demonstraram insatisfação com a evolução da pesquisa e desenvolvimento de novas variedades. Os pequenos não mencionaram.

- Parceria com os fabricantes de insumos: um aspecto positivo da experiência, apontado apenas pelos grandes produtores, foi a realização de experimentos nas suas propriedades por empresas fornecedoras de insumos agrícolas, o que gera oportunidades de aprender, inovar e, consequentemente ganhar produtividade.

- Benefícios obtidos nos contratos de fornecimento com as usinas: os grandes produtores obtêm maiores vantagens comerciais e operacionais nas negociações devido ao volume de fornecimento.

- Atuação mais ativa nas diretorias e conselhos de cooperativas e associações: os grandes participam de diretorias e conselhos de associações e cooperativas.

Com respeito aos diferentes níveis de verticalização, a experiência dos produtores se diferencia nas seguintes atividades:

- Dimensionamento dos equipamentos: o produtor integral tem toda a estrutura de equipamentos e presta serviços de CCT. Já os produtores intermediários não acham que vale a pena investir nos equipamentos por não ter escala para absorver o investimento e o custo. Pelo mesmo motivo o produtor básico só tem a estrutura para realizar os tratos culturais.

- Época da colheita - O produtor Integral, em conjunto com outros produtores, via um planejamento integrado da época da colheita, tem autonomia para planejar a época da colheita. Os produtores intermediários não têm autonomia para planejar a melhor época para colher. No entanto, conseguiram negociar com a usina a colheita precoce que para 
eles é a mais conveniente por questões agronômicas e de planejamento. Já o produtor Pequeno / Básico, que não tem domínio sobre a época da realização da colheita, convive com diversas restrições operacionais.

- Custos e qualidade da colheita: Os produtores que terceirizam o CCT têm menor domínio sobre os custos da qualidade da colheita.

Outras características são comuns aos dois produtores intermediários grandes, tais como a produção de MPBs combinadas com Meiosi e realização de plantio manual.

Uma das características exclusivas do produtor Integral / Grande é a instituição da modalidade de condomínio entre familiares, que proporcionou a estruturação de um modelo de governança e sucessão, além de contar com uma estrutura administrativa com profissionais especializados para planejar e tomar decisões técnicas e gerenciais.

A questão governança e sucessão é crítica para os demais entrevistados. No entanto, os grandes já preveem a contratação de uma consultoria para ajudá-los a estruturar um modelo, enquanto os pequenos apostam no comprometimento da próxima geração de permanecer no negócio.

Quanto aos objetivos com a produção de cana-de-açúcar, também foi possível perceber uma diferenciação entre os produtores. O produtor Integral se diferenciou dos demais por apresentar uma preocupação com a sustentabilidade do setor, os três produtores Intermediários estão orientados para lucratividade dos seus negócios, enquanto o produtor básico colocou em primeiro lugar a sua preocupação com a manutenção da propriedade quase centenária da família.

Alguns aspectos são comuns a todos, como por exemplo, a experiência positiva com o serviço de mapeamento de solos, com a adoção da rotação de culturas ou a satisfação com os benefícios da sistematização.

\subsection{Construção das personas}

A partir desta análise de cores, foi possível perceber três padrões de comportamento, a partir dos quais foram construídas as Personas. 
Figura 17 - Análise comparativa para construção das personas

Persona 3 - Antônio

Básico/Pequeno

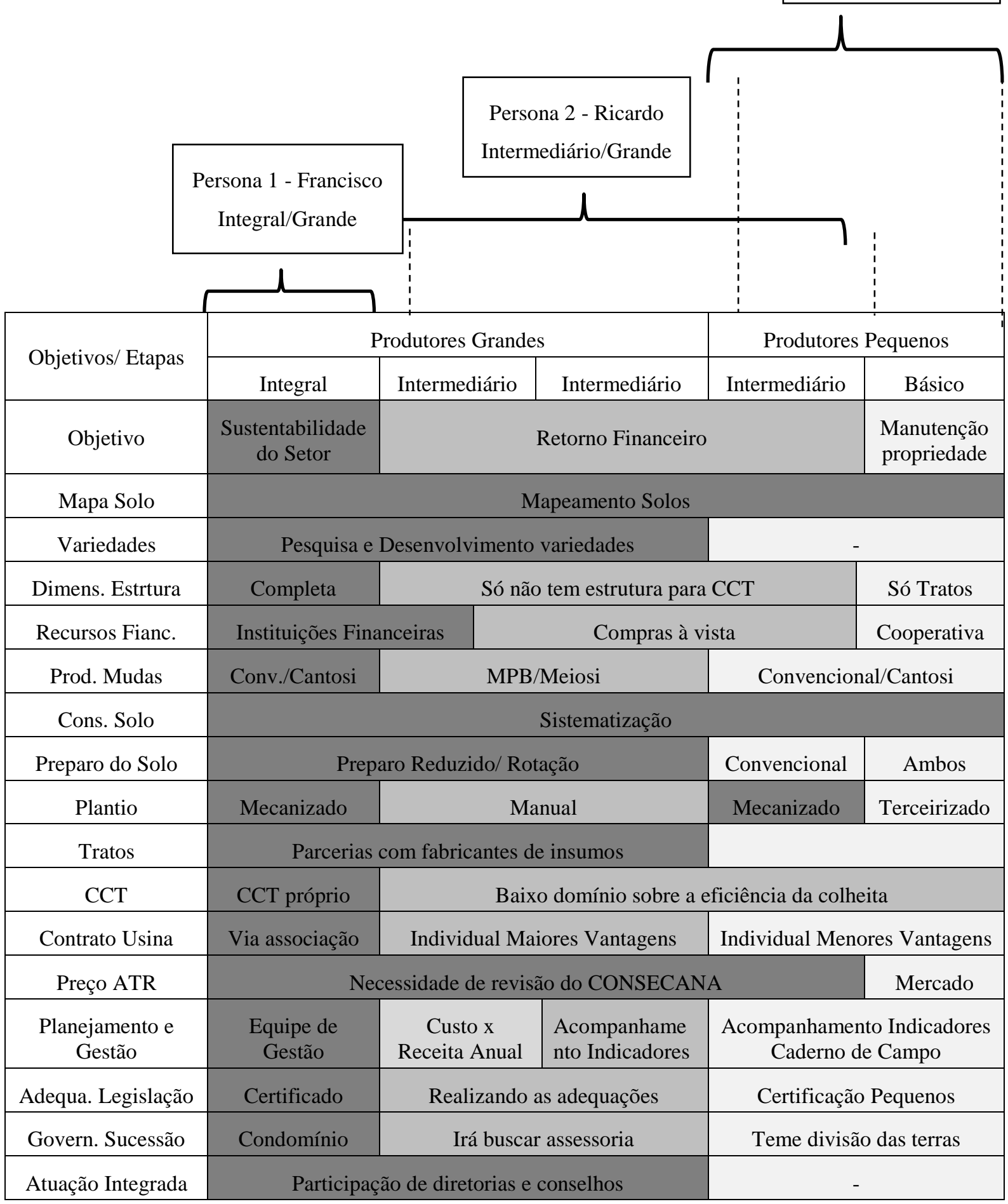

Fonte: Elaborado pelo autor 
A Persona 1 foi construída com base no padrão de comportamento com predominância do cinza escuro, que reúne características compartilhadas pelos grandes produtores, além das características que são exclusivas do produtor Integral / Grande. A Persona 2 teve predominância do tom cinza médio, que também reúne as características dos grandes produtores, porém combinadas com características dos produtores intermediários. Já a Persona 3 foi construída com base nos padrões representados pelo tom cinza claro, reunindo características dos pequenos produtores e, predominantemente do produtor básico.

Cada Persona foi representada no espaço de uma página, com um nome e uma foto fictícios, onde foram descritos seus objetivos, pontos considerados críticos, estruturas organizacionais e informações sobre seus processos produtivos (Figuras 18, 19 e 20).

Francisco Antonelli é a Persona proposta para representar os padrões de comportamento de um grupo de produtores de Grande Porte, com grau de verticalização Integral, ou seja, tem estrutura para realizar a colheita e o carregamento. Ficando a cargo da usina apenas o transporte. Francisco tem uma preocupação com a sustentabilidade do setor. Participa de diretorias e conselhos de associações e cooperativas. Acredita que os produtores podem se unir para compartilhar estrutura de gestão, de equipamentos e de funcionários, diluindo custos e tornando-se mais independentes das usinas. Participa de um modelo coletivo de produção e fornecimento organizado pela associação. Possui certificações socioambientais há três anos. O negócio familiar está formalizado através de um condomínio com modelo de governança e sucessão estruturado.

Ricardo Soares é a Persona proposta para representar os padrões de comportamento de um grupo de produtores com grau de verticalização Intermediário de Grande Porte. Ricardo e os primos dividem a gestão das propriedades onde cada um exerce uma função. É um produtor bastante orientado para a excelência dos seus processos produtivos. Busca continuamente alternativas tecnológicas e operacionais para melhorar a sua eficiência, sempre analisando os impactos nos custos, na produtividade e na qualidade. Uma das suas maiores dores está relacionada à qualidade da colheita realizada pela usina, que vem impactando na longevidade dos canaviais. Já atuou diversas vezes nas diretorias e conselhos das associações e cooperativas. Quanto à questão sucessão, considera o tema delicado de ser tratado entre os familiares e acredita que será necessário contratar uma consultoria para auxiliá-los. 
Antônio Moraes é a Persona que representa as características do produtor de Pequeno Porte com grau de verticalização Básico. Antônio é um produtor que administra a propriedade para os irmãos e realiza todas as atividades com a ajuda do filho e do sobrinho. Sempre terceirizou a atividade de plantio e colheita para a usina. Há alguns anos, a usina decidiu não mais realizar este serviço. Ele passou a utilizar então os serviços de empreiteiros. No entanto, se sente um pouco inseguro com a adequação legal destes prestadores. Há dois anos entrou no programa de qualificação da associação e vem percebendo diversos ganhos com a profissionalização. Ele começou a produzir suas próprias mudas, fazendo uso da carta de solo, e utiliza o caderno de campo para gerenciar seus resultados. Com este processo, ele vem percebendo outras oportunidades para melhorar os seus resultados, como por exemplo a utilização da Meiosi para reduzir os custos de transporte. Uma de suas maiores dores é a realização tardia da colheita. Ele se vê limitado para realizar outras operações, tais como a própria Meiosi e a rotação de culturas. Como as terras da família já foram divididas entre os tios, ele tem uma grande preocupação com manutenção da propriedade. Mas acredita que a próxima geração está comprometida com a continuidade ao negócio. 
Figura 18 - Persona que representa o Produtor Integral / Grande

\begin{tabular}{|c|c|}
\hline $\begin{array}{l}\text { FRANCISCO ANTONELLI } \\
65 \text { anos, } 1 \text { filho sócio no negócio } \\
\text { Graduação em Direito } \\
7.300 \text { ha de áreas agrícolas } \\
\text { Produtor Integral/Grande }\end{array}$ & $\begin{array}{l}\text { "Os produtores são o elo da cadeia produtiva que } \\
\text { vem se enfraquecendo. Estão ficando cada vez } \\
\text { mais dependentes das usinas." }\end{array}$ \\
\hline $\begin{array}{l}\text { Objetivos e Estratégias } \\
\text { Garantir a sustentabilidade do } \\
\text { negócio e do setor. } \\
\text { - Fortalecimento do associativismo e } \\
\text { cooperativismo. }\end{array}$ & $\begin{array}{l}\text { Estrutura e Gestão } \\
\text { - Condomínio Familiar - irmãos/filho/sobrinhos } \\
\text { - Modelo de Governança e Sucessão implantado } \\
\text { - Atuação em conselhos e diretorias de associações e } \\
\text { cooperativas } \\
\text { Processo Produtivo } \\
\text { - A maioria das operações são mecanizadas } \\
\text { - Rotação com soja ou amendoim } \\
\text { - Produção de mudas no método convencional } \\
\text { - Estrutura completa, com exceção do transporte } \\
\text { - Participa de um modelo coletivo de produção e } \\
\text { - fornecimento organizado pela associação } \\
\text { Realiza serviços de plantio e colheita para outros }\end{array}$ \\
\hline
\end{tabular}

Fonte: Elaborado pelo autor 
Figura 19 - Persona que representa o Produtor Intermediário / Grande

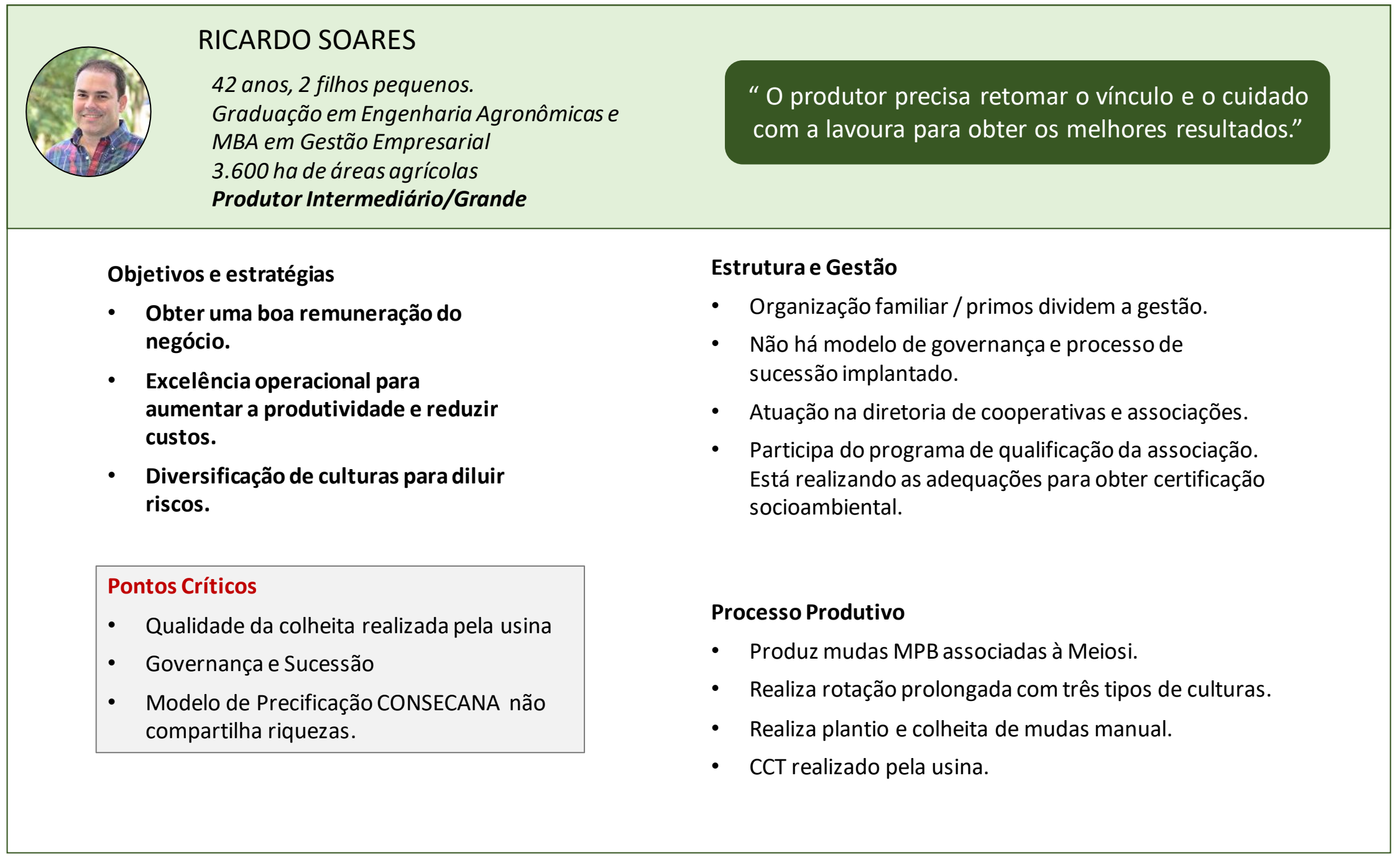

Fonte: Elaborado pelo autor 
Figura 20 - Persona que representa o Produtor Básico / Pequeno

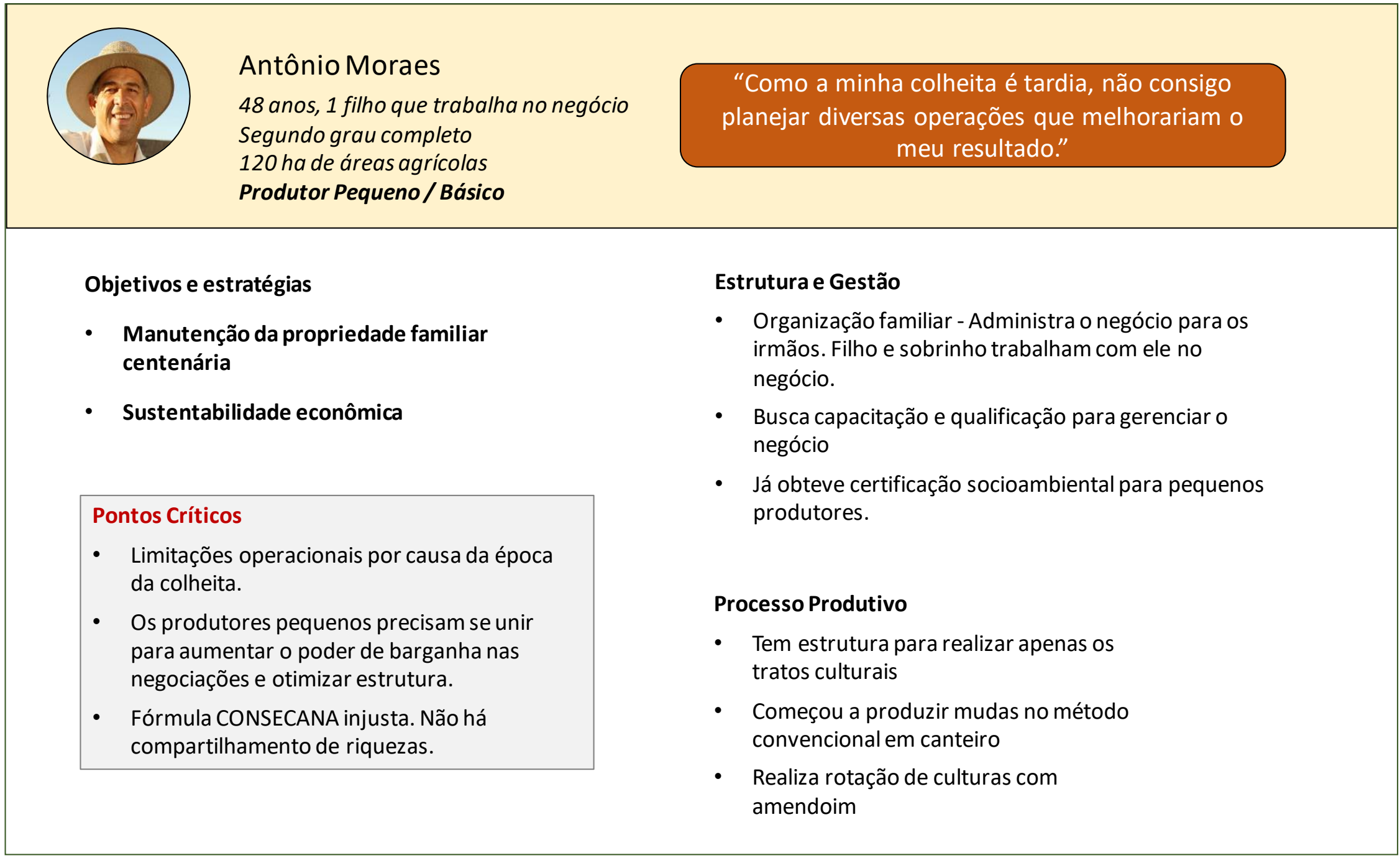

Fonte: Elaborado pelo autor 


\section{MAPEAMENTO DAS EXPERIÊNCIAS E IDENTIFICAÇÃO DE OPORTUNIDADES}

\subsection{Mapeamento das Experiências}

Através de uma ferramenta de diagramação, as experiências de cada persona foram mapeadas. Os elementos que fizeram parte do mapa foram:

a) Descrição resumida de cada Persona na parte superior do mapa, incluindo seus objetivos e motivações;

b) Fases e atividades dos processos, mapeadas no capítulo 5;

c) Representação das percepções positivas e negativas ao longo dos processos, através de uma curva, utilizando-se de subidas e descidas para representar os aspectos positivos e negativos. Segundo Kalbach (2017), este estilo tornou-se uma convenção no mapeamento de experiências. Embora seja representada de forma gráfica e sugira uma quantificação, segundo o autor, raramente estas informações são derivadas de investigações quantitativas. Em geral, são estimadas de modo intuitivo pelas pessoas que realizaram entrevistas ou pelo grupo empenhado em olhar os processos pela perspectiva do cliente.

d) Pensamentos relacionados aos pontos altos e baixos da curva foram representados através de citações derivadas das entrevistas, porém transformadas em um conteúdo mais conciso.

e) Identificação de aspectos que podem gerar oportunidades para que os atores que participam do ecossistema do produtor de cana-de-açúcar, incluindo os próprios produtores, possam repensar suas ações e suas interações. Os aspectos que podem gerar oportunidades foram classificados da seguinte forma:

- Boas Práticas são oportunidades que estão relacionadas aos pontos altos das experiências e podem servir de referências para outros produtores, assim como para os agentes do setor, como associações, cooperativas, fabricantes, fornecedores, centros de pesquisa, etc.

- Outras oportunidades estão relacionadas às Dores dos produtores, ou seja, problemas que impactam nos resultados do seu negócio e para os quais ele ainda não encontrou solução. 
- Algumas oportunidades estão relacionadas a Possibilidades de Melhoria, ou seja, a uma percepção do produtor de que determinadas soluções que estão disponíveis no mercado poderiam ajudá-lo a melhorar seus processos.

- Por fim, outro tipo de oportunidade identificada está relacionada às Percepções

Distintas entre Produtores, significando que, devido à não uniformidade de conhecimento e informações sobre determinadas tecnologias, produtores podem estar obtendo níveis distintos de benefícios ou performances em determinadas atividades.

A seguir são apresentados os diagramas das experiências mapeados para cada Persona. Os diagramas em escala legível foram impressos em tamanho 90 x $43 \mathrm{~cm}$ e estão inseridos no envelope anexado ao final do trabalho. 
Figura 21 - Mapeamento da Experiência de Produtor Integral / Grande ${ }^{21}$

\section{PERSONA: FRANCISCO ANTONELLI/Produtuor Imegral/ Grande}

18 .

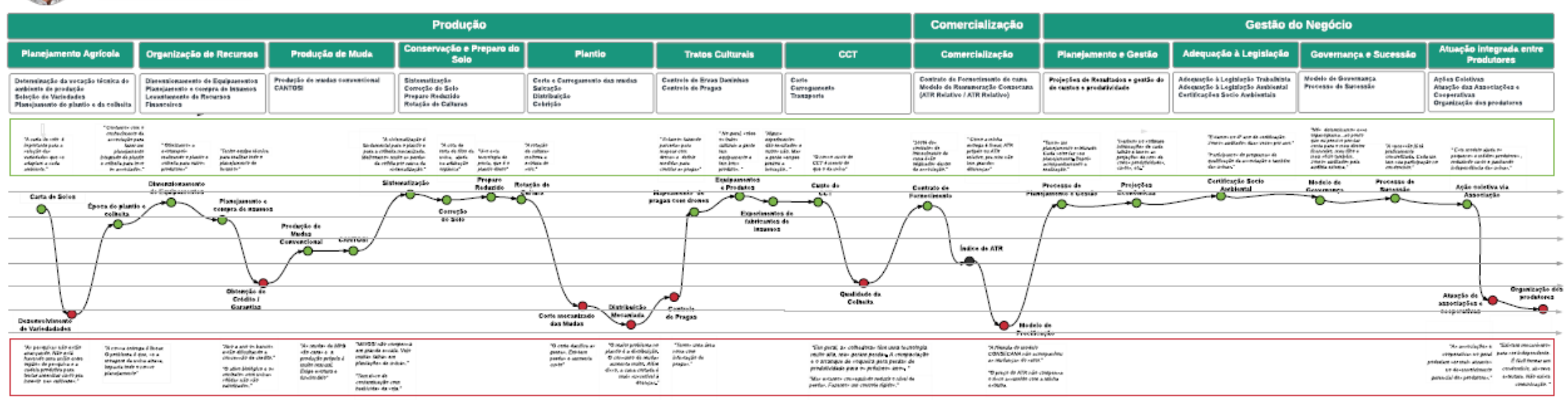

\begin{tabular}{|c|c|c|c|c|c|c|c|c|c|c|c|}
\hline 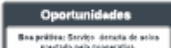 & 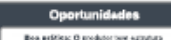 & 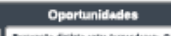 & & & & & & & & . & \\
\hline 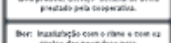 & \pm & 5 & $=$ & 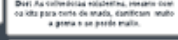 & $=$ & 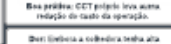 & $y$ & $5=$ & -5 & \pm & 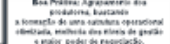 \\
\hline 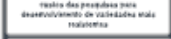 & & 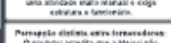 & & $y_{3}=$ & $5=$ & \pm & & $\pm=$ & $\Rightarrow$ & & \\
\hline$=0$ & & 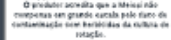 & & 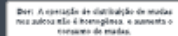 & & & & & & & $=5$ \\
\hline$=$ & $\equiv$ & $=$ & $=$ & $=$ & $=$ & $\equiv$ & $n=$ & Em & $\equiv$ & $\equiv$ & $\equiv$ \\
\hline
\end{tabular}

Fonte: Elaborado pelo autor 
Figura 22 - Mapa da Experiência do Produtor Intermediário / Grande ${ }^{22}$

Persona: RICARDO SOARES / Produthor intermedilariolorende

(12)

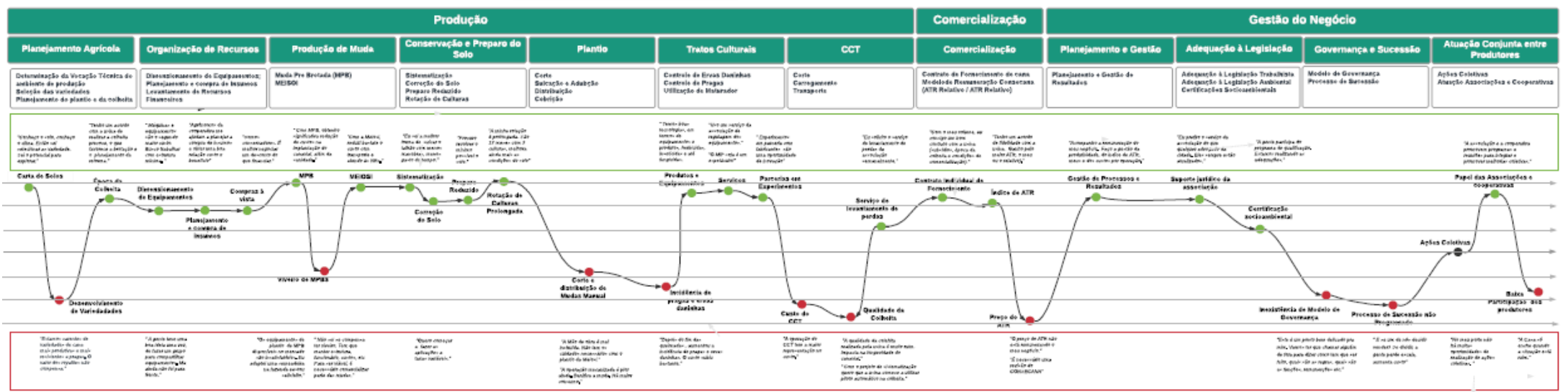

\begin{tabular}{|c|c|c|c|c|c|c|c|c|c|c|c|}
\hline oportanitidates & Oportumidactes & Oportunitades & Oportumidades & 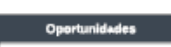 & Oportumitadests & 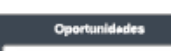 & Opotanimbates & 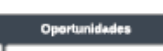 & 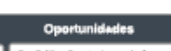 & Oportunidatestes & Oportunibeats. \\
\hline 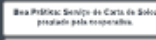 & 5 & 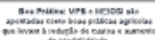 & 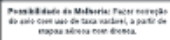 & 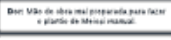 & 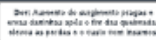 & 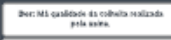 & 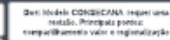 & $y$ & 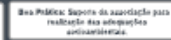 & 5 & $y=9$ \\
\hline$=$ & 5 & and & $=5$ & 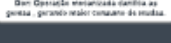 & $5=$ & 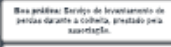 & & & 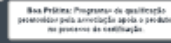 & & \\
\hline & & $7=$ & & & $=$ & $=$ & & & & & \\
\hline & & & & & $2=$ & & & & & & \\
\hline Evam & $=$ & $=$ & $E$ & $\equiv$ & $\equiv$ & $=$ & $=$ & $=$ & $\equiv$ & $\equiv$ & $E$ \\
\hline
\end{tabular}

Fonte: Elaborado pelo autor 
Figura 23 - Mapa da Experiência do Produtor Pequeno / Básico ${ }^{23}$

Persona: Antônio Moraes I Produturor BAscico P Pequeno

(2)

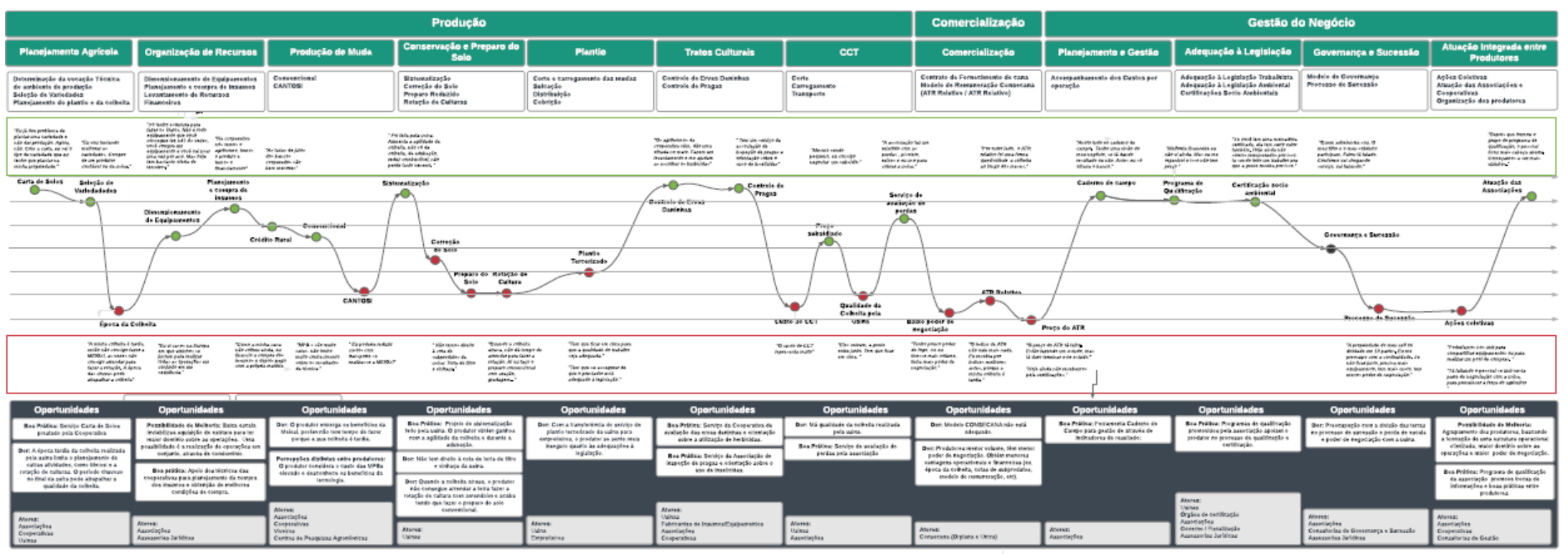

Fonte: Elaborado pelo autor

${ }^{23} \mathrm{O}$ diagrama em escala legível encontra-se inserido no envelope anexado ao final do trabalho. 


\subsection{Análise comparativa das Experiências ${ }^{24}$}

Uma versão resumida de cada curva foi construída para que fosse possível a realização de uma análise comparativa sobre os aspectos que diferenciam as experiências das três personas (Figura 24).

Figura 24: Análise comparativa das experiências mapeadas ${ }^{25}$

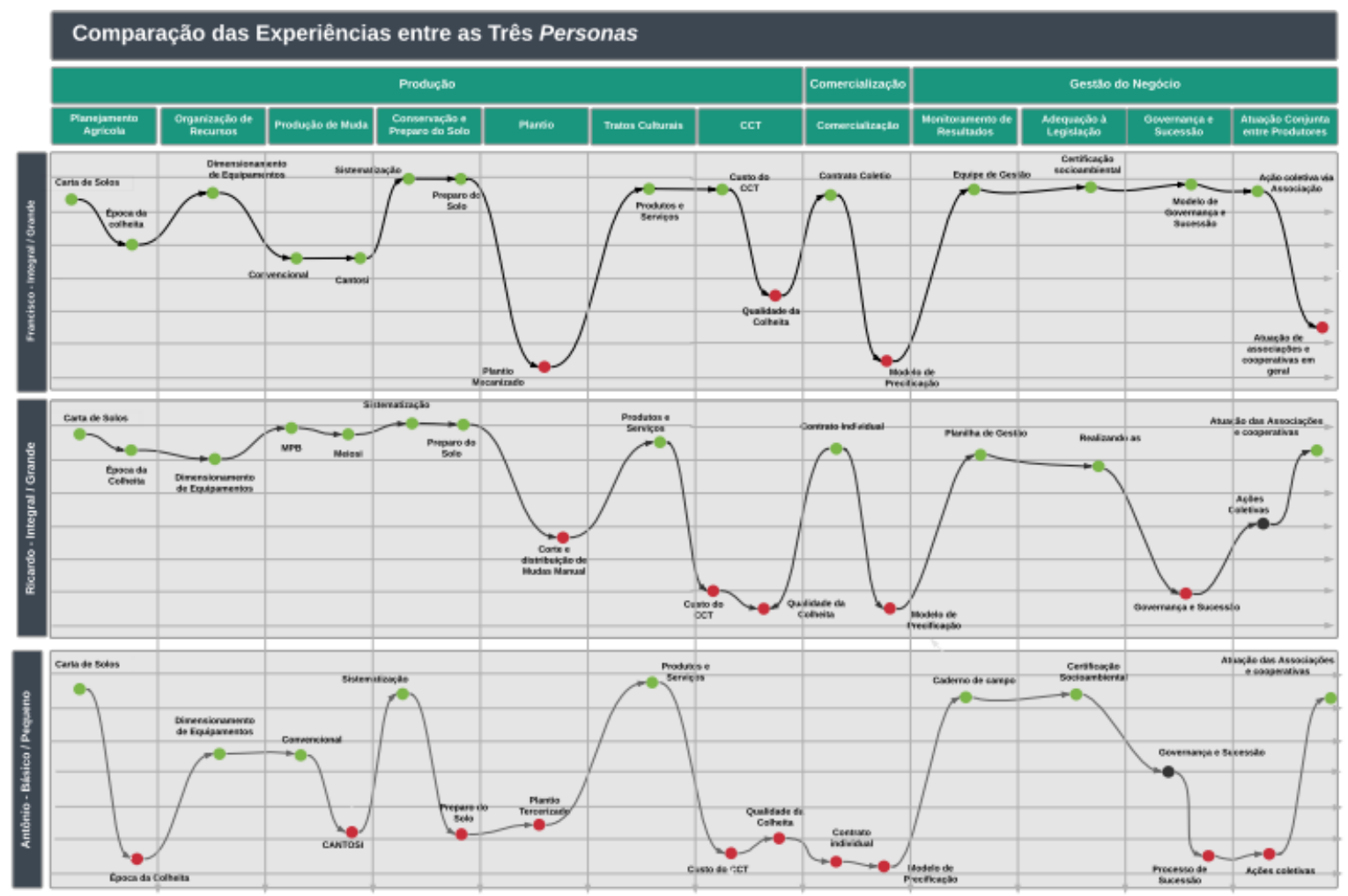

Fonte: Elaborado pelo autor

A figura em escala legível está inserida no envelope anexado no final do trabalho.

Serão destacados abaixo os principais aspectos que diferenciam as experiências das três personas. Estes aspectos, assim como os demais pontos identificados nas curvas de cada persona serão discutidos em maior profundidade no próximo tópico, juntamente com a análise das oportunidades levantadas.

a) Planejamento da época da colheita: Ricardo e Francisco apresentam um nível de satisfação mais elevado neste aspecto. Francisco, acredita que obtém ganhos com a otimização da época da colheita realizada através de um planejamento integrado via associação. Ricardo,

\footnotetext{
${ }^{25}$ A análise comparativa em escala legível encontra-se inserido no envelope anexado ao final do trabalho.
} 
embora não tenha a atividade de planejamento da colheita sob seu domínio, conseguiu negociar com a usina a realização da colheita em época precoce, o que para ele é satisfatório, por motivos agronômicos e por motivos relacionados ao planejamento das atividades durante a reforma. Já para Antônio, o produtor Básico / Pequeno, a época tardia da realização da colheita pela usina causa limitações na realização de outras atividades que poderiam lhe trazer ganhos de eficiência e produtividade. Além disso, o período chuvoso do final da safra pode impactar a qualidade da sua colheita.

b) Dimensionamento de equipamentos: Francisco, que tem estrutura completa, consegue otimizá-la ao prestar serviços de plantio e colheita para outros associados dentro de um modelo coletivo de realização de operações. Ricardo busca trabalhar com uma estrutura mínima. A dispersão de suas terras inviabiliza o investimento na estrutura do CCT. Para Antônio, a baixa escala produtiva, inviabiliza a aquisição da maior parte da estrutura.

c) Produção de Mudas: Neste aspecto, Ricardo é quem apresenta um maior nível de satisfação com os resultados obtidos, através do sistema de produção de MPBs associadas à Meiosi. Francisco, embora reconheça os benefícios das MPBs, considera que o custo e a tecnologia envolvidos ainda não compensam. Ele também prefere o sistema de Cantosi à Meiosi pelos riscos envolvidos na produção em grande escala. Antônio também considera o custo das MPBs elevado. Adota a Cantosi devido à restrição da época de plantio da Meiosi.

d) Preparo do Solo - Quanto ao preparo do solo, todas as personas realizam o cultivo mínimo associado à rotação de culturas. Ricardo demonstra um nível maior de satisfação com os resultados obtidos em decorrência do seu sistema de rotação prolongado. Já Antônio, em decorrência do atraso da colheita, algumas vezes se vê impossibilitado de arrendar a área para a plantação da cultura de rotação. Neste caso, realiza o preparo convencional do solo.

e) Plantio - Quanto à etapa do plantio existe uma insatisfação forte com a tecnologia de plantio mecanizada. Para Francisco, a operação de distribuição das mudas é um dos pontos mais críticos relacionados à tecnologia no processo produtivo. Ricardo, prefere adotar o plantio manual, principalmente por se tratar de Meiosi. No entanto, considera a mão de obra mal preparada para realizar o serviço. Antônio terceiriza a atividade do plantio, que também é realizada manualmente. Para ele, o ponto crítico está relacionado ao possível descumprimento das exigências legais pelos empreiteiros.

f) Custo da colheita - Francisco relata que consegue reduzir os seus custos da operação ao internalizar a operação de colheita. Ele consegue cobrar pelos serviços prestados, um valor 
inferior ao da usina. Ricardo e Antônio, embora com subsídio no valor do serviço, obtido com a usina, consideram o custo das operações de CCT elevado.

g) Qualidade da colheita - A qualidade da colheita mecanizada é um fator importante para todos os produtores. Para Francisco, embora existam pontos de melhoria na tecnologia, ele consegue realizar um controle rígido das perdas e dos danos ao canavial. Para Ricardo e Antônio, as equipes das usinas realizam um trabalho de má qualidade, descumprindo os padrões operacionais, o que leva a perdas e impactos na longevidade do canavial.

h) Contratos de Fornecimento - Ricardo, que mantém um contrato individual de fornecimento com as usinas, obtém uma série de vantagens na negociação devido ao seu volume elevado. Antônio, que também tem um contrato individual de fornecimento com a usina, é quem apresenta um nível mais baixo na curva. Devido ao seu baixo volume de fornecimento, obtém menores vantagens operacionais e de remuneração. Francisco fornece para a usina através de um contrato coletivo de fornecimento. Segundo ele, quem se beneficia mais com este tipo de contrato são os pequenos e médios produtores.

i) Planejamento e gestão - Embora as três personas adotem níveis distintos de gestão, este é um ponto alto nas suas curvas de experiência. Francisco conta com uma estrutura administrativa e de gestão que possibilita a realização de um processo de planejamento e gestão estruturado. Ricardo tem seus processos produtivos estabelecidos e monitorados, com análises financeiras sobre o negócio, viabilizando a tomadas de decisão assertivas. Antônio, através do caderno de campo, começou a gerenciar seu negócio através de indicadores de resultado, monitorando o desempenho por etapa do processo.

j) Governança e Sucessão - Francisco conta com um modelo de governança e sucessão estruturado, viabilizado pela constituição de um condomínio entre familiares. Ricardo reconhece a necessidade de estabelecer um modelo de governança e sucessão para garantir a sustentabilidade do negócio. Antônio se preocupa com possíveis divisões de terras e perda de escala, como já ocorreu na geração do seu pai. No entanto, ele aposta no comprometimento da próxima geração para manter as terras unidas e dar continuidade ao negócio.

k) Ações Coletivas - Francisco acredita que uma das saídas para a sustentabilidade do setor é a realização de ações coletivas. Ricardo não percebe oportunidades de realização de ações coletivas para produtores na sua escala. Antônio acredita que poderia, através de um modelo 
de condomínio, compartilhar estrutura. Ele acredita também que os produtores precisam se unir para obter melhores condições de negociação com as usinas.

1) Papel das associações e cooperativas: Para Francisco, o papel das associações e cooperativas é importante no desenvolvimento gerencial dos produtores. No entanto, existem distinto níveis de serviço entre as associações. Algumas precisam ser mais atuantes. Ricardo e Antônio estão satisfeitos com a oferta de serviços de suas associações e percebem que os programas de desenvolvimento promovidos pelas organizações têm propiciado a participação e a troca de informações entre produtores.

\subsection{Análise das oportunidades identificadas}

Todas as oportunidades identificadas durante o mapeamento das experiências foram consolidadas no Quadro 15. As Personas, que tiveram cada oportunidade identificada no seu mapa, assim como os agentes do setor que podem participar da sua captura, foram identificadas.

Na sequência, é realizada uma discussão sobre como as oportunidades podem impactar as experiências das personas e sobre como os agentes do setor estão envolvidos 
Quadro 15 - Consolidação das oportunidades identificadas para cada Persona e identificação dos agentes do setor envolvidos

\begin{tabular}{|c|c|c|c|c|c|c|}
\hline \multirow[b]{2}{*}{ Processo } & \multirow[b]{2}{*}{ Atividade } & \multirow[b]{2}{*}{ Aspectos que podem gerar oportunidades para o setor } & \multicolumn{3}{|c|}{ Personas } & \multirow[b]{2}{*}{$\begin{array}{l}\text { Agentes do Setor } \\
\text { envolvidos }\end{array}$} \\
\hline & & & $\begin{array}{c}\text { Francisco } \\
\text { (Integral } \\
\text { Grande) }\end{array}$ & $\begin{array}{l}\text { Ricardo } \\
\text { (Intermed } \\
\text { Grande) }\end{array}$ & $\begin{array}{l}\text { Antônio } \\
\text { (Pequeno } \\
\text { Básico) }\end{array}$ & \\
\hline \multirow{5}{*}{$\begin{array}{l}\text { Planejamento } \\
\text { Agrícola }\end{array}$} & $\begin{array}{l}\text { Determinação da } \\
\text { vocação técnica } \\
\text { do ambiente }\end{array}$ & $\begin{array}{l}\text { Boa prática: Serviço Carta de Solos prestado pela Cooperativa, auxilia na } \\
\text { escolha de variedades mais responsivas. }\end{array}$ & $\mathbf{x}$ & $\mathbf{X}$ & $\mathbf{x}$ & $\begin{array}{l}\text { Associações } \\
\text { Cooperativas }\end{array}$ \\
\hline & $\begin{array}{l}\text { Seleção das } \\
\text { Variedades }\end{array}$ & $\begin{array}{l}\text { Dor: Insatisfação com o ritmo e com os custos das pesquisas para } \\
\text { desenvolvimento de variedades mais produtivas e resistentes. }\end{array}$ & $\mathbf{x}$ & $\mathbf{x}$ & & $\begin{array}{c}\text { Centros de } \\
\text { Pesquisa Varietal }\end{array}$ \\
\hline & Época da Colheita & $\begin{array}{l}\text { Dor: O baixo domínio sobre a determinação da época da colheita causa } \\
\text { diversas restrições operacionais. }\end{array}$ & & & $\mathbf{x}$ & Usinas \\
\hline & Época da Colheita & $\begin{array}{l}\text { Boa prática: Aumento do domínio das operações pelos produtores que } \\
\text { realizam atividades em conjunto através de um planejamento de plantio e } \\
\text { colheita integrado, via associação. }\end{array}$ & $\mathbf{x}$ & & & $\begin{array}{l}\text { Associações } \\
\text { Assessorias } \\
\text { Jurídicas }\end{array}$ \\
\hline & Época da Colheita & $\begin{array}{l}\text { Dor: Ineficiências operacionais das usinas geram atrasos na moagem, o } \\
\text { que impacta na cota diária de entrega, inviabilizando o planejamento da } \\
\text { colheita. }\end{array}$ & $\mathbf{X}$ & & & Usinas \\
\hline \multirow{2}{*}{$\begin{array}{l}\text { Organização de } \\
\text { Recursos }\end{array}$} & $\begin{array}{l}\text { Dimensionamento } \\
\text { de Equipamentos }\end{array}$ & $\begin{array}{l}\text { Possibilidade de Melhoria: Baixa escala inviabiliza a aquisição de } \\
\text { estrutura. O produtor vê a possibilidade de realização de operações em } \\
\text { conjunto, através de condomínio, podendo, desta forma, compartilhar } \\
\text { equipamentos. }\end{array}$ & & & $\mathbf{x}$ & $\begin{array}{l}\text { Associações } \\
\text { Consultorias } \\
\text { Assessorias } \\
\text { Jurídicas }\end{array}$ \\
\hline & $\begin{array}{l}\text { Dimensionamento } \\
\text { de Equipamentos }\end{array}$ & $\begin{array}{l}\text { Boa prática: O produtor tem estrutura completa, que é otimizada ao } \\
\text { realizar as operações de plantio e colheita para outros associados. Esta } \\
\text { prática ocorre dentro de um modelo de realização de operações coletivas, } \\
\text { organizado pela associação. }\end{array}$ & $\mathbf{X}$ & & & $\begin{array}{l}\text { Associações } \\
\text { Assessorias } \\
\text { Jurídicas }\end{array}$ \\
\hline
\end{tabular}




\begin{tabular}{|c|c|c|c|c|c|c|}
\hline \multirow[b]{2}{*}{ Processo } & \multirow[b]{2}{*}{ Atividade } & \multirow[b]{2}{*}{ Aspectos que podem gerar oportunidades para o setor } & \multicolumn{3}{|c|}{ Personas } & \multirow[b]{2}{*}{$\begin{array}{l}\text { Agentes do Setor } \\
\text { envolvidos }\end{array}$} \\
\hline & & & $\begin{array}{l}\text { Francisco } \\
\text { (Integral } \\
\text { Grande) }\end{array}$ & $\begin{array}{l}\text { Ricardo } \\
\text { (Intermed } \\
\text { Grande) }\end{array}$ & $\begin{array}{l}\text { Antônio } \\
\text { (Pequeno } \\
\text { Básico) }\end{array}$ & \\
\hline & $\begin{array}{l}\text { Dimensionamento } \\
\text { de Estrutura }\end{array}$ & $\begin{array}{l}\text { Possibilidade de Melhoria: Possibilidade de otimizar a estrutura de } \\
\text { equipamento, e funcionários, se os produtores através de aplicativo para } \\
\text { aluguel de equipamentos ou prestação de serviços para vizinhos. }\end{array}$ & & $\mathbf{x}$ & & $\begin{array}{l}\text { Plataformas de } \\
\text { compartilhamento } \\
\text { digital }\end{array}$ \\
\hline & $\begin{array}{l}\text { Planejamento e } \\
\text { compra de } \\
\text { insumos }\end{array}$ & $\begin{array}{l}\text { Boa prática: Apoio dos técnicos das cooperativas para o planejamento da } \\
\text { compra dos insumos e obtenção de melhores condiçôes de compra. }\end{array}$ & & $\mathbf{X}$ & $\mathbf{x}$ & Cooperativas \\
\hline & $\begin{array}{l}\text { Levantamento de } \\
\text { Recursos } \\
\text { Financeiros }\end{array}$ & $\begin{array}{l}\text { Boa prática: Cooperativas de crédito são boa alternativa para captar } \\
\text { recursos financeiros por oferecem taxas de juros diferenciadas, além } \\
\text { distribuir sobras. }\end{array}$ & & $\mathbf{x}$ & $\mathbf{x}$ & $\begin{array}{l}\text { Cooperativas de } \\
\text { Crédito }\end{array}$ \\
\hline & $\begin{array}{l}\text { Levantamento de } \\
\text { Recursos } \\
\text { Financeiros }\end{array}$ & $\begin{array}{l}\text { Dor: Exigência elevada de garantias para obtenção de crédito. Nas } \\
\text { cooperativas de crédito exigência de garantias é ainda maior. O ativo } \\
\text { biológico é pouco valorizado pelas instituições financeiras como garantia. }\end{array}$ & $\mathbf{X}$ & $\mathbf{x}$ & & $\begin{array}{l}\text { Instituições } \\
\text { Financeiras }\end{array}$ \\
\hline & $\begin{array}{l}\text { Levantamento de } \\
\text { Recursos } \\
\text { Financeiros }\end{array}$ & $\begin{array}{l}\text { Possibilidade de Melhoria: Fintechs, como opção para obter linhas de } \\
\text { crédito com taxas de juros mais atrativas e redução de garantias. }\end{array}$ & & & & Fintechs \\
\hline \multirow{2}{*}{$\begin{array}{l}\text { Produção de } \\
\text { Mudas }\end{array}$} & MPB e Meisoi & $\begin{array}{l}\text { Percepções distintas entre produtores: Alguns produtores têm a } \\
\text { percepção de que o custo das MPBs é muito elevado e que produzir a } \\
\text { própria muda é uma operação muito manual e complexa. Outros declaram } \\
\text { haver uma redução de custos significativa na implantação do canavial } \\
\text { quando associada à Meisoi, além dos ganhos de produtividade. }\end{array}$ & $\mathbf{x}$ & $\mathbf{x}$ & $\mathbf{x}$ & \multirow{2}{*}{$\begin{array}{l}\text { Associações } \\
\text { Cooperativas } \\
\text { Centros de } \\
\text { Pesquisas } \\
\text { Agronômicas } \\
\text { Startups }\end{array}$} \\
\hline & MPB e Meisoi & $\begin{array}{l}\text { Percepções distintas entre os produtores: Alguns produtores têm a } \\
\text { percepção de que a Meiosi não compensa em grande escala pelo risco de } \\
\text { contaminação com herbicidas da cultura de rotação, enquanto outros } \\
\text { acreditam que os cuidados adicionais compensam os benefícios do } \\
\text { método. }\end{array}$ & $\mathbf{x}$ & $\mathbf{x}$ & $\mathbf{x}$ & \\
\hline
\end{tabular}




\begin{tabular}{|c|c|c|c|c|c|c|}
\hline \multirow[b]{2}{*}{ Processo } & \multirow[b]{2}{*}{ Atividade } & \multirow[b]{2}{*}{ Aspectos que podem gerar oportunidades para o setor } & \multicolumn{3}{|c|}{ Personas } & \multirow[b]{2}{*}{$\begin{array}{l}\text { Agentes do Setor } \\
\text { envolvidos }\end{array}$} \\
\hline & & & $\begin{array}{c}\text { Francisco } \\
\text { (Integral } \\
\text { Grande) }\end{array}$ & $\begin{array}{l}\text { Ricardo } \\
\text { (Intermed } \\
\text { Grande) }\end{array}$ & $\begin{array}{l}\text { Antônio } \\
\text { (Pequeno } \\
\text { Básico) }\end{array}$ & \\
\hline & $\begin{array}{l}\text { Produção própria } \\
\text { de MPB }\end{array}$ & $\begin{array}{l}\text { Dor: Talvez não compense ter o próprio viveiro. Além da } \\
\text { operacionalização, para ser viável, é necessário comercializar as mudas. } \\
\text { Seria mais fácil comprar a muda pronta. }\end{array}$ & & $\mathbf{x}$ & & Viveiros \\
\hline & MPB & $\begin{array}{l}\text { Dor: Equipamento de plantio de MPB disponível no mercado é } \\
\text { insatisfatório, com baixo rendimento e baixa qualidade. }\end{array}$ & $\mathbf{x}$ & $\mathbf{x}$ & & $\begin{array}{l}\text { Fabricantes de } \\
\text { Equipamentos }\end{array}$ \\
\hline & MPB & $\begin{array}{l}\text { Boa Prática: Produtor adaptou semeadeira na oficina da sua fazenda para } \\
\text { plantar MPB e está satisfeito com o rendimento e a redução da necessidade } \\
\text { de mão de obra. }\end{array}$ & & $\mathbf{x}$ & & $\begin{array}{l}\text { Fabricantes de } \\
\text { Equipamentos }\end{array}$ \\
\hline \multirow{4}{*}{$\begin{array}{l}\text { Conservação e } \\
\text { Preparo do Solo }\end{array}$} & Sistematização & $\begin{array}{l}\text { Boa prática: A sistematização das áreas produtivas melhora a } \\
\text { conservação do solo e a eficiência de diversas operaçôes. Quando aliada à } \\
\text { utilização de piloto automático nas operaç̃̃es mecanizadas de plantio e } \\
\text { colheita, pode reduzir perdas e danos ao canavial. }\end{array}$ & $\mathbf{x}$ & $\mathbf{x}$ & $\mathbf{x}$ & $\begin{array}{c}\text { Serviços e } \\
\text { Tecnologias de } \\
\text { Sistematização e } \\
\text { Agricultura de } \\
\text { Precisão } \\
\text { Usinas }\end{array}$ \\
\hline & $\begin{array}{l}\text { Rotação de } \\
\text { Culturas }\end{array}$ & $\begin{array}{l}\text { Boa Prática: Adoção de rotação de culturas como prática conservacionista } \\
\text { do solo. }\end{array}$ & $\mathbf{x}$ & $\mathbf{x}$ & $\mathbf{x}$ & \\
\hline & $\begin{array}{l}\text { Rotação de } \\
\text { Culturas }\end{array}$ & $\begin{array}{l}\text { Boa Prática: Sistema de rotação prolongado, com três culturas, melhora a } \\
\text { estrutura do sol e reduz incidência de pragas, além de proporcionar a } \\
\text { diversificação de culturas e diluição dos riscos. }\end{array}$ & & $\mathbf{x}$ & & \\
\hline & Correção do Solo & $\begin{array}{l}\text { Possibilidade de Melhoria: Correção do solo através de agricultura de } \\
\text { precisão, fazendo uso de mapas aéreos de fertilidade e correção a taxas } \\
\text { varáveis. }\end{array}$ & & $\mathbf{x}$ & & $\begin{array}{l}\text { Produtores } \\
\text { Fornecedores de } \\
\text { Agricultura de } \\
\text { Precisão }\end{array}$ \\
\hline Plantio & Corte de Mudas & $\begin{array}{l}\text { Dor: As colhedoras existentes, mesmo com os kits para corte de muda, } \\
\text { danificam as gemas, causando perdas de mudas. }\end{array}$ & $\mathbf{x}$ & $\mathbf{x}$ & & $\begin{array}{l}\text { Fabricantes de } \\
\text { Equipamentos }\end{array}$ \\
\hline
\end{tabular}




\begin{tabular}{|c|c|c|c|c|c|c|}
\hline \multirow[b]{2}{*}{ Processo } & \multirow[b]{2}{*}{ Atividade } & \multirow[b]{2}{*}{ Aspectos que podem gerar oportunidades para o setor } & \multicolumn{3}{|c|}{ Personas } & \multirow[b]{2}{*}{$\begin{array}{l}\text { Agentes do Setor } \\
\text { envolvidos }\end{array}$} \\
\hline & & & $\begin{array}{l}\text { Francisco } \\
\text { (Integral } \\
\text { Grande) }\end{array}$ & $\begin{array}{l}\text { Ricardo } \\
\text { (Intermed } \\
\text { Grande) }\end{array}$ & $\begin{array}{l}\text { Antônio } \\
\text { (Pequeno } \\
\text { Básico) }\end{array}$ & \\
\hline & $\begin{array}{l}\text { Distribuição das } \\
\text { mudas }\end{array}$ & $\begin{array}{l}\text { Dor: A operação de distribuição nos sulcos não é homogênea e aumenta o } \\
\text { consumo de mudas. }\end{array}$ & $\mathbf{x}$ & $\mathbf{x}$ & & $\begin{array}{l}\text { Fabricantes de } \\
\text { Equipamentos }\end{array}$ \\
\hline & $\begin{array}{l}\text { Corte e Plantio } \\
\text { mecanizado }\end{array}$ & $\begin{array}{l}\text { Dor: A necessidade de cortar o tolete para a realização do plantio } \\
\text { mecanizado se torna uma porta de entrada para doenças. }\end{array}$ & $\mathbf{x}$ & & & $\begin{array}{l}\text { Fabricantes de } \\
\text { Equipamentos }\end{array}$ \\
\hline & $\begin{array}{l}\text { Distribuição das } \\
\text { mudas }\end{array}$ & $\begin{array}{l}\text { Dor: Mão de obra é mal instruída e mal preparada para fazer a distribuiç̧ão } \\
\text { de muda, principalmente, considerando os cuidados necessários } \\
\text { relacionados à Meiosi. }\end{array}$ & & $\mathbf{x}$ & & $\begin{array}{l}\text { Fabricantes de } \\
\text { Equipamentos }\end{array}$ \\
\hline \multirow{6}{*}{ Tratos Culturais } & $\begin{array}{l}\text { Controle } \\
\text { Fitossanitário }\end{array}$ & $\begin{array}{l}\text { Dor: Aumento da incidência de pragas e ervas daninhas após o fim das } \\
\text { queimadas elevou perdas e custos. }\end{array}$ & & $\mathbf{x}$ & & $\begin{array}{c}\text { Centros de } \\
\text { Pesquisas } \\
\text { agronômicas } \\
\text { Fabricantes de } \\
\text { Insumos }\end{array}$ \\
\hline & $\begin{array}{l}\text { Controle } \\
\text { Fitossanitário }\end{array}$ & $\begin{array}{l}\text { Boa Prática: Serviço da associação de regulagem e calibração dos } \\
\text { equipamentos utilizados nos tratos culturais. }\end{array}$ & & $\mathbf{x}$ & $\mathbf{x}$ & Associações \\
\hline & $\begin{array}{l}\text { Controle } \\
\text { Fitossanitário }\end{array}$ & $\begin{array}{l}\text { Boa Prática: Parceria com empresas fabricantes de insumos para } \\
\text { realização de experimentos representam oportunidades de inovação. }\end{array}$ & $\mathbf{x}$ & $\mathbf{x}$ & & $\begin{array}{l}\text { Fabricantes de } \\
\text { Insumos }\end{array}$ \\
\hline & $\begin{array}{l}\text { Controle } \\
\text { Fitossanitário }\end{array}$ & $\begin{array}{l}\text { Boa Prática: Assistência dos agrônomos da cooperativa para avaliar ervas } \\
\text { daninhas e recomendar herbicidas. }\end{array}$ & & & $\mathbf{x}$ & Cooperativas \\
\hline & $\begin{array}{l}\text { Controle } \\
\text { Fitossanitário }\end{array}$ & $\begin{array}{l}\text { Boa Prática: Serviço da associação de manejo integrado de pragas da } \\
\text { cana. }\end{array}$ & & & $\mathbf{x}$ & Associações \\
\hline & $\begin{array}{l}\text { Controle } \\
\text { Fitossanitário }\end{array}$ & $\begin{array}{l}\text { Boa Prática: Serviço da cooperativa de manejo integrado de pragas na } \\
\text { soja. }\end{array}$ & & $\mathbf{x}$ & & Cooperativas \\
\hline
\end{tabular}




\begin{tabular}{|c|c|c|c|c|c|c|}
\hline \multirow[b]{2}{*}{ Processo } & \multirow[b]{2}{*}{ Atividade } & \multirow[b]{2}{*}{ Aspectos que podem gerar oportunidades para o setor } & \multicolumn{3}{|c|}{ Personas } & \multirow[b]{2}{*}{$\begin{array}{l}\text { Agentes do Setor } \\
\text { envolvidos }\end{array}$} \\
\hline & & & $\begin{array}{c}\text { Francisco } \\
\text { (Integral } \\
\text { Grande) }\end{array}$ & $\begin{array}{l}\text { Ricardo } \\
\text { (Intermed } \\
\text { Grande) }\end{array}$ & $\begin{array}{l}\text { Antônio } \\
\text { (Pequeno } \\
\text { Básico) }\end{array}$ & \\
\hline & $\begin{array}{l}\text { Controle } \\
\text { Fitossanitário }\end{array}$ & $\begin{array}{l}\text { Boa prática: Agricultura de precisão. Serviço da cooperativa de } \\
\text { mapeamento de pragas com drones e planejamento de medidas de } \\
\text { controle. }\end{array}$ & $\mathbf{x}$ & & & $\begin{array}{l}\text { Cooperativas } \\
\text { Fornecedores de } \\
\text { agricultura de } \\
\text { precisão. }\end{array}$ \\
\hline \multirow{4}{*}{ CCT } & CCT & $\begin{array}{l}\text { Boa prática: O custo das operações de colheita e carregamento com } \\
\text { estrutura própria é inferior ao da usina. }\end{array}$ & $\mathbf{x}$ & & & $\begin{array}{l}\text { Associações } \\
\text { Usinas }\end{array}$ \\
\hline & Colheita & $\begin{array}{l}\text { Dor: Embora as colhedoras tenham alta tecnologia, as perdas são maiores } \\
\text { do que a colheita manual. As esteiras geram compactação do solo e há o } \\
\text { arranque de soqueira, o que acarreta perdas de produtividade nos próximos } \\
\text { anos. }\end{array}$ & $\mathbf{x}$ & & & $\begin{array}{l}\text { Fabricantes de } \\
\text { Equipamento }\end{array}$ \\
\hline & Colheita & $\begin{array}{l}\text { Dor: Má qualidade da colheita realizada pela usina. As equipes da usina } \\
\text { não cumprem os procedimentos padrão, o que acaba gerando desperdício } \\
\text { de matéria-prima e danos à plantação. }\end{array}$ & & $\mathbf{x}$ & $\mathbf{x}$ & Usinas \\
\hline & Colheita & $\begin{array}{l}\text { Boa prática: Serviço de avaliação e levantamento das perdas durante a } \\
\text { colheita realizada pela associação. }\end{array}$ & & $\mathbf{x}$ & $\mathbf{x}$ & Associações \\
\hline \multirow{3}{*}{ Comercialização } & $\begin{array}{l}\text { Contratos de } \\
\text { Fornecimento }\end{array}$ & $\begin{array}{l}\text { Dor: Produtores com menor volume de fornecimento, têm menor poder de } \\
\text { negociação. Obtém menores vantagens operacionais e financeiras (ex. } \\
\text { época da colheita, cotas de subprodutos, modelo de remuneração etc.). }\end{array}$ & & & $\mathbf{x}$ & $\begin{array}{c}\text { Usinas } \\
\text { Associações }\end{array}$ \\
\hline & $\begin{array}{l}\text { Contratos de } \\
\text { Fornecimento }\end{array}$ & $\begin{array}{l}\text { Boa Prática: Contrato de fornecimento de matéria-prima coletivo, } \\
\text { realizado via associação. Este modelo pode possibilitar aos pequenos e } \\
\text { médios produtores melhores condições de negociação. }\end{array}$ & $\mathbf{x}$ & & & Associações \\
\hline & $\begin{array}{l}\text { Modelo de } \\
\text { Precificação }\end{array}$ & $\begin{array}{l}\text { Dor: Modelo Consecana requer uma revisão. O modelo não acompanhou } \\
\text { o aumento dos custos de produção. Não reconhece parâmetros de } \\
\text { eficiência e qualidade, além das adequações às exigências do mercado. }\end{array}$ & $\mathbf{X}$ & $\mathbf{X}$ & $\mathbf{x}$ & $\begin{array}{c}\text { Consecana } \\
\text { (Orplana e Unica) }\end{array}$ \\
\hline
\end{tabular}




\begin{tabular}{|c|c|c|c|c|c|c|}
\hline \multirow[b]{2}{*}{ Processo } & \multirow[b]{2}{*}{ Atividade } & \multirow[b]{2}{*}{ Aspectos que podem gerar oportunidades para o setor } & \multicolumn{3}{|c|}{ Personas } & \multirow[b]{2}{*}{$\begin{array}{l}\text { Agentes do Setor } \\
\text { envolvidos }\end{array}$} \\
\hline & & & $\begin{array}{c}\text { Francisco } \\
\text { (Integral } \\
\text { Grande) }\end{array}$ & $\begin{array}{c}\text { Ricardo } \\
\text { (Intermed } \\
\text { Grande) }\end{array}$ & $\begin{array}{c}\text { Antônio } \\
\text { (Pequeno } \\
\text { Básico) }\end{array}$ & \\
\hline & $\begin{array}{l}\text { Modelo de } \\
\text { Precificação }\end{array}$ & $\begin{array}{l}\text { Dor: Não há valorização dos produtores independentes pelo risco } \\
\text { operacional assumido. }\end{array}$ & $\mathbf{x}$ & & & $\begin{array}{c}\text { Consecana } \\
\text { (Orplana e Unica) }\end{array}$ \\
\hline \multirow{4}{*}{$\begin{array}{l}\text { Planejamento e } \\
\text { Gestão }\end{array}$} & $\begin{array}{l}\text { Planejamento e } \\
\text { Gestão }\end{array}$ & $\begin{array}{l}\text { Boa Prática: Estrutura de Gestão Especializada. Processo de planejamento } \\
\text { e acompanhamento de resultados estruturado, envolvendo diversos } \\
\text { departamentos da empresa. }\end{array}$ & $\mathbf{x}$ & & & $\begin{array}{l}\text { Consultorias de } \\
\text { Gestão }\end{array}$ \\
\hline & $\begin{array}{l}\text { Gestão de } \\
\text { Resultados }\end{array}$ & $\begin{array}{l}\text { Boa Prática: Projeções econômicas ao longo dos cortes através de } \\
\text { software de gestão. }\end{array}$ & $\mathbf{x}$ & & & $\begin{array}{l}\text { Consultorias de } \\
\text { Gestão } \\
\text { Software de gestão }\end{array}$ \\
\hline & $\begin{array}{l}\text { Gestão de } \\
\text { Resultados }\end{array}$ & $\begin{array}{l}\text { Boa Prática: Gestão dos processos a partir do acompanhamento da } \\
\text { produtividade e dos custos por etapa de produção. }\end{array}$ & & $\mathbf{x}$ & & $\begin{array}{l}\text { Associações } \\
\text { Consultorias de } \\
\text { Gestão }\end{array}$ \\
\hline & $\begin{array}{l}\text { Gestão de } \\
\text { Resultados }\end{array}$ & $\begin{array}{l}\text { Boa Prática: Serviço prestado pela associação de orientação aos pequenos } \\
\text { produtores sobre gestão dos processos, a partir do acompanhamento da } \\
\text { produtividade e dos custos por etapa, fazendo uso da ferramenta Caderno } \\
\text { de Campo. }\end{array}$ & & & $\mathbf{x}$ & $\begin{array}{l}\text { Associações } \\
\text { Consultorias de } \\
\text { Gestão }\end{array}$ \\
\hline \multirow{2}{*}{$\begin{array}{l}\text { Adequação à } \\
\text { Legislação }\end{array}$} & $\begin{array}{l}\text { Adequação à } \\
\text { Legislação }\end{array}$ & $\begin{array}{l}\text { Boa Prática: Suporte jurídico e técnico da associação para a realização } \\
\text { das adequações socioambientais }\end{array}$ & $\mathbf{x}$ & $\mathbf{X}$ & $\mathbf{x}$ & $\begin{array}{l}\text { Associações } \\
\text { Governo } \\
\text { Consultorias }\end{array}$ \\
\hline & $\begin{array}{l}\text { Certificações } \\
\text { socioambientais }\end{array}$ & $\begin{array}{l}\text { Boa Prática: Programas de qualificação promovidos pela associação apoia } \\
\text { o produtor no processo de certificação socioambiental. }\end{array}$ & $\mathbf{x}$ & $\mathbf{x}$ & $\mathbf{x}$ & $\begin{array}{l}\text { Associações } \\
\text { Usinas } \\
\text { Auditorias de } \\
\text { certificação }\end{array}$ \\
\hline $\begin{array}{c}\text { Governança e } \\
\text { Sucessão }\end{array}$ & Sucessão & $\begin{array}{l}\text { Dor: Preocupação com a divisão das terras no processo de sucessão e a } \\
\text { descontinuidade do negócio. }\end{array}$ & & $\mathbf{x}$ & $\mathbf{x}$ & \\
\hline
\end{tabular}




\begin{tabular}{|c|c|c|c|c|c|c|}
\hline \multirow[b]{2}{*}{ Processo } & \multirow[b]{2}{*}{ Atividade } & \multirow[b]{2}{*}{ Aspectos que podem gerar oportunidades para o setor } & \multicolumn{3}{|c|}{ Personas } & \multirow[b]{2}{*}{$\begin{array}{l}\text { Agentes do Setor } \\
\text { envolvidos }\end{array}$} \\
\hline & & & $\begin{array}{l}\text { Francisco } \\
\text { (Integral } \\
\text { Grande) }\end{array}$ & $\begin{array}{c}\text { Ricardo } \\
\text { (Intermed } \\
\text { Grande) }\end{array}$ & $\begin{array}{l}\text { Antônio } \\
\text { (Pequeno } \\
\text { Básico) }\end{array}$ & \\
\hline & $\begin{array}{l}\text { Governança e } \\
\text { Sucessão }\end{array}$ & $\begin{array}{l}\text { Dor: Reconhecimento da necessidade de implantar um modelo de } \\
\text { governança e definir um processo de sucessão. }\end{array}$ & & $\mathbf{x}$ & & $\begin{array}{l}\text { Associações } \\
\text { Consultorias }\end{array}$ \\
\hline & $\begin{array}{l}\text { Governança e } \\
\text { Sucessão }\end{array}$ & $\begin{array}{l}\text { Boa Prática: Constituição de condomínio entre familiares, o que facilitou } \\
\text { a implementação de boas práticas de governança e um plano de sucessão. }\end{array}$ & $\mathbf{x}$ & & & \\
\hline \multirow{4}{*}{ Atuação integrada } & Atuação integrada & $\begin{array}{l}\text { Boa Prática: Oferta de serviços pelas associações, além de programas que } \\
\text { promovem troca de informação e participação dos produtores para } \\
\text { melhoria do setor }\end{array}$ & $\mathbf{x}$ & $\mathbf{x}$ & $\mathbf{x}$ & $\begin{array}{l}\text { Associações } \\
\text { Cooperativas }\end{array}$ \\
\hline & Atuação integrada & $\begin{array}{l}\text { Boa Prática: Os produtores podem se agrupar através de condomínios, } \\
\text { consórcios, ou através de suas associaçôes, buscando a formação de uma } \\
\text { estrutura operacional otimizada, implantação de um modelo de } \\
\text { governança, melhoria dos níveis de gestão e maior poder de negociação } \\
\text { com as usinas. }\end{array}$ & $\mathbf{x}$ & & & $\begin{array}{l}\text { Produtores } \\
\text { Associações } \\
\text { Empresas de } \\
\text { Consultoria e } \\
\text { Assessoria }\end{array}$ \\
\hline & Atuação integrada & $\begin{array}{l}\text { Possibilidade de Melhoria: Algumas organizações (associações e } \\
\text { cooperativas) estão mais à frente e outras mais atrás. Estas últimas } \\
\text { poderiam desempenhar um papel mais atuante no processo de } \\
\text { profissionalização do produtor. }\end{array}$ & $\mathbf{x}$ & & & $\begin{array}{l}\text { Associações } \\
\text { Cooperativas }\end{array}$ \\
\hline & Atuação integrada & $\begin{array}{l}\text { Boa Prática: Papel desempenhado por associações para auxiliar os } \\
\text { produtores na organização de atividades coletivas. }\end{array}$ & $\mathbf{x}$ & & & Associações \\
\hline
\end{tabular}

Fonte: Elaborado pelo autor 


\subsubsection{Oportunidades relacionadas ao Planejamento Agrícola}

\subsubsection{Serviço de carta de solos}

Este serviço, prestado pela cooperativa, é um aspecto positivo das experiências das três personas. O conhecimento dos diferentes ambientes produtivos permite a alocação das variedades de cana-de-açúcar que irão melhor se adaptar a ele, além de proporcionar informações para a escolha de práticas adequadas de manejo. Portanto, é uma referência de $\underline{\text { boa }}$ prática a ser adotada por outras cooperativas ou associações do setor.

8.3.1.2 Ritmo insatisfatório das pesquisas e desenvolvimento de novas variedades

Uma das dores na percepção dos produtores de grande porte, Francisco e Ricardo, está relacionada ao ritmo e ao custo insatisfatórios do desenvolvimento de variedades mais produtivas e resistentes. Eles avaliam que o desenvolvimento varietal da cultura da soja trouxe ganhos de produtividade muito maiores nos últimos anos do que o da cana-de-açúcar. Os agentes do setor envolvidos com esta atividade podem ser os centros de pesquisa, que desenvolvem programas de melhoramento genético.

\subsubsection{Aumento do domínio das operações através de ações coletivas}

Para Antônio, o produtor Básico / Pequeno, a época tardia da realização da colheita pela usina é um aspecto que limita o planejamento de outras atividades que poderiam lhe trazer ganhos de eficiência e produtividade. Um exemplo é a Meiosi, que tem restrição de época de plantio. Outra atividade que ele pode não ter tempo de realizar, caso a colheita atrase, é a rotação de cultura. Um outro fator relatado pelo produtor é que a qualidade da sua colheita, que pode ser impactada pelo período chuvoso do final da safra, principalmente quando esta atrasa. Outra limitação de gestão enfrentada por Antônio é que quando planeja a compra dos insumos e a sua cana ainda não foi colhida. Desta forma, ainda não recebeu pela entrega da matéria-prima, necessitando recorrer a financiamentos. Estas limitações podem evidenciar algumas das consequências ocasionadas pela dependência operacional do produtor em relação às usinas.

Já Ricardo, o produtor Intermediário / Grande, embora não tenha a atividade de planejamento da colheita sob seu domínio, conseguiu negociar com a usina a realização da colheita em época precoce e está satisfeito com este período, por dois motivos: Ele considera que o período é bom para a rebrota da planta devido à umidade que ainda permanece no solo. 
O outro fator é justamente o que afeta Antônio. Ele declara que durante reforma, com a colheita precoce, ele tem tempo para realizar outras atividades, como Meiosi e a rotação de culturas.

Francisco está satisfeito com o modelo de planejamento de plantio e colheita realizados pela associação de forma integrada para o grupo de produtores que realizam as atividades em conjunto. A colheita é planejada com o objetivo de cumprir a cota diária de entrega de matériaprima para a usina, buscando maximizar a produção de acordo com a época de maturação da cana de cada produtor. No entanto, a sua insatisfação está relacionada aos atrasos na moenda da usina, o que altera a quantidade diária acordada e impacta no planejamento original de colheita.

Desta forma, pode-se concluir que o planejamento da época da colheita é uma atividade crítica que, quando não está nas mãos do produtor, pode levar a uma série de restrições operacionais, representando uma $\underline{d o r}$ durante sua experiência. O caso de Antônio é o mais extremo, já que, entre todos, é o que tem menor poder de influência sobre a época da colheita. No entanto, mesmo Francisco, que tem a maioria das operações sobre o seu domínio, enfrenta limitações, já que fica à mercê de alterações no volume de sua cota diária de entrega pela usina.

Portanto, a oportunidade relacionada a esta etapa do processo envolve o aumento do domínio dos produtores sobre o planejamento da época da colheita, o que pode ser realizado através de ações coletivas. O modelo de realização de plantio e colheita de forma conjunta, através de um planejamento integrado realizado pela associação é uma boa prática relatada por Francisco. Embora existam outros modelos, um dos agentes do setor que pode apoiar os produtores nesta organização é a $\underline{\text { associação. }}$.

A usina é outro agente importante neste modelo, que ganha com o incremento de eficiência e de previsibilidade de produção dos produtores organizados, mas que precisa também ser eficiente para trabalhar em sinergia com a programação de entrega. ${ }^{26}$

\subsubsection{Oportunidades relacionadas à Organização de Recursos}

\subsubsection{Otimização da estrutura de equipamentos através de ações coletivas}

Um dos maiores desafios dos produtores para otimizar o retorno sobre o seu capital é o dimensionamento adequado de sua estrutura física. Com a intensificação da mecanização da produção da cultura de cana nos últimos anos, em função das restrições legais, tanto ambientais

\footnotetext{
${ }^{26}$ No capítulo 6.3.12 é relatado um caso em que fornecedores fizeram uso da associação para se organizarem e estabelecerem uma parceria com unidades industriais, gerando organização e previsibilidade de entrega.
} 
quanto trabalhistas, esta atividade se tornou ainda mais crítica. A baixa escala de produção é um fator limitante, que inviabiliza a aquisição de equipamentos. Por este motivo, muitos produtores acabam terceirizando diversas atividades.

Antônio, que é um produtor de pequeno porte, terceiriza a operação de plantio para empreiteiros e as atividades de CCT para a usina, justamente pela incapacidade de absorver uma estrutura maior. Ricardo, que é um produtor de grande porte, tem praticamente toda a estrutura própria, com exceção do CCT. Pelo fato de suas terras não estarem concentradas em uma mesma região, relata não valer a pena o investimento.

Antônio acredita que o modelo de organização entre produtores vizinhos, através de condomínios rurais, pode ser uma alternativa para compartilhamento de equipamentos.

Uma boa prática apontada por Francisco, que envolve o mesmo modelo descrito no tópico anterior, é a organização de produtores para realizarem operações em conjunto, otimizando assim a estrutura física. No caso de Francisco, um grupo de associados que possui a estrutura de plantio e colheita presta serviço para os demais, obedecendo a um planejamento integrado de atividades.

Os agentes do setor envolvidos na captura desta oportunidade são as associações, que podem auxiliar os produtores a se organizarem, e empresas de consultoria ou de assessoria jurídica, que podem auxiliar os produtores a encontrar outras formas para compartilhar estrutura, como através da formação de condomínios rurais.

8.3.2.2 Otimização da estrutura de equipamentos através plataformas de
compartilhamento

Outro modelo que pode ser uma alternativa para ajudar na otimização dos equipamentos agrícolas está relacionado à economia do compartilhamento. Ricardo, que busca dimensionar seus equipamentos de forma a trabalhar com uma estrutura mínima, necessária à realização de suas atividades, enxerga, como possibilidade de melhoria a utilização de plataformas de compartilhamento para alugar equipamentos ou prestar serviços para vizinhos, podendo aumentar, inclusive, a produtividade de seus funcionários.

\subsubsection{Suporte para planejamento e compra de insumos}

São poucos os produtores que contam com uma estrutura de gestão interna robusta o suficiente para realizar uma série de atividades de planejamento, que envolvem conhecimentos técnicos e de gestão especializados. Uma delas é a atividade de planejamento sobre quais 
insumos agrícolas serão utilizados para gerar os melhores resultados, envolvendo simultaneamente ganhos de produtividade, qualidade e custo. Desta forma, muitos produtores fazem uso dos serviços das cooperativas.

Francisco conta com este conhecimento técnico internalizado através de sua estrutura organizacional. Já Ricardo e Antônio utilizam o suporte técnico da cooperativa para planejar quais insumos serão utilizados, tendo em vista a melhor relação custo-benefício. Outro suporte complementar obtido através das cooperativas é a obtenção de melhores condições de compra, relacionadas a informações de mercado ou a condições de financiamento.

A oportunidade relacionada à atividade de planejamento e compra de insumos também está relacionada a uma boa prática que pode ser adotada por outras cooperativas.

\subsubsection{Alternativas modernas de obtenção de crédito}

Para os produtores, as cooperativas de crédito são uma boa alternativa para captar recursos financeiros por oferecem taxas de juros mais atrativas, além distribuir sobras. No entanto, para o levantamento de volumes elevados, as exigências de garantia são restritivas.

A exigência elevada de garantias para obtenção de crédito rural é um ponto destacado pelos produtores. Francisco relata que as instituições financeiras estão restringindo cada vez mais os volumes a serem tomados, exigindo garantias cada vez maiores. Ele declarou que o ativo biológico e as parcerias estabelecidas com usinas sólidas deveriam ser mais valorizados pelas instituições financeiras.

Uma nova modalidade de instituição financeira que está concedendo crédito para produtores rurais são as fintechs, que são empresas do setor financeiro baseadas em tecnologia. Estes modelos de negócio conectam investidores a tomadores, oferecendo taxas mais atrativas e exigindo menores garantias. Um dos fatores que propicia a exigência de menores garantias é a utilização de uma série abrangente de sistemas que analisam o perfil e o comportamento do tomador com maior acuracidade, reduzindo assim o risco para o investidor.

\subsubsection{Oportunidades relacionadas à Produção de Mudas}

8.3.3.1 Percepções distintas quanto ao sistema de Mudas pré-brotadas (MPB) associadas à MEIOSI

Foram identificadas percepções distintas entre os produtores quanto à relação custobenefício da utilização do sistema de produção de MPBs associadas à Meiosi, o que pode ser 
explicado pelo fato de que este sistema é relativamente recente e ainda está sofrendo uma série de aperfeiçoamentos tecnológicos.

Ricardo, o produtor Grande / Intermediário, produz suas próprias MPBs e faz a multiplicação através de Meiosi. Ele demonstra obter uma redução de custos considerável na implantação do canavial com a utilização de MPBs, além de obter ganhos de produtividade. Francisco, o produtor Integral / Grande, apesar de reconhecer a superioridade da muda em relação à qualidade e sanidade, considera o custo muito elevado. Ele acredita que valeria a pena se produzisse as próprias mudas. No entanto, considera a operação manual e complexa e aguarda uma evolução tecnológica para começar a adotar o sistema. Antônio, o produtor Básico / Pequeno, tomou conhecimento sobre os benefícios da MPB, porém também considera o custo da muda elevado.

Quanto à opção de produzir a própria muda ou comprar, Ricardo considera o custo da muda no mercado acessível. Considerando toda a operação em viveiro, que envolve estrutura e funcionário, além da necessidade de vender parte da produção para alcançar o ponto de equilíbrio, ele avalia que, dependendo do perfil do produtor, pode valer mais a pena comprar a muda do que produzir.

Quanto à Meiosi, também existem percepções distintas entre os produtores. Francisco tem a percepção de que a Meiosi não compensa em grande escala, principalmente pelo risco de contaminação com herbicidas da cultura de rotação. Ricardo, por sua vez, acredita que o cuidado adicional que o método demanda, compensa o retorno gerado com a redução dos custos das operações de carregamento e transporte. Já Antônio, que gostaria de adotar o sistema de Meiosi para obter esta redução de custos, se vê impedido devido à época tardia da realização da sua colheita.

Uma das $\underline{\text { dores }}$ identificadas durante a produção de mudas, está relacionada ao equipamento de plantio das MPBs. Francisco relata que um dos aspectos que o desencoraja a adotar as MPBs é o equipamento de plantio disponível no mercado, que não oferece uma boa qualidade nem rendimento satisfatório. Um fato interessante de ser apresentado neste ponto é a alternativa que Ricardo encontrou para lidar com esta limitação tecnológica do mercado. Ele conseguiu transformar, na própria oficina da fazenda, uma semeadeira em transplantadora de mudas, obtendo resultados positivos durante o plantio.

Para Ricardo, a produção de MPB com Meiosi demanda mais cuidado e mais trabalho. No entanto, ele declara que já existem alternativas, que ele próprio está utilizando para otimizar este processo. Uma delas é o gel de rega, que demanda menos irrigação, gerando ganhos de tempo, mão de obra e de consumo de diesel. 
Diante das percepções distintas dos produtores, as oportunidades podem estar relacionadas à disseminação do conhecimento e o esclarecimento sobre a relação custobenefício das práticas de produção de mudas. Considerando que é uma tecnologia recente e está em evolução, oportunidades podem estar relacionadas ao desenvolvimento de novas tecnologias que ajudem a otimizar o processo para reduzir custos e aumentar o rendimento. Diversos agentes do setor podem estar envolvidos neste desafio de inovação e propagação de conhecimento, tais como associações, cooperativas, viveiros, centros de pesquisas agronômicas, fabricantes de equipamentos e startups voltadas para o agronegócio.

\subsubsection{Oportunidades relacionadas à Conservação e Preparo do Solo}

Com relação à conservação e preparo do solo, algumas boas práticas podem servir de referência para outros produtores. Há também percepções de possibilidades de melhoria, através da adoção de novas tecnologias para otimização dos processos. Os fornecedores de serviços e tecnologias de sistematização e de agricultura de precisão são agentes do setor que podem estar envolvidos nestas oportunidades.

\subsubsection{Sistematização da área}

A sistematização é uma boa prática adotada pelas três personas que visa à conservação do solo e ao melhor rendimento das operações mecanizadas. Os produtores apontam para a redução do número de manobras, consumindo menos combustível, gerando menos desperdício de insumos e menor compactação do solo. Um projeto de sistematização aliado à utilização de piloto automático nas colhedoras, como apontado por Francisco, pode gerar significativo ganho na redução das perdas durante a colheita.

\subsubsection{Rotação de Cultura como prática conservacionista}

A rotação de cultura também é uma boa prática adotada pelas três personas, visando à conservação do solo. Ricardo adota um sistema de rotação prolongado. São 17 meses com três culturas diferentes. As vantagens apontadas por ele são a melhoria adicional da estrutura do solo, redução de pragas, além da diluição dos riscos de mercado com a diversificação de culturas. 


\subsubsection{Correção do solo com utilização de taxa variável}

Ricardo percebe uma possibilidade de melhoria na operação de correção do solo com obtenção de ganhos de produtividade e economia através da agricultura de precisão, fazendo uso de mapeamento aéreo de fertilidade com drones e correção a taxas variáveis.

\subsubsection{Oportunidades relacionadas ao Plantio}

\subsubsection{Insatisfação com o rendimento e a qualidade do plantio mecanizado}

Uma das maiores dores identificadas ao longo das experiências mapeadas está relacionada aos equipamentos de corte e plantio das mudas. Segundo Francisco, que realiza a operação mecanizada, as atividades relacionadas ao corte da muda e ao plantio são mais críticas do que a própria colheita mecanizada (CCT). Ricardo, embora considere a mão de obra mal qualificada, ainda prefere o plantio manual por considerar a operação mecanizada ineficiente.

Durante a colheita mecanizada, os produtores alegam que, mesmo com os kits para corte de mudas, a operação danifica muito a gema, ocasionando perdas. Para Ricardo, este ponto é ainda mais crítico com as mudas de Meiosi, que são mais sensíveis. Outro problema apontado é que a operação de distribuição nos sulcos não é homogênea, o que acaba aumentando o consumo de mudas. A necessidade de cortar o tolete para a realização do plantio mecanizado é outro fator que gera ineficiência, segundo Francisco, já propicia a ocorrência de doenças.

Estas dores, relacionadas ao plantio mecanizado de cana, podem representar oportunidades para os fabricantes de equipamentos.

\subsubsection{Oportunidades relacionadas aos Tratos Culturais}

Oportunidades para os agentes do setor, como centros de pesquisa, fabricantes de

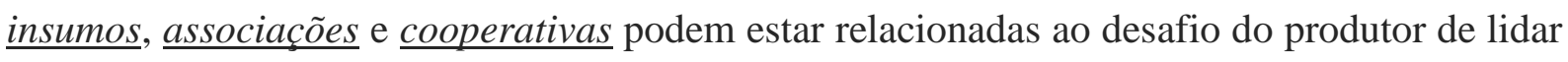
com a maior incidência de pragas e ervas daninhas após o fim das queimadas, e com o crescimento dos custos decorrentes deste cenário. Algumas boas práticas foram relatadas pelos produtores.

\subsubsection{Serviço de aferição e regulagem de equipamentos}

Uma boa prática apontada por Ricardo e Antônio é o serviço prestado pela associação de aferição e regulagem de equipamentos utilizados durante os tratos, tais como o destruidor de soqueira, bombas e tanques de pulverização. 


\subsubsection{Parcerias com fabricantes de insumos}

Os produtores Francisco e Ricardo cedem suas propriedades para fabricantes de insumos realizarem experimentos para o desenvolvimento de novos produtos e práticas de manejos. Eles consideram que esta é uma oportunidade para aprender com os especialistas, inovar e obter ganhos de produtividade.

\subsubsection{Assistência da cooperativa para controle de ervas daninhas}

Antônio conta com a assistência de agrônomos da cooperativa durante a avaliação de ervas daninhas e recomendação de herbicidas.

\subsubsection{Serviço de manejo integrado de pragas da cana}

Antônio utiliza o serviço da associação que envolve a inspeção de pragas e orientação sobre o uso de inseticidas. Ele está satisfeito com o serviço pois a informação sobre o índice de incidência de pragas, possibilita o uso racional de inseticidas.

\subsubsection{Serviço de manejo integrado de pragas da soja}

Ricardo utiliza o serviço de manejo integrado de pragas na cultura de soja, prestado pela cooperativa. Ele está extremamente satisfeito com os resultados, relatando que reduziu a zero o consumo de inseticidas.

\subsubsection{Mapeamento de pragas com drones}

Francisco aponta para uma possibilidade de melhoria no seu processo de controle de pragas, relacionada à agricultura de precisão. Ele está realizando uma parceria com uma das cooperativas para fazer um mapeamento de pragas com drones em área infestadas para, assim, definir medidas de controle pontuais.

\subsubsection{Oportunidades relacionadas ao CCT}

Durante as operações de corte carregamento e transporte da cana para usina, as grandes $\underline{\text { dores }}$ dos produtores são o custo da operação, as perdas durante a colheita e os danos causados ao canavial, reduzindo sua longevidade. 
8.3.7.1 Redução de custos com o domínio da atividade de colheita

A internalização das atividades de CCT possibilitou a Francisco um maior controle sobre as suas operações e redução de custos.

\subsubsection{Pontos de Melhoria nas Colhedoras}

Embora suas perdas tenham melhorado com medidas de sistematização e uso de piloto automático, considera que a operação mecanizada causa danos ao canavial. Embora considere as colhedoras de alta tecnologia, para ele existem pontos de melhoria. As suas principais dores estão relacionadas à compactação do solo e ao arranque de soqueira, o que acarreta perdas de produtividade nos próximos anos.

\subsubsection{Má qualidade do serviço realizado pela usina}

Um dos aspectos de maior insatisfação dos produtores que terceirizam a atividade de CCT para as usinas é a qualidade da colheita. Segundo os produtores, as equipes da usina não têm cuidado na hora da colheita, não cumprem os procedimentos, o que acaba gerando desperdício de matéria prima e danos ao solo e à plantação, levando à redução da produtividade e da longevidade do canavial. As equipes não cumprem os padrões de velocidade e regulagem das máquinas. Os principais aspectos levantados pelos produtores são o arranque da soqueira, pisoteio e perdas de cana.

\subsubsection{Serviço de avaliação de perdas durante a colheita}

A associação presta um serviço de avaliação da qualidade da colheita e elaboração de um relatório onde são apontadas as perdas e os danos causados ao solo e às soqueiras. Antônio e Ricardo relatam que este levantamento os auxilia no acompanhamento do serviço junto à equipe da usina. Eles relatam que precisam "ficar em cima" para garantir que o serviço seja adequado. O relatório pode ser utilizado também pelo produtor para obter um ressarcimento dos prejuízos junto à usina.

\subsubsection{Oportunidades relacionadas à Comercialização}

\subsubsection{Baixo poder de negociação dos pequenos fornecedores}

As três personas buscam estabelecer acordos através de contratos e relacionamentos de longo prazo com usinas sólidas, garantindo segurança e credibilidade no mercado. No entanto, 
uma das dores de Antônio, o pequeno produtor, é seu baixo poder de negociação. As usinas oferecem maiores vantagens na negociação àqueles que conseguem fornecer grandes volumes. Dentre as vantagens estão: a realização de um acordo sobre a época de realização da colheita; a obtenção de cotas de subprodutos e adequações no modelo de remuneração da cana.

Neste aspecto, oportunidades também podem estar relacionadas ao agrupamento dos produtores com menor escala através de ações coletivas. Uma das opções pode ser a realização de um contrato de fornecimento coletivo (pool de vendas). A organização dos produtores para realizarem as operações de plantio e colheita em conjunto com cota diária de entrega para as usinas, relatado por Francisco no tópico 8.2.1.3, foi viabilizado por um contrato coletivo via associação.

Portanto, a associação pode ser um agente capaz de conduzir este processo, fazendo a interface com a usina para obter maiores vantagens para os produtores pequenos.

\subsubsection{Modelo CONSECANA de precificação da cana}

O modelo de precificação da matéria-prima se apresenta como uma das maiores $\underline{\text { dores }}$ dos produtores. Segundo Francisco e Ricardo, a fórmula não acompanhou as mudanças decorridas no setor desde a sua implantação, tais como a mecanização, a sistematização do solo e novas técnicas de manejo que ocasionaram elevação dos custos de produção. Além disso, as três personas alegam que os seus esforços para se adequarem às exigências do mercado, buscando inclusive a obtenção de certificações socioambientais, não são reconhecidos pelo modelo atual. Francisco também alega que o modelo de remuneração não contempla um mecanismo de reconhecimento do risco assumido pelos produtores que assumem o domínio total de suas operações, principalmente o CCT.

As oportunidades relacionadas às percepções dos produtores sobre o modelo de precificação envolvem as instituições que representam os produtores (Orplana) e a indústria (Unica) no CONSECANA-SP. Como descrito no capítulo 5.5.2, o Conselho vinha trabalhando em uma proposta de revisão do modelo com o objetivo de incluir instrumentos para valorizar a eficiência produtiva e compartilhar valor. Em 25 de março de 2019 foi aprovado o termo de atualização do modelo CONSECANA-SP que determina novos parâmetros técnicos e diretrizes relacionadas ao pagamento da cana. O modelo atualizado passa a contemplar um prêmio associado à qualidade da matéria-prima, além de compartilhamento de valor por meio do reconhecimento de indutores de maior eficiência, como fidelidade contratual, adequação às normas regulamentadoras, remuneração pela cana certificada e cumprimento da programação da safra. 
Esta atualização visa uma maior integração entre o produtor de cana e a indústria compradora através da construção conjunta de valor via eficiência ${ }^{27}$.

\subsubsection{Oportunidades relacionadas ao Planejamento e Gestão de Resultados}

Boas Práticas relacionadas ao planejamento e controle de resultados são destacadas abaixo:

\subsubsection{Estrutura de Gestão Compartilhada}

Francisco relatou a existência de um processo de planejamento estruturado, envolvendo as diversas áreas da empresa. São realizadas projeções dos indicadores de custo e produtividade, assim como do fluxo de caixa ao longo dos cortes de cada talhão. Esta é uma prática que depende em parte da capacidade de investimento em uma estrutura de gestão profissionalizada e em parte pelo modelo de governança adotado.

Ricardo realiza o acompanhamento e toma decisões em cima da produtividade e dos custos por etapa de produção, avaliando o lucro e a remuneração do seu capital, a terra. Este é um nível de gestão que também pode ser usado como referência por outros produtores, em que o produtor tem seus processos estabelecidos e monitorados, com análises financeiras sobre o negócio, viabilizando tomadas de decisão, inclusive quanto à diversificação de culturas para obter melhores resultados.

Novamente, a oportunidade neste ponto também pode estar relacionada à união dos produtores para realização de ações coletivas. Aqueles produtores que não têm domínio sobre o conhecimento gerencial ou que não têm capacidade de investimento para incorporar o conhecimento de uma equipe especializada, ao se unirem, poderão compartilhar uma estrutura gerencial para realizar atividades como planejamento e controle de resultados.

\subsubsection{Caderno de Campo}

O caderno de campo é uma ferramenta de gestão, utilizada por Antônio, que permite o registro diário das atividades desempenhadas no campo, possibilitando uma maior visibilidade do negócio para tomadas de decisão através do acompanhamento da produtividade, custos por etapa de produção, receita e lucro. Este é um serviço prestado pela associação aos pequenos produtores que pode ser adotada por outras associações ou cooperativas.

\footnotetext{
${ }^{27}$ Informações fornecidas pela Gestão Executiva da Orplana.
} 


\subsubsection{Oportunidades relacionadas à Adequação à Legislação}

As oportunidades relacionadas às adequações à legislação são boas práticas que podem ser seguidas por outras associações.

\subsubsection{Suporte Jurídico das associações}

Ricardo e Antônio se sentem bem assessorados pelo departamento jurídico da associação. Consideram que a associação tem a capacidade de acompanhar e ser mais assertiva junto às questões legais do setor. Francisco tem a assessoria jurídica internalizada na sua estrutura organizacional.

8.3.10.2 Programas de qualificação para obtenção de certificação socioambiental

A associação tem um programa de qualificação e profissionalização dos produtores, aos quais assessora na realização das adequações socioambientais, além de dar orientação sobre práticas agrícolas e de gestão que podem elevar o seu nível de profissionalização.

\subsubsection{Oportunidades relacionadas à Governança e Sucessão}

8.3.11.1 Preocupação com a continuidade do negócio e dificuldade em tratar o tema com os familiares

Tanto Antônio, quanto Ricardo têm uma preocupação com a continuidade do negócio e sabem que não haverá sustentabilidade se a propriedade for dividida. Ricardo reconhece a necessidade de contratar uma consultoria para implantar um modelo de governança e definir um processo de sucessão, porém o tema é delicado e difícil de tratar entre os familiares. Já Antônio aposta no comprometimento da próxima geração de permanecer no negócio.

8.3.11.2 Constituição de condomínio familiar para facilitar a implementação de um modelo de governança e de um plano de sucessão

Segundo Francisco, a estruturação do negócio através da constituição de condomínio entre familiares possibilitou a implantação de um modelo de governança e de sucessão, que permite que o negócio continue avançando em grande escala, de forma independente das relações familiares. Com maior capacidade de investimento, foi possível investir em uma estrutura administrativa composta por profissionais especializados que permite a tomada de decisão com base em conhecimento especializado. 


\subsubsection{Oportunidades relacionadas à Atuação Integrada entre Produtores}

8.3.12.1 Realização de ações coletivas para aumentar a eficiência e sustentabilidade do negócio

Esta oportunidade já foi citada anteriormente como solução para algumas $\underline{\text { dores }}$ dos produtores. Neste tópico, todos estes aspectos serão consolidados para que se crie uma visão mais abrangente sobre a oportunidade.

Ao se organizarem para realizar atividades em conjunto, os produtores podem melhorar a sua eficiência em vários aspectos:

a) Dimensionamento de estrutura e mão de obra: Muitos produtores podem estar trabalhando com uma estrutura de equipamento superdimensionada por terem escala insuficiente para diluir seus custos. Outros optam pela terceirização da operação, o que pode levar a um menor domínio sobre as operações. Ao se unirem para realizar operações em conjunto, os produtores podem otimizar a estrutura física e funcionários.

b) Baixo domínio e controle sobre as operações: Quando algumas atividades são terceirizadas para a usina, o produtor perde parte do domínio e controle sobre suas operações, o que pode levar à perda de eficiência. Um exemplo é o caso de Antônio, que não pode planejar a Meiosi ou realizar a rotação de culturas porque fica à mercê do calendário de colheita da usina. A ineficiência da operação da colheita realizada pela usina, com ocorrência de maiores perdas e danos ao canavial, além de um custo operacional mais alto, é outra consequência da dependência do produtor. Ao se organizarem para realizar as atividades em conjunto, poderão compartilhar também uma estrutura de gestão profissionalizada, que possibilite a realização de atividades como planejamento e controle de processos de forma mais otimizada.

c) Baixo poder de negociação com as usinas: As usinas, no intuito de ganhar eficiência, priorizam contratos de grandes volumes. Desta forma, produtores com baixa capacidade produtiva não têm as mesmas vantagens durante as negociações de contratos. Ao realizarem um contrato coletivo de fornecimento de cana para a usina, os produtores podem começar a obter melhores condições de negociação.

d) Informalidade na gestão: Em muitos casos, os pequenos negócios familiares não conseguem estruturar uma gestão profissionalizada. É comum a inexistência de regras, funções e responsabilidades, o que pode levar à susceptibilidade do negócio a interferências de 
questões familiares. Ao se organizarem para produzir em grupo é necessário a instituição de um modelo de governança, com regras e normas que orientem que viabilizem uma gestão integrada das operações. Este é mais um ganho da união dos produtores.

\subsubsection{Apoio das associações na profissionalização dos produtores de cana}

Diversos serviços fornecidos pela associação e pelas cooperativas foram destacados pelos produtores e citados ao longo da narrativa das suas experiências. Estes serviços podem servir de referência como boas práticas para outras associações e cooperativas. É possível citar alguns exemplos, tais como a carta de solos, o serviço de avaliação de perdas na colheita, os programas de qualificação do produtor, assessoria jurídica, manejo integrado de pragas, caderno de campo etc.

Além dos serviços, os produtores também destacaram o papel das associações e cooperativas de promover a participação e a troca de conhecimentos e boas práticas entre os associados ou cooperados. Alguns exemplos citados são os núcleos de desenvolvimento organizados pela Cooperativa, o programa de qualificação da associação ou o grupo de whatsapp de manejo integrado de pragas na soja.

Além da prestação de serviços, algumas associações começaram a desempenhar um papel importante na profissionalização do produtor ao auxiliá-los na organização de atividades coletivas. Segundo os exemplos relatados neste estudo, a associação pode ajudar a estruturar o modelo de governança que irá orquestrar a operação coletiva, pode fazer a interface de negociação com a usina e pode realizar as atividades de planejamento da produção e controle dos processos de forma integrada. 


\section{CONCLUSÕES, IMPLICAÇÕES GERENCIAIS E LIMITAÇÕES DA PESQUISA}

Neste capítulo serão apresentadas as principais conclusões do estudo, o cumprimento dos objetivos propostos, bem como implicações gerenciais, limitações e sugestões de novas pesquisas.

\subsection{Conclusões}

O setor sucroenergético, apesar de estratégico para o país, vem enfrentando grandes desafios nos últimos anos. As unidades de produção industriais e agrícolas vêm sofrendo sérias dificuldades econômicas. O preço dos produtos, juntamente com o aumento dos custos de produção, decorrentes da necessidade de adequações ambientais e trabalhistas, são fatores que contribuíram para este cenário.

Por outro lado, a heterogeneidade do mundo dos produtores de cana-de-açúcar aponta para oportunidades de aumento da produtividade e eficiência do setor. Existem muitas diferenças e particularidades na forma como os produtores realizam as diversas operações no campo. A existência de diferentes níveis de gestão e profissionalização podem revelar caminhos para elevar a eficiência produtiva, tanto através da disseminação das boas práticas, quanto pelo aumento da sinergia entre produtores e entre agentes do setor.

Como parte do esforço da Orplana para capturar estas oportunidades, foi realizado um estudo a partir de uma base de custos de unidades produtivas com diferentes níveis de verticalização. As conclusões revelaram que quanto maior o controle e domínio sobre suas operações, menor será o custo final da cana entregue na esteira para a usina. Ou seja, o produtor independente consegue produzir com mais eficiência do que as usinas.

A abordagem de gestão da experiência na perspectiva do ecossistema do cliente se mostrou pertinente para complementar este estudo, considerando a intenção de conhecer de forma profunda os diversos aspectos que levam à profissionalização e ao incremento da eficiência dos produtores em seus diferentes níveis de domínio operacional.

Os mapas da experiência possibilitaram a criação de uma visão ampla e completa da experiência dos produtores ao longo dos seus processos. Três personas foram construídas para representar as experiências dos produtores nos níveis de verticalização Integral, Intermediário e Básico. A partir dos aspectos percebidos pelos produtos como relevantes para alcançar seus objetivos de negócio, representados através de uma curva com pontos altos e baixos, oportunidades para capturar valor para os produtores foram levantadas envolvendo diversos agentes do setor. 
As principais oportunidades identificadas neste estudo estão relacionadas a uma readequação dos sistemas produtivos para que os produtores ganhem eficiência e todo o setor seja beneficiado simultaneamente.

Neste sentido, um dos caminhos seria o aumento da autonomia operacional dos produtores. Alguns elementos identificados nesta pesquisa confirmam os resultados do estudo da Orplana de que o produtor perde eficiência ao terceirizar as suas operações. Uma evidência é a baixa qualidade e o alto custo do CCT realizados pela usina. Outra evidência está relacionada às limitações enfrentadas pelo produtor Básico por não ter domínio sobre o planejamento da época da colheita.

Considerando que a baixa escala de produção pode inviabilizar o movimento de verticalização, uma alternativa identificada é a realização de operações em conjunto, compartilhando, além dos equipamentos, funcionários, e uma estrutura de gestão profissionalizada. Dentre as alternativas de modelos de associação entre produtores estão as modalidades de condomínios e consórcios. As associações também podem desempenhar um papel importante neste processo, ajudando os produtores a se organizarem, estruturando um modelo de governança, realizando atividades de planejamento e gestão integrada ou ainda realizando a interface com a usina na negociação de um contrato coletivo de fornecimento.

As usinas também ganham com este aumento de autonomia e eficiência dos produtores. Ao aumentar a participação de cana fornecida por uma base de fornecedores capacitados, as usinas reduzem a imobilização de ativos, minimizam riscos e ganham eficiência. A atualização do modelo CONSECANA, em março de 2019, poderá contribuir com uma transferência gradual da atividade para os produtores. Ao criar mecanizamos de compartilhamento de valor que estimulam a busca por eficiência dos produtores, poderá contribuir para a criação de um ambiente de cooperação neste elo da cadeia e ganho de eficiência.

Diferenças nos níveis tecnológicos e gerenciais entre os produtores de cana também podem revelar oportunidades para elevar a eficiência no campo. Diante da recente transformação tecnológica que a cultura da cana vem sofrendo, os produtores vêm absorvendo as inovações para melhorar sua eficiência com diferentes velocidades.

Segundo as percepções dos produtores, algumas tecnologias estão trazendo bons resultados enquanto outras ainda não solucionaram suas dores. A mecanização do plantio é uma delas, já que as tecnologias disponíveis ainda não solucionaram as questões de qualidade e rendimento. $\mathrm{O}$ desenvolvimento varietal é outra dor dos produtores, que estão insatisfeitos com o ritmo e com os custos das pesquisas. 
Um aspecto que se destacou durante as investigações foram as percepções sobre os métodos de produção de mudas MPB e Meiosi. As percepções quanto à relação custo-benefício do uso das tecnologias são distintas entre os produtores. Embora alguns apontem para ganhos expressivos na redução de custo e aumento de produtividade, outros ainda acreditam que a tecnologia precisa evoluir.

A agricultura de precisão é um outro fator tecnológico que vem sendo encarado pelos produtores como uma promessa de ganhos. Piloto automático durante as operações mecanizadas já vem sendo utilizado. Outras inovações são encaradas como possibilidade de adoção futura, como é o caso da correção do solo à taxa variável e o mapeamento de fertilidade com drones.

Nos processos de gestão do negócio, a busca por capacitação técnica e gerencial também pode ser um caminho para elevar a eficiência. Investimentos em programas de capacitação, adoção de ferramentas gerenciais, adequações às exigências do mercado, além do esforço para obter certificações socioambientais foram boas práticas identificadas neste estudo. Parte deste movimento vem sendo fomentado pelas associações e cooperativas, que oferecem uma série de serviços que foram referenciados pelos produtores. Um ponto de dor para alguns produtores está relacionado à governança e sucessão. Os produtores reconhecem a importância do tema para a gestão profissional do negócio e para a garantia da continuidade para as próximas gerações, no entanto têm dificuldades de tratar a questão entre os familiares.

Em resumo, a maioria das oportunidades identificadas envolveu pontos de dor, percepções distintas entre produtores, boas práticas ou percepções de possibilidades de melhoria. Quanto às dores, sejam de natureza tecnológica, gerencial ou organizacional, são oportunidades que podem ser capturadas por diversos agentes do setor, como fabricantes, prestadores de serviços ou desenvolvedores de tecnologias. As boas práticas podem servir de referência para outros produtores, assim como para associações ou cooperativas. Possibilidades de melhoria foram outra fonte de oportunidade identificada neste estudo que revelam a percepção dos produtores sobre soluções disponíveis no mercado que poderiam auxiliá-lo no alcance de seus objetivos, mas que, por limitações econômicas ou organizacionais, ainda não foram adotadas.

\subsubsection{Alcance dos objetivos da pesquisa}

Conclui-se que o objetivo geral que orientou esta pesquisa foi alcançado. Através do mapeamento das experiências no nível do ecossistema de produtores de cana-de-açúcar, de diferentes portes e níveis de verticalização, foram identificadas oportunidades para que os 
agentes do setor, incluindo os próprios produtores, possam repensar seu posicionamento, suas ações e suas relações com os outros atores, para desenvolverem um ecossistema mais integrado e mais eficiente.

Para auxiliar no alcance do objetivo geral, objetivos específicos foram propostos, os quais, segundo análise abaixo, também foram alcançados.

- Foram identificadas técnicas e ferramentas na literatura que foram adaptadas e combinadas para fazer o mapeamento das experiências pertinentes aos processos dos produtores de cana-de-açúcar.

- Os processos do produtor foram mapeados através da identificação dos macroprocessos de Produção, Comercialização e Gestão e da sua decomposição em atividades.

- Em cada atividade, foi identificado o conjunto de decisões gerenciais tomadas, assim como os atores envolvidos e as percepções dos produtores sobre os serviços e tecnologias disponíveis no mercado;

- Ao analisar comparativamente as percepções dos produtores, foi possível identificar sob quais aspectos as suas experiências se diferenciam e quais são os padrões comuns entre eles, possibilitando a criação das personas;

- A partir dos pontos altos e baixos das experiências foram identificadas dores, boas práticas, possibilidades de melhorias, além de percepções distintas entre os produtores que levaram à identificação de oportunidades que podem ser capturadas pelos agentes.

\subsection{Contribuições da Pesquisa}

Esta pesquisa contribui para evolução do conhecimento sobre gestão da experiência do cliente por meio da revisão bibliográfica realizada, que proporcionou a organização do conteúdo através de uma visão abrangente das perspectivas de formação da experiência, relacionando-as aos métodos de gestão propostos.

Ao adaptar técnicas de diagnóstico da experiência do cliente ao contexto do produtor rural, esta pesquisa pode contribuir com um caso prático aplicado no contexto B2B. A maioria das pesquisas em experiência do cliente é conduzida em um contexto B2C (PALMER, 2013).

Existem diferenças quando comparamos a experiência do cliente em ambientes B2B e B2C. No contexto B2B é ainda mais relevante o alcance das metas do cliente do que os atributos dos produtos e serviços. O foco das empresas provedoras deve estar na aplicação de 
conhecimentos para entender, contribuir e monitorar o alcance dos objetivos específicos do cliente (LEMKE; CLARK; WILSON, 2011; ZOLKIEWSKI et al., 2017). Neste sentido, a escolha de uma ferramenta que permitisse mapear as experiências dos produtores na perspectiva do seu ecossistema foi pertinente. O mapa da experiência, diferente do mapa da jornada ou do blueprint de serviços, coloca a pessoa como um ator se comportando no seu contexto, enfatizando seus comportamentos e seus objetivos (KALBACH, 2017). Dentro desta perspectiva, a forma como foi estruturado o roteiro das entrevistas neste estudo, levou os entrevistados a se concentraram em relatar os fatores que causam maiores impactos nos seus resultados ao longo das suas experiências, sejam positivos ou negativos.

Outro aspecto relevante é que a qualidade da rede de serviços, ou seja, dos encontros com outros provedores e clientes, é considerada mais relevante para clientes B2B do que B2C (LEMKE; CLARK; WILSON, 2011; ZOLKIEWSKI et al., 2017). A identificação de diversos pontos críticos das experiências, envolvendo interações com múltplos atores do setor, evidencia a criticidade da rede de serviços para o sucesso no alcance dos objetivos de negócio.

Outro aspecto que pode contribuir com a literatura sobre mapeamento das experiências no contexto B2B está realacionada à fase de mapeamento dos processos do cliente realizada neste estudo. Segundo Kalbach (2017), o pesquisador pode optar por desenhar a sequência de fases e atividades realizadas pelo cliente antes ou após a coleta de informações nas entrevistas. Neste estudo, devido ao grande número de atividades e da complexidade envolvida nos processos do produtor de cana-de-açúcar, a realização preliminar desta etapa se mostrou crítica para que o tempo durante as entrevistas fosse bem aproveitado.

A construção de um roteiro de entrevista semi-estrturado, utilizando os processos mapeados como linha condutora das perguntas foi um fator importante durante a investigação. Esta técnica permitiu que todo o processo mapeado fosse coberto durante a entrevista, permitindo um certo grau de comparação entre os entrevistados. Para cada etapa e atividade foram realizadas as mesmas perguntas, evitando assim, que algum ponto caísse em esquecimento, já que o volume de aspectos a serem investigados era muito grande.

Outro ponto a ser levantado é que a etapa da pesquisa, em um ambiente B2B, demanda um esforço de entendimento técnico relacionado aos processos da empresa cliente (neste caso o produtor de cana), incluindo uma compreensão sobre as escolhas tecnológicas e serviços que o cliente tem à sua disposição. Assim, para o que o pesquisador esteja preparado para conduzir as entrevistas é conveniente o envolvimento de pessoas do setor durante o mapeamento preliminar dos processos. 


\subsubsection{Conribuições Gerenciais}

Além de contribuir com as oportunidades identificadas para os agentes do setor sucroenergético, este estudo contribui com empresas do agronegócio ao adaptar as técnicas de diagnóstico da experiência do cliente para o produtor rural.

Os mapas da experiência possibilitam a criação de uma visão ampla e contínua das experiências dos produtores, criando uma narrativa sobre sua trajetória e reunindo o conjunto de aspectos que são relevantes ao aproximá-lo ou afastá-lo dos seus resultados. Através de uma visão holística, fazendo uso das citações e de pontos altos e baixos ao longo de uma curva, a ferramenta se propõe a comunicar as emoções dos produtores, criando mais empatia com os demais agentes do setor.

Durante atividades de planejamento ou iniciativas orientadas à inovação, as empresas do setor podem utilizar os mapas fazendo uso de técnicas criativas e colaborativas para identificar oportunidades de melhoria e inovação.

Os mapas da experiência podem ser utilizados para mudar a perspectiva dos colaboradores, "de dentro para fora" para de "fora para dentro" (Kalbach, 2017). Portanto, mais do que se concentrar em criar experiências a partir da sua ótica de serviços, as empresas poderão utilizar os mapas para inovar a partir de uma visão criada pelas lentes do cliente, podendo até repensar seu posicionamento e seus relacionamento dentro do seu ecossistema.

\subsection{Limitações e recomendações para pesquisas futuras}

As limitações deste estudo estão relacionadas ao número de produtores que participaram da investigação e ao fato de a construção das experiências e identificação das oportunidades não terem envolvido e outros atores do setor através de uma dinâmica colaborativa.

Devido à base reduzida de entrevistados, aspectos das experiências dos produtores de outros perfis ou que vivem segundo outras realidades, ambientais ou mercadológicas, não foram capturadas neste estudo. Desta forma, as personas criadas neste trabalho não representam a totalidade da população da região escolhida.

Os aspectos de diferenciação identificados neste estudo podem ser utilizados durante a estruturação de um novo roteiro de entrevistas em futuras pesquisas com bases ampliadas, possibilitando um aprimoramento dos resultados, assim como a identificação de novas personas. Análises quantitativas podem complementar a pesquisa, como é o caso do levantamento que está sendo feito pelo projeto de segmentação da Orplana para identificar a representação dos diferentes níveis de verticalização na região centro-sul do Brasil. 
A fase de mapeamento das experiências também pode ser aprimorada. Através do uso de escalas é possível indicar a intensidade com que os aspectos são experimentados ao longo da curva da experiência ou a satisfação dos produtores ao longo dos pontos (Kalbach, 2017). Pode-se também combinar com informações de frequência com a qual atividades são realizadas ou tecnologias são experimentadas.

Outra limitação deste trabalho está relacionada à identificação de oportunidades para o setor. As oportunidades identificadas neste estudo foram construídas a partir das análises do pesquisador com base no que foi capturado nas entrevistas, apoiadas pelas fontes secundárias e por conversas de alinhamento com os gestores executivos das associações. A identificação de oportunidades de inovação pode ser potencializada ao reunir, através de seções de geração de ideias, colaboradores das associações e outros atores que participam do setor, aglutinando experiências e conhecimentos multidisciplinares. De acordo com o enfoque que se queira dar, estes atores podem ser colaboradores das associações, de empresas fornecedoras, e até envolver os próprios produtores (clientes), como a literatura sugere (YU; SANGIORGI, 2018; ZOMERDIJK; VOSS, 2011). 


\section{REFERÊNCIAS BIBLIOGRÁFICAS}

ADAlBERTON, E. M. Produção de Cana-de-Açúcar: Do Planejamento do Plantio à Colheita. 2012, 40 f. Trabalho de Conclusão (Título de Engenheiro Agrônomo). Centro de Ciências Agrárias da Universidade Federal de Santa Catarina, Florianópolis, 2012. Disponível em:https://repositorio.ufsc.br/bitstream/handle/123456789/100126/Est\%C3\%AAv\%C3\%A3o $\%$ 20Minatto\%20Alberton.pdf?sequence $=1 \&$ isAllowed $=\mathrm{y}$

ARANTES, J. Ambientes de Produção como ferramenta de produtividade para cana-de-açúcar. Nutrição de Safras. [s.1.]: 2014-2015 Mosaic Fertilizantes do Brasil, 2015. Disponível em: $<$ https://www.nutricaodesafras.com.br/ambientes-de-producao-como-ferramenta-deprodutividade-para-cana-de-acucar-ambicana>. Acesso em: 1 aug. 2019.

AS DIFERENÇAS entre empregados...: As principais diferenças entre os empregados urbano, doméstico e rural. Ribeirão Preto: 19 jun. 2017. SINDRP. Disponível em: <http://www.sindrp.com.br/2017/06/19/as-diferencas-entre-empregados/>. Acesso em: 21 apr. 2019.

BEAUCLAIR, E. G. F. Planejamento e estimativa na produção de cana. Revista. Visão Agrícola. Piracicaba: № 1 jan/jun 2004. Escola Superior de Agricultura Luiz de Queiroz, 2004. Disponível em: <https://www.esalq.usp.br/visaoagricola/sites/default/files/cana-producaovegetal01.pdf>. Acesso em: 29 dec. 2018.

BRAGA JUNIOR, R. L. C. et al. Censo Varietal IAC de cana-de-açúcar na região centro-sul do Brasil 2017/18. Boletim Técnico IAC 219. Campinas: Instituto Agronômico de Campinas: 2018. Disponível em:

<http://www.iac.sp.gov.br/publicacoes/publicacoes_online/pdf/btiac219.pdf >. Acesso em: 12 may. 2019. Acesso em: 20 dec. 2018.

BRASIL. Ministério da Agricultura Pecuária e Abastecimento. Associativismo rural. Brasília: 1 dez. 2016. Disponível em:

<http://www.agricultura.gov.br/assuntos/cooperativismo-associativismo/associativismorural>. Acesso em: 20 jan. 2019.

BRASIL. Ministério da Agricultura Pecuária e Abastecimento. A Agroenergia no Brasil. Brasília: [s.n]. Disponível em:

$<$ http://www.agricultura.gov.br/assuntos/sustentabilidade/agroenergia/agroenergia-nobrasill>. Acesso em: 19 mai. 2019.

BRASIL. MINISTÉRIO DO MEIO AMBIENTE. Cadastro Ambiental Rural. [Brasília]: [s.n.] Disponível em: http://www.mma.gov.br/desenvolvimento-rural/cadastro-ambientalrural.html Acesso em: 21 apr. 2019.

CARBONE, L. P. Clued In: How to Keep Customers Coming Back Again and Again. 3. ed. Upper Saddle River, FT Prentice Hall, 2004. 272 p.

CARTA de Solos é estratégia para evitar os riscos da concentração de variedades. Informativo Produtor. Guariba, Ano 2, No 14, Fevereiro/2017, Coplana, 2017. Disponível em: $<$ http://www.coplana.com:8090/wcoplana/wpcontent/uploads/2017/02/informativofevereio2017.pdf>. Acesso em: 3 jan. 2019. 
CARÙ, A.; COVA, B. Co-creating the collective service experience. Journal of Service Management, v. 26, n. 2, p. 276-294, 2015.

CASTRO, L. T. E; NEVES, M. F.; SCARE, R. F. Eficiência de representação das associações de produtores de cana-de-açúcar no Brasil. Organizações Rurais \& Agroindustriais, v. 17, n. 3, p. 383-397, 2015.

CAVERSAN, A. S. Modelo matemático para planejamento do plantio e colheita da canade-açúcar e da modelo matemático para planejamento do plantio e colheita da cana-deaçúcar e da cana-energia. 2017. 46 f.: Dissertação (Mestrado em Engenharia Elétrica) Universidade Estadual Paulista Júlio de Mesquita Filho, Baurú, 2017.

CHERUBIN, N. Muito além de garantir a sanidade das mudas e a alta taxa de multiplicação de variedades, a associação de MPB aos sistemas meiosi e cantosi tem trazido redução de custos de plantio e de mudas por hectare. Revista RPA news - cana \& indústria.[s.1.] Ano 16, N $^{\circ}$ 186, dezembro/janeiro 2016/17. Disponível em: <https://revistarpanews.com.br/ed/71edicao2015/edicao-186/1580-mpb-meiosi-ou-cantosi>. Acesso em: 5 may. 2019.

CHERUBIN, N. Sistematização e seus impactos na produção de cana-de-açúcar. RPA news cana \& indústria. [s.1.] Ano 18, $\mathrm{N}^{\circ}$ 201, Agosto de 2018. Disponível em: <https://revistarpanews.com.br/ed/6935-edicao-201>. Acesso em: 5 may. 2019.

CHESBROUGH, H. Open Services Innovation: Rethinking Your Business to Grow and Compete in a New Era. 1. ed. San Francisco, CA: Jossey-Bass, 2011. 241p.

COM ALUGUEL de máquinas entre proprietários, start-up leva economia compartilhada ao campo. Folha de São Paulo, São Paulo, 13.jun.2017.. Disponível em: <https://planodenegocios.blogfolha.uol.com.br/2017/06/13/com-aluguel-de-maquinas-entreproprietarios-start-up-leva-economia-compartilhada-ao-campo/>. Acesso em: 21 apr. 2019.

CONEJERO, M. A. et al. Arranjos Contratuais Complexos Na Transação De Cana À Usina De Áçucar e Alcool: Um Estudo de Caso no Centro-Sul do Brasil. In: XXXII EnAnpad, 2008, Rio de Janeiro. Anais...Rio de Janeiro, Anpad, 2008.

CONSÓRCIOS e Condomínios: Formação permite que pequenos e médios produtores de cana permaneçam na atividade. Revista Coplana. Guariba, Ano 9, No 71 Junho/Julho 2011. Disponível em:

<http://www.coplana.com:8090/wcoplana/wp-content/uploads/2016/05/Revista_71.pdf>.

COOPERATIVISMO Sustentável: Relação de Valor entre Associados. Sustentabilidade Boletim de Tendência [Florianópolis]: Fev 2016, SEBRAE-SC. Disponível em:

$<$ http://sustentabilidade.sebrae.com.br/Sustentabilidade/Para sua empresa/Publicações/2016_02_COOPERATIVISMO-SUSTENTAVEL.pdf>. Acesso em: 20 apr. 2019.

COSTA, E. A. M. Painel Jurídico Leis Aplicáveis ao Meio Rural Socicana. Guariba, Socicana, 2018. Disponível em: <http://socicana.com.br/2.0/wp-content/uploads/LeisAplicadas-a-produtores-Rurais-Certificações-site-revMARÇO2018.pdf >.

DONALD R. COOPER, P. S. S. Método de pesquisa em administração. 7. ed. Porto Alegre: Bookman, 2003. 640 p. 
ENTENDA A LEI. 12.651 de 25 de maio de 2012. Portal EMBRAPA. Brasília: [s.1.] Disponível em: <https://www.embrapa.br/en/codigo-florestal/entenda-o-codigo-florestal > Acesso em: 12 may. 2019.

FARINA, E.; GIANNETTI, F. Prefácio in: CASTRO, R. A. O. Contrato de fornecimento de cana-de-açúcar: Análise Jurídica e Econômica. [s.1.]: [2014] p.7-12. Disponível em: $<$ http://www.favaneves.org/wp-content/uploads/2018/03/Livro-Contrato-de-Cana-de-AcucarEditora-Atlas-2014.pdf>. Acesso em: 12 may. 2019.

FLICK, U. Desenho da pesquisa qualitativa. Porto Alegre: Artmed, 2009. 164 p.

FROW, P. et al. Value propositions: A service ecosystems perspective. Marketing Theory, v. 14, n. 3, p. 327-351, 2014.

FROW, P.; PAYNE, A. Towards the 'perfect' customer experience. Journal of Brand Management, v. 15, n. 2, p. 89-101, 2007.

GENTILE, C.; SPILLER, N.; NOCI, G. How to Sustain the Customer Experience: An Overview of Experience Components that Co-create Value With the Customer. European Management Journal, v. 25, n. 5, p. 395-410, 2007.

GIBBONS, S. UX Mapping Methods Compared: A cheat sheet. [s.1.]: 5 nov. 2017. N/N/g Nielsen Norman Group. Disponível em: <https://www.nngroup.com/articles/intelligentassistant-usability/?lm=ux-become-obsolete\&pt=youtubevideo>. Acesso em: 23 jan. 2019.

GONSALEZ, A. Economia colaborativa: dividir ao invés de acumular. EXAME Carreira Você S/A. 25 abr 2015. Disponível em: <https://exame.abril.com.br/carreira/economiacolaborativa-dividir-ao-inves-de-acumular/>. Acesso em: 12 may. 2019.

GRIOSOTTO, R. "Uberização" da economia avança sobre a roça - e adjacências. ÉPOCA NEGÓCIOS. [s.1.] 12 mar. 2017 Disponível em:

$<$ https://epocanegocios.globo.com/Tecnologia/noticia/2017/03/uberizacao-da-economiaavanca-sobre-roca-e-adjacencias.html>.

GRÖNROOS, C. Value co-creation in service logic: A critical analysis. Marketing Theory, v. 11, n. 3, p. 279-301, 2011.

GRÖNROOS, C.; VOIMA, P. Critical service logic: Making sense of value creation and cocreation. Journal of the Academy of Marketing Science, v. 41, n. 2, p. 133-150, 2013.

GUERRA, M. A união e, neste caso, a organização, fazem a força. Revista Canavieiros. Sertãozinho, Ano XI, Nº14, Abril 2018. Disponível em:

$<$ https://www.revistacanavieiros.com.br/imagens/pdf/c088c052fb52ad4fb6cd51be03dbb22f.p df>. Acesso em: 12 may. 2019.

HEINONEN, K. et al. A customer-dominant logic of service. Journal of Service Management, v. 21, n. 4, p. 531-548, 2010.

HEINONEN, K.; STRANDVIK, T. Customer-dominant logic: foundations and implications. Journal of Services Marketing, v. 29, n. 6/7, p. 472-484, 2015.

HEINONEN, K.; STRANDVIK, T.; VOIMA, P. Customer dominant value formation in 
service. European Business Review, v. 25, n. 2, p. 104-123, 2013.

HELKKULA, A.; KELLEHER, C.; PIHLSTRÖM, M. Characterizing Value as an Experience. Journal of Service Research, v. 15, n. 1, p. 59-75, 2012.

HOLBROOK, M. B.; HIRSCHMAN, E. C. The experiencial Aspects os consumption. The Journal of Consumer Research, v. 9, n. 2, p. 132-140, 1982.

INSTITUTO BRASILEIRO DE GEOGRAFIA E ESTATÍSTICA (IBGE). Censo Agro 2017 Resultados Preliminares. Rio de Janeiro: [s.n.] Disponível em:

<https://censos.ibge.gov.br/agro/2017/templates/censo_agro/resultadosagro/agricultura.html?1 ocalidade $=0 \&$ tema $=76434>$. Acesso em: 27 jan. 2019.

INSTITUTO DE ECONOMIA AGRÍCOLA DO ESTADO DE SÃO PAULO (IEA); UNIÃO DOS PRODUTORES DE BIOENERGIA (UDOP). Manual de Custos e Indicadores do Setor da Bioenergia. ed. 1, Araçatuba, 2017 . Disponível em:

<https://www.udop.com.br/download/pesquisas/manual_de_custos_e_indicadores.pdf >.

Acesso em: 12 may. 2019.

IVENS, C.; SHAW, J. Building Great Customer Experiences. 1. ed. New York, NY: Palgrave Macmillan, 2002. 224 p.

JAAKKOLA, E.; HELKKULA, A.; AARIKKA-STENROOS, L. Service experience cocreation: conceptualization, implications, and future research directions. Journal of Service Management, v. 26, n. 2, p. 182-205, 2015.

JOHNSTON, R.; KONG, X. The customer experience: a road-map for improvement. Managing Service Quality, v. 21, n. 1, p. 5-24, 2011.

KALBACH, J. Alignment Diagrams. 7 set. 2011. Boxes and Arrows. Disponível em: <http://boxesandarrows.com/alignment-diagrams/>. Acesso em: 27 apr. 2019.

KALBACH, J. Mapeamento de Experiências: Um guia para criar valor através por meio de jornadas, blueprints e diagramas. 1. ed. Rio de Janeiro: Alta Books, 2017. 362 p.

LANDELL, M. G. DE A. et al. Sistema de multiplicação de cana-de-açúcar com uso de mudas pré-brotadas (MPB), oriundas de gemas individualizadas. Campinas: Instituto Agronômico, 2012. 16p. (Documentos IAC, N. 109) online

LEMKE, F.; CLARK, M.; WILSON, H. Customer experience quality: An exploration in business and consumer contexts using repertory grid technique. Journal of the Academy of Marketing Science, v. 39, n. 6, p. 846-869, 2011.

LEMON, K. N.; VERHOEF, P. C. Understanding Customer Experience Throughout the Customer Journey. Journal of Marketing, v. 80, n. 6, p. 69-96, 2016.

LEONEL, I. M. B. Sucessão a empresa familiar, com ênfase na empresa rural. 2012. $60 \mathrm{f}$. Trabalho (Pós Graduação em Agronegócio) Departamento de Economia e Extensão Rural, Setor de Ciências Agrárias da Universidade Federal do Paraná. Curitiba.

LIPKIN, M. Customer experience formation in today's service landscape. Journal of Service Management, v. 27, n. 5, p. 678-703, 2016. 
LISBOA, A. Por que criar Persnas? 23 mar. 2017. UX Collective BR, Disponível em: $<$ https://brasil.uxdesign.cc/por-que-criar-personas-bc796a1ffc7e>. Acesso em:15 jan. 2019

LUSCH, R. F.; VARGO, S. L. Service-dominant logic: reactions, reflections and refinements. Marketing Theory, v. 6, n. 3, p. 281-288, 2006.

MATTAR, F. N. Pesquisa de Marketing v1. 6. ed. São Paulo: Atlas, 2005.

MCCOLL-KENNEDY, J. R.; CHEUNG, L.; FERRIER, E. Co-creating service experience practices. Journal of Service Management, v. 26, n. 2, 2015.

MELLO, F. O. T. DE; PAULILLO, L. F. Metamorfoses da rede de poder sucroalcooleira paulista e desafios da autogestão setorial. Agricultura em São Paulo, v. MATTAR, F. N.52, n. 1, p. 41-62, 2005.

MEYER, C.; SCHWAGER, A. Understanding Customer Experience. Harvard Business Review, v. 85, n. 2, p. 116-126, 2007.

MILLER, L. C. Parte 4 - Planejamento e operacionalização da colheita de cana-de-açucar In: Tecnologia Exploração e Manejo da Lavoura da Cana-de-açúcar. Araras: 28 maio 2006. Sigacana. Disponível em:

<http://www.sigacana.com.br/d_COLHEITA/4.PLANEJ_E_OPER_DA_COLHEITA_DE_C ANA_INDUSTRIAL_atualiz.htm>. Acesso em: 13 mar. 2019a.

MILLER, L. C. Parte 3 - Tratos culturais da cana-de-açúcar In: Tecnologia Exploração e Manejo da Lavoura da Cana-de-açúcar. Araras: [s.n.]. Sigacana. Disponível em: <www.sigacana.com.br/c_TRATOS_CULTURAIS\%5C3_Tratos_Culturais_da_Cana_de_Ac ucar.htm>. Acesso em: 6 apr. 2019b.

NEVES, M. F. et al. Mapeamento e quantificação da cadeia sucroenergética na safra 2013/2014. Ribeirão Preto: junho de 2014. Markestrat. Disponível em:

<https://udop.com.br/ebiblio/pagina/arquivos/30_05_14_mapeamento_quantificacao_setor_su croenergetico_safra_2013_14.pdf>.

OLIVEIRA, M. W. DE et al. Decomposição e liberação de nutrientes da palhada de cana-deaçúcar em campo. Pesquisa Agropecuária Brasileira, v. 34, n. 12, p. 2359-2362, 1999.

ORGANIZAÇÃO DE PLANTADORES DE CANA DA REGIÃO CENTRO-SUL DO BRASIL (ORPLANA). Sobre a Orplana. Ribeirão Preto Disponível em:

$<$ http://www.orplana.com.br/home/all-onepage-versions/quem-somos/>. Acesso em: 17 apr. 2019.

OS BENEFÍCIOS da aplicação de torta de filtro no canavial. Canaonline. Ribeirão Preto: 23 mar. 2017. Disponível em: <www.canaonline.com.br/conteudo/os-beneficios-da-aplicacao-detorta-de-filtro-no-canavial.html>. Acesso em: 31 mar. 2019.

PALMER, A. Customer experience management: a critical review of an emerging idea. Journal of Services Marketing, v. 24, n. 3, p. 17, 2013.

PATRICIO, L. et al. Multilevel Service Design: From Customer Value Constellation to Service Experience Blueprinting. Journal of Service Research, v. 14, n. 2, p. 180-200, 2011. 
PEDROSO JÚNIOR, R. Arranjos Institucionais aa Agricultura Brasileira: Um estudo sobre o uso de contratos no sistema agroindustrial sucroalcooleiro da região centro-sul. 2008. $209 \mathrm{f}$.: Dissertação (Mestre em Administração) - Departamento de Administração da Faculdade de Economia, Administração e Contabilidade da Universidade de São Paulo, São Paulo, 2008.

PINE II, B. J.; GILMORE, J. Integrating experiences into your business model: five approaches. Strategy \& Leadership, v. 44, n. 1, p. 3-10, 2016.

PINE, J. B.; GILMORE, J. B. The Experience Economy. Boston: Harvard Business School Press, 1999.

PONCIANO, N. J. et al. Avaliação econômica do cultivo de cana no sistema convencional e no sistema Meiosi. In: Congresso SOBER, 48, Campo Grande. Anais...Campo Grande: Sociedade Brasileira de Economia Administração e Sociologia Rural, 2010

PRAHALAD, C. K.; RAMASWAMY, V. Co-creation experiences: The next practice in value creation. Journal of Interactive Marketing, v. 18, n. 3, p. 5-14, 2004a.

PRAHALAD, C. K.; RAMASWAMY, V. The New Frontier of Experience Innovation. MIT Sloan Management Review, v. 45, n. 2, p. 26-32, 2004b.

PUCCINELLI, N. M. et al. Customer Experience Management in Retailing: Understanding the Buying Process. Journal of Retailing, v. 85, n. 1, p. 15-30, 2009.

RAWSON, A. et al. The Truth About Customer Experience: Interaction. Harvard Business Review, v. 91, n. 11, p. 26, 2013.

RÉVILLION, A. S. P. A Utilização de Pesquisas Exploratórias na Área de Marketing. Revista Interdisciplinar de Marketing, v. 2, n. 2, p. 21-37, 2003.

RISDON, C. The Anatomy of an Experience [s.1.] 30 nov. 2011. Map Adaptative Path Disponível em: <http://adaptivepath.org/ideas/the-anatomy-of-an-experience-map/>. Acesso em: 29 jan. 2019.

RONQUIM, C. C. Queimada na colheita da cana-de-açúcar: Impactos ambientais, sociais e econômicos. Embrapa Monitoramento por Satélite. Campinas: Embrapa Monitoramento por Satélite, 2010. Disponível em:

<https://ainfo.cnptia.embrapa.br/digital/bitstream/item/27830/1/Doc-77.pdf>. Acesso em: 13 may. 2019.

ROSSETTO, R. Maturação. Árvore do Conhecimento Cana-de-Açúcar. Brasília: 24 abr. 2009. Agência Embrapa de Informação Tecnológica (Ageitec). Disponível em:

<www.agencia.cnptia.embrapa.br/gestor/cana-de-

acucar/arvore/CONTAG01_90_22122006154841.html 1/2>. Acesso em: 6 apr. 2019.

ROSSETTO, R.; SANTIAGO, A. D. Plantio da cana-de-açúcar. Árvore do Conhecimento Cana-de-Açúcar. Brasília: 24 abr. 2009. Agência Embrapa de Informação Tecnológica (Ageitec). Disponível em: <https://www.agencia.cnptia.embrapa.br/gestor/cana-deacucar/arvore/CONTAG01_33_711200516717.html>. Acesso em: 31 mar. 2018a.

ROSSETTO, R.; SAnTIAGO, A. D. Cultivo mínimo. Árvore do Conhecimento Cana-deAçúcar. Brasília: 24 abr. 2009. Agência Embrapa de Informação Tecnológica (Ageitec). 
Disponível em:

$<$ http://www.agencia.cnptia.embrapa.br/gestor/cana-de-

acucar/arvore/CONTAG01_85_22122006154841.html>. Acesso em: 31 mar. 2019b.

ROSSETTO, R.; SANTIAGO, A. D. A importância das plantas sadias. Árvore do Conhecimento Cana-de-Açúcar. Brasília: 24 abr. 2009. Agência Embrapa de Informação Tecnológica (Ageitec). Disponível em: <www.agencia.cnptia.embrapa.br/gestor/cana-deacucar/arvore/CONTAG01_40_711200516717.html>.

RUIZ, L. Meiosi x Cantosi: Qual omelhor sistema de Plantio? Ribeirão Preto: 26 abr. 2018 Disponível em: <http://www.canaonline.com.br/conteudo/meiosi-X-cantosi-qual-omelhorsistema-de-plantio.html>. Acesso em: 12 dec. 2018.

SANTIAGO, A. D.; ROSSETTO, R. Preparo do Solo. Árvore do Conhecimento Cana-deAçúcar. Brasília: 24 abr. 2009. Agência Embrapa de Informação Tecnológica (Ageitec). Disponível em: <http://www.agencia.cnptia.embrapa.br/gestor/cana-deacucar/arvore/CONTAG01_20_711200516716.html>.

SANTIAGO, A. D.; ROSSETTO, R. Preparo Convencional. Árvore do Conhecimento Canade-Açúcar. Brasília: 24 abr. 2009. Agência Embrapa de Informação Tecnológica (Ageitec). Disponível em: <http://www.agencia.cnptia.embrapa.br/gestor/cana-deacucar/arvore/CONTAG01_84_22122006154841.html>.

SAntiago, A. D.; ROSSETTO, R. Plantio Manual. Árvore do Conhecimento Cana-deAçúcar. Brasília: 24 abr. 2009. Agência Embrapa de Informação Tecnológica (Ageitec). Disponível em: <http://www.agencia.cnptia.embrapa.br/gestor/cana-deacucar/arvore/CONTAG01_2_22122006154840.html>.

SÃO PAULO (Estado). Secretaria de Infraestrutura e Meio Ambiente do Estado de São Paulo. Etanol Verde. São Paulo: [2018] Disponível em: $<$ https://www.infraestruturameioambiente.sp.gov.br/etanolverde/>. Acesso em: 21 apr. 2019.

SÃO PAUlO (Estado). Sistema Ambiental Paulista. São Paulo normatiza Programa de Regularização Ambiental. São Paulo: [s.n.] Disponível em: $<$ http://www2.ambiente.sp.gov.br/sao-paulo-regulamenta-programa-de-regularizacaoambiental/>. Acesso em: 21 apr. 2019.

SCARPARI, M. S. Modelos para a previsão da produtividade da cana-de-açúcar (saccharum spp.) através de parâmetros climáticos. 2002. 79 f.: Dissertação (Mestre em Agronomia) - Escola Superior de Agricultura Luiz de Queiroz, Universidade de São Paulo, Piracicaba, 2002.

SCHMITT, B. H. Gestão da Experiência do Cliente: Uma Revolução no Relacionamento com os Consumidores. 1. ed. Porto Alegre: Artmed Editora S.A., 2004. 184 p.

SILVA, A. et al. Planejamento otimizado para colheita de cana-de-açúcar de uma usina sucroalcooleira. In: XLIII Simpósio Brasileiro de PESQUISA OPERACIONAL. Anais...Ubatuba: Sociedade Brasileira de Pesquisa Operacional (SOBRAPO), 2011

SILVA, F. L. DA. Diretrizes para certificação socioambiental de produtores de cana-deaçúcar a partir da experiência do setor florestal. 2010. 111 f.: Tese (Doctor Scientiae) Programa de Pós Graduação em Ciência Florestal da Universidade Federal de Viçosa, Viçosa, 
MG, 2010.

SILVA, J. C. Tecnologias para produção de mudas de cana- de-açúcar. 2017. 76 f.: Dissertação (Mestre em Ciências Agrárias)Programa de Pós-graduação em Ciências Agrárias Agronomia do Instituto Federal de Educação, Ciência e Tecnologia Goiano, Rio Verde, 2017.

SOARES, M. B. B. Sistemas de cultivo em área de reforma de cana-de-açúcar e a sucessão de culturas na composição da comunidade infestante. 2014. 63 f.: Dissertação (Mestre em Agronomia) - Faculdade de Ciências Agrárias e Veterinárias da Universidade Estadual Paulista, Jaboticabal, 2014.

TOWNSEND, C. R. Recomendações técnicas para o cultivo da cana-de-açúcar forrageira em Rondônia. Porto Velho: Nov. 2000. Agência Embrapa de Informação Tecnológica (Ageitec). Disponível em:

<http://www.agencia.cnptia.embrapa.br/Repositorio/Rt_21_000fkv0qne702wyiv80sq98yqvm h7ouy.PDF $>$.

TRENTINI, F.; DARIO, B. B. Contrato de fornecimento de cana-de-açúcar: importância, classificação e implicações jurídicas In: CASTRO, R. A. O. O Contrato de Fornecimento de Cana-de-açúcar: Análise Jurídica e Econômica. [s.1.]: [2014] p.53-77. Disponível em: $<$ http://www.favaneves.org/wp-content/uploads/2018/03/Livro-Contrato-de-Cana-de-AcucarEditora-Atlas-2014.pdf>. Acesso em: 21 apr. 2019.

UNIÃO DA INDUSTRIA DE CANA-DE-AÇÚCAR (UNICA). Fotografia do setor sucroenergético no brasil e os benefícios econômicos, ambientais e sociais gerados. São Paulo. 2018. Disponível em: http://www.unica.com.br/download.php?idSecao=17\&id=35831777 Acesso em: 21 apr. 2019.

Trischler, j.; zehrer, a. Service design: suggesting a qualitative multistep approach for analyzing and examining theme park experiences. Journal of Vacation Marketing, v. 18, n. 1, p. 57-71, 2012.

VALERIO, M. P. Condomínios e Consórcios Agrários. [s.n.]: maio 2012. Disponível em: $<$ https://consultorianoagronegocio.wordpress.com/2012/05/21/condominios-e-consorciosagrarios/>. Acesso em: 20 apr. 2019.

VARGO, S. L.; LUSCH, R. F. Evolving to a New Dominant Logic for Marketing. Journal of Marketing, v. 68, n. 1, p. 1-17, 2004.

VARGO, S. L.; LUSCH, R. F. Service-dominant logic: Continuing the evolution. Journal of the Academy of Marketing Science, v. 36, n. 1, p. 1-10, 2008.

VEIGA FILHO, A. D. A. Quando Reformar um Canavial? São Paulo: 11 mar. 2002. Instituto de Economia Agrícola (IEA). Disponível em:

<http://www.iea.sp.gov.br/out/LerTexto.php?codTexto=110>. Acesso em: 21 apr. 2019.

VEIGA, K. L. A.; ZANetTI, M. A. Z.; FAgGiOn, P. L. Fundamentos da Topografia. Curitiba: 2012. Universidade Federal do Paraná Disponível em:

<http://www.cartografica.ufpr.br/docs/topo2/apos_topo.pdf> Acesso em: 20 jan. 2019.

VERHOEF, P. C. et al. Customer Experience Creation: Determinants, Dynamics and Management Strategies. Journal of Retailing, v. 85, n. 1, p. 31-41, 2009. 
YU, E.; SANGIORGI, D. Service Design as an Approach to Implement the Value Cocreation Perspective in New Service Development. Journal of Service Research, v. 21, n. 1, p. 40-58, 2018.

ZOLKIEWSKI, J. et al. Strategic B2B customer experience management: the importance of outcomes-based measures. Journal of Services Marketing, v. 31, n. 2, p. 172-184, 2017.

ZOMERDIJK, L. G.; VOSS, C. A. NSD Processes and practices in experimental services_Zomerdijk\&Voss.pdf. Journal of Product Innovation Management, p. 63-80, 2011. 


\section{APÊNDICE A - Termo de confidencialidade}

Antes de iniciar as entrevistas foi solicitado o consentimento do entrevistado para a realização da gravação com o comprometimento da manutenção da confidencialidade mediante a assinatura do seguinte termo:

Título do projeto: Diagnóstico da experiência de produtores de cana-de-açúcar do interior de São Paulo na perspectiva do ecossistema do cliente

Pesquisador responsável: Larissa Mayer Munhos

Departamento: Administração/FEARP/USP

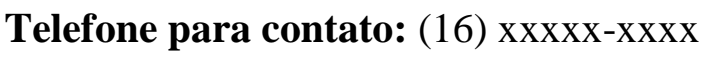

Nome do Entrevistado:

Eu, Larissa Mayer Munhos, abaixo assinado, comprometo-me a preservar a privacidade e o anonimato dos sujeitos que irão fornecer dados e informações obtidas através de documentos ou gravações durante as atividades desenvolvidas no projeto de pesquisa "Diagnóstico da experiência de produtores de cana-de-açúcar do interior de São Paulo na perspectiva do ecossistema do cliente", tendo como orientador o Professor Marcos Fava Neves, vinculado ao Departamento de Administração da Faculdade de Economia, Administração e Contabilidade de Ribeirão Preto. Concordo, igualmente, que estas informações serão utilizadas única e exclusivamente para execução do presente projeto. As informações somente poderão ser divulgadas preservando o anonimato dos sujeitos e serão mantidas em poder do responsável pela pesquisa, por um período de 5 anos. Após este período, os dados serão destruídos.

Ribeirão Preto, de de 2018

Larissa Mayer Munhos

Entrevistado 


\section{APÊNDICE B - Roteiro das Entrevistas}

\section{Introdução:}

Obrigada mais uma vez pela sua participação. O Objetivo desta pesquisa é compreender a experiência do produtor de cana-de-açúcar ao longo de todos os seus processos, incluindo produção, comercialização e gestão.

A partir da perspectiva do produtor, esta pesquisa tem o objetivo de compreender quais são seus principais desafios para alcançar seus objetivos de negócio. Em cada etapa do processo, a intenção é coletar as suas percepções sobre os serviços e tecnologias disponíveis para realizar suas atividades, bem como as suas interações com os diversos agentes do setor.

A partir deste levantamento, esta pesquisa visa criar uma visão ampla e integrada sobre a experiência do produtor de cana-de-açúcar, possibilitando a identificação de oportunidades para que os agentes do setor, incluindo os próprios produtores, possam repensar suas ofertas e suas interação dentro deste ecossistema no qual todos estão envolvidos.

\section{Bloco 1. Perguntas Iniciais:}

Inicialmente serão realizadas algumas perguntas para levantar informações básicas sobre a propriedade e o negócio, $O$ objetivo é identificar características que possam afetar as experiências, bem como usá-las para fazer comparações entre diferentes perfis de produtores.

Com o objetivo de poder comparar as percepções coletadas e identificar características que possam afetar as experiências, este bloco visa realizar um levantamento sobre algumas informações básicas sobre a propriedade e o negócio:

- Qual é a localização da (s) sua (s) propriedade (s)?

- Quantos hectares elas têm?

- Qual é a sua Produtividade média na última safra?

- Você tereceiriza alguma atividade?

- Para qual(is) usina(s) você fornece?

- Você é o principal responsável pela gestão da sua propriedade ou você conta com o apoio de outros gestores ou técnicos para auxiliar na tomada de decisão?

\section{Bloco 2. Objetivos:}

- Quais são seus principais objetivos como produtor de cana-de-açúcar? 


\section{Bloco 3. Levantamento das percepções dos produtores ao longo de seus processos:}

Ao longo de cada etapa do processo, serâo realizadas basicamente as mesmas perguntas. Vou buscar compreender seus desafios, suas percepções sobre serviços e tecnologias disponíveis no mercado, bem como suas interações com os divresos agentes do setor. No entanto, a conversa poderá fluir para aspectos que você considere pertinente pontuar. Fique a vontade para pontuar, caso não faça parte do roteiro.
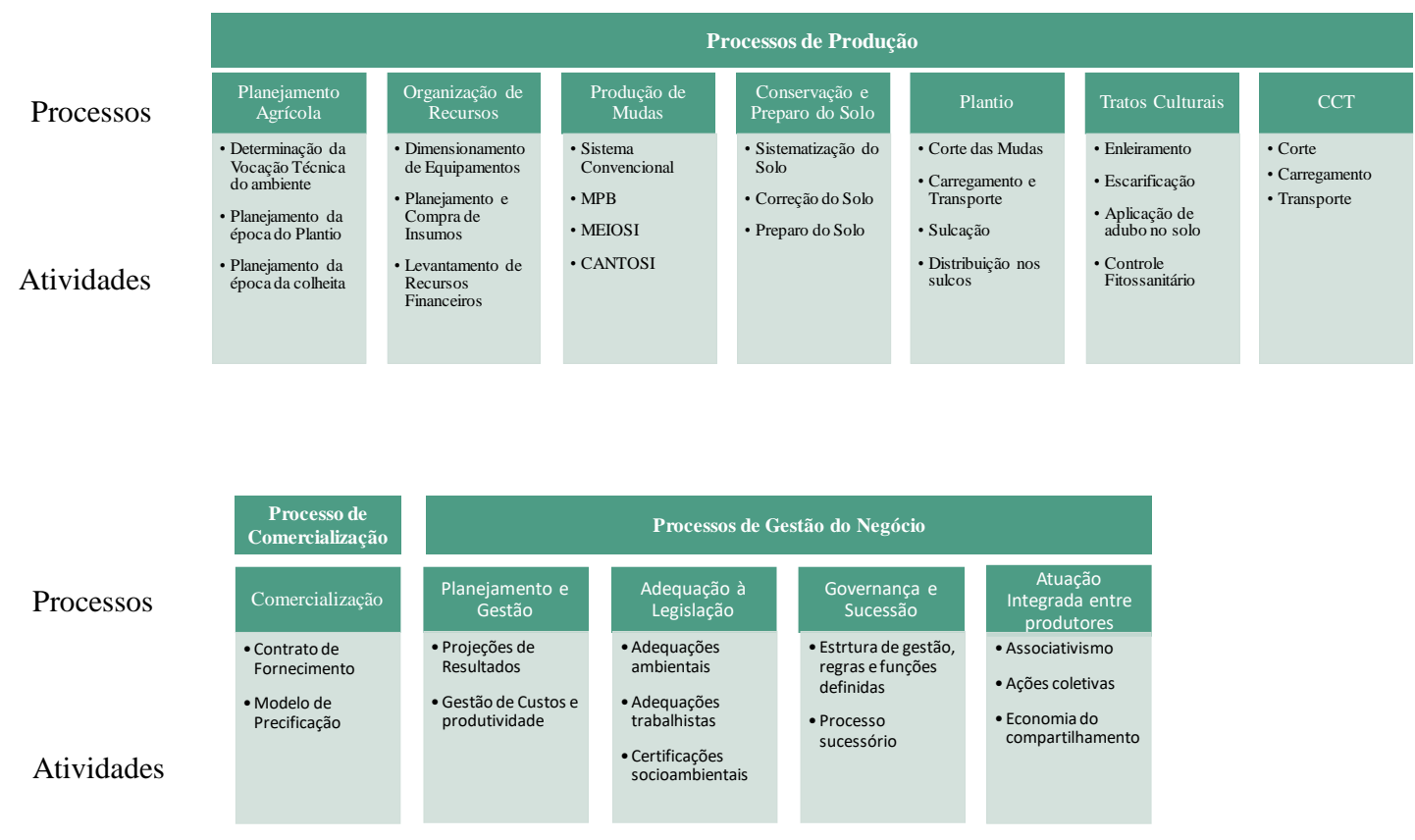

- Durante o processo quais são os principais desafios?

- Quais métodos você utiliza?

- Você conta com o apoio de algum serviço, produto ou tecnologia para realizar estas atividades?

- Em que pontos você considera que suas necessidades não são atendidas? E em quais pontos você está satisfeito?

Observação: Com o intuito de capturar o que é mais relevante para produtor, a pergunta 1 é aberta. À medida que a conversa transcorre, o pesquisador buscará capturar os aspectos levantados nas demais perguntas. Caso o entrevistado não mencione alguma das atividades mapeadas ou algum dos aspectos previstos no roteiro, o pesquisador irá realizar os questionamentos. 
P

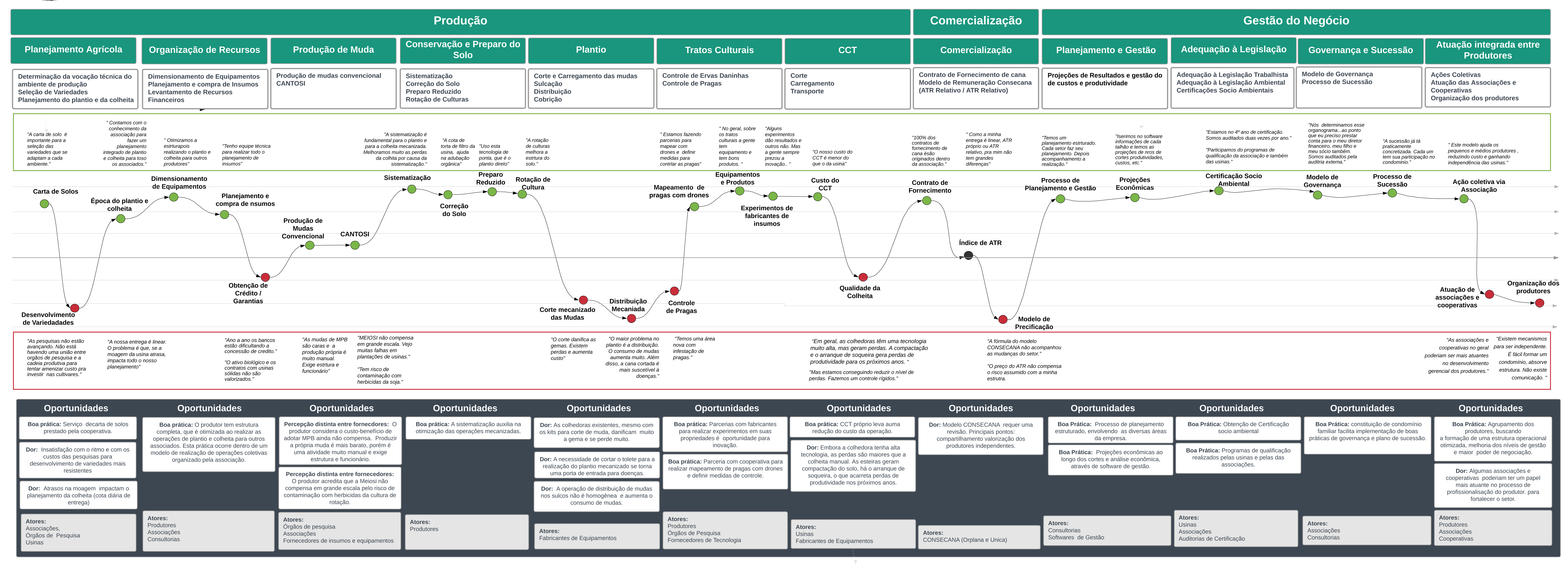


Persona: RICARDO SOARES / Produtor Intermediário/Grande

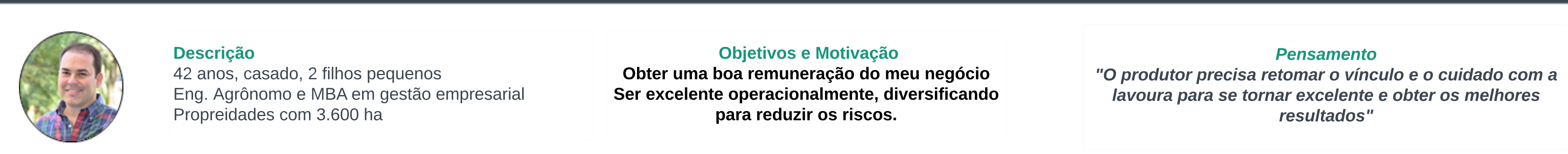

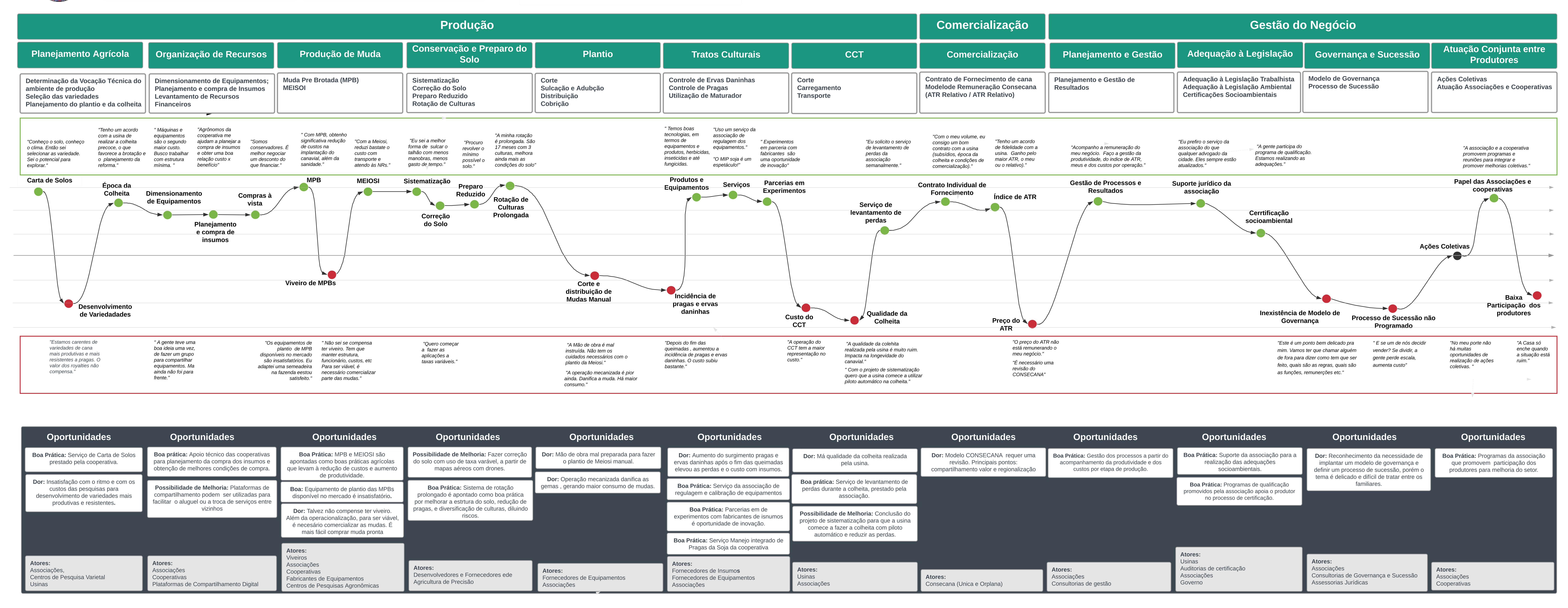




\section{FIGURA 23 - MAPA DA EXPERIÊNCIA DOS PRODUTORES DE CANA-DE AÇÚCAR Lairsa Mayer Munthos I May 21, 2019}

Persona: Antônio Moraes / Produtor Báico / Pequeno

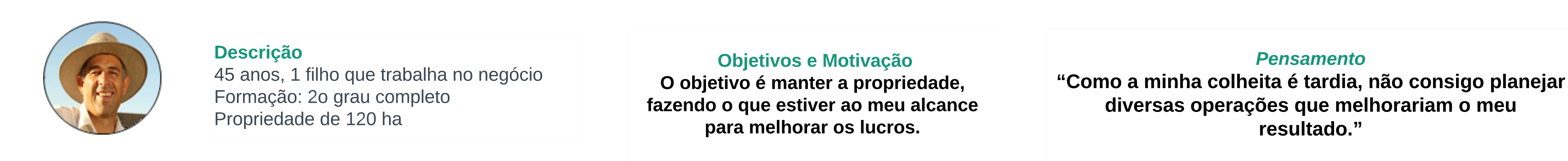

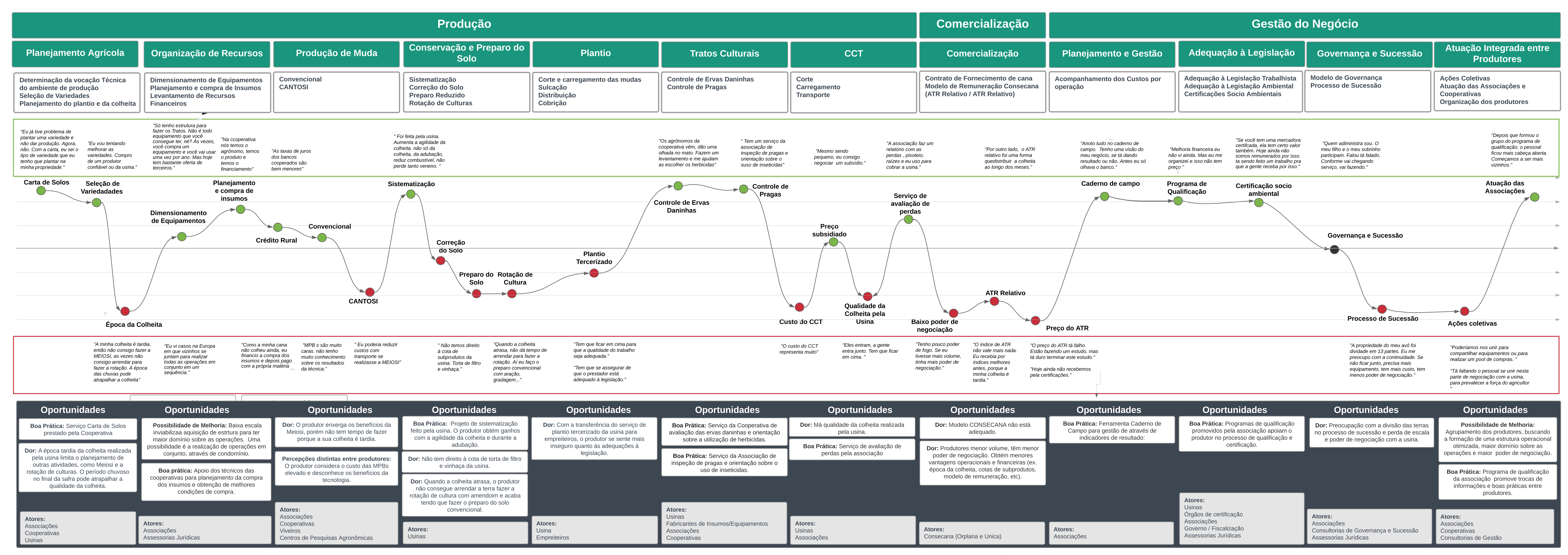


Comparação das Experiências entre as Três Personas
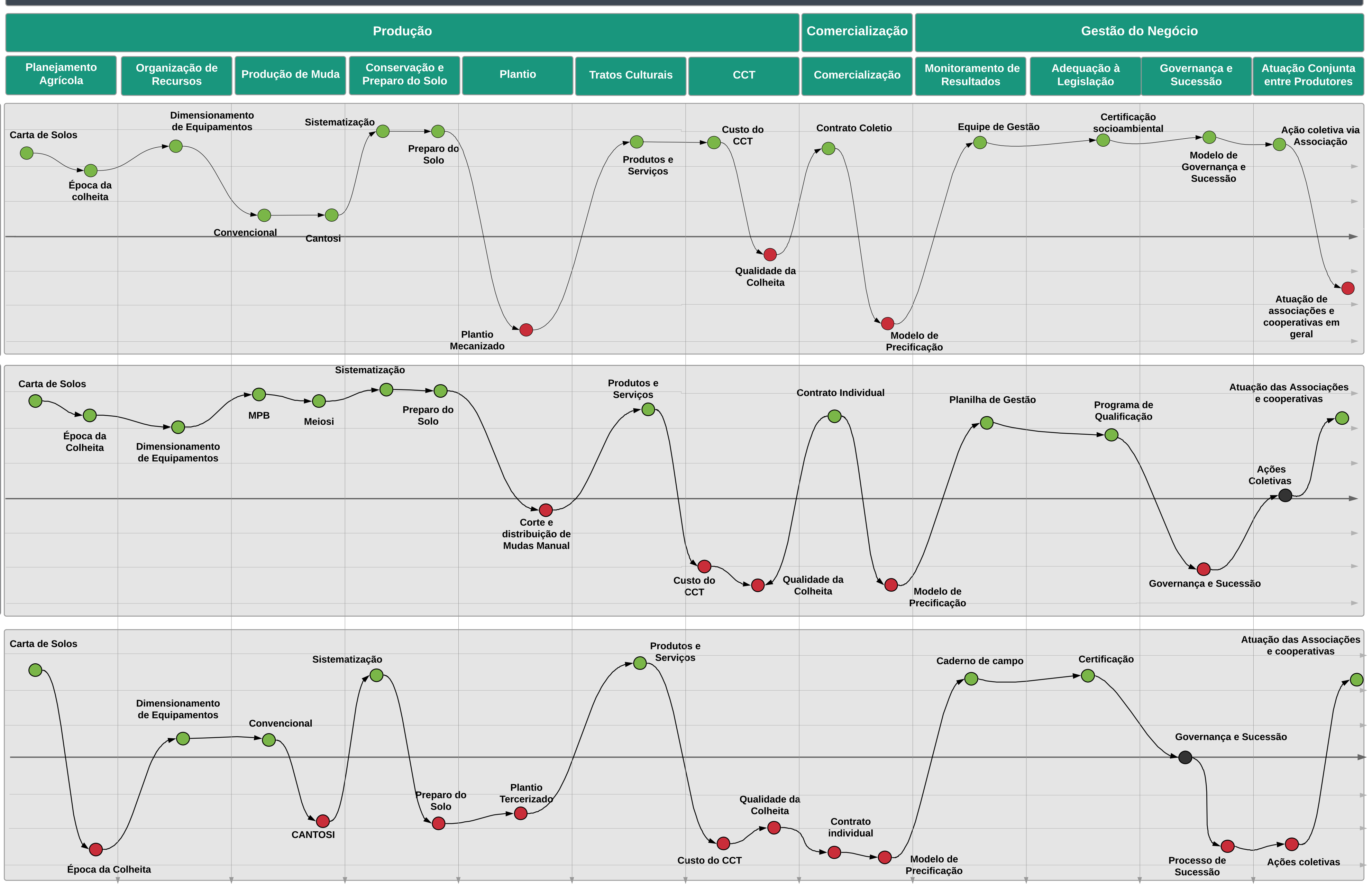